\title{
LABORATORY AND FIELD-BASED INVESTIGATIONS OF SUBSURFACE GEOCHEMICAL PROCESSES IN SEAFLOOR HYDROTHERMAL SYSTEMS
}

\author{
By \\ Eoghan Reeves \\ B.Sc., University of Wales, Bangor, 2002 \\ M.Sc., University of Leeds, 2004 \\ Submitted in partial fulfillment of the requirements for the degree of \\ Doctor of Philosophy \\ at the \\ MASSACHUSETTS INSTITUTE OF TECHNOLOGY \\ and the
}

WOODS HOLE OCEANOGRAPHIC INSTITUTION

June 2010

(C) 2010 Eoghan Reeves

All rights reserved.

The author hereby grants to MIT and WHOI permission to reproduce and to distribute publicly paper and electronic copies of this thesis document in whole or in part in any medium now known or hereafter created.

Signature of Author

Joint Program in Oceanography/Applied Ocean Science and Engineering Massachusetts Institute of Technology and Woods Hole Oceanographic Institution April 2 ${ }^{\text {nd }}, 2010$

Certified by

Dr. Jeffrey S. Seewald Thesis Supervisor

Accepted by

Prof. Roger Summons

Chair, Joint Committee for Chemical Oceanography Massachusetts Institute of Technology 


\title{
LABORATORY AND FIELD-BASED INVESTIGATIONS OF SUBSURFACE GEOCHEMICAL Processes in SEAFloor Hydrothermal SySTEMS
}

\author{
by \\ Eoghan Reeves \\ Submitted on April 2 ${ }^{\text {nd }}, 2010$, to the MIT/WHOI Joint Program in Oceanography and Applied \\ Ocean Science and Engineering in partial fulfillment of the requirements for the degree of Doctor \\ of Philosophy in the field of Chemical Oceanography
}

\section{THESIS ABSTRACT}

This thesis presents the results of four discrete investigations into processes governing the organic and inorganic chemical composition of seafloor hydrothermal fluids in a variety of geologic settings. Though Chapters 2 through 5 of this thesis are disparate in focus, each represents a novel investigation aimed at furthering our understanding of subsurface geochemical processes affecting hydrothermal fluid compositions. Chapters 2 and 3 concern the abiotic (nonbiological) formation of organic compounds in high temperature vent fluids, a process which has direct implications for the emergence of life in early Earth settings and sustainment of present day microbial populations in hydrothermal environments. Chapter 2 represents an experimental investigation of methane $\left(\mathrm{CH}_{4}\right)$ formation under hydrothermal conditions. The overall reduction of carbon dioxide $\left(\mathrm{CO}_{2}\right)$ to $\mathrm{CH}_{4}$, previously assumed to be kinetically inhibited in the absence of mineral catalysts, is shown to proceed on timescales pertinent to crustal residence times of hydrothermal fluids. In Chapter 3, the abundance of methanethiol $\left(\mathrm{CH}_{3} \mathrm{SH}\right)$, considered to be a crucial precursor for the emergence of primitive chemoautotrophic life, is characterized in vent fluids from ultramafic-, basalt- and sediment-hosted hydrothermal systems. Previous assumptions that $\mathrm{CH}_{3} \mathrm{SH}$ forms by reduction of $\mathrm{CO}_{2}$ are not supported by the observed distribution in natural systems. Chapter 4 investigates factors regulating the hydrogen isotope composition of hydrocarbons under hydrothermal conditions. Isotopic exchange between low molecular weight $n$-alkanes and water is shown to be facilitated by metastable equilibrium reactions between alkanes and their corresponding alkenes, which are feasible in natural systems. In Chapter 5, the controls on vent fluid composition in a backarc hydrothermal system are investigated. A comprehensive survey of the inorganic geochemistry of fluids from sites of hydrothermal activity in the eastern Manus Basin indicates that fluids there are influenced by input of acidic magmatic solutions at depth, and subsequently modified by variable extents of seawater entrainment and mixing-related secondary acidity production.

Thesis Supervisor: Dr. Jeffrey S. Seewald

Title: Senior Scientist, Woods Hole Oceanographic Institution 


\section{ACKNOWLEDGEMENTS}

First and foremost, I would like to thank my advisor, Jeff Seewald, for the past 5+ years of guidance throughout my graduate education and research. Jeff's limitless optimism and scientific imagination have been inspirational and I have thoroughly enjoyed and benefited from being part of his lab group. His infectious positive attitude and constant disbelief at my occasional worries have left an indelible mark on my professional and personal attitudes. I would also like to express my sincerest thanks to Meg Tivey, for her continual support, guidance and advice on all aspects of my life in the Joint Program. My committee members Tom McCollom and Phil Gschwend have been an integral part of making this thesis what it is and I thank them for their feedback, questions and genuine interest in my research.

My research would not have been successful without many persons at WHOI and elsewhere who provided invaluable assistance. Firstly, I would like to thank Sean Sylva (and Sebastion the Dog) for unfailingly answering my countless technical questions or pointing me in the direction of answers (or in the case of Sebastion just staring blankly at me until I figured it out), and for conducting isotopic analyses in several of the chapters in this thesis. My research and life here have also benefited greatly from help and conversations with Giora Proskurowski, for which thanks are due. Numerous others were of assistance on the various cruises for which data was collected: A.L. Reysenbach, W.E. Seyfried, N. Pester, M. Rough, S. Sievert, P. Saccocia, E. Walsh, M. Wert and T. Nielson. Collaborators who kindly provided some of the data included in Chapter 5 include Wolfgang Bach, Paul Craddock, Wayne C. Shanks, Thomas Pichler and Martin Rosner. Thanks are also due to Alex Sessions for assistance with water isotope analysis for Chapter 4. Many thanks are also due to the Academic Programs Office staff members who constantly endeavor to keep the Joint Program running smoothly - Marsha Gomes, Julia Westwater, Christine Charette, Jim Yoder and Jim Price. Thanks also to Ronni Schwartz and Mary Elliff at MIT. Sheila Clifford, Donna Mortimer and the MC\&G administrative staff have always provided help and service when needed with a smile and are greatly appreciated.

I must express my deepest thanks and love for my family, especially my mother Margaret Reeves, as well as my little sister Clare, my brothers Tadhg and Niall, and my grandmother 'Lil' who sadly did not live to see me defend my thesis. To my mum, thank you for always believing in me and supporting me unconditionally, right from the start, even though you never fully understood this unusual road I chose to take many years ago. You and Lil always stated that each generation of a family should have even richer opportunities than the last, and your hard work and sacrifice have shown that and helped me to get where I am today. I will never forget that.

My life in the Joint Program, in addition to being professionally fulfilling, has been enriched by the many great friendships I have made here since I started. To my many past and present housemates who double as great friends, Joanna Gyory, Frieder Klein, Christian Miller, Tyler Goepfert, Emily Peacock, Nick Drenzek, Louisa Morrison, Casey Saenger and Mike Brosnahan, thanks for the laughs, dinners, parties and happy times. To my incredibly supportive friends who helped through to the end of this with style: Laura Hmelo, Taylor Crockford, Emilia DeForce, Michelle Bringer, Justin Ossolinski, Louie Wurch, John Ahern, Frieder \& Joanna, J.B.: thank you for so many things. I would also like to thank the many others who have been a part of my life here over the years: Stephanie Owens, Breea Govenar, Erin Bertrand, Carly Buchwald, Caitlin Frame, Alysia Cox, Jeff Kaeli, Maya Yamato, Erin Banning and Travis Poole. 
The thesis research presented here was funded by the National Science Foundation through grants OCE-0327448, OCE-0136954, MCB-0702677, OCE-0549829, and by the Department of Energy grant DE-FG02-97ER14746. Funding was also provided by the WHOI Deep Ocean Exploration Institute Graduate Fellowship, as well by the WHOI Academic Programs Office. 


\section{TABLE OF CONTENTS}

ABSTRACT

ACKNOWLEDGEMENTS

TABLE OF CONTENTS

LIST OF FIGURES

CHAPTER 1. INTRODUCTION

CHAPTER 2. EXPERIMENTAL INVESTIGATION OF $\mathrm{CO}_{2}$ REDUCTION TO $\mathrm{CH}_{4}$ UNDER HYDROTHERMAL CONDITIONS 23

1. Introduction 25

2. Methods $\quad 29$

2.1. Experimental Apparatus and Design 29

2.2. Analysis of Dissolved Species 31

3. Results

3.1. $\mathrm{CO}_{2}$ and $\mathrm{H}_{2}$

3.2. $\mathrm{CH}_{4}$ and $\mathrm{CH}_{3} \mathrm{OH}$ formation $\quad 34$

3.3. Other C species $\quad 35$

3.4. S-bearing species $\quad 35$

4. Discussion $\quad 37$

4.1. Thermodynamic constraints on metastable equilibrium 39

4.2. The relative roles of $\mathrm{CH}_{3} \mathrm{OH}$ and $\mathrm{CH}_{3} \mathrm{SH}$ in abiotic synthesis of $\mathrm{CH}_{4} 41$

4.3. Implications for hydrothermal systems 41

4.3.1 $\mathrm{CH}_{3} \mathrm{OH}$ and $\mathrm{CH}_{4}$ formation $\quad 41$

4.3.2 $\mathrm{CH}_{3} \mathrm{SH}$ formation $\quad 44$

5. Conclusions 45

CHAPTER 3. INSIGHTS INTO THE ORIGIN OF METHANETHIOL IN SEAFLOOR HYDROTHERMAL FLUIDS $\quad 67$

1. Introduction 68

2. Methods $\quad 70$

3. Results $\quad 72$

5. Discussion $\quad 73$

4. Conclusions $\quad 79$

CHAPTER 4. RAPID HYDROGEN ISOTOPE $\left({ }^{2} \mathrm{H} /{ }^{1} \mathrm{H}\right)$ EXCHANGE BETWEEN AQUEOUS $N$-ALKANES AND WATER UNDER HYDROTHERMAL CONDITIONS: IMPLICATIONS FOR THE ISOTOPIC COMPOSITION OF ABIOGENIC AND THERMOGENIC HYDROCARBONS 93

1. Introduction 95

2. Materials and Methods $\quad 98$

2.1 Experimental Approach and Setup 98 
2.2 Analytical Methods $\quad 101$

3. Results 105

$3.1{ }^{2} \mathrm{H} /{ }^{1} \mathrm{H}$ ratios $\quad 105$

3.2 Dissolved species concentrations $\quad 106$

3.2.1 $\mathrm{H}_{2}$ and $\mathrm{H}_{2} \mathrm{~S}$ concentrations 106

3.2.2 Dissolved hydrocarbon concentrations 106

3.2.3 $\mathrm{\Sigma CO}_{2}$ and organic acid concentrations 107

$\begin{array}{ll}\text { 4. Discussion } & 109\end{array}$

4.1 Alkane-alkene equilibria 109

4.2 Reversible ${ }^{2} \mathrm{H} /{ }^{1} \mathrm{H}$ exchange and isotopic equilibrium 110

4.2.1 Alkane-alkene equilibrium and ${ }^{2} \mathrm{H} /{ }^{1} \mathrm{H}$ exchange $\quad 110$

4.2.2 Isotopic equilibrium and alkane $\delta^{2} \mathrm{H}$ trends $\quad 113$

$\begin{array}{ll}\text { 4.2.3 Variations in } \delta^{2} \mathrm{H}_{\text {meth }} & 115\end{array}$

4.3 Implications for natural systems $\quad 116$

4.3.1 ${ }^{2} \mathrm{H} /{ }^{1} \mathrm{H}$ ratios and abiogenesis in igneous environments 116

4.3.2 ${ }^{2} \mathrm{H} /{ }^{1} \mathrm{H}$ signatures in thermogenic hydrocarbons 121

5. Conclusions

CHAPTER 5. GEOCHEMISTRY OF HYDROTHERMAL FLUIDS FROM THE PACMANUS,

NORTHEAST PUAL AND VIENNA WOODS VENT FIELDS, MANUS BASIN,

PAPUA NEW GUINEA 151

1. Introduction 154

2. Geological Setting 157

2.1 Hydrothermal Vent Fields 158

2.1.1 Vienna Woods 158

2.1.2 PACMANUS and Northeast Pual 158

3. Methods 161

3.1 Sample collection $\quad 161$

3.2 Analytical methods $\quad 162$

3.3 Calculation of endmember compositions 164

4. Results

4.1 Temperature 167

$\begin{array}{ll}4.2 \mathrm{Mg} \text { and } \mathrm{SO}_{4} & 168\end{array}$

$\begin{array}{ll}4.3 \mathrm{pH} & 169\end{array}$

4.4 $\mathrm{H}_{2}, \mathrm{H}_{2} \mathrm{~S}, \mathrm{CH}_{4}, \mathrm{CO}$ and $\mathrm{CO}_{2} \quad 169$

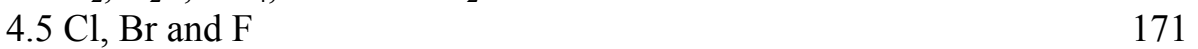

$4.6 \delta^{18} \mathrm{O}_{\mathrm{H} 2 \mathrm{O}}$ and $\delta \mathrm{D}_{\mathrm{H} 2 \mathrm{O}} \quad 172$

4.7 Alkalis, alkaline earths and B 172

$\begin{array}{ll}4.8 \mathrm{Fe}, \mathrm{Mn}, \mathrm{Al} \text { and } \mathrm{SiO}_{2} & 174\end{array}$

$\begin{array}{ll}\text { 5. Discussion } & 175\end{array}$

5.1 Influence of water/rock reaction and substrate composition

$\begin{array}{ll}\text { 5.1.1 Fluid-mineral equilibria } & 176\end{array}$

5.1.2 Alkalis and B $\quad 179$

5.1.3 Quartz-fluid equilibrium and dissolved $\mathrm{SiO}_{2} \quad 181$

$5.1 .4 \mathrm{pH}$ and metal mobility $\quad 182$

$\begin{array}{ll}\text { 5.2 Phase separation and Cl variability } & 184\end{array}$ 
$\begin{array}{ll}\text { 5.3 Magmatic fluid input at Pual Ridge } & 187\end{array}$

5.3.1 Isotopic evidence for magmatic $\mathrm{H}_{2} \mathrm{O} \quad 187$

5.3.2 Magmatic $\mathrm{CO}_{2}, \mathrm{~F}$, and $\mathrm{Cl} \quad 191$

5.3.3 Magmatic $\mathrm{SO}_{2}$ input and disproportionation $\quad 194$

5.3.4 Spatial variability of magmatic fluid inputs 197

$\begin{array}{ll}5.4 \text { Subsurface seawater entrainment } & 198\end{array}$

5.4.1 Secondary Acidity 202

6. Summary 205

CHAPTER 6. COMMENTS AND FUTURE RESEARCH DIRECTIONS

271 


\section{LiST OF TABLES}

\section{CHAPTER 2.}

2.1. Concentrations of aqueous species measured during heating of $\mathrm{HCOOH}$ at $325-300^{\circ} \mathrm{C}$ and $35 \mathrm{MPa}$

2.2. Predicted concentrations of methanol in equilibrium with measured $\mathrm{CO}_{2}$ and $\mathrm{H}_{2}$ for two representative fluids from high temperature ultramafic-hosted hydrothermal systems

CHAPTER 3.

3.1. Measured concentrations of $\mathrm{Mg}$ and dissolved gases in vent fluids

3.2. Endmember concentrations of $\mathrm{CH}_{3} \mathrm{SH}, \mathrm{H}_{2}, \mathrm{H}_{2} \mathrm{~S}, \Sigma \mathrm{CO}_{2}, \mathrm{CO}$ and $\mathrm{CH}_{4}$

\section{ChaPter 4.}

4.1. Concentrations of aqueous species during heating of $\mathrm{C} 1$ to $\mathrm{C} 5 n$-alkane mixtures at $323^{\circ} \mathrm{C}$ and $35 \mathrm{MPa}$ with a pyrite-pyrrhotite-magnetite (PPM) mineral assemblage

4.2. Hydrogen isotope compositions of dissolved C1 to C5 $n$-alkanes and corresponding solutions during heating with a pyrite-pyrrhotite-magnetite (PPM) mineral assemblage

\section{CHAPTER 5.}

5.1. Measured compositions of vent fluid samples from the Vienna Woods, PACMANUS and NE Pual vent fields, Manus Basin

5.2. Summary of vent fluid compositions extrapolated to zero $\mathrm{Mg}$ concentration from the Vienna Woods, PACMANUS and NE Pual vent fields, Manus Basin

5.3. Selected elemental ratios at zero $\mathrm{Mg}$ concentration from the Vienna Woods, PACMANUS and NE Pual vent fields, Manus Basin 


\section{LiST OF FiguRES}

\section{ChAPTer 2.}

2.1. Model for the sequential aqueous reduction of $\mathrm{CO}_{2}$ to $\mathrm{CH}_{4}$ by $\mathrm{H}_{2}$ via a series of intermediate oxidation state single carbon compounds

2.2. Temperature dependence of the equilibrium constants $\left(K_{e q}\right)$ for $\mathrm{CH}_{3} \mathrm{OH}$, $\mathrm{CH}_{3} \mathrm{SH}$ and $\mathrm{CH}_{4}$ formation by overall $\mathrm{CO}_{2}$ reduction

2.3. Schematic of the SEYFRIED (1987) design of flexible-cell

hydrothermal reactor and pressure containment vessel

2.4. Measured concentrations of dissolved species as a function of time during the $325^{\circ} \mathrm{C}$ and $300^{\circ} \mathrm{C}$ phases of the experiment

2.5. Mass spectrum of normal ${ }^{13} \mathrm{C}$ abundance $\mathrm{CH}_{3} \mathrm{OH}, \mathrm{CH}_{3} \mathrm{SH}$ and $\mathrm{CH}_{4}$ standards compared with ${ }^{13} \mathrm{C}$-labeled forms in experimental samples

2.6. Thermodynamic affinities for the production of $\mathrm{CH}_{3} \mathrm{OH}\left(A_{\text {Methanol }}\right)$ and $\mathrm{CH}_{4}\left(A_{\text {Methane }}\right)$ by the overall reactions shown in Figure 2.2 during the experiment

2.7. Equilibrium abundances of aqueous species as a function of $\mathrm{pH}$ at $35 \mathrm{MPa}$ for model solutions

\section{CHAPTER 3.}

3.1. Equilibrium constants $\left(\log \mathrm{K}_{\mathrm{eq}}\right.$ ) for the formation of $\mathrm{CH}_{3} \mathrm{SH}$ from either $\mathrm{CO}_{2}$ (reduction) or $\mathrm{CH}_{4}$ (oxidation) as a function of temperature at 300 bar 83

3.2. Predicted concentration (open symbols) of $\mathrm{CH}_{3} \mathrm{SH}$ according to reaction (1) and reaction (2) as a function of measured $\mathrm{H}_{2}$ concentrations

\section{Chapter 4.}

4.1. Activity diagram showing the phase relations in the system $\mathrm{Fe}-\mathrm{S}-\mathrm{O}-\mathrm{H}$ at $325^{\circ} \mathrm{C}$ and $35 \mathrm{MPa}$

4.2. $\mathrm{C}_{1}$ to $\mathrm{C}_{5} n$-alkane $\delta^{2} \mathrm{H}$ values from Experiment 1 and Experiment 2 as a function of time at $323^{\circ} \mathrm{C}$ and $35 \mathrm{MPa}$

4.3. Concentrations of $\mathrm{C}_{1}$ to $\mathrm{C}_{5} n$-alkanes and $\Sigma \mathrm{CO}_{2}$ from Experiment 1 and Experiment 2 as a function of time at $323^{\circ} \mathrm{C}$ and $35 \mathrm{MPa}$

4.4. Concentrations of $\mathrm{C}_{2}, \mathrm{C}_{3}$ and $\mathrm{C}_{5} n$-alkenes in Experiment 1 and Experiment 2 as a function of time at $323^{\circ} \mathrm{C}$ and $35 \mathrm{MPa}$

4.5. Chemical affinities for oxidation of $\mathrm{C}_{2}, \mathrm{C}_{3}$ and $\mathrm{C}_{5} n$-alkanes to their corresponding terminal $n$-alkenes as a function of time at $323^{\circ} \mathrm{C}$ and $35 \mathrm{MPa}$ in Experiment 1 and Experiment 2

4.6. Proposed mechanism for the reversible equilibration of $n$-pentane with individual pentene isomers allowing exchange of all $\mathrm{H}$ atoms at each carbon position (*) throughout the molecule 136

4.7. Equilibrium constants $\left(K_{e q}\right)$ for reactions between $\mathrm{C}_{2}$ to $\mathrm{C}_{5} n$-alkenes and their corresponding terminal $n$-alkenes as a function of temperature

4.8. Isotopograms showing the $\delta^{2} \mathrm{H}$ values of $n$-alkanes as a function of chain length for the Kidd Creek Mine abiogenic gases, thermogenic gases from Southwest Ontario gas fields, Lost City vent fluidsand alkanes produced by experiment aqueous Fischer-Tropsch-type (FTT) synthesis at $400^{\circ} \mathrm{C}$ 
4.9. Plot of theoretical alkane-water equilibrium fractionation factors for ethane $\left(\alpha_{\text {ethane/w }}\right)$, propane $\left(\alpha_{\text {propane/w }}\right), n$-butane $\left(\alpha_{\text {butane/w }}\right)$ and $n$-pentane $\left(\alpha_{\text {pentane/w }}\right) \mathrm{H}$

calculated as a function of temperature

\section{CHAPTER 5.}

5.1. Regional map showing the Manus Basin (eastern Bismarck Sea) and SeaBeam map of bathymetric map of Pual Ridge and nearby Marmin Knolls neovolcanic edifices

5.2. SM2000 bathymetry of the Vienna Woods hydrothermal field and the northern and southern portions of the PACMANUS hydrothermal field

5.3. Plot of vent pressures and maximum temperatures $\left(\mathrm{T}_{\max }\right)$ for all moderate- to high-temperature fluids sampled at Vienna Woods and PACMANUS 217

5.4. Measured $\mathrm{SO}_{4}$ concentrations $v s$. measured $\mathrm{Mg}$ for all vent fluid samples from the Vienna Woods, PACMANUS and NE Pual fields

5.5. Endmember $\mathrm{H}_{2}, \Sigma \mathrm{CO}_{2}, \mathrm{H}_{2} \mathrm{~S}$ and $\mathrm{CH}_{4}$ concentrations vs. endmember $\mathrm{Cl}$ concentrations for all PACMANUS, NE Pual and Vienna Woods fluids 221

5.6. $\quad$ Endmember $\Sigma \mathrm{CO}_{2}$ concentrations vs. endmember $\mathrm{F}$ concentration for all PACMANUS, NE Pual and Vienna Woods fluids

5.7. Endmember $\delta \mathrm{D}_{\mathrm{H} 2 \mathrm{O}}$ and $\delta^{18} \mathrm{O}_{\mathrm{H} 2 \mathrm{O}}$ values from Vienna Woods and PACMANUS vent fields, with axes expanded to show compositions of mantle-derived water and subduction-related volcanic vapors 225

5.8. Measured ${ }^{87} \mathrm{Sr} /{ }^{86} \mathrm{Sr}$ ratios versus measured $\mathrm{Mg} / \mathrm{Sr}$ ratios for select Vienna Woods and PACMANUS fluids

5.9. Endmember $\mathrm{K}, \mathrm{Li}$ and $\mathrm{Cs}$ concentrations $v s$. endmember $\mathrm{Rb}$ concentration for Vienna Woods, PACMANUS and NE Pual fluids 229

5.10. Endmember $\mathrm{SiO}_{2}$ concentrations and extrapolated vent temperatures for Vienna Woods and PACMANUS fluids 231

5.11. Endmember $\mathrm{Li}, \mathrm{Rb}, \mathrm{K}$ and $\mathrm{Cs}$ concentrations vs. corresponding endmember $\mathrm{Cl}$ concentration for Vienna Woods, PACMANUS and NE Pual vent fluids 233

5.12. $\delta^{34} \mathrm{~S}$ values for dissolved $\mathrm{H}_{2} \mathrm{~S}\left(\delta^{34} \mathrm{~S}_{\mathrm{H} 2 \mathrm{~S}}\right)$ versus endmember $\Sigma \mathrm{CO}_{2}$ Concentrations

5.13. Maximum measured vent temperatures $\left(\mathrm{T}_{\max }\right)$ for co-located vent fluids at Roman Ruins and Fenway versus their lowest measured $\mathrm{Mg}$ concentrations $\left(\mathrm{Mg}_{\min }\right)$

5.14. Plots of endmember $\mathrm{Ca} / \mathrm{Cl}$ ratios, endmember $\mathrm{Sr} / \mathrm{Cl}$ ratios, lowest measured fluid $\mathrm{pH}\left(25^{\circ} \mathrm{C}\right)$ and endmember $\mathrm{Fe} / \mathrm{Mn}$ ratios from Vienna Woods and Pual Ridge vent fluids vs. the lowest measured $\mathrm{Mg}$ concentration $\left(\mathrm{Mg}_{\min }\right)$ for each fluid 239

5.15. Plot of measured molar $\mathrm{Ca} / \mathrm{Cl}$ ratios ("in situ") and corresponding "corrected" values (adjusted for anhydrite precipitation) versus lowest measured $\mathrm{Mg}$ concentrations $\left(\mathrm{Mg}_{\min }\right)$ for closely co-located PACMANUS vent fluids

\section{CHAPTER 6.}

6.1 Cartoon showing major processes influencing the evolution of fluid compositions in back-arc hydrothermal systems 


\section{CHAPTER 1}

\section{Introduction}

Seafloor hydrothermal systems associated with the generation of oceanic crust represent a dramatic expression of heat and mass transfer from the interior of the Earth. In addition to profound effects on ocean chemistry, convective circulation of seawater through volcanically active oceanic crust leads to the formation of metal sulfide deposits. In addition, seafloor hot springs are often invoked as ideal settings from which early microbial life could have emerged. Since the initial discovery of low temperature venting at the Galápagos Spreading Center in 1977 (CORLISS et al., 1979), our understanding of the composition and diversity of hydrothermal solutions has expanded greatly. During convection through oceanic crust of basaltic composition, $\mathrm{O}_{2}$-replete seawater reacts with crustal rock, typically producing hot, reducing, acidic and metalrich solutions that are depleted in $\mathrm{Mg}$ and $\mathrm{SO}_{4}$ and variably enriched or depleted in $\mathrm{Cl}$ (BUTTERFIELD et al., 2003). In hydrothermal systems where alteration of ultramafic rock (serpentinization) is occurring, such as Rainbow (CHARLOU et al., 2002) and Lost City (KELLEY et al., 2001; KELLEY et al., 2005), more $\mathrm{H}_{2}$-rich solutions are produced as a result of the oxidation of the ferrous iron component of olivine. Depending on the conditions of water-rock interaction either acidic or alkaline fluids can be produced in these systems (KLEIN et al., 2009; MCCOLLOM and $\mathrm{BACH}, 2009$ ). Our understanding of key geochemical parameters such as fluid redox and $\mathrm{pH}$, and the mobility and behavior of metals in hydrothermal solutions has also advanced (e.g. SEyFrIED, 1987; SEEWALD and SEYFried, 1990; SEYFRIED and DiNG, 1995; TIVEY et al., 1995; Allen and Seyfried, 2003; CrAdDOCK, 2008; Klein et al., 2009; MCCOllom and BaCH, 2009). While these inorganic aspects of vent fluid geochemistry are reasonably well constrained, 
what is less well understood is the formation and transformation of carbon species in hydrothermal solutions, especially in ultramafic geologic settings where highly reducing fluids contain high concentrations of $\mathrm{CH}_{4}$ and other hydrocarbons of purported non-biological (abiotic) origin (Holm and Charlou, 2001; Charlou et al., 2002; MCCollom and SeEwald, 2007; PROSKUROWSKI et al., 2008; KONN et al., 2009). In addition, though water-rock interactions in backarc environments may broadly resemble those of basalt-hosted systems in some respects (BUTTERFIELD et al., 2003), our understanding of the role of acidic magma-derived solutions in influencing hydrothermal fluid chemistry in these environments is currently limited by a lack of comprehensive geochemical investigations (GAMO et al., 2006; YANG and ScOTT, 2006). This thesis presents a series of independent studies addressing these two emergent areas of inquiry in the geochemistry of hydrothermal solutions.

The origin of reduced carbon compounds in seafloor hydrothermal fluids is currently a subject of considerable interest (MCCOLlOM and SEEWALD, 2007; PROSKUROWSKI et al., 2008; KONN et al., 2009). Since the discovery of seafloor hot springs, hydrothermal systems have been discussed as a plausible setting for the emergence of early life on Earth (CORLISS et al., 1981) and the potential for synthesis of prebiotic organic compounds in hydrothermal solutions figures prominently in arguments for a hyperthermophilic hydrothermal origin of life (HOLM, 1992). However, our understanding of the role hydrothermal systems may have played in providing the key prebiotic compounds for the emergence of life is still largely speculative. The expansion in recent decades of theoretical organic geochemistry has illustrated that thermodynamic drives may exist for the formation of a variety of organic species during hydrothermal circulation through the oceanic crust (SHOCK, 1990, 1992; SHOCK and SCHULTE, 1998) but several aspects of carbon transformations and organic syntheses in hydrothermal systems are poorly understood. Experimental investigations of organic synthesis under realistic hydrothermal conditions have 
largely focused on hydrocarbon formation by mineral catalysis (FOUSTOUKOS and SEYFRIED, 2004; McCollom and Seewald, 2006; Fu et al., 2007). However, hydrocarbon formation in the absence of catalytic minerals has largely been ignored. Chapter 2 of this thesis specifically addresses the possibility of aqueous $\mathrm{CH}_{4}$ formation via intermediate oxidation state carbon compounds, thereby challenging previously held assumptions that $\mathrm{CO}_{2}$ reduction without mineral catalysis is kinetically inhibited.

While the synthesis of aliphatic hydrocarbon components is an important prerequisite for the formation of any primitive cellular structures, other organic functional groups are clearly required for early life to emerge in a hydrothermal setting. Theories postulating that primitive chemoautotrophism emerged as the earliest form of life all invoke an abiotic supply of methanethiol $\left(\mathrm{CH}_{3} \mathrm{SH}\right)$ for the synthesis of thioester - the functional group involved in metabolism (DE DuVe, 1991; Huber and Wachtershauser, 1997; MARTIN and Russell, 2006; RUSSELL and HALL, 2006). Chapter 3 represents the first known survey of the distribution of $\mathrm{CH}_{3} \mathrm{SH}$ in present day vent fluids and discusses possible origins.

The use of stable isotope measurements has become an important tool in elucidating processes of abiotic hydrocarbon production (SHERWOOD LOLLAR et al., 2002; PROSKUROWSKI et al., 2008). Chapter 4 represents an experimental investigation of the feasibility of hydrogen isotope exchange between low molecular weight hydrocarbons and water and the findings of this chapter have important implications for the utility of hydrogen isotopes in elucidating abiotic hydrocarbon production, in addition to contributing to our understanding of factors influencing the hydrogen isotope composition of hydrocarbons in petroleum systems.

While the Chapters 2 through 4 deal predominantly with carbon transformations in hydrothermal solutions, Chapter 5 deviates from this theme and presents a detailed survey of the chemistry of hydrothermal fluids from a felsic-hosted hydrothermal system in a backarc 
environment. Backarc spreading centers (those formed behind volcanic arcs associated with subduction zones) are known to host a large fraction ( 20\%) of hydrothermal systems discovered to date (ISHIBASHI and URABE, 1995) yet the chemistry of fluids in these systems still remains poorly characterized. Backarc hydrothermal systems represent the closest modern analog to Kuroko-type volcanic-hosted massive sulfide ore deposits (FRANKLIN et al., 1981; HERZIG and HANNINGTON, 1995) and the role of magma-derived fluids in influencing crustal alteration and massive sulfide formation is currently of great interest (GAMO et al., 2006; YANG and SCOTT, 2006). The identification of magmatic signatures is therefore a major focus of Chapter 5 and this study provides useful insight into magmatic-hydrothermal processes in backarc settings. 


\section{REFERENCES}

ALLEN, D. E. and SEYFRIED, W. E. (2003) Compositional controls on vent fluids from ultramatichosted hydrothermal systems at mid-ocean ridges: An experimental study at $400^{\circ} \mathrm{C}, 500$ bars. Geochimica et Cosmochimica Acta 67(8), 1531-1542.

Butterfield, D., Seyfried, W. E., and Lilley, M. (2003) Composition and evolution of hydrothermal fluids. In: Dahlem Workshop Report: Energy and Mass Transfer in Marine Hydrothermal Systems, (Ed: P. E. Halbach, V. Tunnicliffe, and J. R. Hein), 89, Dahlem University Press. pp. 123-161.

Charlou, J. L., Donval, J. P., Fouquet, Y., Jean-Baptiste, P., and Holm, N. (2002) Geochemistry of high $\mathrm{H}_{2}$ and $\mathrm{CH}_{4}$ vent fluids issuing from ultramafic rocks at the Rainbow hydrothermal field (36²'N, MAR). Chemical Geology 191(4), 345-359.

CORLISS, J. B., DYMOND, J., GORDON, L. I., EDMOND, J. M., VON HERZEN, R. P., BALLARD, R. D., Green, K., Williams, D., Bainbridge, A., Crane, K. et al. (1979) Submarine thermal springs on the Galapagos Rift. Science 203, 1073-1083.

Corliss, J. B., BAross, J. A., and Hoffman, S. E. (1981) An hypothesis concerning the relationship between submarine hot springs and the origin of life on Earth. Oceanologica Acta 4(Supplement), 59-69.

CRADDOCK, P. R. (2008) Geochemical Tracers of Processes Affecting the Formation of Seafloor Hydrothermal Fluids and Deposits in the Manus Back-arc Basin. Ph.D. Thesis. MITWHOI Joint Program in Oceanography, MIT.

DE Duve, C. (1991) Blueprint for a Cell: The Nature and Origin of Life. N. Patterson.

Foustoukos, D. I. and SEYFRIED, W. E. (2004) Hydrocarbons in hydrothermal vent fluids: The role of chromium-bearing catalysts. Science 304(5673), 1002-1005. 
FrANKLIN, J., LYNDON, J. W., and SANGSTER, D. F. (1981) Volcanic-associated massive sulfide deposits. Economic Geology 75, 485-627.

Fu, Q., Sherwood Lollar, B., Horita, J., Lacrampe-Couloume, G., and Seyfried, W. (2007) Abiotic formation of hydrocarbons under hydrothermal conditions: Constraints from chemical and isotopic data. Geochimica et Cosmochimica Acta 71(8), 1982-1998.

Gamo, T., IshiBAshi, J., TsunOgai, U., OKAmura, K., and ChiBA, H. (2006) Unique geochemistry of submarine hydrothermal fluids from arc-back-arc settings of the Western Pacific. In: Back-Arc Spreading Systems: Geological, Biological, Chemical, and Physical Interactions, (Ed: D. M. Christie, C. R. Fisher, S.-M. Lee, and S. Givens), AGU Monograph, 166, American Geophysical Union. pp. 147-161.

Herzig, P. M. and Hannington, M. D. (1995) Polymetallic massive sulfides at the modern seafloor - a review. Ore Geology Reviews 10(2), 95-115.

HoLm, N. G. (1992) Marine Hydrothermal Systems and the Origin of Life: Report of SCOR Working Group 91. Reprinted from: Origins of Life and Evolution of the Biosphere, Vol. 22 (1-4), 1992. Springer.

Holm, N. G. and CHARLOU, J. L. (2001) Initial indications of abiotic formation of hydrocarbons in the Rainbow ultramafic hydrothermal system, Mid-Atlantic Ridge. Earth And Planetary Science Letters 191(1-2), 1-8.

Huber, C. and WACHTERShaUSER, G. (1997) Activated acetic acid by carbon fixation on (Fe,Ni)S under primordial conditions. Science 276(5310), 245-247.

ISHIBASHI, J. and URABE, T. (1995) Hydrothermal activity related to arc-backarc magmatism in the Western Pacific. In: Backarc Basins: Tectonics and Magmatism, (Ed: B. Taylor), Plenum Press. pp. 451-495. 
Kelley, D. S., Karson, J. A., Blackman, D. K., Fruh-Green, G. L., Butterfield, D. A., Lilley, M. D., Olson, E. J., SchrenK, M. O., Roe, K. K., Lebon, G. T. et al. (2001) An off-axis hydrothermal vent field near the Mid-Atlantic Ridge at $30^{\circ} \mathrm{N}$. Nature 412(6843), 145-149.

Kelley, D. S., Karson, J. A., FrüH-Green, G. L., Yoerger, D. R., Shank, T. M., Butterfield, D. A., Hayes, J. M., Schrenk, M. O., Olson, E. J., Proskurowski, G. et al. (2005) A serpentinite-hosted ecosystem; the Lost City hydrothermal field. Science 307(5714), 1428-1434.

Klein, F., Bach, W., Jons, N., McCollom, T., Moskowitz, B., and BerquO, T. (2009) Iron partitioning and hydrogen generation during serpentinization of abyssal peridotites from 15 degrees $\mathrm{N}$ on the Mid-Atlantic Ridge. Geochimica et Cosmochimica Acta 73(22), 6868-6893.

Konn, C., Charlou, J. L., Donval, J. P., Holm, N. G., Dehairs, F., and Bouillon, S. (2009) Hydrocarbons and oxidized organic compounds in hydrothermal fluids from Rainbow and Lost City ultramafic-hosted vents. Chemical Geology 258(3-4), 299.

MARTIN, W. and RUSSELL, M. J. (2006) Review: On the origin of biochemistry at an alkaline hydrothermal vent. Philosophical Transactions Of The Royal Society Of London Series B: Biological Sciences, Page FirstCite, DOI 10.1098/rstb.2006.1881, URL: http://dx.doi.org/10.1098/rstb.2006.1881.

MCCollom, T. M. and SEewALD, J. S. (2006) Carbon isotope composition of organic compounds produced by abiotic synthesis under hydrothermal conditions. Earth and Planetary Science Letters 243(1-2), 74-84.

MCCollom, T. M. and SEEWALD, J. S. (2007) Abiotic synthesis of organic compounds in deepsea hydrothermal environments. Chemical Reviews 107, 382-401. 
MCCOLLOM, T. M. and BACH, W. G. (2009) Thermodynamic constraints on hydrogen generation during serpentinization of ultramafic rocks. Geochimica et Cosmochimica Acta 73(3), 856-875.

Proskurowski, G., Lilley, M. D., Seewald, J. S., Fruh-Green, G. L., Olson, E. J., LuPton, J. E., SYlVA, S. P., and Kelley, D. S. (2008) Abiogenic hydrocarbon production at Lost City hydrothermal field. Science 319(5863), 604-607.

Russell, M. J. and Hall, A. J. (2006) The onset and early evolution of life. In: Evolution of Early Earth's Atmosphere, Hydrosphere, and Biosphere - Constraints from Ore Deposits: Geological Society of America Memoir 198, (Ed: S. E. Kesler and H. Ohmoto), Geological Society of America. pp. 1-32.

SEEWALD, J. S. and SEYFRIED, W. E. (1990) The effect of temperature on metal mobility in subseafloor hydrothermal systems: constraints from basalt alteration experiments. Earth and Planetary Science Letters 101(2-4), 388-403.

SEYFRIED, W. E. (1987) Experimental and theoretical constraints on hydrothermal alteration processes at mid-ocean ridges. Annual Review of Earth and Planetary Sciences 15, 317 335.

SEYFRIED, W. E. and DING, K. (1995) Phase equilibria in subseafloor hydrothermal systems: a review of the role of redox, temperature, $\mathrm{pH}$ and dissolved $\mathrm{Cl}$ on the chemistry of hot spring fluids at mid-ocean ridges. In: Seafloor Hydrothermal Systems: Physical, Chemical, Biological, and Geological Interactions, (Ed: S. E. Humphris, R. A. Zierenberg, L. S. Mullineaux, and R. E. Thomson), AGU Monograph, 91, American Geophysical Union. pp. 248-272. 
Sherwood Lollar, B., Westgate, T. D., Ward, J. A., Slater, G. F., and LacrampeCouloume, G. (2002) Abiogenic formation of alkanes in the Earth's crust as a minor source for global hydrocarbon reservoirs. Nature 416(6880), 522-524.

SHOCK, E. L. (1990) Geochemical constraints on the origin of organic compounds in hydrothermal systems. Origins Of Life And Evolution Of The Biosphere 20(3-4), 331-367.

SHOCK, E. L. (1992) Chemical Environments Of Submarine Hydrothermal Systems. Origins Of Life And Evolution Of The Biosphere 22(1-4), 67-107.

SHOCK, E. L. and SchUlTE, M. D. (1998) Organic synthesis during fluid mixing in hydrothermal systems. Journal Of Geophysical Research-Planets 103(E12), 28513-28527.

Tivey, M. K., Humphris, S. E., Thompson, G., Hannington, M. D., and Rona, P. A. (1995) Deducing patterns of fluid flow and mixing within the TAG active hydrothermal mound using mineralogical and geochemical data. Journal Of Geophysical Research-Solid Earth 100(B7), 12527-12555.

YANG, K. and SCOTT, S. D. (2006) Magmatic fluids as a source of metals in seafloor hydrothermal systems. In: Back-Arc Spreading Systems: Geological, Biological, Chemical, and Physical Interactions, (Ed: D. M. Christie, C. R. Fisher, S.-M. Lee, and S. Givens), AGU Monograph, 166, American Geophysical Union. pp. 163-184. 


\title{
CHAPTER 2
}

\section{Experimental investigation of $\mathrm{CO}_{2}$ reduction to $\mathrm{CH}_{4}$ under}

\section{hydrothermal conditions}

\begin{abstract}
Abiotic synthesis of $\mathrm{CH}_{4}$ in ridge-crest hydrothermal fluids is often presumed to occur on the surfaces of catalytically active minerals. However, aqueous reduction of carbon dioxide represents an alternative pathway to form reduced carbon compounds such as $\mathrm{CH}_{4}$, carbon monoxide $(\mathrm{CO})$, methanol $\left(\mathrm{CH}_{3} \mathrm{OH}\right)$ and formic acid $(\mathrm{HCOOH})$. To investigate whether $\mathrm{CH}_{3} \mathrm{OH}$ is a metastable intermediary crucial to hydrothermal $\mathrm{CH}_{4}$ production, aqueous fluids containing $\mathrm{CO}_{2}$ and $\mathrm{H}_{2}$ (added in the form of labeled $\mathrm{H}^{13} \mathrm{COOH}$ ) were heated at 325 and $300^{\circ} \mathrm{C}$ at 350 bar in a flexible-cell gold-Ti hydrothermal apparatus without added mineral catalysts, and the concentrations of $\mathrm{CO}_{2}, \mathrm{H}_{2}, \mathrm{CH}_{4}$ and $\mathrm{CH}_{3} \mathrm{OH}$ were monitored as a function of time over a multiyear period. $\mathrm{CH}_{4}$ production increased with time at $325^{\circ} \mathrm{C}$ before reaching a constant rate. In contrast, the rate of $\mathrm{CH}_{3} \mathrm{OH}$ production decreased with time as a metastable equilibrium with $\mathrm{CO}_{2}$ and $\mathrm{H}_{2}$ was attained relatively quickly at $325^{\circ} \mathrm{C}$. To test the sensitivity of $\mathrm{CH}_{4}$ production to $\mathrm{CH}_{3} \mathrm{OH}$ concentration, the experiment was cooled from 325 to $300^{\circ} \mathrm{C}$. Upon cooling, concentrations of $\mathrm{CH}_{3} \mathrm{OH}$ increased due to the strong temperature dependence of $\mathrm{CO}_{2}-\mathrm{H}_{2}-\mathrm{CH}_{3} \mathrm{OH}$ equilibrium. The rate of $\mathrm{CH}_{4}$ production increased further despite the $25^{\circ} \mathrm{C}$ temperature decrease, strongly suggesting that formation of $\mathrm{CH}_{4}$ from $\mathrm{CO}_{2}$ is controlled by the concentration of the $\mathrm{CH}_{3} \mathrm{OH}$ intermediate. Injection of $\mathrm{H}_{2} \mathrm{~S}$ to the experimental solution did produce ${ }^{13} \mathrm{C}$-labelled
\end{abstract}


$\mathrm{CH}_{3} \mathrm{SH}$ from $\mathrm{H}^{13} \mathrm{COOH}$ but direct reduction of $\mathrm{CO}_{2}$ to $\mathrm{CH}_{3} \mathrm{SH}$ was not observed, suggesting that $\mathrm{CH}_{3} \mathrm{SH}$ does not fulfill the same role as $\mathrm{CH}_{3} \mathrm{OH}$ in regulating the formation rate of $\mathrm{CH}_{4}$. This study indicates that, even in the absence of heterogeneous catalysts, aqueous synthesis of $\mathrm{CH}_{4}$ from $\mathrm{CO}_{2}$ is rapid enough to be observable on a laboratory timescale, and may be a significant source of $\mathrm{CH}_{4}$ to hydrothermal fluids at unsedimented mid-ocean ridge systems such as those hosted in ultramafic rock. 


\section{INTRODUCTION}

Constraining abiogenic (non-biological) sources of methane $\left(\mathrm{CH}_{4}\right)$ is critical to elucidating its production on this planet and on other Solar System bodies such as Mars and Titan (e.g. GLeIN et al., 2008; GLEIN et al., 2009; MUMMA et al., 2009). Methane production has long been associated with serpentinization of ultramafic rock (ABRAJANO et al., 1988; SHERWOOD et al., 1988; ABrajano et al., 1990; ChARlou and Donval, 1993; ChARlou et al., 1998; Kelley et al., 2001; PROSKUROWSKI et al., 2008) and the origin of methane in black smoker fluids has been the subject of considerable discussion ever since seafloor hydrothermal activity was first discovered in 1977 (Welhan, 1988; Kelley and FruH-GreEN, 1999; MCCOLlOM and SEEWALD, 2007). In the absence of a thermogenic (i.e. organic matter pyrolysis), microbial or magmatic origin, non-biological chemical reactions have been invoked as potential mechanisms to generate $\mathrm{CH}_{4}$ in reducing hydrothermal fluids. The term "abiotic synthesis" in hydrothermal fluids refers to the non-biological reduction of oxidized single carbon compounds $\left(\mathrm{CO}_{2}\right.$ or $\left.\mathrm{CO}\right)$ to $\mathrm{CH}_{4}$ and other organic species. Thermodynamic assessments indicate that, at elevated temperatures and pressures, the generation and subsequent cooling of $\mathrm{H}_{2}$-rich aqueous fluids during hydrothermal alteration of basaltic and ultramafic crust strongly favors this process (SHOCK, 1992; SHOCK and SCHULTE, 1998). The possibilities for catalysis by minerals such as magnetite $\left(\mathrm{Fe}_{3} \mathrm{O}_{4}\right.$, FU et al., 2007), Fe-Ni alloy (HORITA and BERNDT, 1999) or chromite $\left(\mathrm{FeCr}_{2} \mathrm{O}_{4}\right.$, FOUSTOUKOS and SEYFRIED, 2004) in oceanic hydrothermal systems enhances the potential for abiotic organic synthesis and these environments have been extensively discussed as a favorable setting from which early life could have emerged (CORLISS et al., 1981; BAROSS and HofFMAN, 1985; SCHUlTE and SHOCK, 1995). The production of methane is also vital to the maintenance of microbial ecosystems in present day hydrothermal vent and plume environments, 
where methanotrophs can represent a large fraction of the microbial population (BAROSS and DEMING, 1995; COWEN et al., 2002; Kelley et al., 2002; Kelley et al., 2004).

A widely cited mechanism responsible for abiotic hydrocarbon synthesis in hydrothermal fluids is the Fischer-Tropsch reaction (CHARLOU et al., 1998; CHARLOU et al., 2002). In its original industrial context, the Fischer-Tropsch reaction refers to the reduction of gas-phase mixtures of $\mathrm{CO}$ and $\mathrm{H}_{2}$ to $\mathrm{CH}_{4}$ and longer chain $n$-alkanes by polymerization on the surface of a transition metal catalyst (ANDERSON, 1984). Whether abiotic $\mathrm{CH}_{4}$ production in hydrothermal systems indeed occurs by the Fischer-Tropsch mechanism is as yet unknown. Formation of $\mathrm{CH}_{4}$ alone may be possible by a Sabatier-type process, with Fe-Ni alloy catalysts (HORITA and BERndT, 1999). For clarity, MCCOLLOM and SEEWALd (2007) recommended the use of the term 'Fischer-Tropsch-type' (FTT) synthesis when referring to purported hydrothermal reduction of $\mathrm{CO}_{2}$ or $\mathrm{CO}$ by heterogeneous (mineral) catalysis, as this does not mistakenly imply any specific reaction mechanism or generation of $\mathrm{C}-\mathrm{C}$ bonds. The potential relevance of mineral-catalyzed synthesis to seafloor hydrothermal systems has lead to numerous experimental studies attempting to simulate the process in the laboratory (BERNDT et al., 1996; MCCOLLOM and SEEWALD, 2001; RUSHDI and SimONEIT, 2001; FOUSTOUKOS and SEYFRIED, 2004; Fu et al., 2007).

Despite the widespread interest in mineral-catalyzed pathways for the production of hydrocarbons, $\mathrm{CH}_{4}$ concentrations in many ultramafic-hosted vent fluids are inconsistent with a single polymerization-type formation mechanism. For example, $\mathrm{CH}_{4}$ concentrations in vent fluids at the Lost City hydrothermal site are elevated relative to the predicted log-linear increase in $n$-alkane abundance with decreasing carbon number for polymerization of hydrocarbons (ANDERSON, 1984; ProskUROWSKI et al., 2008; CHARLOU et al., 2002). In addition to possible biogenic sources (BRADLEY et al., 2009), abiotic mechanisms may be responsible for these elevated abundances. It has largely been assumed that uncatalyzed aqueous reduction of $\mathrm{CO}_{2}$ to 
$\mathrm{CH}_{4}$ by $\mathrm{H}_{2}$ is kinetically prohibited (HORITA and BERNDT, 1999; LUTHER, 2004) and with the exception of recent work by SEEWALD et al. (2006), there have been few studies of hydrothermal $\mathrm{CO}_{2}$ reduction in the absence of heterogeneous catalysts. SEEWALD et al. (2006) observed formation of minor quantities of $\mathrm{CH}_{4}$ and other single carbon compounds from $\mathrm{CO}_{2}$ in the absence of mineral catalysts or gas phase reactants during laboratory experiments and proposed a pathway for sequential reduction of $\mathrm{CO}_{2}$ to $\mathrm{CH}_{4}$ via a series of single carbon intermediates.

Excluding the formation of $\mathrm{C}-\mathrm{C}$ bonds, aqueous reactions among single carbon compounds in the C-H-O system are limited to the carbonate system $\left(\mathrm{CO}_{2}, \mathrm{HCO}_{3}{ }^{-}, \mathrm{CO}_{3}{ }^{2-}\right)$, carbon monoxide $(\mathrm{CO})$, formic acid/formate $\left(\mathrm{HCOOH} / \mathrm{HCOO}^{-}\right)$, formaldehyde $\left(\mathrm{CH}_{2} \mathrm{O}\right)$, methanol $\left(\mathrm{CH}_{3} \mathrm{OH}\right)$ and $\mathrm{CH}_{4}$. The reduction of $\mathrm{CO}_{2}$ to $\mathrm{CO}$ (known as the water-gas shift (WGS) reaction) is relatively rapid (on the order of hours to days) at $150-300^{\circ} \mathrm{C}$ and reversible in the absence of mineral catalysis (SEEWALD et al., 2006). If complete equilibrium between aqueous $\mathrm{CO}_{2}, \mathrm{H}_{2}$ and the single carbon compounds in Figure 2.1 were attained under hydrothermal conditions, $\mathrm{CH}_{4}$ would be the dominant reduced species. The reductive pathway proposed by SEEWALD et al. (2006) does not, however, consider the possible role of reduced sulfur (S) species in carbon dioxide reduction. Reduced $\mathrm{S}$ is ubiquitous in hydrothermal systems (either as dissolved hydrogen sulfide $\left(\mathrm{H}_{2} \mathrm{~S},<1-\right.$ $20 \mathrm{mmol} / \mathrm{kg}$, VON DAMM, 1995) or in the form of sulfide minerals). Given the large number of oxidation states of sulfur and its inherent reactivity in many natural redox reactions, the possibility exists that simple sulfur-bearing compounds may actually be involved in numerous aqueous organic reactions in hydrothermal fluids and play an as yet undetermined role in abiotic synthesis. Aqueous sulfur species have been shown to enhance reaction rates of simple hydrocarbons under hydrothermal conditions (SEEWALD, 2001) and reduced S species are known to act as free radical shuttles (LEIF and SIMONEIT, 2000). The addition of reduced $\mathrm{S}$ to the aqueous C-O-H system allows for several possible S-bearing intermediate oxidation state carbon 
species (Figure 2.1), the stability and behavior of which under hydrothermal conditions is unknown. There have been few studies of organosulfur compounds under hydrothermal conditions (HEINEN and LAUWERS, 1996) but there is extensive interest in the role they may have played in the origin of primitive metabolism (HUBER and WACHTERSHAUSER, 1997; MARTIN and RUSSELL, 2006; MARTIN et al., 2008).

This study builds on the experimental work of SEEWALD et al. (2006), which suggested that the rate of aqueous $\mathrm{CH}_{4}$ production in the absence of mineral catalysis may be governed by redox-dependant metastable equilibrium between $\mathrm{CO}_{2}$ and the intermediates $\mathrm{HCOOH}, \mathrm{CO}, \mathrm{CH}_{2} \mathrm{O}$ and $\mathrm{CH}_{3} \mathrm{OH}$. Metastable equilibrium is defined as any equilibrium energy state of a system other than the lowest energy state (ANDERSON, 2005). If $\mathrm{CH}_{3} \mathrm{OH}$ abundance is governed by metastable equilibrium with $\mathrm{CO}_{2}$ and its subsequent reduction to $\mathrm{CH}_{4}$ is kinetically inhibited, then methanol may represent the overall rate-limiting step in $\mathrm{CO}_{2}$ reduction. Furthermore, the possibility that its S-bearing analog, methanethiol $\left(\mathrm{CH}_{3} \mathrm{SH}\right)$, could be a rate-limiting precursor was not investigated. Thermodynamic data are currently limited to the $n$-alkyl thiols (SCHULTE and ROGERS, 2004), but Figure 2.2 shows that the stability of $\mathrm{CH}_{3} \mathrm{SH}$ with respect to $\mathrm{CO}_{2}$ and $\mathrm{H}_{2}$ is greater than that of $\mathrm{CH}_{3} \mathrm{OH}$. This study therefore attempts to constrain the relative importance of methanol and methanethiol as a potential reaction intermediates in $\mathrm{CO}_{2}$ reduction in the absence of mineral catalysis. The findings of this study have significant implications for the potential of subsurface hydrothermal fluids to generate $\mathrm{CH}_{3} \mathrm{OH}$ and $\mathrm{CH}_{3} \mathrm{SH}$, and to produce $\mathrm{CH}_{4}$ without the involvement of heterogeneous catalysis. 


\section{MethodS}

\subsection{Experimental Apparatus and Design}

The experiment was performed by heating an aqueous solution of formic acid $(\mathrm{HCOOH})$ in a flexible-cell hydrothermal apparatus in the presence and absence of $\mathrm{H}_{2} \mathrm{~S}$. The apparatus used consists of a gold reaction cell (with titanium closure piece, Figure 2.3) contained within a steel pressure vessel which uses $\mathrm{H}_{2} \mathrm{O}$ as a pressurizing fluid (SEYFRIED, 1987). There are several advantages in using this type of reaction cell instead of traditional fixed-volume reactors, and the apparatus has been successfully used to study a variety of aqueous organic reactions under hydrothermal conditions (SEEwald, 2001; MCCollom and SEEwald, 2003a,b; SEEwALd et al., 2006; FU et al., 2007). External control of in situ pressure and temperature conditions in the reaction cell allows the elimination of a vapor phase headspace. This is particularly important in studying aqueous $\mathrm{CH}_{4}$ production rates, as reactants may partition into the headspace and undergo rapid reduction. Fluid samples are removed from the reaction cell by means of a titanium capillary tube and valve leading from the closure piece, without disturbing the pressure and temperature conditions of the cell contents. Rapid cooling of fluid samples upon removal from the reaction cell also minimizes retrograde reactions that can occur during prolonged quenching (SEEWALD, 2001). Prior to the addition of fluid, the gold reaction cell was flame treated in air to several hundred degrees Celsius to anneal the gold and ensure combustion of any potential organic contaminants.

Because the objective of the experiment was to investigate factors controlling the production of $\mathrm{CH}_{4}$ in the absence of heterogeneous catalysts, minerals were not added to the reaction cell. Although the possibility exists that some of the reactions studied may have been catalyzed by the reaction cell materials, previous experiments using the same reaction system suggest that neither gold nor $\mathrm{TiO}_{2}$ are catalytically active with respect to a variety of organic 
reactions at experimental conditions (BELL et al., 1994; MCCOLLOM and SEEWALD, 2003a; SEEWALD et al., 2006). The titanium closure piece/capillary tube was heated overnight at $400^{\circ} \mathrm{C}$ in air to form an inert $\mathrm{TiO}_{2}$ layer on all surfaces in contact with the fluid. Prior to pressurization of the reaction cell, the reaction cell headspace was purged with argon before closure to remove air.

In order to circumvent the technical difficulties of dissolving large quantities of gaseous species into the reaction cell, aqueous formic acid $(\mathrm{HCOOH})$ was used as a source of both $\mathrm{CO}_{2}$ and $\mathrm{H}_{2}$ during the experiment. Previous experiments have shown that $\mathrm{HCOOH}$ undergoes near quantitative decarboxylation to aqueous $\mathrm{CO}_{2}$ and $\mathrm{H}_{2}$ in less than $48 \mathrm{~h}$ under hydrothermal conditions (MCCOLLOM and SEEWALD, 2003a, 2006; SEEWALD et al., 2006). Isotopicallylabeled formic acid $\left(99 \% \mathrm{H}^{13} \mathrm{COOH}\right.$, Cambridge Isotopes Labs) was used to allow differentiation between bona fide reaction products (i.e. formed from $\mathrm{HCOOH}$ or $\mathrm{CO}_{2}$ ) and compounds derived from background sources such as thermal decomposition of background dissolved organic carbon (DOC).

Stage (1) of the experiment consisted of heating $39.4 \mathrm{~g}$ of a solution containing $123 \mathrm{mmol} / \mathrm{kg} \mathrm{H}^{13} \mathrm{COOH}$ and $9.83 \mathrm{mmol} / \mathrm{kg} \mathrm{NaCl}$ at $325^{\circ} \mathrm{C}$ and $35 \mathrm{MPa}$ for 956 days. The $\mathrm{NaCl}$ was added as a conservative tracer to monitor potential leakage of the reaction cell contents into the surrounding $\mathrm{NaCl}$-free pressurizing fluid. Chemical disequilibrium was induced after 956 days by reducing the temperature (at $35 \mathrm{MPa}$ ) to $300^{\circ} \mathrm{C}$ and the subsequent evolution of dissolved species concentrations was monitored as a function of time (Stage (2)). The purpose of cooling the reaction cell was to investigate the effects of temperature and carbon speciation on the rate of $\mathrm{CH}_{4}$ formation from $\mathrm{CO}_{2}$. As can be seen from Figure 2.2, the overall reactions for $\mathrm{CH}_{3} \mathrm{OH}$ and $\mathrm{CH}_{4}$ formation from $\mathrm{CO}_{2}$ and $\mathrm{H}_{2}$ are thermodynamically favored at lower temperatures. The pressure vessel temperature was stable at $300^{\circ} \mathrm{C}$ within 6 hours of cooling the furnace, thereby 
ensuring near-instantaneous disequilibrium on the timescale of these reactions. After 1575 days, the effect of sulfur addition to the aqueous C-O-H system was examined by injection () of $20.5 \mathrm{~g}$ of a solution containing $40 \mathrm{mmol} / \mathrm{kg}$ sodium sulfide $\left(\mathrm{Na}_{2} \mathrm{~S}\right)$ adjusted to $\mathrm{pH} 4$ to 5 with hydrochloric acid, thereby yielding a solution of $\mathrm{NaCl}$ and $\mathrm{H}_{2} \mathrm{~S}$ (Stage (3)). The injected solution also contained $132 \mathrm{mmol} / \mathrm{kg} \mathrm{H}{ }^{13} \mathrm{COOH}$ to replenish the $\mathrm{CO}_{2}$ and $\mathrm{H}_{2}$ inventory of the reaction cell solution.

\subsection{Analysis of Dissolved Species}

Throughout the course of the experiment, separate $\sim 0.5-1 \mathrm{~g}$ fluid samples were taken in duplicate on a given sampling event with glass/Teflon gas-tight syringes for analysis of dissolved species. Total dissolved $\mathrm{CO}_{2}\left(\Sigma \mathrm{CO}_{2}=\left[\mathrm{CO}_{2(\mathrm{aq})}\right]+\left[\mathrm{HCO}_{3}^{-}\right]+\left[\mathrm{CO}_{3}{ }^{2-}\right]\right), \mathrm{CH}_{4}$ and $\mathrm{C}_{1}-\mathrm{C}_{5}$ hydrocarbons were analyzed using a purge and trap system interfaced directly to a gas chromatograph (GC) with a Porapak Q packed column and serially connected thermal conductivity (TCD) and flame ionization detectors (FID). Quantitative extraction of all carbonate species as $\mathrm{CO}_{2(\mathrm{~g})}$ was accomplished by injection of fluid samples into a He purge cell containing a $25 \mathrm{wt} \%$ phosphoric acid solution. During Stage (3) of the experiment, methanethiol concentrations were also determined by purge-and-trap GC-FID and total dissolved sulfide $\left(\mathrm{\Sigma H}_{2} \mathrm{~S}\right.$

$=\mathrm{H}_{2} \mathrm{~S}+\mathrm{HS}^{-}+\mathrm{S}^{2-}$ ) was determined gravimetrically following precipitation as $\mathrm{Ag}_{2} \mathrm{~S}$. Dissolved $\mathrm{H}_{2}$ was analyzed on a GC using a $5 \AA$ molecular sieve packed column with TCD, following headspace extraction with $\mathrm{N}_{2}$ gas. $\mathrm{Cl}$ was analyzed by ion exchange chromatography on a Dionex DX500 system with conductivity detection. Concentrations of total formic acid $\left(\Sigma \mathrm{HCOOH}=\mathrm{HCOOH}+\mathrm{HCOO}^{-}\right)$were also determined by ion chromatography using an IonPac ${ }^{\circledR}$ ICE-AS1 ion exclusion column. Methanol concentrations were determined by split injection of aqueous samples onto a HP $6890 \mathrm{GC}$ with an EC-WAX column and flame ionization detector. 
To monitor incorporation of the ${ }^{13} \mathrm{C}$ label into $\mathrm{CH}_{3} \mathrm{OH}, \mathrm{CH}_{3} \mathrm{SH}$ and $\mathrm{CH}_{4}$, selected fluid samples were analyzed by gas chromatography-mass spectrometer (Hewlett-Packard 5973 mass selective detector). The analytical uncertainty of all dissolved species measurements is estimated at $\pm 5 \%$ (2s). 


\section{RESULTS}

\section{1. $\mathrm{CO}_{2}$ and $\mathrm{H}_{2}$}

Rapid production of $\mathrm{CO}_{2}$ and $\mathrm{H}_{2}$ in equimolar concentrations $(\sim 120 \mathrm{mmol} / \mathrm{kg})$ was observed within 78 days of initial heating (Table 2.1), consistent with decomposition of $\mathrm{HCOOH}$ which decreased to $<0.3 \mathrm{mmol} / \mathrm{kg}$. This is consistent with previous use of $\mathrm{HCOOH}$ which revealed that $\mathrm{CO}_{2}-\mathrm{H}_{2}-\mathrm{HCOOH}$ equilibration is rapid and occurs in less than 48 hours at temperatures of $\geq 300^{\circ} \mathrm{C}$ (SEEWALD et al., 2006). $\mathrm{CO}_{2}$ concentrations, initially $120 \mathrm{mmol} / \mathrm{kg}$, remained relatively constant throughout the experiment but decreased slightly at the end of the $325^{\circ} \mathrm{C}$ phase (Figure 2.4). $\mathrm{H}_{2}$ concentrations appeared to decrease monotonically from the initial value of $118 \mathrm{mmol} / \mathrm{kg}$ to $61 \mathrm{mmol} / \mathrm{kg}$ by the end of the $300^{\circ} \mathrm{C}$ phase of the experiment (Figure 2.4). Based on the concentrations of $\mathrm{CH}_{4}$ and $\mathrm{CH}_{3} \mathrm{OH}$ after 1560 days (Table 2.1) and the stoichiometry of the overall reduction reactions (Figure 2.2), production of these species can only account for the consumption of $\sim 17 \mathrm{mmol} / \mathrm{kg}$ of the initial $\mathrm{H}_{2}$ concentration. Constant $\mathrm{Cl}^{-}$ concentrations (Table 2.1) indicate that the reaction cell maintained integrity during the experiment, precluding leakage as the cause for the observed decrease. It may be possible that the long duration of this experiment facilitated slow diffusion of $\mathrm{H}_{2}$ through the reaction cell materials. Alternatively, reduction of the $\mathrm{TiO}_{2}$ surface of the closure piece to Ti or formation of a titanium (II) carbonate phase may have occurred. Though there are no thermodynamic data for the latter, it may explain the loss of both $\mathrm{H}_{2}$ and $\mathrm{CO}_{2}$ towards the end of the $325^{\circ} \mathrm{C}$ phase. The subsequent increase in $\mathrm{CO}_{2}$ upon cooling might therefore reflect the effect of temperature on the solubility of such phases. 


\section{2. $\mathrm{CH}_{4}$ and $\mathrm{CH}_{3} \mathrm{OH}$ formation}

The long time scale of this experiment allowed substantial quantities of aqueous $\mathrm{CH}_{4}$ and $\mathrm{CH}_{3} \mathrm{OH}$ to be generated (Table 2.1). The average rate of $\mathrm{CH}_{4}$ production increased with time during the $325^{\circ} \mathrm{C}$ phase from $0.5 \mu \mathrm{mol} \mathrm{kg} \mathrm{day}^{-1}$ (prior to 78 days) to $1.0 \mu \mathrm{mol} \mathrm{kg}^{-1}$ day $^{-1}$ at 851 days, though $\mathrm{CH}_{4}$ concentrations increased much more slowly than $\mathrm{CH}_{3} \mathrm{OH}$ (Figure 2.4). Following the temperature reduction to $300^{\circ} \mathrm{C}, \mathrm{CH}_{4}$ concentrations in Stage (2) steadily increased at a similar average rate to the latter portion of Stage (1) but then increased to $1.6 \mu \mathrm{mol} \mathrm{kg} \mathrm{day}^{-1}$ in the final stages of the $300^{\circ} \mathrm{C}$ phase. By the end of the experiment, $\sim 1 \%$ of the total carbon in the fluid had been converted to $\mathrm{CH}_{4}$.

In contrast to $\mathrm{CH}_{4}$, production of $\mathrm{CH}_{3} \mathrm{OH}$ was initially rapid at both 325 and $300^{\circ} \mathrm{C}$ and slowed with time. Concentrations of $\mathrm{CH}_{3} \mathrm{OH}$ increased during the early stages of the experiment before reaching a constant value $(\sim 1.2 \mathrm{mmol} / \mathrm{kg})$ by the end of Stage (1), (Figure 2.4$)$. After the temperature was reduced to $300^{\circ} \mathrm{C}$ at 956 days, production of $\mathrm{CH}_{3} \mathrm{OH}$ increased, with concentrations rapidly rising to $3.5 \mathrm{mmol} / \mathrm{kg}$ by the end of Stage (2). Though less pronounced than Stage (1), the rate of $\mathrm{CH}_{3} \mathrm{OH}$ formation gradually decreased with time in Stage (2) also (Figure 2.4).

Extensive incorporation of the ${ }^{13} \mathrm{C}$ label into both $\mathrm{CH}_{3} \mathrm{OH}$ and $\mathrm{CH}_{4}$ was evident, based on GC-MS analysis of samples taken at 1560 and 78 days, respectively (Figure 2.5). Incorporation of the ${ }^{13} \mathrm{C}$ label was not detected in any of the $\mathrm{C}_{2+}$ hydrocarbons analyzed. This confirms that $\mathrm{CH}_{3} \mathrm{OH}$ and $\mathrm{CH}_{4}$ are predominantly bona fide reaction products of $\mathrm{CO}_{2}$ or $\mathrm{HCOOH}$ reduction, and not derived from thermal decomposition of the background DOC of the solution. The dissolved organic carbon content of the Milli-Q water used to make the initial solution is estimated to be $\sim 40 \mu \mathrm{mol} / \mathrm{kg}$ (B. Van Mooy, pers. comm.). Hence, it is likely that the observed 
$\mathrm{C}_{2+}$ compounds were merely derived from thermal decomposition of the background DOC in the solution.

\subsection{Other $\mathrm{C}$ species}

Concentrations of $\mathrm{C}_{2}-\mathrm{C}_{5}$ hydrocarbons appeared to increase during the $325^{\circ} \mathrm{C}$ phase but subsequently remained constant throughout the remainder of the experiment and were low overall $\left(<30 \mu \mathrm{mol} / \mathrm{kg}\right.$ ) relative to $\mathrm{CH}_{4}$ (Table 1). The postulated intermediate formaldehyde (Figure 2.1) was not observed during the course of the experiment, though it would not have been detected at levels below $\sim 10^{-7} \mathrm{~mol} / \mathrm{kg}$. It is also possible that formaldehyde-methanediol equilibrium could be occurring, which could explain the observed lack of formaldehyde. At room temperatures, formaldehyde in solution predominantly exists as methanediol (ANSLYN and DOUGHERTY, 2005), a species which could not be analyzed. There are no thermodynamic data for diols under hydrothermal conditions to evaluate this possibility, however. Furthermore, given the large concentrations of $\mathrm{CO}_{2}$ used in this experiment, accurate mass balance on the abundance of reduced species present at much lower abundances is not possible.

\subsection{Sulfur-bearing species}

The injection of the $\mathrm{Na}_{2} \mathrm{~S}$ and $\mathrm{HCOOH}$ solution produced a solution composition similar to Stages (1) and (2) with $\mathrm{CO}_{2}$ concentrations of $108 \mathrm{mmol} / \mathrm{kg}, \mathrm{H}_{2}$ concentrations of $85 \mathrm{mmol} / \mathrm{kg}$ except with the addition of $\mathrm{H}_{2} \mathrm{~S}$ at concentrations at 20-24mmol/kg (Figure 2.4). $\mathrm{CO}_{2}$ concentrations remained relatively constant while $\mathrm{H}_{2}$ concentrations decreased steadily in a similar manner to the previous stages. Rapid production of $\mathrm{CH}_{3} \mathrm{SH}$ occurred immediately after injection at the start of Stage (3), with a maximum concentration of $1.1 \mathrm{mmol} / \mathrm{kg}$. However, production abruptly ceased when $\mathrm{HCOOH}$ decomposition to $\mathrm{CO}_{2}$ and $\mathrm{H}_{2}$ was complete and 
$\mathrm{CH}_{3} \mathrm{SH}$ concentrations subsequently decreased with time to low values $(<0.2 \mathrm{mmol} / \mathrm{kg})$ by the end of Stage (3). Incorporation of the ${ }^{13} \mathrm{C}$ label into $\mathrm{CH}_{3} \mathrm{SH}$ was evident (Figure 2.5) indicating that it was not derived from background contamination. In contrast to the previous stages, $\mathrm{CH}_{4}$ production was initially rapid but slowed with time (Figure 2.5) and although dilution occurred due to injection, $\mathrm{CH}_{3} \mathrm{OH}$ concentrations did not subsequently vary outside of analytical error. The average rate of $\mathrm{CH}_{4}$ production during Stage (3) was $1.9 \mu \mathrm{mol} / \mathrm{d}$. 


\section{DISCUSSION}

\subsection{Thermodynamic constraints on metastable equilibrium}

Interpretation of the analytical results of this experiment in a thermodynamic context indicates that equilibrium between $\mathrm{CO}_{2}, \mathrm{H}_{2}$ and $\mathrm{CH}_{3} \mathrm{OH}$ is rapid enough to be observable on laboratory timescales. The extent to which aqueous species may have attained a state of thermodynamic equilibrium (metastable or stable) during the experiment can be evaluated by calculating the chemical affinity $(A)$ for a given reaction according to the following relationship:

$$
A=-\Delta_{\mathrm{r}} G=-R T \ln \left(Q_{r} / K_{e q}\right)
$$

Where $R$ is the universal gas constant, $T$ is temperature in Kelvin, $Q_{r}$ is the reaction quotient and $K_{e q}$ is the equilibrium constant for the reaction in question. Positive values of $A$ indicate a thermodynamic drive for the reaction to proceed from left to right as written (i.e. $A=-\Delta_{r} G$ for a given reaction). At thermodynamic equilibrium, values of $Q$ and $K_{e q}$ are equal and $A$ equals zero. Requisite thermodynamic data for these calculations were generated from the SUPCRT92 thermodynamic database JOHNSON et al. (1992), with additional data from SHOCK (1995). Given the presence of solely non-ionic or univalent species and the low solution ionic strength (of order $\sim 10^{-2}$, activity coefficients of unity were assumed for all aqueous species due to the low concentration of dissolved ions in solution and the concomitant lack of significant 'salting out' effects (GARRELS and CHRIST, 1965; ANDERSON, 2005). Due to uncertainties in the thermodynamic data used to perform these calculations, an affinity of exactly zero at equilibrium should not be expected. Calculated affinities of $0 \pm 4 \mathrm{~kJ} / \mathrm{mol}$ are typically assumed to represent equilibrium (SEEWALD, 2001), consistent with the errors estimated by SHOCK and HELGESON (1990) in derivation of $\Delta_{r} G^{o}$ values. Evaluation of chemical affinities for both $\mathrm{CH}_{3} \mathrm{OH}\left(A_{\text {Methanol }}\right)$ and $\mathrm{CH}_{4}\left(A_{\text {Methane }}\right)$ formation reactions shown in Figure 2.2 reveals that $\mathrm{CO}_{2}-\mathrm{H}_{2}-\mathrm{CH}_{3} \mathrm{OH}$ equilibration was essentially complete by the end of each of the three stages as values approach 
within $4 \mathrm{~kJ} / \mathrm{mol}$ of zero (Figure 2.6). Following the temperature reduction to $300^{\circ} \mathrm{C}(956$ days), $A_{\text {Methanol }}$ increased markedly, consistent with the strong temperature dependence of the $K_{e q}$ for $\mathrm{CH}_{3} \mathrm{OH}$ production (Figure 2.2), but rapidly returned to equilibrium towards the end of the experiment as $\mathrm{CH}_{3} \mathrm{OH}$ concentrations increased. The lack of variation in $\mathrm{CH}_{3} \mathrm{OH}$ concentrations in Stage (3) reflects a decreased drive for $\mathrm{CH}_{3} \mathrm{OH}$ production due to decreased $\mathrm{H}_{2}$ activity. In contrast to $A_{\text {Methanol }}$, affinities for the formation of $\mathrm{CH}_{3} \mathrm{SH}$ by the reduction of $\mathrm{CO}_{2}$ (reaction shown in Figure 2.2) were high $(27.0-34.3 \mathrm{~kJ} / \mathrm{mol})$ throughout Stage (3) and, rather than approach equilibrium values, actually increased with time (Figure 2.6). $A_{\text {Methane }}$ also remained 1 to 2 orders of magnitude higher than $A_{\text {Methanol }}$ for all of the experiment (Figure 2.6), indicating a consistent strong thermodynamic drive for $\mathrm{CH}_{4}$ production to proceed.

In the absence of analytical constraints on all species involved in the reductive pathway of SEEWALD et al. (2006), (Figure 2.1), speciation calculations may be used to further constrain the composition of the experimental solutions expected for equilibrium. By allowing an idealized initial fluid composition ( $120 \mathrm{mmol} / \mathrm{kg} \mathrm{CO}_{2}$ and $\mathrm{H}_{2}$ ) to reach equilibrium according to the reactions shown in black in Figure 2.1, in addition to the reactions of the carbonate system, a theoretical equilibrium fluid composition may be calculated for each phase of the experiment by simultaneous solving the respective mass balance and mass action expressions. Two models of the experimental solution composition were tested using this approach and predicted concentrations compared to measurements. The first scenario assumed that $\mathrm{CH}_{4}$ formation does not occur due to kinetic inhibition, thereby allowing the calculation of a theoretical metastable equilibrium composition in which $\mathrm{CO}_{2}$ is allowed to reach equilibrium with the aqueous species $\mathrm{HCO}_{3}^{-}, \mathrm{CO}_{3}{ }^{2-}, \mathrm{HCOOH}, \mathrm{HCOO}^{-}, \mathrm{CO}, \mathrm{CH}_{2} \mathrm{O}$ and $\mathrm{CH}_{3} \mathrm{OH}$ only. In the second scenario, the kinetic inhibition was removed and $\mathrm{CO}_{2}$ was allowed to equilibrate with $\mathrm{CH}_{4}$ in addition to the above 
species. This latter case differs from the former in that it represents the total equilibrium state of the fluid.

Examination of Figures 2.7 (A) and (D) reveals that the assumption of kinetic inhibition of methane is a more realistic approximation of the real system composition, which closely matches this model. The measured abundances of $\mathrm{CH}_{3} \mathrm{OH}$ are greatly in excess of what total equilibrium would predict (Figures 2.7 (C) and (D)). Thus, metastable equilibrium between $\mathrm{CO}_{2}$ and $\mathrm{CH}_{3} \mathrm{OH}$ represents the best explanation for the observed variations in fluid chemistry. Although measured $\mathrm{CH}_{3} \mathrm{OH}$ concentrations did not quite reach the value predicted for metastable equilibrium by the end of the $300^{\circ} \mathrm{C}$ phase, the values agree to within a factor of 3 . Losses of $\mathrm{H}_{2}$ (to which equilibrium $\mathrm{CH}_{3} \mathrm{OH}$ abundance is highly sensitive) in the experiment relative to the speciation model conditions are likely to be responsible for this offset.

Measured concentrations of $\mathrm{CH}_{3} \mathrm{SH}$ during Stage (3) did not approach values predicted for equilibrium with $\mathrm{CO}_{2}, \mathrm{H}_{2}$ and $\mathrm{H}_{2} \mathrm{~S}$ (Figure 2.7(E)) and were almost 2 orders of magnitude too low by the end of Stage (3). Figure 2.7 (E) shows that $\mathrm{CH}_{3} \mathrm{SH}$ would be far more abundant than $\mathrm{CH}_{3} \mathrm{OH}$ if it reached metastable equilibrium with $\mathrm{CO}_{2}, \mathrm{H}_{2}$ and $\mathrm{H}_{2} \mathrm{~S}$, a situation that was never realized during the experiment. Combined with the affinity considerations above, this provides compelling evidence for kinetic inhibition of $\mathrm{CH}_{3} \mathrm{SH}$ formation from $\mathrm{CO}_{2}, \mathrm{H}_{2}$ and $\mathrm{H}_{2} \mathrm{~S}$. In contrast, $\mathrm{CH}_{3} \mathrm{OH}$ remained in equilibrium with $\mathrm{CO}_{2}$ and $\mathrm{H}_{2}$ in the presence of $\mathrm{H}_{2} \mathrm{~S}$ (Figure 2.7(E)).

\subsection{The relative roles of $\mathrm{CH}_{3} \mathrm{OH}$ and $\mathrm{CH}_{3} \mathrm{SH}$ in abiotic synthesis of $\mathrm{CH}_{4}$}

Significant quantities of $\mathrm{CH}_{4}$ and $\mathrm{CH}_{3} \mathrm{OH}$ were formed by reduction of $\mathrm{CO}_{2}$ during the course of this experiment and rates of $\mathrm{CH}_{4}$ production appear to have been regulated by $\mathrm{CO}_{2}-\mathrm{H}_{2}-$ $\mathrm{CH}_{3} \mathrm{OH}$ metastable equilibrium. By reducing the temperature of the system, the effect of temperature on $\mathrm{CH}_{3} \mathrm{OH}$ stability was evident. According to Figure 2.2, the drop in temperature of 
$25^{\circ} \mathrm{C}$ corresponded to an almost ten-fold increase in $\mathrm{CH}_{3} \mathrm{OH}$ abundance (cf. Figures 2.7(A) and (B)). Despite the enhanced thermodynamic drive, lower $\mathrm{CH}_{4}$ production rates might have been expected at $300^{\circ} \mathrm{C}$ due to a strong positive correlation of reaction kinetics with temperature. However, if $\mathrm{CH}_{3} \mathrm{OH}$ reduction is the rate-limiting step and its equilibrium abundance influences $\mathrm{CH}_{4}$ production rates, then the loss of any kinetic advantages available to the reaction of $\mathrm{CH}_{3} \mathrm{OH}$ to form $\mathrm{CH}_{4}$ at $325^{\circ} \mathrm{C}$ could potentially be offset by increased $\mathrm{CH}_{3} \mathrm{OH}$ concentrations at $300^{\circ} \mathrm{C}$. Increased $\mathrm{CH}_{3} \mathrm{OH}$ concentrations after cooling were accompanied by increases in $\mathrm{CH}_{4}$, and the average $\mathrm{CH}_{4}$ production rate during Stage (2) exceeded that of Stage (1), despite the lower temperature of the former. The increase in $\mathrm{CH}_{4}$ production rates with time during both stages noted above strongly suggests a dependency on $\mathrm{CH}_{3} \mathrm{OH}$ concentrations, which were initially low but increased until metastable equilibrium with $\mathrm{CO}_{2}$ was obtained. By limiting the abundance of $\mathrm{CH}_{3} \mathrm{OH}$, metastable $\mathrm{CO}_{2}-\mathrm{H}_{2}-\mathrm{CH}_{3} \mathrm{OH}$ equilibrium may therefore influence the production rate of $\mathrm{CH}_{4}$.

The data from the $\mathrm{H}_{2} \mathrm{~S}$ free stage of the experiment may be used to derive estimates of the rate constant, $k$, for $\mathrm{CH}_{4}$ formation from $\mathrm{CH}_{3} \mathrm{OH}$ at both $325^{\circ} \mathrm{C}$ and $300^{\circ} \mathrm{C}$. Assuming the rate of reaction is first order with respect to both the concentration of $\mathrm{H}_{2}$ and $\mathrm{CH}_{3} \mathrm{OH}$, an equation of the following form can be used to estimate $k$ :

$$
\mathrm{d}\left[\mathrm{CH}_{4}\right] / \mathrm{d} t=k\left[\mathrm{CH}_{3} \mathrm{OH}\right]\left[\mathrm{H}_{2}\right]
$$

where $t$ is time in days and [i] is the measured concentration of species ' $i$ '. Using average rates of $\mathrm{CH}_{4}$ formation and concentration data from 851 days and 1560 days, estimated values of $k$ at $325^{\circ} \mathrm{C}$ and $300^{\circ} \mathrm{C}$ are calculated to be $0.9 \times 10^{-8}$ and $1.2 \times 10^{-8} \mu \mathrm{mol} \mathrm{kg}^{-1}$ day $^{-1}$, respectively. In contrast to $\mathrm{CH}_{3} \mathrm{OH}, \mathrm{CH}_{3} \mathrm{SH}$ does not appear to exert the same influence on $\mathrm{CH}_{4}$ production rates as metastable $\mathrm{CO}_{2}-\mathrm{H}_{2}-\mathrm{H}_{2} \mathrm{~S}-\mathrm{CH}_{3} \mathrm{SH}$ equilibrium was never attained. It is likely that, rather than being a product of direct $\mathrm{CO}_{2}$ reduction, $\mathrm{CH}_{3} \mathrm{SH}$ formed during the earliest 
portion of Stage (3) as a result of $\mathrm{HCOOH}$ decomposition in the presence of $\mathrm{H}_{2} \mathrm{~S}$. This may have been facilitated by intermediates such as $\mathrm{CO}$ or other species which could have been present in large quantities before $\mathrm{HCOOH}$ decomposition was complete. This is consistent with the lack of $\mathrm{CH}_{3} \mathrm{SH}$ production subsequent to the transformation of $\mathrm{HCOOH}$ to $\mathrm{CO}_{2}$ and $\mathrm{H}_{2}$. A possible explanation for kinetic inhibition is that direct reduction of $\mathrm{CO}_{2}$ to $\mathrm{S}$-bearing intermediates inherently requires reaction of both $\mathrm{H}_{2} \mathrm{~S}$ and $\mathrm{H}_{2}$ with $\mathrm{CO}_{2}$ (Figure 2.1), which due to molecular collision considerations, may be kinetically inhibited. The decrease in $\mathrm{CH}_{4}$ production rate with time in Stage (3) suggests that formed $\mathrm{CH}_{3} \mathrm{SH}$ subsequently reacted to produce $\mathrm{CH}_{4}$, producing lesser amounts with time as the supply of $\mathrm{CH}_{3} \mathrm{SH}$ was exhausted. However, given that concentrations of $\mathrm{CH}_{3} \mathrm{SH}$ did not achieve metastable equilibrium with $\mathrm{CO}_{2}$, the presence of $\mathrm{H}_{2} \mathrm{~S}$ does not appear to substantially affect the rate of formation of $\mathrm{CH}_{4}$ in the absence of high concentrations of $\mathrm{HCOOH}$.

\subsection{Implications for hydrothermal systems}

\subsection{1 $\mathrm{CH}_{3} \mathrm{OH}$ and $\mathrm{CH}_{4}$ formation}

In ultramafic-hosted hydrothermal systems, aqueous $\mathrm{CO}_{2}$ and $\mathrm{H}_{2}$ concentrations are typically an order of magnitude lower than those used in this study (see MCCOLLOM and SEEWALD, 2007 for review). The abundance of $\mathrm{CH}_{3} \mathrm{OH}$ and other intermediates in seafloor hydrothermal systems will be regulated by the residence time of fluids in high-temperature reaction zones, as well as the physical and chemical characteristics of the subsurface environment. $\mathrm{CH}_{3} \mathrm{OH}$ abundances will be a strong function of the temperature structure of the subseafloor environment and will be more abundant at lower temperatures. Measured vent temperatures in ultramafic hydrothermal systems investigated to date span a wide range $\left(28-365^{\circ} \mathrm{C}\right.$, CHARLOU et al., 2002; PROSKUROWSKI et al., 2008), but theoretical considerations estimate subsurface 
temperatures in the range of $200-400^{\circ} \mathrm{C}$ (ALLEN and SEYFRIED, 2004; FOUSTOUKOS et al., 2008). Recent thermodynamic modeling of serpentinization processes indicates that associated $\mathrm{H}_{2}$ production is likely to be maximal in the temperature range of $200-315^{\circ} \mathrm{C}$ (KLEIN et al., 2009; MCCOLLOM and BACH, 2009). Thus, the increased stability of $\mathrm{CH}_{3} \mathrm{OH}$ within this lower temperature range in conjunction with elevated $\mathrm{H}_{2}$ activities could result in substantial $\mathrm{CH}_{4}$ production without mineral catalysis in systems where serpentinization is occurring at these conditions. The findings of this experiment therefore have significant implications for $\mathrm{CH}_{4}$ production in such systems.

In contrast to temperature, subsurface residence times of hydrothermal fluids are much less constrained, but estimates from studies of short-lived radionuclides in vent fluids from various sites along the Juan de Fuca Ridge indicate that the residence times for fluids in the high temperature $\left(>200^{\circ} \mathrm{C}\right)$ regions of the hydrothermal reservoir are on the order of years (KADKO and MOORE, 1988; KADKO and BUTTERFIELD, 1998), consistent with estimates based on geophysical constraints (FISHER, 2003). Thus, there is likely to be sufficient time for $\mathrm{CO}_{2}-\mathrm{H}_{2}-\mathrm{CH}_{3} \mathrm{OH}$ equilibrium to be achieved in subseafloor hydrothermal fluids and if fluids within the lower temperature range have longer subsurface residence times than hotter $\left(\sim 400^{\circ} \mathrm{C}\right)$ fluids, increased $\mathrm{CH}_{4}$ production might be possible despite slower kinetics.

An important implication of this study is the possibility that aqueous $\mathrm{CH}_{4}$ production could proceed at reasonable rates in natural systems without the need to invoke heterogeneous catalysis. The general view that mineral-catalyzed mechanisms are the only plausible pathway for abiotic $\mathrm{CH}_{4}$ synthesis has lead to many experimental studies using catalysts such as ironnickel alloy and chromium (HORITA and BERNDT, 1999; FOUSTOUKOS and SEYFRIED, 2004). Although transition metals are present in basaltic and ultramafic crust, it has been largely ignored that catalytic surfaces may be effectively 'poisoned' by the abundant reduced sulfur species in 
hydrothermal systems (HAYATSU and ANDERS, 1981; MILLER and BADA, 1988) and such experiments typically have not included any $\mathrm{S}$ forms. It is widely known that $\mathrm{S}$ is detrimental to the Fischer-Tropsch reaction in particular (LIU et al., 1994; RHODES et al., 2000). Thus, the applicability of this type of synthesis to S-rich natural hydrothermal systems is still a matter of debate. The possibility of homogeneous reduction also offers an explanation for the excess $\mathrm{CH}_{4}$ relative to the Anderson-Schulz-Flory distribution of $n$-alkanes at the Lost City hydrothermal site (PROSKUROWSKI et al., 2008). Reaction zone conditions in this system are estimated to be in the vicinity of $250^{\circ} \mathrm{C}$ (ALLEN and SEYFRIED, 2004; FoustoukOs et al., 2008), which would be favorable for the production of $\mathrm{H}_{2}$ and $\mathrm{CH}_{3} \mathrm{OH}$. While it is possible that $\mathrm{CH}_{4}$ synthesis from $\mathrm{CH}_{3} \mathrm{OH}$ could also occur in basalt-hosted systems, there may be kinetic issues associated with the drastically lower $\mathrm{H}_{2}$ concentrations typical of these systems.

This study also has significant implications for methanol synthesis in hydrothermal systems. Previous experimental studies of magnetite-catalyzed gas phase reactions indicate that abiotic synthesis of large quantities of $\mathrm{CH}_{3} \mathrm{OH}$ could be achieved in seafloor hydrothermal systems during short-lived diking-eruptive events, which are known to release large quantities of $\mathrm{CO}_{2}$ and $\mathrm{H}_{2}$ (HollowAY and O'DAY, 2000; VogLeSONGER et al., 2001). Such events are also typically associated with intense 'megaplumes', and large increases in observed $\mathrm{CH}_{4}$ concentrations (see KELLEY et al., 2004 for review). The data presented here show that methanol formation occurs readily in an aqueous phase and the $\mathrm{CO}_{2}-\mathrm{H}_{2}-\mathrm{CH}_{3} \mathrm{OH}$ equilibration timescale is comparable to estimates of residence times for fluids in ridge-crest hydrothermal systems. Hence, unless significant catalysis is occurring, it is unlikely that the short (weeks to months) timescales of diking-eruptive events could lead to significant $\mathrm{CH}_{3} \mathrm{OH}$ production in the aqueous phase. However, as yet, there have been no reported measurements of $\mathrm{CH}_{3} \mathrm{OH}$ concentrations in vent fluids to test hypotheses for the importance of methanol in hydrothermal systems. Table 2.2 
shows predicted $\mathrm{CH}_{3} \mathrm{OH}$ abundances for two highly reducing vent fluids from the Mid-Atlantic Ridge sites 'Rainbow' and 'Logatchev', and these concentrations may be measurable if analytical methods are developed.

\subsection{2 $\mathrm{CH}_{3} \mathrm{SH}$ formation}

The results presented here provide compelling evidence for kinetic inhibition of aqueous $\mathrm{CH}_{3} \mathrm{SH}$ formation from $\mathrm{CO}_{2}, \mathrm{H}_{2}$ and $\mathrm{H}_{2} \mathrm{~S}$. There is extensive interest in the formation of $\mathrm{CH}_{3} \mathrm{SH}$ by $\mathrm{CO}_{2}$ reduction in ultramafic-hosted hydrothermal fluids as it is considered a possible precursor in the synthesis of thioester (HUBER and WACHTERSHAUSER, 1997; MARTIN and RUSSELL, 2006; RUSSELL and HALL, 2006; MARTIN et al., 2008). The latter is the key functional group of the Acetyl-CoA enzyme, and prebiotic thioester formation is a crucial component of theories which postulate that primitive metabolism preceded the emergence of RNA-like material on the early Earth (DE DUVE, 1991; HUBER and WACHTERSHAUSER, 1997; RUSSELL and HALl, 2006). In CHAPTER 2, the distribution of $\mathrm{CH}_{3} \mathrm{SH}$ in hydrothermal fluids from a variety of geologic settings of varying redox states is shown to be inconsistent with $\mathrm{CO}_{2}$ reduction as a formation mechanism and likely reflects other, possibly non-abiotic, sources. Combined, these observations suggest the potential for $\mathrm{CH}_{3} \mathrm{SH}$ synthesis in seafloor hydrothermal fluids by this mechanism is much more limited than previously thought. 


\section{CONCLUSIONS}

A long term hydrothermal experiment has demonstrated significant aqueous $\mathrm{CO}_{2}$ reduction to $\mathrm{CH}_{4}$ in the absence of mineral catalysts on timescale analogous to fluid residence times in hydrothermal systems. Long term production rates of $\mathrm{CH}_{4}$ are influenced by the equilibrium abundance of its metastable precursor, $\mathrm{CH}_{3} \mathrm{OH}$, the stability of which is highly dependant on temperature and redox. The experimental data indicate that reduction of $\mathrm{CO}_{2}$ to $\mathrm{CH}_{3} \mathrm{OH}$ is rapid under hydrothermal conditions while reduction of $\mathrm{CH}_{3} \mathrm{OH}$ to $\mathrm{CH}_{4}$ is comparatively slow, but does proceed at measurable rates. Aqueous reduction of $\mathrm{CO}_{2}$ to $\mathrm{CH}_{4}$ via $\mathrm{CH}_{3} \mathrm{OH}$ thus represents a likely pathway to form significant quantities of $\mathrm{CH}_{4}$ in unsedimented seafloor hydrothermal systems. Despite slower kinetics than mineral-catalyzed mechanisms, $\mathrm{CH}_{4}$ production may be associated with maximal $\mathrm{H}_{2}$ production during serpentinization at $200-315^{\circ} \mathrm{C}$ due to the enhanced stability of methanol at these temperatures relative to much hotter subsurface conditions. By addition of $\mathrm{H}_{2} \mathrm{~S}$, the potential role of $\mathrm{CH}_{3} \mathrm{SH}$ in $\mathrm{CH}_{4}$ formation appears to be limited as direct reduction of $\mathrm{CO}_{2}$ to the former did not readily occur. The aqueous reduction of $\mathrm{CO}_{2}$ to $\mathrm{CH}_{4}$ appears to be an unavoidable consequence of the strong chemical and thermal gradients present in seafloor hydrothermal systems. 


\section{ACKNOWLEDGEMENTS}

I would like to thank Dr. P. Saccocia for the initial setup of the experiment in 2003. I would also like to thank S. Sylva for his analytical expertise and assistance with instrumentation and sampling. This work was supported by the National Science Foundation grant OCE-0136954. 
Table 2.1

Concentrations of aqueous species measured during heating at $325-300^{\circ} \mathrm{C}$ and $35 \mathrm{MPa}$

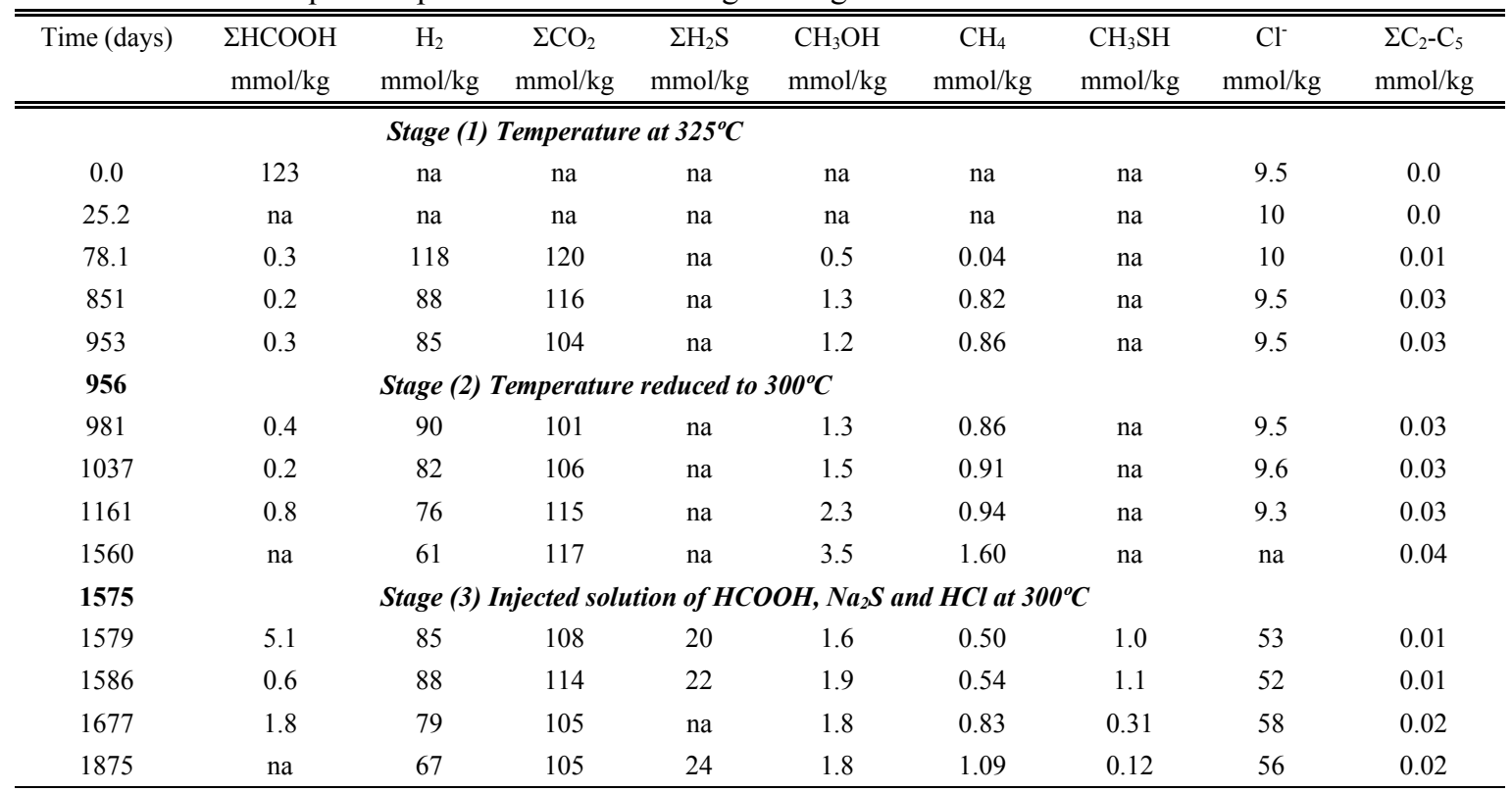

na $=$ not analyzed

$\Sigma \mathrm{C}_{2}-\mathrm{C}_{5}=$ Sum of straight chain alkane and alkene compounds with carbon numbers 2 to 5

The analytical uncertainty of all dissolved species measurements is estimated at $\pm 5 \%(2 \sigma)$ 
Table 2.2.

Predicted concentrations of methanol in equilibrium with measured $\mathrm{CO}_{2}$ and $\mathrm{H}_{2}$ for two representative fluids from high temperature ultramafic-hosted hydrothermal systems

\begin{tabular}{|c|c|c|c|c|c|}
\hline Vent Site & $\begin{array}{l}\text { Temp. } \\
\left({ }^{\circ} \mathrm{C}\right) \\
\end{array}$ & $\begin{array}{c}\text { Depth } \\
\text { (m) }\end{array}$ & $\begin{array}{c}\mathrm{CO}_{2} \\
(\mathrm{mM})\end{array}$ & $\begin{array}{c}\mathbf{H}_{2} \\
(\mathbf{m M}) \\
\end{array}$ & $\begin{array}{c}\mathrm{CH}_{3} \mathrm{OH}^{*} \\
(\mu M)\end{array}$ \\
\hline $\begin{array}{c}\text { Logatchev } \\
\left(14^{\circ} 45^{\prime} \mathrm{N}, \text { MAR }\right)\end{array}$ & 350 & 3000 & 10.1 & 12.0 & 0.025 \\
\hline $\begin{array}{c}\text { Rainbow } \\
\left(36^{\circ} 14^{\prime} \mathbf{N}, \text { MAR }\right)\end{array}$ & 365 & 2300 & 16 & 16 & 0.23 \\
\hline
\end{tabular}

Temperatures are measured exit temperatures

MAR $=$ Mid-Atlantic Ridge, $*$ = predicted

Data from Charlou et al. (2002) 


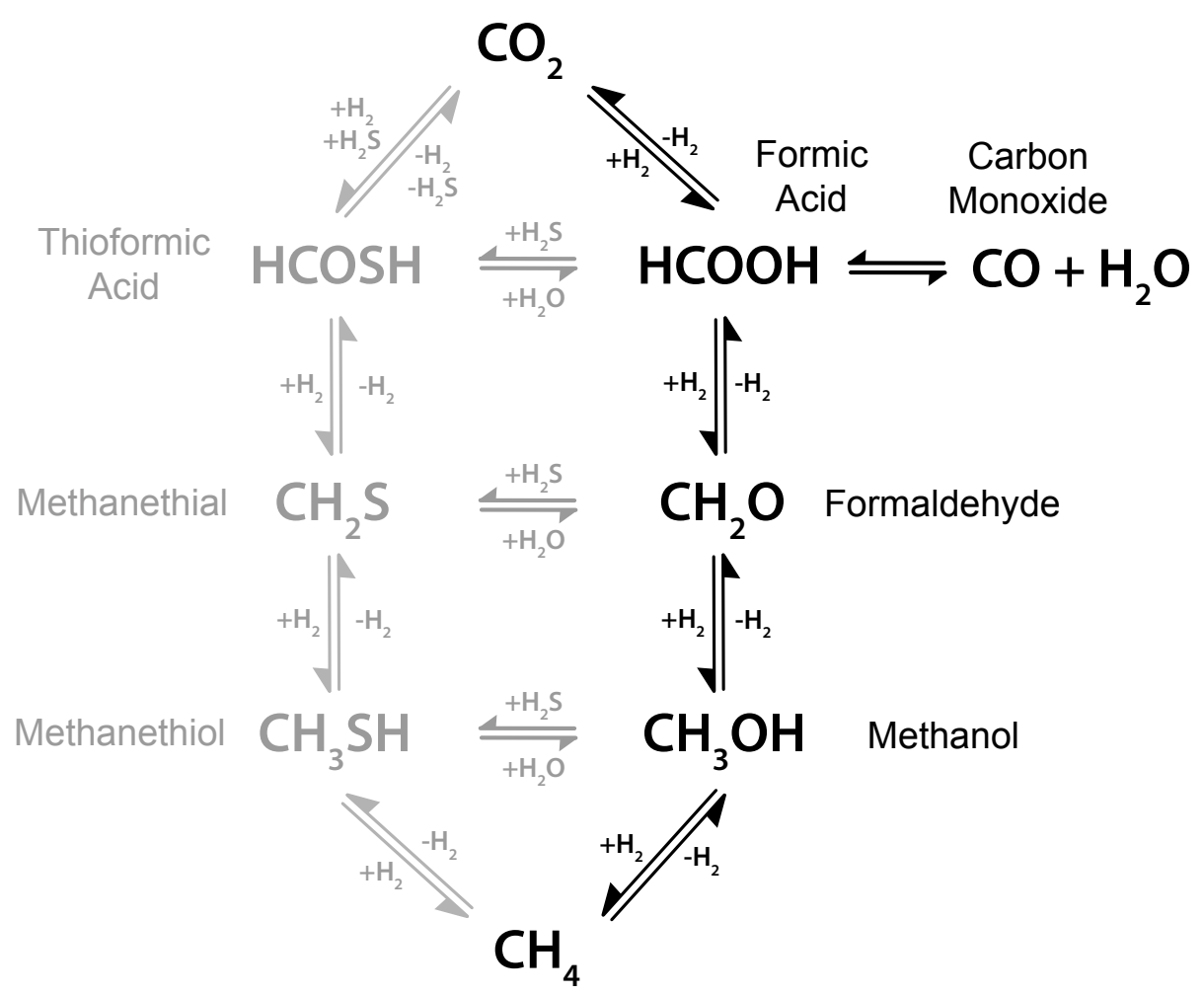

Figure 2.1. Model for the sequential aqueous reduction of $\mathrm{CO}_{2}$ to $\mathrm{CH}_{4}$ by $\mathrm{H}_{2}$ via a series of intermediate oxidation state single carbon compounds. The pathway in black is that proposed by SEEWALD et al. (2006) for the system $\mathrm{C}-\mathrm{O}-\mathrm{H}$ (excluding carbon-carbon bonds), while that in grey represents an alternative possible reaction pathway with S-bearing intermediates in the analogous C-O-S-H system. Because of the addition of $\mathrm{S}$, redox independent substitution reactions between S-bearing and oxygenated species with similar carbon oxidation states are also theoretically possible. Carbonyl sulfide (COS) and carbon disulfide $\left(\mathrm{CS}_{2}\right)$ are not included as they do not represent a change in carbon oxidation state from that of $\mathrm{CO}_{2}$. 


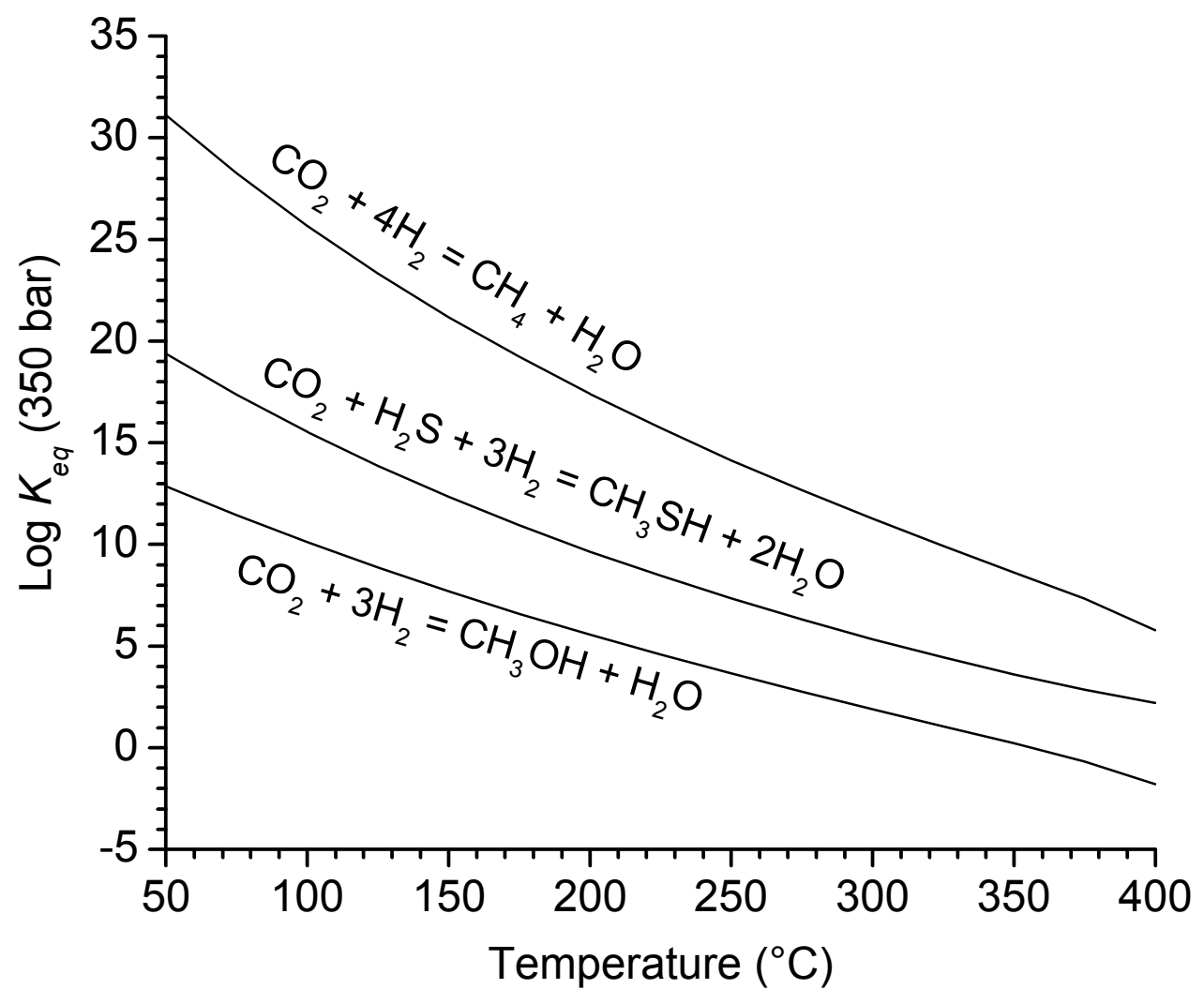

Figure 2.2. Temperature dependence of the equilibrium constants $\left(K_{e q}\right)$ for $\mathrm{CH}_{3} \mathrm{OH}, \mathrm{CH}_{3} \mathrm{SH}$ and $\mathrm{CH}_{4}$ formation by overall $\mathrm{CO}_{2}$ reduction. All reactions are favored to proceed from right to left as written at lower temperatures, with $\mathrm{CH}_{4}$ formation exhibiting stronger temperature dependency than $\mathrm{CH}_{3} \mathrm{OH}$ and $\mathrm{CH}_{3} \mathrm{SH}$ formation. Requisite thermodynamic data for the construction of this figure were taken from the SUPCRT92 database (JOHNSON et al., 1992) with additional data from AMEND and HELGESON (1997), SHOCK and HELgESON (1990) and SCHULte and ROgERS (2004). 


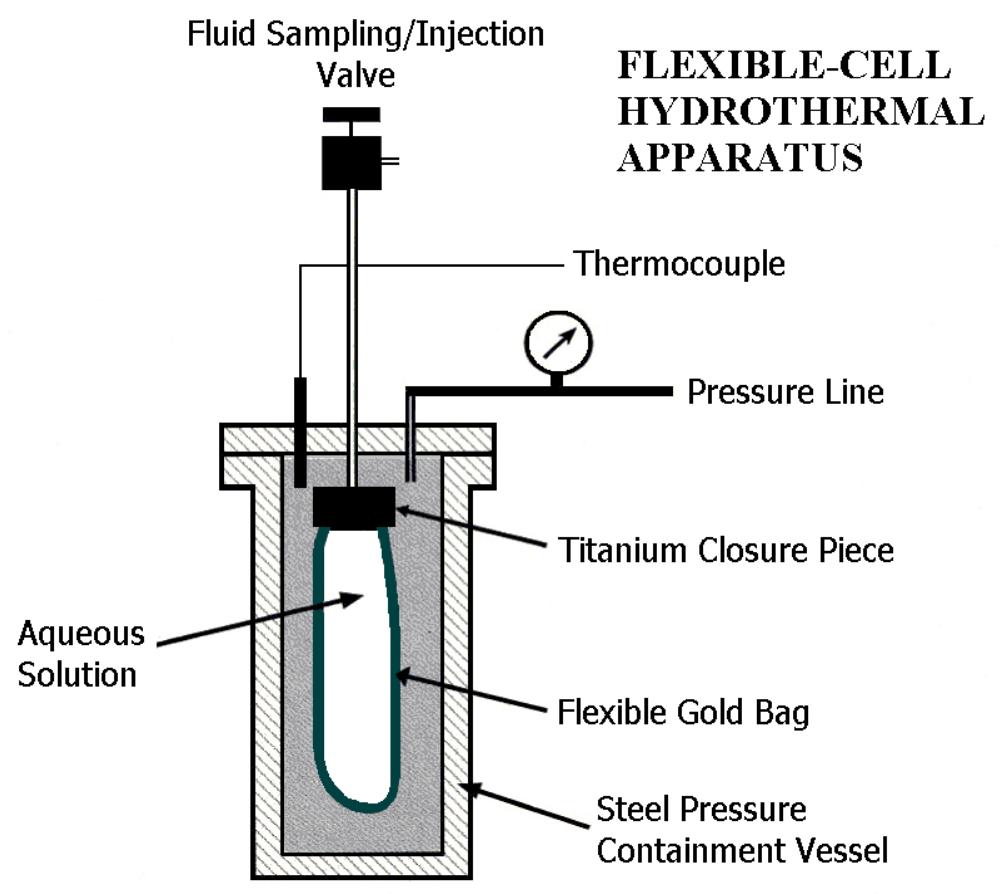

Figure 2.3. Schematic of the SEYFRIED (1987) design of flexible-cell hydrothermal reactor and pressure containment vessel. The entire apparatus is kept at desired conditions inside a temperature-controlled furnace. The in situ temperature is monitored using thermocouple temperature probes adjacent to the pressure vessel. Pressure is adjusted using a HPLC pump/bleed system attached to the pressure line. Adapted from MCCOLLOM and SEEWALD (2001). 

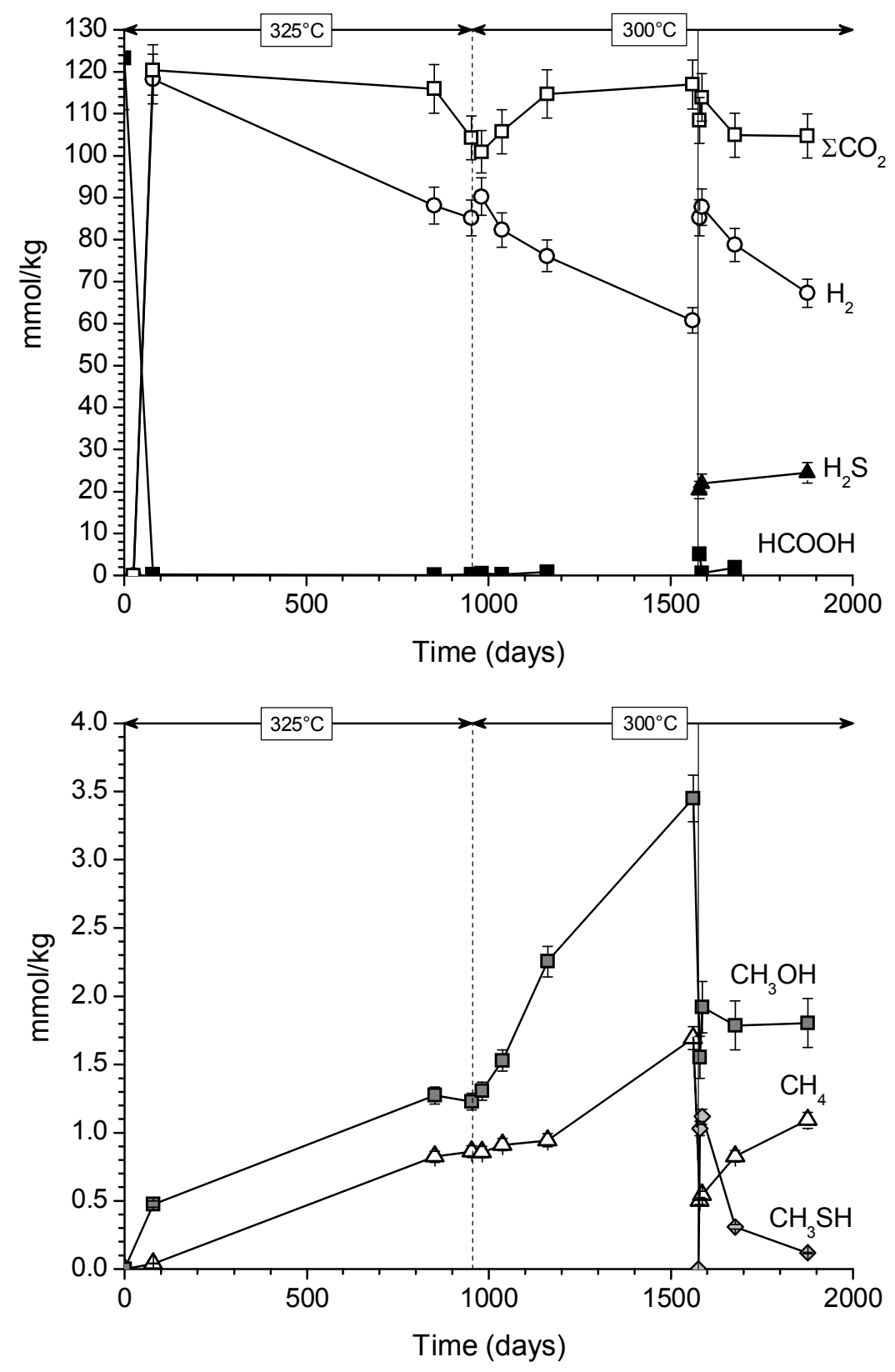

Figure 2.4. Measured concentrations of dissolved species as a function of time during the $325^{\circ} \mathrm{C}$ and $300^{\circ} \mathrm{C}$ phases of the experiment. The dashed vertical line at 956 days indicates the perturbation of equilibrium by rapid cooling of the pressure vessel. The solid vertical line at 1575 days represents injection of a solution of $\mathrm{H}_{2} \mathrm{~S}, \mathrm{H}^{13} \mathrm{COOH}$ and $\mathrm{NaCl}$. 2s analytical uncertainties are plotted for selected species. $\mathrm{CH}_{4}$ accumulation in solution was initially slow but increased to a constant rate by the end of the $325^{\circ} \mathrm{C}$ phase. 
Normal Abundance:

${ }^{13} \mathrm{C}$-labelled:
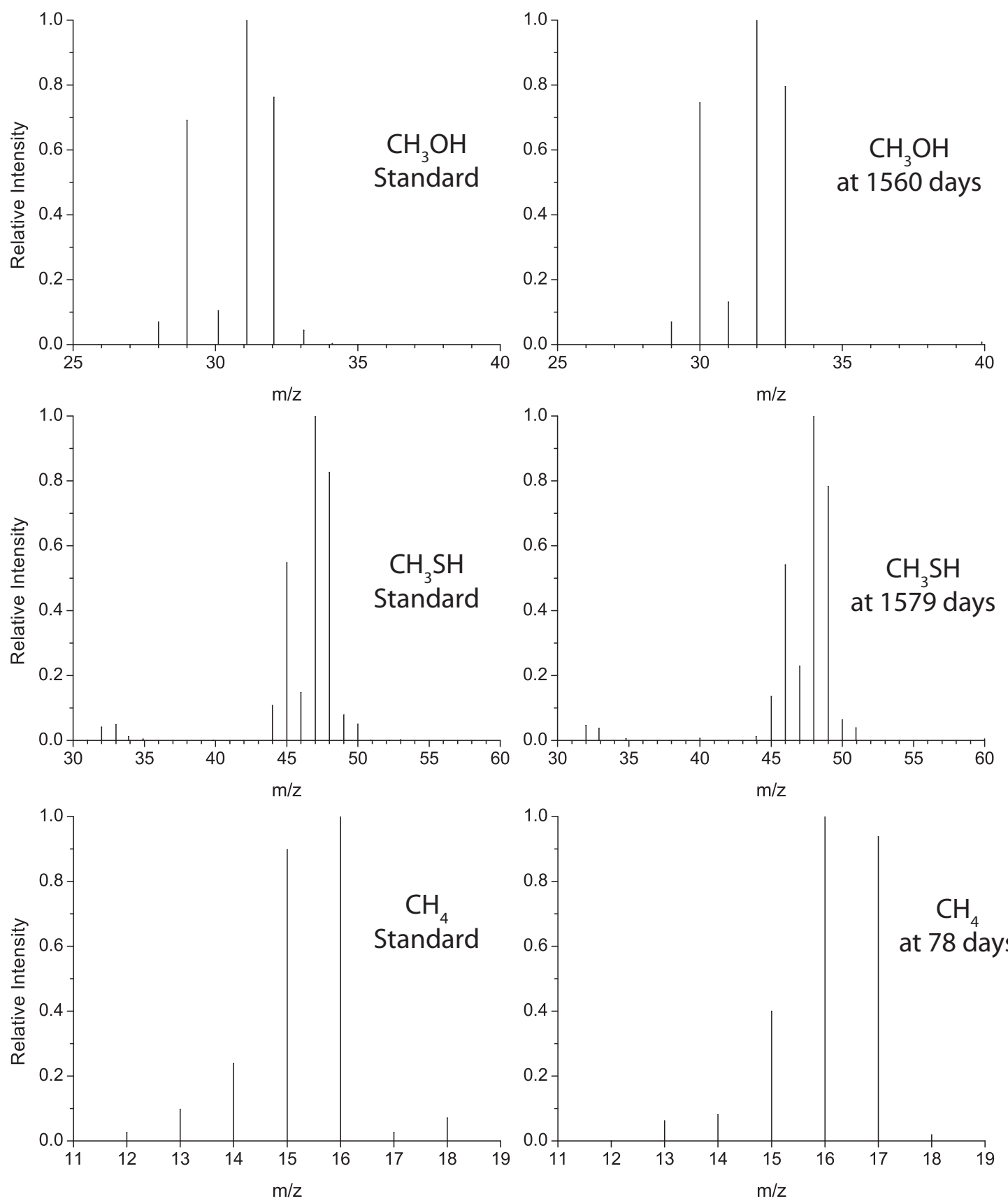

Figure 2.5. Mass spectrum of natural ${ }^{13} \mathrm{C}$ abundance $\mathrm{CH}_{3} \mathrm{OH}, \mathrm{CH}_{3} \mathrm{SH}$ and $\mathrm{CH}_{4}$ standards compared with ${ }^{13} \mathrm{C}$-labeled forms in experimental samples. Extensive incorporation of the ${ }^{13} \mathrm{C}$ label into all three species, as evidenced by the $\mathrm{m} / \mathrm{z}$ shift of 1 , necessitates that production of both compounds must have occurred via the reduction of labeled $\mathrm{HCOOH}$ and/or $\mathrm{CO}_{2}$. 
Figure 2.6. Thermodynamic affinities for the production of $\mathrm{CH}_{3} \mathrm{OH}\left(A_{\text {Methanol }}\right), \mathrm{CH}_{3} \mathrm{SH}\left(A_{C H 3 S H}\right)$ and $\mathrm{CH}_{4}$ ( $\left.A_{\text {Methane }}\right)$ by the overall reactions shown in Figure 2.2 during the experiment. The dashed vertical line at 956 days represents the drop in temperature from $325^{\circ} \mathrm{C}$ to $300^{\circ} \mathrm{C}$ and the solid vertical line at 1575 days represents injection of a solution containing $\mathrm{H}^{13} \mathrm{COOH}, \mathrm{NaCl}$ and $\mathrm{H}_{2} \mathrm{~S}$. $A_{\text {Methane }}$ remained large throughout the experiment. In contrast, $A_{\text {Methanol }}$ appears to have achieved equilibrium $(A=0 \pm 4 \mathrm{~kJ} / \mathrm{mol})$ on the timescales of all three stages. $A_{C H 3 S H}$ (black triangles, right axis) increased gradually during the last stage of the experiment. Requisite thermodynamic data for the construction of this figure were taken from the SUPCRT92 database (JOHNSON et al., 1992) with additional data from SHOCK and HELGESON (1990), AMEND and HELgESON (1997) and SHUlte and Rogers (1990). 


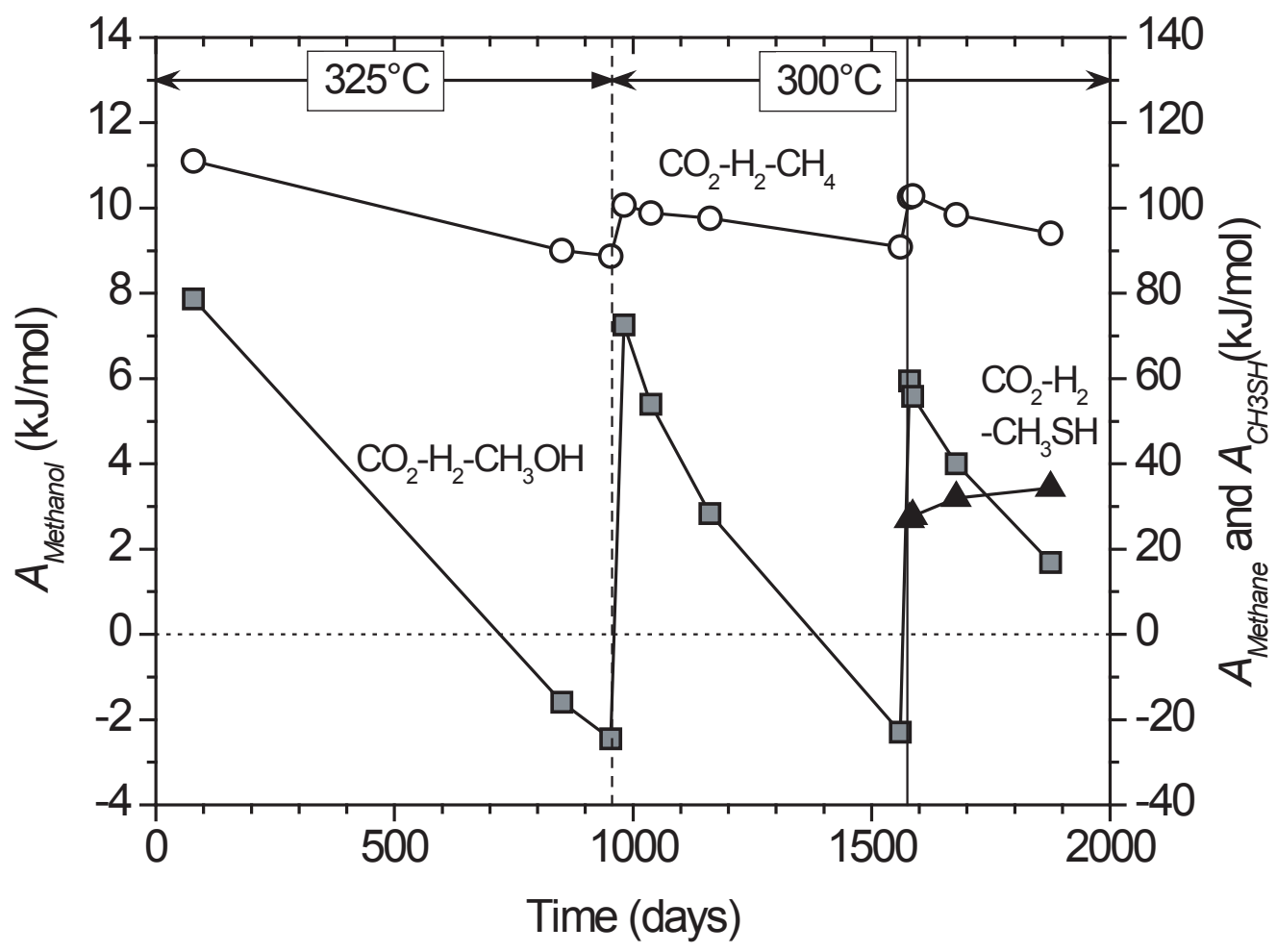

Figure 2.6. 
Figure 2.7. Equilibrium abundances of aqueous species as a function of $\mathrm{pH}$ at $35 \mathrm{MPa}$ for a model solution initially containing $120 \mathrm{mmol} / \mathrm{kg}$ total $\mathrm{CO}_{2}$ and $\mathrm{H}_{2}$ at temperatures of $(\mathbf{A}), 325^{\circ} \mathrm{C}$, and $(\mathbf{B}), 300^{\circ} \mathrm{C}$, assuming metastable equilibrium between $\mathrm{CO}_{2}$ (and the carbonate system), $\mathrm{H}_{2}, \mathrm{CO}, \mathrm{HCOOH}, \mathrm{HCOO}^{-}, \mathrm{CH}_{2} \mathrm{O}$ and $\mathrm{CH}_{3} \mathrm{OH}$ in the absence of $\mathrm{CH}_{4}$ formation. Diagrams (C), $325^{\circ} \mathrm{C}$ and (D), $300^{\circ} \mathrm{C}$, allows $\mathrm{CO}_{2}$ to equilibrate with $\mathrm{CH}_{4}$ in addition to the species above. The dashed vertical lines in (A) and (B) represent the calculated in situ fluid composition of the model solution at the specified temperature. For comparison, measured concentrations of $\mathrm{CO}_{2}$ (grey squares), $\mathrm{H}_{2}$ (open circles) and $\mathrm{CH}_{3} \mathrm{OH}$ (black circles) at the end of Stage (1), (A), and Stage (2), (B), are shown. (E) represents the same reaction system and conditions as (B), except for the addition of $20 \mathrm{mmol} / \mathrm{kg}$ total $\mathrm{H}_{2} \mathrm{~S}$, and the introduction of $\mathrm{CH}_{3} \mathrm{SH}$ formation by the overall reaction shown in Figure 2.2. The measured $\mathrm{CH}_{3} \mathrm{SH}$ concentration at the end of Stage (3) is shown (grey circle). $\mathrm{H}_{2} \mathrm{~S} / \mathrm{HS}^{-}$dissociation is included, but dissociation of $\mathrm{CH}_{3} \mathrm{SH}$ is not included due to a lack of thermodynamic data for $\mathrm{CH}_{3} \mathrm{~S}^{-}$. Requisite thermodynamic data for the construction of this figure were taken from the SUPCRT92 database JOHNSON et al. (1992), with additional data from SHOCK (1995), SHOCK and HELGESON (1990) and SCHULTE and ROGERS (2004). 

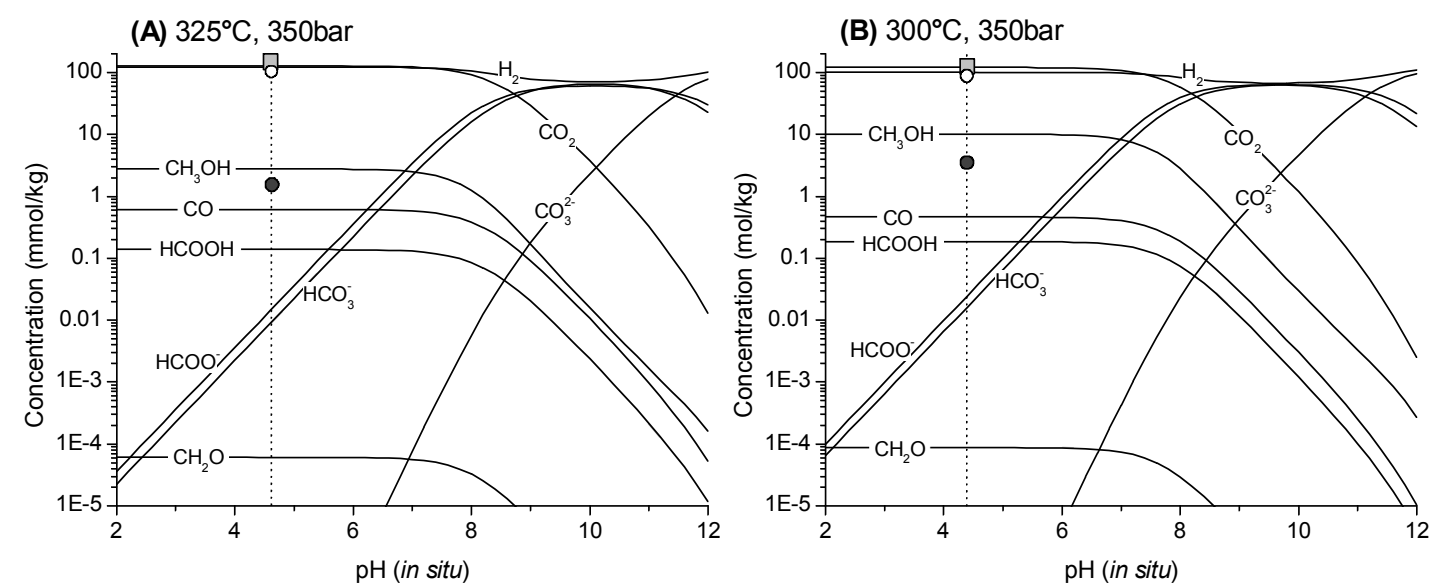

(C) $325^{\circ} \mathrm{C}, 350 \mathrm{bar}$
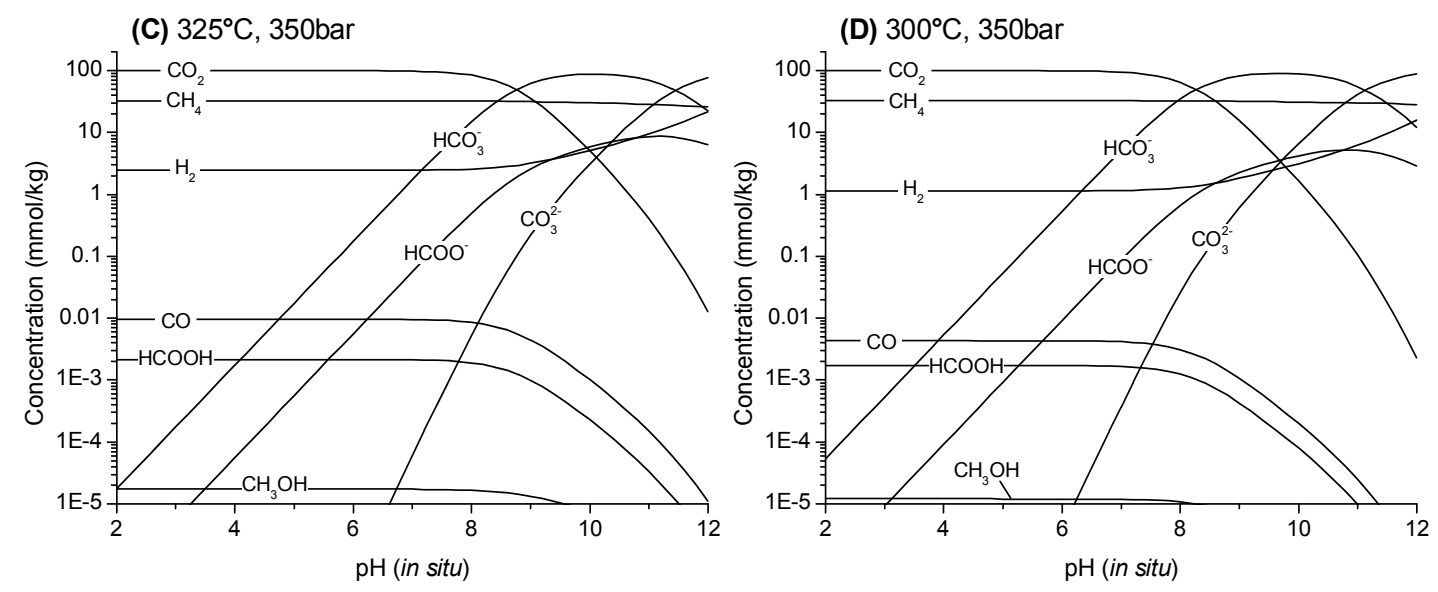

(E) $300^{\circ} \mathrm{C}, 350 \mathrm{bar}$

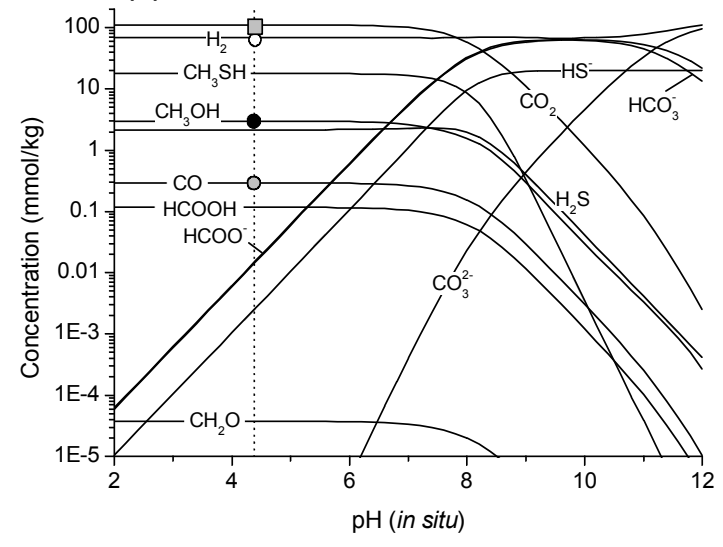

Figure 2.7 


\section{REFERENCES}

Abrajano, T. A., Sturchio, N. C., Bohlke, J. K., Lyon, G. L., Poreda, R. J., and Stevens, C. M. (1988) Methane Hydrogen Gas Seeps, Zambales Ophiolite, Philippines - Deep Or Shallow Origin. Chemical Geology 71(1-3), 211-222.

Abrajano, T. A., Sturchio, N. C., Kennedy, B. M., Lyon, G. L., Muehlenbachs, K., and BOHLKE, J. K. (1990) Geochemistry Of Reduced Gas Related To Serpentinization Of The Zambales Ophiolite, Philippines. Applied Geochemistry 5(5-6), 625-630.

Allen, D. E. and SEYFrIED, W. E. (2004) Serpentinization and heat generation: Constraints from Lost City and Rainbow hydrothermal systems. Geochimica et Cosmochimica Acta 68(6), $1347-1354$.

Anslyn, E.V. and Dougherty, D.A. (2005) Modern Physical Organic Chemistry. University Science.

AMEND, J. P. and HELGESON, H. C. (1997) Group additivity equations of state for calculating the standard molal thermodynamic properties of aqueous organic species at elevated temperatures and pressures. Geochimica et Cosmochimica Acta 61(1), 11-46.

Anderson, G. (2005) Thermodynamics of Natural Systems. Cambridge University Press.

Anderson, R. B. (1984) The Fischer-Tropsch Reaction. Academic Press.

Baross, J. A. and Hoffman, S. E. (1985) Submarine Hydrothermal Vents And Associated Gradient Environments As Sites For The Origin And Evolution Of Life. Origins Of Life And Evolution Of The Biosphere 15(4), 327-345.

BARoss, J. A. and DEMING, J. W. (1995) Growth at high temperatures: Isolation and taxonomy, physiology and ecology. In: The Microbiology of Deep-Sea Hydrothermal Vents, (Ed: D. M. Karl), CRC Press. pp. 169-218. 
Bell, J. L. S., PAlmer, D. A., BARnes, H. L., and DRUMmond, S. E. (1994) ThermalDecomposition Of Acetate: III. Catalysis By Mineral Surfaces. Geochimica et Cosmochimica Acta 58(19), 4155-4177.

Berndt, M. E., Allen, D. E., and SEyfried, W. E. (1996) Reduction of $\mathrm{CO}_{2}$ during serpentinization of olivine at $300{ }^{\circ} \mathrm{C}$ and 500 bar. Geology 24(4), 351-354.

BRAdLEY, A. S., HAYES, J. M., and SuMMONS, R. E. (2009) Extraordinary ${ }^{13}$ C enrichment of diether lipids at the Lost City Hydrothermal Field indicates a carbon-limited ecosystem. Geochimica et Cosmochimica Acta 73(1), 102-118.

Charlou, J. L. and Donval, J. P. (1993) Hydrothermal Methane Venting Between $12^{\circ} \mathrm{N}$ And $26^{\circ} \mathrm{N}$ Along The Mid-Atlantic Ridge. Journal Of Geophysical Research-Solid Earth 98(B6), 9625-9642.

Charlou, J. L., Donval, J. P., Fouquet, Y., Jean-Baptiste, P., and Holm, N. (2002) Geochemistry of high $\mathrm{H}_{2}$ and $\mathrm{CH}_{4}$ vent fluids issuing from ultramafic rocks at the Rainbow hydrothermal field (36²14'N, MAR). Chemical Geology 191(4), 345-359.

Charlou, J. L., Fouquet, Y., Bougault, H., Donval, J. P., Etoubleau, J., Jean-Baptiste, P., DAPOigny, A., Appriou, P., and RONA, P. A. (1998) Intense $\mathrm{CH}_{4}$ plumes generated by serpentinization of ultramafic rocks at the intersection of the $15^{\circ} 20^{\prime} \mathrm{N}$ fracture zone and the Mid-Atlantic Ridge. Geochimica et Cosmochimica Acta 62(13), 2323-2333.

Corliss, J. B., BARoss, J. A., and HoffMAN, S. E. (1981) An hypothesis concerning the relationship between submarine hot springs and the origin of life on Earth. Oceanologica Acta 4(Supplement), 59-69.

COWEN, J. P., WEN, X. Y., and POPP, B. N. (2002) Methane in aging hydrothermal plumes. Geochimica et Cosmochimica Acta 66(20), 3563-3571.

DE Duve, C. (1991) Blueprint for a Cell: The Nature and Origin of Life. N. Patterson. 
FISHER, A. T. (2003) Geophysical constraints on hydrothermal circulation: observations and models. In: Dahlem Workshop Report: Energy and Mass Transfer in Marine Hydrothermal Systems, (Ed: P. E. Halbach, V. Tunnicliffe, and J. R. Hein), 89, Dahlem University Press. pp. 29-52.

FoustoukOs, D. I. and SEYFRIED, W. E. (2004) Hydrocarbons in hydrothermal vent fluids: The role of chromium-bearing catalysts. Science 304(5673), 1002-1005.

FoustoukOs, D. I., SAVOV, I. P., and JANECKY, D. R. (2008) Chemical and isotopic constraints on water/rock interactions at the Lost City hydrothermal field, $30^{\circ} \mathrm{N}$ Mid-Atlantic Ridge. Geochimica et Cosmochimica Acta 72(22), 5457-5474.

Fu, Q., SHerwood Lollar, B., Horita, J., LACRAMPe-Couloume, G., and Seyfried, W. (2007) Abiotic formation of hydrocarbons under hydrothermal conditions: Constraints from chemical and isotopic data. Geochimica et Cosmochimica Acta 71(8), 1982-1998.

GArrels, R. M. and Christ, C. L. (1965) Solutions, Minerals, and Equilibria. Harper \& Row.

Glein, C. R., Zolotov, M. Y., and SHOck, E. L. (2008) The oxidation state of hydrothermal systems on early Enceladus. Icarus 197(1), 157-163.

GLeIN, C. R., DESCH, S. J., and SHOCK, E. L. (2009) The absence of endogenic methane on Titan and its implications for the origin of atmospheric nitrogen. Icarus 204(2), 637-644.

HAYATSU, R. and ANDERS, E. (1981) Organic compounds in meteorites and their origins. Topics in Current Chemistry 99, 1-37.

HeINEN, W. and LAUWERS, A. M. (1996) Organic sulfur compounds resulting from the interaction of iron sulfide, hydrogen sulfide and carbon dioxide in an anaerobic aqueous environment. Origins Of Life And Evolution Of The Biosphere 26(2), 131-150. 
Holloway, J. R. and O'DAY, P. A. (2000) Production of $\mathrm{CO}_{2}$ and $\mathrm{H}_{2}$ by diking-eruptive events at mid-ocean ridges: Implications for abiotic organic synthesis and global geochemical cycling. International Geology Review 42(8), 673-683.

HORITA, J. and BERNDT, M. E. (1999) Abiogenic methane formation and isotopic fractionation under hydrothermal conditions. Science 285(5430), 1055-1057.

HUBer, C. and WACHTERShauser, G. (1997) Activated acetic acid by carbon fixation on (Fe,Ni)S under primordial conditions. Science 276(5310), 245-247.

Johnson, J. W., OElKers, E. H., and HELgESON, H. C. (1992) SUPCRT92 - A software package for calculating the standard molal thermodynamic properties of minerals, gases, aqueous species, and reactions from 1 to 5000 bar and 0 to $1000^{\circ} \mathrm{C}$. Computers \& Geosciences 18(7), 899-947.

KADKO, D. and MoORE, W. (1988) Radiochemical Constraints On The Crustal Residence Time Of Submarine Hydrothermal Fluids - Endeavor Ridge. Geochimica et Cosmochimica Acta 52(3), 659-668.

KADKO, D. and BUTTERFIELD, D. A. (1998) The relationship of hydrothermal fluid composition and crustal residence time to maturity of vent fields on the Juan de Fuca Ridge. Geochimica et Cosmochimica Acta 62(9), 1521-1533.

Kelley, D. S. and FruH-GreEN, G. L. (1999) Abiogenic methane in deep-seated mid-ocean ridge environments: insights from stable isotope analyses. Journal of Geophysical Research, [Solid Earth] 104(B5), 10439-10460.

Kelley, D. S., BARoss, J. A., and Delaney, J. R. (2002) Volcanoes, fluids, and life at midocean ridge spreading centers. Annual Review Of Earth And Planetary Sciences 30, $385-$ 491. 
Kelley, D. S., LiLley, M. D., and FrÜH-GreEN, G. L. (2004) Volatiles in submarine environments: food for life. In: The Subseafloor Biosphere at Mid-Ocean Ridges, (Ed: W. S. D. Wilcock, E. F. DeLong, D. S. Kelley, J. A. Baross, and S. C. Cary), AGU Monograph, 144, American Geophysical Union. pp. 167-189.

Kelley, D. S., Karson, J. A., Blackman, D. K., Fruh-Green, G. L., Butterfield, D. A., Lilley, M. D., Olson, E. J., SchrenK, M. O., Roe, K. K., Lebon, G. T. et al. (2001) An off-axis hydrothermal vent field near the Mid-Atlantic Ridge at $30^{\circ} \mathrm{N}$. Nature 412(6843), 145-149.

Klein, F., BACH, W., Jons, N., McCollom, T., Moskowitz, B., and Berquo, T. (2009) Iron partitioning and hydrogen generation during serpentinization of abyssal peridotites from 15 degrees N on the Mid-Atlantic Ridge. Geochimica et Cosmochimica Acta 73(22), $6868-6893$

LEIF, R. N. and SimONEIT, B. R. T. (2000) The role of alkenes produced during hydrous pyrolysis of a shale. Organic Geochemistry 31(11), 1189-1208.

LiU, Z. T., ZHOU, J. L., and Zhang, B. J. (1994) Poisoning Of Iron Catalyst By Cos In Syngas For Fischer-Tropsch Synthesis. Journal Of Molecular Catalysis 94(2), 255-261.

Luther, G. W. (2004) Activation of Diatomic and Triatomic Molecules for the Synthesis of Organic Compounds: Metal Catalysis at the Subseafloor Biosphere. In: The Subseafloor Biosphere at Mid-Ocean Ridges, AGU Monograph,(Ed: W. S. D. Wilcock, E. F. DeLong, D. S. Kelley, J. A. Baross, and S. C. Cary), 144, American Geophysical Union. pp. 191198.

MARTIN, W. and RuSSELL, M. J. (2006) Review: On the origin of biochemistry at an alkaline hydrothermal vent. Philosophical Transactions Of The Royal Society Of London Series 
B: Biological Sciences, Page FirstCite, DOI 10.1098/rstb.2006.1881, URL:

http://dx.doi.org/10.1098/rstb.2006.1881.

Martin, W., BARoss, J., Kelley, D., and Russell, M. J. (2008) Hydrothermal vents and the origin of life. Nature Reviews Microbiology 6(11), 805-814.

McCollom, T. M. and SeEwald, J. S. (2001) A reassessment of the potential for reduction of dissolved $\mathrm{CO} 2$ to hydrocarbons during serpentinization of olivine. Geochimica et Cosmochimica Acta 65(21), 3769-3778.

MCCollom, T. M. and SeEwald, J. S. (2003a) Experimental constraints on the hydrothermal reactivity of organic acids and acid anions: I. Formic acid and formate. Geochimica et Cosmochimica Acta 67(19), 3625-3644.

MCCollom, T. M. and SeEWALD, J. S. (2003b) Experimental study of the hydrothermal reactivity of organic acids and acid anions: II. Acetic acid, acetate, and valeric acid. Geochimica et Cosmochimica Acta 67(19), 3645-3664.

McCollom, T. M. and SeEwald, J. S. (2006) Carbon isotope composition of organic compounds produced by abiotic synthesis under hydrothermal conditions. Earth and Planetary Science Letters 243(1-2), 74-84.

McCollom, T. M. and SeEwald, J. S. (2007) Abiotic synthesis of organic compounds in deepsea hydrothermal environments. Chemical Reviews 107, 382-401.

MCCOLlOM, T. M. and BACH, W. G. (2009) Thermodynamic constraints on hydrogen generation during serpentinization of ultramafic rocks. Geochimica et Cosmochimica Acta 73(3), $856-875$.

MiLlER, S. L. and BADA, J. L. (1988) Submarine hot springs and the origin of life. Nature 334, 609-611. 
Mumma, M. J., Villanueva, G. L., Novak, R. E., Hewagama, T., Bonev, B. P., DiSanti, M. A., Mandell, A. M., and Smith, M. D. (2009) Strong Release of Methane on Mars in Northern Summer 2003. Science 323(5917), 1041-1045.

Proskurowski, G., Lilley, M. D., Seewald, J. S., Fruh-Green, G. L., Olson, E. J., LuPton, J. E., SYlVA, S. P., and Kelley, D. S. (2008) Abiogenic hydrocarbon production at Lost City hydrothermal field. Science 319(5863), 604-607.

Rhodes, C., Riddel, S. A., West, J., Williams, B. P., and Hutchings, G. J. (2000) The lowtemperature hydrolysis of carbonyl sulfide and carbon disulfide: a review. Catalysis Today 59(3-4), 443-464.

RUSHDI, A. I. and SIMONEIT, B. R. (2001) Lipid formation by aqueous Fischer-Tropsch-type synthesis over a temperature range of 100 to $400^{\circ} \mathrm{C}$. Origins of life and evolution of the biosphere 31(1-2), 103-118.

Russell, M. J. and HALl, A. J. (2006) The onset and early evolution of life. In: Evolution of Early Earth's Atmosphere, Hydrosphere, and Biosphere - Constraints from Ore Deposits: Geological Society of America Memoir 198, (Ed: S. E. Kesler and H. Ohmoto), Geological Society of America. pp. 1-32.

Schulte, M. and SHOcK, E. (1995) Thermodynamics Of Strecker Synthesis In Hydrothermal Systems. Origins Of Life And Evolution Of The Biosphere 25(1-3), 161-173.

SCHUlte, M. D. and Rogers, K. L. (2004) Thiols in hydrothermal solution: standard partial molal properties and their role in the organic geochemistry of hydrothermal environments. Geochimica et Cosmochimica Acta 68(5), 1087-1097.

SEEWALD, J. S. (2001) Aqueous geochemistry of low molecular weight hydrocarbons at elevated temperatures and pressures: Constraints from mineral buffered laboratory experiments. Geochimica et Cosmochimica Acta 65(10), 1641-1664. 
SEewald, J. S., Zolotov, M. Y., and MCCollom, T. (2006) Experimental investigation of single carbon compounds under hydrothermal conditions. Geochimica et Cosmochimica Acta 70(2), 446-460.

SEYFRIED, W., D.R. JANECKY AND M.E. BERNDT (1987) Rocking autoclaves for hydrothermal experiments II: The flexible reaction-cell system. In: Hydrothermal Experimental Techniques, (Ed: G. C. Ulmer and H. L. Barnes), Wiley. pp. 216-239.

Sherwood, B., Fritz, P., Frape, S. K., Macko, S. A., Weise, S. M., and Welhan, J. A. (1988) Methane Occurrences In The Canadian Shield. Chemical Geology 71(1-3), 223-236.

SHOCK, E. L. (1992) Chemical Environments Of Submarine Hydrothermal Systems. Origins Of Life And Evolution Of The Biosphere 22(1-4), 67-107.

SHOCK, E. L. (1995) Organic-Acids In Hydrothermal Solutions - Standard Molal Thermodynamic Properties Of Carboxylic-Acids And Estimates Of Dissociation-Constants At HighTemperatures And Pressures. American Journal Of Science 295(5), 496-580.

SHOCK, E. L. and HELGESON, H. C. (1990) Calculation of the thermodynamic and transport properties of aqueous species at high pressures and temperatures: Standard partial molal properties of organic species. Geochimica et Cosmochimica Acta 54(4), 915-945.

SHock, E. L. and SCHulte, M. D. (1998) Organic synthesis during fluid mixing in hydrothermal systems. Journal Of Geophysical Research-Planets 103(E12), 28513-28527.

Voglesonger, K. M., Holloway, J. R., Dunn, E. E., Dalla-Betta, P. J., and O'DAy, P. A. (2001) Experimental abiotic synthesis of methanol in seafloor hydrothermal systems during diking events. Chemical Geology 180(1-4), 129-139.

VON DAMM, K. L. (1995) Controls on the chemistry and temporal variability of seafloor hydrothermal systems. In: Seafloor Hydrothermal Systems: Physical, Chemical, Biological, and Geological Interactions, (Ed: S. E. Humphris, R. A. Zierenberg, L. S. 
Mullineaux, and R. E. Thomson), AGU Monograph, 91, American Geophysical Union. pp. 222-247.

WeLhan, J. A. (1988) Origins of methane in hydrothermal systems. Chemical Geology 71(1-3), 183-198. 


\title{
CHAPTER 3
}

\section{Insights into the origin of methanethiol in seafloor hydrothermal fluids}

\begin{abstract}
Abiotic (non-biological) synthesis of methanethiol $\left(\mathrm{CH}_{3} \mathrm{SH}\right)$ in hydrothermal solutions is considered an important first step in the emergence of primitive chemoautotrophism as the earliest form of life. However, little is known about the origin and distribution of $\mathrm{CH}_{3} \mathrm{SH}$ in seafloor hydrothermal fluids. This chapter reports the first known measurements of $\mathrm{CH}_{3} \mathrm{SH}$ concentrations in 'black smoker' fluids collected from ultramafic-, basalt- and sediment-hosted settings. Concentrations in relatively oxidizing $\left(\mathrm{H}_{2}\right.$-poor) basalt-hosted fluids (TAG, Lucky Strike, $9^{\circ} 50^{\prime} \mathrm{N}$ East Pacific Rise) are comparable to those in more reducing ultramafic systems (Lost City, Rainbow) despite differences in dissolved $\mathrm{H}_{2}$ concentrations of several orders of magnitude. When considered in a thermodynamic context, this distribution is therefore inconsistent with formation of $\mathrm{CH}_{3} \mathrm{SH}$ by abiotic $\mathrm{CO}_{2}$ reduction. $\mathrm{CH}_{3} \mathrm{SH}$ abundances in Guaymas Basin vent fluids indicate that thermogenic sources (pyrolysis of sedimentary organic matter) are possible, while enrichments in low temperature fluids at Rainbow and $9^{\circ} 50^{\prime} \mathrm{N}$ suggest that fluidmicrobe interactions may be a source to sediment-starved systems. In the absence of microbial/thermogenic sources, the only abiotic pathway that could account for $\mathrm{CH}_{3} \mathrm{SH}$ distributions in high temperature black smoker fluids is partial oxidation of $\mathrm{CH}_{4}$ with $\mathrm{H}_{2} \mathrm{~S}$. The latter would represent a fundamental paradigm shift in our understanding of abiotic synthesis in hydrothermal systems, which is typically viewed as a solely reductive process.
\end{abstract}




\section{INTRODUCTION}

Since their discovery, seafloor hydrothermal fluids have been proposed as a source of abiotic organic compounds necessary for early life to emerge on a prebiotic (Hadean-Archaean) Earth (CORLiss et al., 1981; BAROSS and HOFFMAN, 1985; HOLM, 1992; MARTIN et al., 2008). Hypotheses which postulate that the earliest form of life consisted of primitive chemoautotrophism in reducing hydrothermal settings (DE DUVE, 1991; HUBER and WACHTERSHAUSER, 1997; MARTIN and RUSSELL, 2006) all invoke the existence of a geological supply of simple thiol molecules in the prebiotic environment as a precursor for the synthesis of thioester (R-CO-S-R'). The latter is the key functional group of the Acetyl-CoA enzyme central to the autotrophic metabolisms of primitive methanogens and acetogens (FUCHS, 1989). Conversion of $\mathrm{CO}$ and $\mathrm{CH}_{3} \mathrm{SH}$ to methyl thioacetate $\left(\mathrm{CH}_{3}-\mathrm{CO}-\mathrm{S}-\mathrm{CH}_{3}-\right.$ the simplest thioester $)$ has been demonstrated in the presence of $\mathrm{Fe}$ and $\mathrm{Ni}$ sulfide minerals and water (HUBER and WACHTERSHAUSER, 1997). The requisite supply of $\mathrm{CH}_{3} \mathrm{SH}$ to the prebiotic environment has traditionally been assumed to be abiotic reduction of $\mathrm{CO}_{2}$ (typically the dominant form of carbon in hydrothermal solutions) by $\mathrm{H}_{2}$ in the presence of reduced sulfur (HUBER and WACHTERSHAUSER, 1997; MARTIN and RUSSELL, 2006) - as suggested by thermodynamic considerations (SCHULTE and ROGERS, 2004) and experimental evidence (HEINEN and LAUWERS, 1996; HUBER and WACHTERSHAUSER, 1997). However, the abundance of $\mathrm{CH}_{3} \mathrm{SH}$ in modern vent fluids has hitherto not been characterized and its origin is therefore poorly constrained. Investigations of abiotic organic compounds in hydrothermal fluids have to date focused on the origin of linear hydrocarbons and oxygenated organic compounds, such as those found at Rainbow and Lost City (Holm and Charlou, 2001; ChARlou et al., 2002; MCCOLlOM and SEeWALD, 2007; ProsKUROWSKI et al., 2008; KONN et al., 2009). The fundamental assumption regarding the origin of $\mathrm{CH}_{3} \mathrm{SH}$ and therefore chemoautotrophic life therefore requires testing. 
In 2008 a survey of $\mathrm{CH}_{3} \mathrm{SH}$ abundance in vent fluids from several mid-ocean ridge environments was conducted along with accompanying temperature, dissolved $\mathrm{CO}_{2}, \mathrm{CO}, \mathrm{CH}_{4}, \mathrm{H}_{2}$, and $\mathrm{H}_{2} \mathrm{~S}$ measurements in order to elucidate geochemical processes that could produce $\mathrm{CH}_{3} \mathrm{SH}$ under hydrothermal conditions. Fluids were collected from three bare-rock hydrothermal systems hosted in basalt, including Lucky Strike (LANGMUIR et al., 1997; VON DAMM et al., 1998) and TAG (THOMPSON et al., 1985; TIVEY et al., 1995) on the Mid-Atlantic Ridge (MAR) and 950'N (HAYMON et al., 1993; ProskUROWSKI et al., 2008) on the East Pacific Rise. Two bare-rock systems hosted in peridotite were also sampled, including Rainbow (CHARLOU et al., 2002) and Lost City (Kelley et al., 2001; ProsKurowsKi et al., 2008) on the Mid-Atlantic Ridge. To assess the influence of hydrothermal alteration of sedimentary organic matter on $\mathrm{CH}_{3} \mathrm{SH}$ formation, additional fluid samples were taken at the sediment-covered Guaymas Basin hydrothermal system (WELHAN and LUPTON, 1987). 


\section{Methods}

Fluid samples were collected using isobaric gas-tight samplers (SEEWALD et al., 2002) during a July-August 2008 cruise to the Mid-Atlantic Ridge with ROV Jason II and an OctoberNovember 2008 cruise with DSV Alvin to the Guaymas Basin and EPR. In most cases, high temperature fluids were sampled, but in the case of the $9^{\circ} 50^{\prime} \mathrm{N}$ site, sets of paired high temperature and associated nearby low temperature vents were targeted for comparison. Maximum vent temperatures were measured in real-time during sampling. Dissolved $\mathrm{CH}_{3} \mathrm{SH}, \mathrm{H}_{2}$, $\mathrm{H}_{2} \mathrm{~S}$ and $\mathrm{CO}$ concentrations were determined at sea within hours of recovery. $\mathrm{CH}_{3} \mathrm{SH}$ was analyzed by purge and trap gas chromatography (GC) with flame ionization detection (FID). $\mathrm{CH}_{3} \mathrm{SH}$ was quantitatively sparged from acidified fluid aliquots with helium, cryo-focused at $78^{\circ} \mathrm{C}$ on $n$-octane-coated silica, then thermally desorbed at $145^{\circ} \mathrm{C}$ onto a Carbograph $1 \mathrm{SC}$ packed column. GC analysis was conducted isothermally at $40^{\circ} \mathrm{C}$. Due to potentially surface-reactive nature of gaseous $\mathrm{CH}_{3} \mathrm{SH}$ (SIMO, 1998; WARDENCKI, 1998), de-activated glass and PTFE-coated tubing were used wherever possible in the purge and trap method. Errors of reproducibility for measured $\mathrm{CH}_{3} \mathrm{SH}$ were variable (mean 2 s error $\pm 16 \%$, range $\pm 0.4 \%$ to $\pm 68 \%$ ) with the greatest errors associated with lowest concentrations. $\mathrm{CH}_{4}, \mathrm{H}_{2}$ and $\mathrm{CO}$ were analyzed by $\mathrm{GC}$ as per SEEWALD et al. (2006). $\mathrm{H}_{2} \mathrm{~S}$ was determined either gravimetrically onshore after precipitation as $\mathrm{Ag}_{2} \mathrm{~S}$ at sea or potentiometrically at sea by $\mathrm{Ag} / \mathrm{AgCl}$ electrode. $\mathrm{pH}\left(25^{\circ} \mathrm{C}\right)$ was also measured potentiometrically by $\mathrm{Ag} / \mathrm{AgCl}$ electrode. Dissolved inorganic carbon $\left(\Sigma \mathrm{CO}_{2}\right), \mathrm{C}_{2+}$ hydrocarbon and $\delta^{13} \mathrm{C}_{\mathrm{CH} 4}$ fluid aliquots were stored in evacuated glass serum vials (with butyl rubber stoppers) and were analyzed after acidification by injecting volumes of headspace gas directly onto a Porapak Q packed column with TCD and FID. $\Sigma \mathrm{CO}_{2}$ data were corrected for partitioning between headspace-fluid phases. Mg was determined by ion chromatography. Analytical uncertainties ( $2 \mathrm{~s}$ ) are $\pm 10 \%$ for measured $\mathrm{H}_{2} \mathrm{~S}, \mathrm{CO}, \mathrm{H}_{2}, \mathrm{C}_{2+}$ hydrocarbon concentrations and $\pm 5 \%$ 
for $\mathrm{Mg}, \Sigma \mathrm{CO}_{2}$, and $\mathrm{CH}_{4} \cdot \delta^{13} \mathrm{C}_{\mathrm{CH} 4}$ values were determined on selected samples by isotope ratio monitoring-gas chromatography mass spectrometry using a Finnegan DeltaPlus XL mass spectrometer interfaced to an Agilent 6890 gas chromatograph through a GCIII interface (combustion furnace held at $950^{\circ} \mathrm{C}$ ). The pooled standard deviation $(2 \mathrm{~s})$ of all $\delta^{13} \mathrm{C}_{\mathrm{CH} 4}$ values was $0.3 \%$.

Because hydrothermal fluids are conventionally assumed to be devoid of $\mathrm{Mg}$ due to water-rock reaction at elevated temperatures (BISCHOFF and DICKSON, 1975; MOTTL and Holland, 1978; SEYFRIED and BISCHOFF, 1981), endmember compositions are calculated by extrapolating measured concentrations of individual species in multiple fluid samples from a given orifice to zero $\mathrm{Mg}$ concentration using a linear least squares regression weighted to pass through ambient bottom seawater concentrations (VON DAMM et al., 1985). For fluids that have undergone extensive mixing, such as the low temperature fluids at $9^{\circ} 50^{\prime} \mathrm{N}$, endmember compositions may not reflect a composition existing in the hydrothermal system if the species in question is added or removed from solution during the mixing process. However, zero $\mathrm{Mg}$ endmembers are calculated here to elucidate such non-conservative behavior during mixing of low $\mathrm{Mg}$, high temperature fluids with seawater. 


\section{RESULTS}

Measured concentrations of $\mathrm{CH}_{3} \mathrm{SH}, \mathrm{H}_{2} \mathrm{~S}, \Sigma \mathrm{CO}_{2}, \mathrm{CO}, \mathrm{CH}_{4}$ and associated $\mathrm{Mg}$ concentrations are shown in Table 3.1 for all collected samples and corresponding endmember compositions and lowest measured $\mathrm{pH}\left(25^{\circ} \mathrm{C}\right)$ values are shown in Table 3.2. This survey of three hydrothermal settings (basaltic, ultramafic and sediment-covered) reveals several key features in the distribution of $\mathrm{CH}_{3} \mathrm{SH}$ (Table 3.2). The range of endmember concentrations was greatest in fluids from the Guaymas Basin hydrothermal site $\left(8.1 \mathrm{nmol} / \mathrm{L}\right.$ to $\left.17 \times 10^{3} \mathrm{nmol} / \mathrm{L}\right)$. Concentrations were lowest in fluids at Lost City $(1.4-1.9 \mathrm{nmol} / \mathrm{L})$. A key observation is that for many moderate to high temperature $\left(>150^{\circ} \mathrm{C}\right)$ vent fluids in hydrothermal systems devoid of sediment, endmember $\mathrm{CH}_{3} \mathrm{SH}$ concentrations are reasonably uniform despite large changes in aqueous $\mathrm{H}_{2}$ concentrations (Table 3.2). The range of endmember concentrations at Lucky Strike and TAG (5.6-23.4 nmol/L), as well as that of $>150^{\circ} \mathrm{C}$ fluids at $9^{\circ} 50^{\prime} \mathrm{N}(4.0-11 \mathrm{nmol} / \mathrm{L})$, overlaps that of the more $\mathrm{H}_{2}$-rich fluids at Rainbow $\left(7.4\right.$ to $\left.2.9 \times 10^{2} \mathrm{nmol} / \mathrm{L}\right)$. Within the Rainbow fluids, higher endmember concentrations of $\mathrm{CH}_{3} \mathrm{SH}\left(55-2.9 \times 10^{2} \mathrm{nmol} / \mathrm{L}\right)$ are associated with the lower temperature fluids Ecurie and Mussel Beach, while the high temperature $\left(350-367^{\circ} \mathrm{C}\right)$ fluids have a much narrower range $(7.4-12 \mathrm{nmol} / \mathrm{L})$. 


\section{DisCUSSION}

Carbon dioxide, which is predominantly derived from magmatic degassing, represents the dominant form of oxidized C in many hydrothermal fluids (VON DAMM, 1995; KELLEY et al., 2002). Because there are strong thermodynamic drives for $\mathrm{CO}_{2}$ reduction to organic compounds at subsurface conditions encountered by circulating hydrothermal fluids (SHOCK, 1990, 1992; SHOCK and SCHULTE, 1998), it is generally considered the main C substrate for abiotic organic synthesis and is the assumed substrate for $\mathrm{CH}_{3} \mathrm{SH}$ formation in models for the origin of chemoautotrophism (HUBER and WACHTERSHAUSER, 1997; MARTIN and RUSSELL, 2006; RUSSELL and HALL, 2006; MARTIN et al., 2008). Reduction of $\mathrm{CO}_{2}$ to $\mathrm{CH}_{3} \mathrm{SH}$ can be summarized by the following overall reaction:

$$
\mathrm{CO}_{2}+\mathrm{H}_{2} \mathrm{~S}+3 \mathrm{H}_{2} \leftrightarrow \mathrm{CH}_{3} \mathrm{SH}+2 \mathrm{H}_{2} \mathrm{O}
$$

The stoichiometry of reaction (1) indicates that at a given temperature and pressure, increases in dissolved $\mathrm{H}_{2}$ should result in disproportionately large increases in $\mathrm{CH}_{3} \mathrm{SH}$ at equilibrium. As shown in Figure 3.1, $\mathrm{CH}_{3} \mathrm{SH}$ stability also increases dramatically with decreasing temperature. To compare observed concentrations with reaction (1) predictions, the equilibrium concentration of $\mathrm{CH}_{3} \mathrm{SH}$ according to reaction (1) is calculated at the temperature and pressure of all vent fluids sampled using thermodynamic data at conditions (SCHULTE and ROGERS, 2004) and endmember $\Sigma \mathrm{CO}_{2}, \mathrm{H}_{2} \mathrm{~S}$ and $\mathrm{H}_{2}$ abundances as mass balance constraints. These calculations assume metastable equilibrium between $\Sigma \mathrm{CO}_{2}, \mathrm{H}_{2}$ and the reduced species $\mathrm{CO}, \mathrm{HCOOH}$ (and $\mathrm{HCOO}^{-}$), $\mathrm{CH}_{2} \mathrm{O}, \mathrm{CH}_{3} \mathrm{OH}$ in accordance with the experimental observations of SEEWALD et al. (2006) and those presented in CHAPTER 2, in addition to equilibrium between $\Sigma \mathrm{CO}_{2}, \mathrm{H}_{2}, \mathrm{H}_{2} \mathrm{~S}$ and $\mathrm{CH}_{3} \mathrm{SH}$. $\Sigma \mathrm{CO}_{2}$ speciation $\mathrm{H}_{2} \mathrm{~S}$ dissociation are also considered. Activity coefficients of unity were assumed for all aqueous species in the absence of constraints on non-ideal behavior (GARRELS and Christ, 1965; ANDERSON, 2005). $\mathrm{pH}\left(25^{\circ}\right)$ values were used for all calculations. Most in 
situ $\mathrm{pH}$ values for high temperature fluids are up to $1 \mathrm{pH}$ unit higher (GERMAN and VON DAMM, 2003). However, this has no effect on predicted $\mathrm{CH}_{3} \mathrm{SH}$ abundance for any of the fluids presented here. Equilibrium between $\Sigma \mathrm{CO}_{2}, \mathrm{H}_{2}$ and $\mathrm{CH}_{4}$ is suppressed based on the sluggish equilibration timescale of this reaction (see CHAPTER 2).

The most striking observation is that the abundance of $\mathrm{CH}_{3} \mathrm{SH}$ does not vary substantially between the systems sampled relative to the distribution predicted by reaction (1), (Figure 3.2(A)). When fluids with similarly high temperatures $\left(350-370^{\circ} \mathrm{C}\right)$ are compared at TAG and Rainbow, reaction (1) predicts a range of concentrations of $\sim 10^{7} \mathrm{~mol} / \mathrm{L}$ yet observed $\mathrm{CH}_{3} \mathrm{SH}$ concentrations vary by less than an order of magnitude. Furthermore, measured concentrations at TAG and Lucky Strike, where $\mathrm{H}_{2}$ concentrations are extremely low relative to Rainbow, are both far in excess of equilibrium values predicted for reaction (1) while the reverse is true in fluids with higher $\mathrm{H}_{2}$ concentrations (Rainbow and $9^{\circ} 50 \mathrm{~N}$ ) and measured concentrations are below predicted values (Figure 3.2(A)). It is difficult to assess the significance of measured concentrations at Lost City given the uncertainties involved in predicting $\mathrm{CH}_{3} \mathrm{SH}$ abundances for reaction (1) at the high $\mathrm{pH}$ of Lost City fluids (10.5-10.6 at $25^{\circ} \mathrm{C}$ and $\left.1 \mathrm{~atm}\right)$. Concentrations of $\Sigma \mathrm{CO}_{2}$ are exceedingly low and consequently associated with large uncertainties. Furthermore, thermodynamic data for deprotonated methanethiol $\left(\mathrm{CH}_{3} \mathrm{~S}^{-}\right)$which has a $p \mathrm{~K}_{\mathrm{a}}$ of 10.5 (at $25^{\circ} \mathrm{C}, 1$ atm) are lacking at conditions relevant to Lost City. Acidity constants for many organic acids gradually increase with increasing temperature (SHOCK, 1992), but below $100^{\circ} \mathrm{C}$ the $p \mathrm{~K}_{\mathrm{a}}$ of $\mathrm{CH}_{3} \mathrm{SH}$ may not increase to an extent to warrant neglecting dissociation effects. However, though predictions may not be possible, concentrations were lowest in the Lost City fluids of all sampled. While our predicted values refer to vent $T-P$ conditions at the seafloor, it is unlikely that the dichotomy in $\mathrm{CH}_{3} \mathrm{SH}$ abundance between $\mathrm{H}_{2}$-rich and $\mathrm{H}_{2}$-poor fluids reflects equilibrium elsewhere within these hydrothermal systems (i.e. during recharge or reaction zone $T$ - $P$ conditions). By calculating 
the reaction quotient for the mass action according to reaction (1), the temperature dependence of the equilibrium constant for reaction (1) can be used to calculate apparent temperatures of equilibration according to the reaction. Apparent temperatures of equilibration according to reaction (1) are $436-456^{\circ} \mathrm{C}$ at Rainbow, slightly greater than expected reaction zone temperatures (ALLEN and SEYFRIED, 2004), but a much lower temperature of equilibration $\left(222^{\circ} \mathrm{C}\right)$ is apparent at $\mathrm{TAG}$, where reaction zone conditions are in excess of $363^{\circ} \mathrm{C}$. Apparent temperatures of equilibration are also low at Lucky Strike $\left(222-242^{\circ} \mathrm{C}\right)$ relative to measured temperatures $(270-$ $\left.308^{\circ} \mathrm{C}\right)$. At $9^{\circ} 50^{\prime} \mathrm{N}$, measured temperatures for high temperature fluids $\left(221-363^{\circ} \mathrm{C}\right)$ overlap the range of apparent temperatures of equilibration $\left(236-361^{\circ} \mathrm{C}\right)$. These apparent temperatures are inconsistent with equilibrium according to reaction (1) occurring at reaction zone conditions in all these systems. Therefore, this strongly suggests that equilibrium according to reaction (1) is kinetically inhibited in the majority of hydrothermal fluids. This is consistent with the results of CHAPTER 2, which suggest that equilibrium between $\mathrm{CO}_{2}, \mathrm{H}_{2}$ and $\mathrm{H}_{2} \mathrm{~S}$ is kinetically inhibited in the absence of mineral catalysts. This may be a result of the complexities of multiple reduction steps and the inherent requirements of $\mathrm{CO}_{2}, \mathrm{H}_{2}$ and $\mathrm{H}_{2} \mathrm{~S}$ reaction. Alternatively, if equilibrium is indeed occurring at depth within the Rainbow system alone, it may be the result of mineral catalysis by Fe-Ni phases unique to ultramafic rock (KLEIN and BACH, 2009). It has been suggested that reduction of $\mathrm{CO}$ is much more favorable for $\mathrm{CH}_{3} \mathrm{SH}$ synthesis relative to $\mathrm{CO}_{2}$, but in all vent fluids from bare rock hydrothermal systems where $\mathrm{CO}$ abundance was determined, chemical affinities for $\mathrm{CO}$ equilibrium with $\mathrm{CO}_{2}$ and $\mathrm{H}_{2}$ are near zero $(0.9-5.8 \mathrm{~kJ} / \mathrm{mol})$. This is consistent with previous experimental observations of rapid $\mathrm{CO}_{2}-\mathrm{H}_{2}-\mathrm{CO}$ equilibrium under hydrothermal conditions (SEEWALD et al., 2006).

Sluggish kinetics for reaction (1) alone cannot explain the excess $\mathrm{CH}_{3} \mathrm{SH}$ relative to equilibrium at TAG and Lucky Strike, hence other sources of $\mathrm{CH}_{3} \mathrm{SH}$ must be examined. $\mathrm{CH}_{4}$ is 
the other dominant form of carbon in hydrothermal fluids and in many low $\mathrm{H}_{2}$ fluids there are net thermodynamic drives for $\mathrm{CH}_{4}$ oxidation to $\mathrm{CO}_{2}$ (MCCOLlOM and SEEwald, 2007). A possible consequence of this may be that partial oxidation of $\mathrm{CH}_{4}$ occurs by reaction with $\mathrm{H}_{2} \mathrm{~S}$ to form $\mathrm{CH}_{3} \mathrm{SH}$ :

$$
\mathrm{CH}_{4}+\mathrm{H}_{2} \mathrm{~S} \leftrightarrow \mathrm{CH}_{3} \mathrm{SH}+\mathrm{H}_{2}
$$

Though reaction (2) has not been demonstrated experimentally, formation of alkyl thiols by hydrocarbon sulfidation is thought to occur in petroleum deposits (KREIN, 1993; ZHANG et al., 2008). Predicted $\mathrm{CH}_{3} \mathrm{SH}$ concentrations can be calculated according to reaction (2) using measured $\mathrm{CH}_{4}, \mathrm{H}_{2} \mathrm{~S}$ and $\mathrm{H}_{2}$ concentrations and assuming activity coefficients of 1 as for reaction (1) predictions. Based on these calculations, $\mathrm{CH}_{3} \mathrm{SH}$ is in apparent equilibrium with $\mathrm{CH}_{4}$ in the high temperature Rainbow fluids and in many low $\mathrm{H}_{2}$ fluids (Lucky Strike and TAG) it is closer to equilibrium with $\mathrm{CH}_{4}$ than $\mathrm{CO}_{2}$ (Figure 3.2(B)). The temperature and redox dependency of reaction (2) is directly opposite to reaction (1) and would be favored under higher temperature, more oxidizing conditions (Figure 3.1).

$\mathrm{CH}_{3} \mathrm{SH}$ was most abundant $(1.5-1.7 \mu \mathrm{mol} / \mathrm{L})$ at Guaymas Basin (Table 3.1) where hydrothermal alteration of immature organic-rich sediments (composed primarily of hemipelagic diatomaceous ooze) contributes several classes of thermogenic organic compounds to vent fluids (Welhan and LUPTON, 1987; SIMONEIT et al., 1988). While it is possible that high CO concentrations in some Guaymas fluids (above that of equilibrium with $\mathrm{CO}_{2}$ ) could drive $\mathrm{CH}_{3} \mathrm{SH}$ production (SCHUlte and ROGERS, 2004), it is more likely that $\mathrm{CH}_{3} \mathrm{SH}$ is derived either from incipient alteration of sedimentary organic matter or decomposition of the resulting products. Vents with $\mu \mathrm{mol} / \mathrm{L}$ levels of $\mathrm{CH}_{3} \mathrm{SH}$ (Theme Park, Cathedral Hill and Sulfide Spires) are characterized by lower temperatures and than vents with lower (nmol/L) $\mathrm{CH}_{3} \mathrm{SH}$ (Rebecca's Roost and Toadstool). $\quad \mathrm{C}_{1} / \mathrm{C}_{2}+\mathrm{C}_{3} n$-alkane ratios (SEEWALD, unpubl. data) for the latter (124- 
132) are much higher than those of the former (55-60) and the association of high $\mathrm{CH}_{3} \mathrm{SH}$ concentrations with $\mathrm{C}_{2+}$ hydrocarbons between these two groups of fluids suggests that similar processes are controlling both hydrocarbon and $\mathrm{CH}_{3} \mathrm{SH}$ concentrations. Lower $\mathrm{C}_{1} / \mathrm{C}_{2}+\mathrm{C}_{3}$ ratios are indicative of lower thermal maturities, as dissolved $\mathrm{C}_{2+}$ hydrocarbons ultimately decompose to $\mathrm{CH}_{4}$ with increasing thermal stress (CRUSE and SEEWALD, 2006). Alkyl thiols in petroleum reservoirs are also typically associated with lower thermal maturities (KREIN, 1993) but may form by hydrocarbon reactions with $\mathrm{H}_{2} \mathrm{~S}$ during hydrous pyrolysis (ZHANG et al., 2008).

The compositions of several moderate to low temperature fluids from bare-rock systems suggest that thermogenic or biogenic sources of $\mathrm{CH}_{3} \mathrm{SH}$ to vent fluids are also possible. Two moderate temperature $\left(180-191^{\circ} \mathrm{C}\right)$ fluids at Rainbow (Ecurie and Mussel Beach) are substantially enriched in $\mathrm{CH}_{3} \mathrm{SH}$ relative to high temperature $\left(>350^{\circ} \mathrm{C}\right)$ fluids there (Table 3.1). The temperatures and compositions of the latter at Rainbow are relatively uniform, reflecting a common source fluid (CHARLOU et al., 2002). The moderate temperature fluids, however, have similar endmember $\Sigma \mathrm{CO}_{2}, \mathrm{H}_{2}$ and $\mathrm{H}_{2} \mathrm{~S}$ concentrations to the higher temperature fluids, which strongly suggest they formed by conductive cooling of the latter. Of the moderate temperature fluids, Ecurie vent has a lower $\delta^{13} \mathrm{C}_{\mathrm{CH} 4}$ value (-19.9\%) relative to the uniform high temperature fluids (-17.1 to $-17.9 \%$ ), indicating net addition of ${ }^{13} \mathrm{C}$-depleted $\mathrm{CH}_{4}$. This could reflect addition of small quantities of $\mathrm{CH}_{4}$ of a thermogenic origin (MCCOLLOM and SEEWALD, 2007), and possible sources include thermal decomposition of vent biomass material or dissolved organic carbon (DOC). The former has yet to be conclusively demonstrated in hydrothermal settings, but DOC depletions relative to seawater in some high temperature vent fluids suggest pyrolysis of the latter may occur (LANG et al., 2006). It is possible that thermogenic processes may be contributing $\mathrm{CH}_{3} \mathrm{SH}$ to high temperature fluids in bare rock systems, and the apparent equilibration of reaction (2) in some instances merely reflects approach from the direction of 
excess $\mathrm{CH}_{3} \mathrm{SH}$. Further work is needed to constrain the possible contributions from pyrolysis of biomass material.

At $9^{\circ} 50^{\prime} \mathrm{N}$, two sets of paired high temperature fluids and nearby diffuse flow fluids (Table 3.2) show clear $\mathrm{CH}_{3} \mathrm{SH}$ enrichments associated with $\mathrm{CH}_{4}$ enrichments in the latter relative to their parent fluids. Crab Spa vent $\left(23^{\circ} \mathrm{C}\right)$ was observed to be venting 5.7-6.1 nmol/L measured $\mathrm{CH}_{3} \mathrm{SH}$ concentrations over the course of 3 days. While biomass decomposition is possible, active microbial methane production and consumption has been inferred (PROSKUROWSKI et al., 2008 ) in diffuse fluids at $9^{\circ} 50^{\prime} \mathrm{N}$ and these enrichments could reflect microbial activity. $\mathrm{CH}_{3} \mathrm{SH}$ has been implicated as an intermediate in anaerobic methane oxidation (MORAN et al., 2008), evidence for which has been detected at Guaymas Basin (TESKE et al., 2002).

The results of this survey challenge the validity of the assumed formation pathway for $\mathrm{CH}_{3} \mathrm{SH}$ in seafloor hydrothermal solutions. Current models for the origin of chemoautotrophic life in ultramafic hydrothermal settings analogous to Lost City invoke formation of $\mathrm{CH}_{3} \mathrm{SH}$ by $\mathrm{CO}_{2}$ or $\mathrm{CO}$ reduction at temperatures in the vicinity of $100^{\circ} \mathrm{C}$ (MARTIN and RUSSELL, 2006). Given the apparent disequilibrium between $\mathrm{CO}_{2}, \mathrm{H}_{2}, \mathrm{H}_{2} \mathrm{~S}$ and $\mathrm{CH}_{3} \mathrm{SH}$ evident in most high temperature fluids $\left(>150^{\circ} \mathrm{C}\right)$ from bare-rock hydrothermal systems, and the possibility of $\mathrm{CH}_{3} \mathrm{SH}$ formation from $\mathrm{CH}_{4}$ (which is more energetically favorable under higher temperature, more oxidizing conditions), such a source is not supported by the data presented here. In addition, yields of thioester reported in the experiments of HUBER and WACHTERSHAUSER (1997) were extremely low - less than $10 \%$ of $\mathrm{CH}_{3} \mathrm{SH}$ was converted to methyl thioacetate on the timescale of the experiments. Given the low (nmol/L) concentrations of $\mathrm{CH}_{3} \mathrm{SH}$ present in vent fluids compared to these experiments $(\sim 100 \mu \mathrm{mol} / \mathrm{L})$, this suggests that thioester yields in natural hydrothermal fluids may be much lower than previously assumed. 


\section{Conclusions}

A survey of $\mathrm{CH}_{3} \mathrm{SH}$ abundance in seafloor hydrothermal fluids reveals that in bare rock hydrothermal settings the abundance of $\mathrm{CH}_{3} \mathrm{SH}$ does not vary substantially with redox conditions, as would be expected for a species purported to be derived from abiotic $\mathrm{CO}_{2}$ reduction. Enrichments in vent fluids from the sedimented Guaymas Basin site and low temperature fluids at $9^{\circ} 50^{\prime} \mathrm{N}$ East Pacific Rise suggest that thermogenic and biogenic sources to vent fluids are possible. Further speculation on the origin of $\mathrm{CH}_{3} \mathrm{SH}$ in vent fluids and the exact nature of microbial or thermogenic processes contributing to dissolved abundances is limited by a paucity of observations of these processes. However, our results do provide compelling evidence that $\mathrm{CO}_{2}$ reduction to $\mathrm{CH}_{3} \mathrm{SH}$ is kinetically inhibited under hydrothermal conditions despite favorable thermodynamic conditions in ultramafic systems. If $\mathrm{CH}_{3} \mathrm{SH}$ formation in present day vent fluids is governed either by thermogenic processes or by high temperature $\mathrm{CH}_{4}$ oxidation, this implies that the feasibility of sustained abiotic thioester synthesis from $\mathrm{CH}_{3} \mathrm{SH}$ in low temperature reducing hydrothermal settings may be more limited than previously assumed. The possibility that reworking or pyrolysis of preexisting organic matter, either biomass or seawater-derived DOC, could contribute organic compounds of prebiotic relevance to vent fluids requires much further investigation. 


\section{ACKNOWLEDGEMENTS}

I would like to thank N.J. Pester, M. Rough and W.E. Seyfried for providing $\mathrm{Mg}, \mathrm{H}_{2} \mathrm{~S}$ and $\mathrm{pH}$ data for the Mid-Atlantic Ridge sites. Thanks also to Peter Saccocia and Marcel van der Meer for assistance with $\mathrm{H}_{2}$ and $\mathrm{CO}$ analysis during the Mid-Atlantic Ridge expedition. Field sampling

was made possible by NSF grants MCB-0702677 (Seewald and Sievert), OCE-0549829 (Seewald). 
Table 3.1. Measured concentrations of dissolved species

\begin{tabular}{|c|c|c|c|c|c|c|c|c|c|}
\hline Site (depth), Vent & Sample & $\begin{array}{c}\mathrm{Mg} \\
(\mathrm{mmol} / \mathrm{kg})\end{array}$ & $\begin{array}{c}\mathrm{CH}_{3} \mathrm{SH} \\
(\mathrm{nmol} / \mathrm{L})\end{array}$ & $\begin{array}{c}\mathrm{CH}_{3} \mathrm{SH} \text { error } \\
2 \mathrm{~s}(\mathrm{n}) \\
\end{array}$ & $\begin{array}{c}\mathrm{H}_{2} \mathrm{~S} \\
(\mathrm{mmol} / \mathrm{L})\end{array}$ & $\begin{array}{c}\begin{array}{c}\mathrm{H}_{2} \\
(\mathrm{mmol} / \mathrm{L})\end{array} \\
\end{array}$ & $\begin{array}{c}\Sigma \mathrm{CO}_{2} \\
(\mathrm{mmol} / \mathrm{kg})\end{array}$ & $\begin{array}{c}\mathrm{CO} \\
(\mu \mathrm{mol} / \mathrm{L})\end{array}$ & $\begin{array}{c}\mathrm{CH}_{4} \\
(\mathrm{mmol} / \mathrm{L})\end{array}$ \\
\hline \multicolumn{10}{|l|}{ Rainbow (2300m) } \\
\hline \multirow{2}{*}{ PP27/Exo2 } & J2-353-IGT3 & 6.9 & 6.7 & nd & 2.73 & 10.7 & 19.6 & 4.5 & 1.66 \\
\hline & J2-353-CGT-RED & 7.0 & 6.5 & nd & 2.97 & 10.6 & 17.8 & 4.4 & 1.65 \\
\hline \multirow[t]{2}{*}{ Stylo1 } & J2-354-IGT5 & 4.2 & 7.6 & $0.8(4)$ & 1.89 & 15.0 & 23.4 & 6.6 & 1.87 \\
\hline & J2-354-CGT-BLUE & 3.9 & 6.1 & $0.9(3)$ & 2.33 & 14.8 & 22.3 & 6.5 & 1.84 \\
\hline \multirow[t]{2}{*}{ CMSt.P\&P } & J2-354-IGT3 & 3.5 & 7.2 & $1.0(3)$ & 1.85 & 14.8 & 20.6 & 6.9 & 1.85 \\
\hline & J2-354-CGT-YELLOW & 49.5 & 1.1 & $0.1(3)$ & 0.09 & 1.5 & na & 0.4 & 0.18 \\
\hline \multirow{2}{*}{ X11 } & J2-355-IGT4 & 4.0 & 15.0 & $2.4(3)$ & 1.75 & 15.4 & 19.7 & 6.3 & 1.92 \\
\hline & J2-355-CGT-RED & 9.1 & 5.7 & $0.5(3)$ & 1.69 & 13.6 & 17.4 & 5.9 & 1.72 \\
\hline \multirow[t]{2}{*}{ Ecurie } & J2-354-IGT4 & 33.8 & 93 & $6.2(4)$ & 0.61 & 4.8 & 11.2 & 2.7 & 0.88 \\
\hline & J2-354-IGT8 & 13.2 & 223 & $9.8(3)$ & 1.40 & 9.4 & 18.7 & 5.9 & 1.68 \\
\hline Mussel Beach & J2-355-IGT8 & 7.2 & 48 & $4.0(3)$ & 1.54 & 14.4 & 21.8 & 7.3 & 1.75 \\
\hline \multicolumn{10}{|l|}{ Lost City (750m) } \\
\hline \multirow[t]{3}{*}{ Beehive } & J2-361-CGT-BLUE & 6.5 & 1.6 & $0.6(3)$ & 0.21 & 9.1 & $\mathrm{n} / \mathrm{d}$ & $\mathrm{BD}$ & 0.93 \\
\hline & J2-361-CGT-WUXI & 2.3 & 2.5 & $1.5(4)$ & 0.47 & 10.1 & 0.19 & $\mathrm{BD}$ & 1.04 \\
\hline & J2-361-IGT5 & 1.4 & 1.4 & $0.9(4)$ & 0.07 & 10.1 & 0.32 & $\mathrm{BD}$ & 1.03 \\
\hline Marker 6 & J2-362-IGT4 & 1.2 & 1.3 & $0.4(3)$ & 0.22 & 10.26 & 0.15 & $\mathrm{BD}$ & 1.13 \\
\hline \multicolumn{10}{|l|}{ Lucky Strike (1700m) } \\
\hline Isabel & J2-357-IGT5 & 2.8 & 6.1 & $1.7(3)$ & 3.06 & 0.03 & 106 & $\mathrm{BD}$ & 0.83 \\
\hline US 4 & J2-357-IGT3 & 2.3 & 5.3 & $1.3(4)$ & 3.22 & 0.05 & 127 & $\mathrm{BD}$ & 0.66 \\
\hline \multirow[t]{2}{*}{ Crystal } & J2-358-IGT8 & 2.9 & 23.0 & $3.0(3)$ & 3.07 & 0.04 & 110 & $\mathrm{BD}$ & 0.76 \\
\hline & J2-358-CGT-RED & 31.2 & 7.5 & $0.9(4)$ & 1.51 & 0.02 & 48.9 & $\mathrm{BD}$ & 0.32 \\
\hline \multirow[t]{2}{*}{ Medea } & J2-359-IGT2 & 4.2 & 5.4 & $0.7(3)$ & 2.17 & 0.06 & 90.3 & $\mathrm{BD}$ & 0.82 \\
\hline & J2-359-CGT-YELLOW & 3.8 & 5.6 & $0.7(3)$ & 2.51 & 0.06 & 91.2 & $\mathrm{BD}$ & 0.83 \\
\hline TAG $(3600 \mathrm{~m})$ & & & & & & & & & \\
\hline \multirow{2}{*}{ Black Smoker Complex } & J2-363-IGT5 & 3.9 & 11.6 & $2.5(3)$ & 4.70 & 0.10 & 4.94 & $\mathrm{BD}$ & 0.13 \\
\hline & J2-363-CGT-RED & 5.9 & 10.2 & $0.5(2)$ & 4.54 & 0.09 & 4.47 & $\mathrm{BD}$ & 0.12 \\
\hline \multicolumn{10}{|l|}{$9^{\circ} 50^{\prime} \mathrm{N}(2500 \mathrm{~m})$} \\
\hline Tica & 4464-IGT1 & 4.1 & 3.6 & $0.6(3)$ & 8.22 & 0.37 & 92.5 & 0.81 & 0.091 \\
\hline \multirow[t]{2}{*}{ Crab Spab } & 4464-IGT4 & 50.3 & 6.1 & $0.1(3)$ & 0.17 & 0.003 & 7.26 & $\mathrm{BD}$ & 0.010 \\
\hline & 4464-IGT5 & 50.5 & 5.7 & $0.3(3)$ & 0.19 & 0.003 & 7.26 & $\mathrm{BD}$ & 0.012 \\
\hline \multirow{3}{*}{ L Vent (hi-T) } & 4466-IGT3 & 50.0 & 5.9 & nd & 0.29 & 0.006 & 7.47 & $\mathrm{BD}$ & 0.009 \\
\hline & 4467-IGT1 & 4.3 & 7.8 & $0.03(2)$ & 5.18 & 0.72 & 8.81 & 0.20 & 0.071 \\
\hline & 4467-IGT5 & 8.9 & 9.8 & $0.6(3)$ & 4.60 & 0.70 & 8.18 & 0.18 & 0.070 \\
\hline L Vent (lo-T) & 4467-IGT6 & 41.1 & 17.8 & $1.3(3)$ & 1.00 & 0.028 & 3.93 & $\mathrm{BD}$ & 0.037 \\
\hline L Vent, Marker 8 & 4468-IGT4 & 9.1 & 7.5 & $0.6(3)$ & 4.73 & 0.63 & 8.19 & $\mathrm{BD}$ & 0.066 \\
\hline \multirow[t]{2}{*}{ Bio9 (HOBO) } & 4469-IGT4 & 3.3 & 4.3 & $0.8(3)$ & 10.2 & 0.92 & 86.9 & 1.64 & 0.076 \\
\hline & 4469-IGT5 & 3.0 & 3.2 & $0.3(3)$ & 11.0 & 0.87 & 86.7 & nd & 0.075 \\
\hline \multirow[t]{2}{*}{ Trick or Treat } & 4469-IGT1 & 5.7 & 11.1 & $3.0(3)$ & 17.1 & 1.0 & 60.4 & nd & 0.058 \\
\hline & 4469-IGT3 & 2.5 & 10.0 & $0.8(3)$ & 18.3 & 1.2 & 66.1 & 1.88 & 0.066 \\
\hline \multicolumn{10}{|l|}{ Guaymas Basin $(2000 \mathrm{~m})$} \\
\hline \multirow[t]{2}{*}{ Theme Park } & 4458-IGT1 & 3.5 & $1.4 \mathrm{E}+04$ & 3.6E3 (3) & 6.38 & 0.50 & 43.9 & nd & 41.5 \\
\hline & 4458-IGT8 & 31.9 & $6.5 \mathrm{E}+03$ & $0.8 \mathrm{E} 3(3)$ & 2.82 & 0.23 & 21.1 & nd & 18.8 \\
\hline Cathedral Hill & 4459-IGT5 & 41.0 & $3.5 \mathrm{E}+03$ & $0.2 \mathrm{E} 3(3)$ & 1.85 & 0.12 & 9.8 & 6.27 & 10.3 \\
\hline Sulfide Spires & 4461-IGT5 & 12.9 & $1.3 \mathrm{E}+04$ & $1.9 \mathrm{E} 3(3)$ & 5.33 & 0.42 & 31.8 & 75.6 & 32.8 \\
\hline & 4461-IGT8 & 32.3 & $6.1 \mathrm{E}+03$ & $0.8 \mathrm{E} 3(3)$ & 2.88 & 0.24 & 21.0 & 25.7 & 19.3 \\
\hline Toadstool & 4462-IGT5 & 11.3 & 8.5 & nd & 6.10 & 2.10 & 41.8 & $\mathrm{BD}$ & 49.7 \\
\hline & 4462-IGT6 & 2.42 & 6.1 & nd & 7.89 & 2.63 & 47.6 & $\mathrm{BD}$ & 61.0 \\
\hline Rebecca's Roost & 4462-IGT1 & 3.12 & 14.1 & $1(2)$ & 7.49 & 3.06 & 45.8 & $\mathrm{BD}$ & 54.5 \\
\hline & 4462-IGT4 & 5.64 & 5.1 & $2(2)$ & 7.27 & 2.96 & 43.6 & $\mathrm{BD}$ & 53.6 \\
\hline
\end{tabular}

$\mathrm{Mg}$ and $\mathrm{H}_{2} \mathrm{~S}$ data from MAR sites provided by N.Pester. $\mathrm{CH}_{3} \mathrm{SH}$ error represents the $2 \mathrm{~s}$ analytical error associated with $n$ measurements. $2 \mathrm{~s}$ analytical uncertainties associated with $\mathrm{H}_{2} \mathrm{~S}, \Sigma \mathrm{CO}_{2}$ and $\mathrm{CH}_{4}$ are $\pm 5 \%$, and those for $\mathrm{CO}$ are $\pm 10 \%$. 
Table 3.2 Endmember concentrations (extrapolated to zero $\mathrm{Mg}$ ) and lowest measured $\mathrm{pH}$ values

\begin{tabular}{|c|c|c|c|c|c|c|c|}
\hline Site (depth), Vent & $\begin{array}{l}\mathbf{T}_{\max } \\
\left({ }^{\circ} \mathbf{C}\right)\end{array}$ & pH $\left(25^{\circ}\right)$ & $\begin{array}{c}\mathrm{H}_{2} \\
(\mathrm{mmol} / \mathrm{L})\end{array}$ & $\begin{array}{c}\mathrm{H}_{2} \mathrm{~S} \\
(\mathrm{mmol} / \mathrm{L})\end{array}$ & $\begin{array}{c}\Sigma \mathrm{CO}_{2} \\
(\mathrm{mmol} / \mathrm{kg})\end{array}$ & $\begin{array}{c}\mathrm{CO} \\
(\mathrm{mmol} / \mathrm{L})\end{array}$ & $\begin{array}{c}\mathrm{CH}_{4} \\
(\mathrm{mmol} / \mathrm{L})\end{array}$ \\
\hline \multicolumn{8}{|l|}{ Rainbow (2300m) } \\
\hline PP27/Exo2 & 350 & 3.4 & 12.3 & 3.3 & 21.3 & 5.1 & 1.9 \\
\hline Stylo1 & 367 & 3.3 & 16.1 & 2.3 & 24.6 & 7.1 & 2.0 \\
\hline CMSt.P\&P & 365 & 3.3 & 16.0 & 2.1 & 22.3 & 6.9 & 2.0 \\
\hline $\mathrm{X} 11$ & 364 & 3.1 & 16.5 & 2.0 & 20.9 & 7.0 & 2.1 \\
\hline Ecurie & 191 & 3.0 & 12.6 & 1.9 & 24.8 & 7.8 & 2.3 \\
\hline Mussel Beach & 180 & 3.0 & 16.7 & 1.8 & 25.0 & 8.5 & 2.0 \\
\hline \multicolumn{8}{|l|}{ Lost City (750m) } \\
\hline Beehive & 96 & 10.6 & 10.4 & 0.3 & 0.18 & BD & 1.1 \\
\hline Marker 6 & 96 & 10.5 & 10.4 & 0.2 & 0.11 & $\mathrm{BD}$ & 1.1 \\
\hline \multicolumn{8}{|l|}{ Lucky Strike (1700m) } \\
\hline Isabel & 292 & 3.8 & 0.028 & 3.2 & 111.7 & $\mathrm{BD}$ & 0.9 \\
\hline US 4 & 299 & 3.9 & 0.053 & 3.4 & 132.7 & $\mathrm{BD}$ & 0.7 \\
\hline Crystal & 308 & 3.6 & 0.041 & 3.3 & 116.7 & $\mathrm{BD}$ & 0.8 \\
\hline Medea & 270 & 3.7 & 0.063 & 2.5 & 98.0 & $\mathrm{BD}$ & 0.9 \\
\hline \multicolumn{8}{|l|}{ TAG $(3600 \mathrm{~m})$} \\
\hline Black Smoker Complex & 363 & 3.3 & 0.1 & 5.1 & 5.0 & $\mathrm{BD}$ & 0.2 \\
\hline \multicolumn{8}{|l|}{$9^{\circ} 50^{\prime} \mathrm{N}(2500 \mathrm{~m})$} \\
\hline Tica & 275 & 3.8 & 0.40 & 8.9 & 99.8 & 0.88 & 0.099 \\
\hline Crab Spa ${ }^{a}$ & 23 & 5.7 & 0.059 & 3.3 & 78.4 & $\mathrm{BD}$ & 0.15 \\
\hline L Vent (hi-T) & 246 & 3.8 & 0.81 & 5.6 & 9.4 & 0.22 & 0.080 \\
\hline$L \operatorname{Vent}(l o-T)^{b}$ & 78 & 5.8 & 0.12 & 4.2 & 9.5 & $\mathrm{BD}$ & 0.15 \\
\hline L Vent, Marker 8 & 221 & 4.2 & 0.75 & 5.7 & 9.4 & $\mathrm{n} / \mathrm{d}$ & 0.080 \\
\hline Bio9 (HOBO) & 363 & 3.5 & 0.95 & 11.3 & 92.0 & 1.8 & 0.081 \\
\hline Trick or Treat & 280 & 3.8 & 1.2 & 19.1 & 68.3 & 2.0 & 0.067 \\
\hline \multicolumn{8}{|l|}{ Guaymas Basin (2000m) } \\
\hline Theme Park & 249 & 5.7 & 0.54 & 6.8 & 47.2 & $\mathrm{n} / \mathrm{d}$ & 44.8 \\
\hline Cathedral Hill & 172 & 5.7 & 0.51 & 7.7 & 33.8 & 26 & 43.2 \\
\hline Sulfide Spires & 218 & 4.5 & 0.56 & 7.0 & 42.7 & 92 & 44.2 \\
\hline Toadstool & 299 & 6.1 & 2.7 & 8.0 & 50.8 & $\mathrm{n} / \mathrm{d}$ & 63.5 \\
\hline Rebecca's Roost & 278 & 6.1 & 3.3 & 8.0 & 48.4 & $\mathrm{n} / \mathrm{d}$ & 58.8 \\
\hline Seawater & 3 & 8 & 0 & 0 & 2.2 & 0 & 0 \\
\hline
\end{tabular}

${ }^{\mathrm{a}, \mathrm{b}}$ Low temperature 'Crab Spa' and 'L Vent (lo-T)' fluids are considered to have been derived from nearby 'Tica' and 'L Vent (hiT)/Marker 8' high temperature fluids, respectively. The end-member compositions of all vents were calculated by extrapolating measured compositions to zero Mg using linear least squares regression. 'Crab Spa' and 'L Vent (lo-T)' endmembers required large extrapolations and do not reflect represent an existing composition, but are useful in demonstrating the deviation from conservative dilution of their parent fluids. $\mathrm{pH}\left(25^{\circ} \mathrm{C}\right)$ values represent the lowest measured values of all samples for a given vent fluid. 


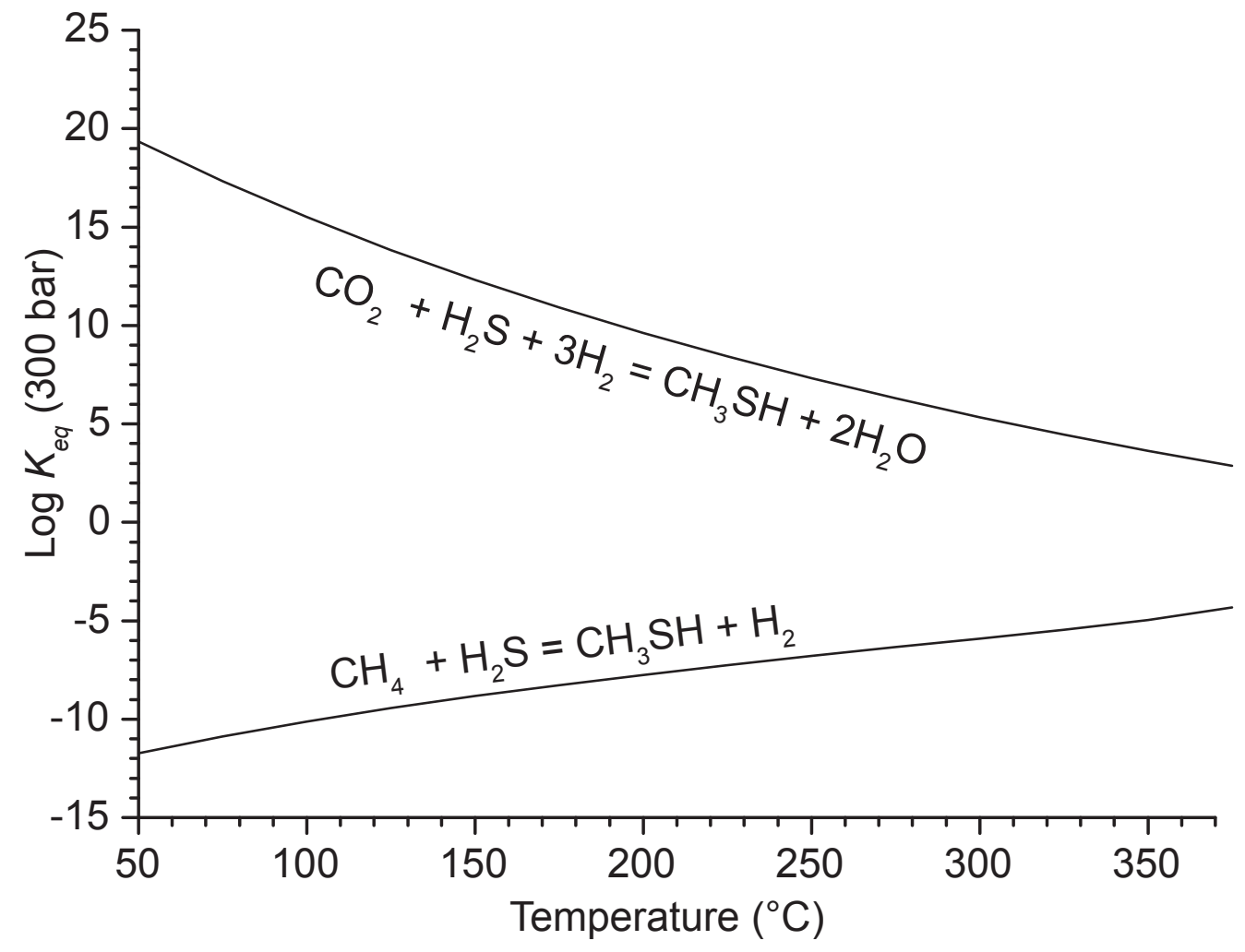

Figure 3.1.

Equilibrium constants ( $\mathrm{Log} K_{\text {eq }}$ ) for the formation of $\mathrm{CH}_{3} \mathrm{SH}$ from either $\mathrm{CO}_{2}$ (reduction) or $\mathrm{CH}_{4}$ (oxidation) as a function of temperature at 300 bar. Formation of $\mathrm{CH}_{3} \mathrm{SH}$ by $\mathrm{CO}_{2}$ reduction is favored under lower temperature, more reducing conditions, whereas formation from $\mathrm{CH}_{4}$ is favored under higher temperature, more oxidizing conditions. Thermodynamic data for the construction of this figure were obtained from the SUPCRT92 database (JOHNSON et al., 1992) with additional data from SHOCK and HELGESON (1990) and SCHULTE and ROGERS (2004). 


\section{Figure 3.2.}

Predicted concentration (open symbols) of $\mathrm{CH}_{3} \mathrm{SH}$ according to reaction (1), (A), and reaction (2), (B) as a function of measured $\mathrm{H}_{2}$ concentrations. Measured concentrations are shown as filled symbols. Activity coefficients of unity are assumed for all neutral species. Only moderate to high temperature vents $\left(>150^{\circ} \mathrm{C}\right)$ from bare rock hydrothermal systems are plotted for clarity. 


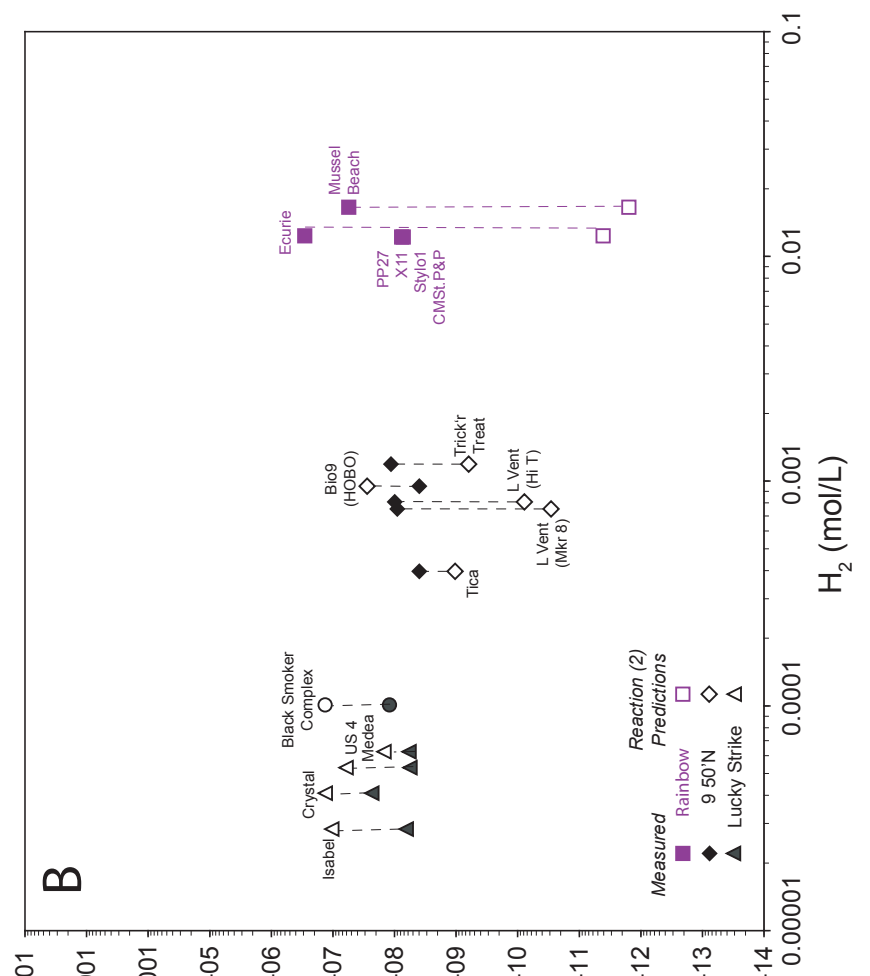

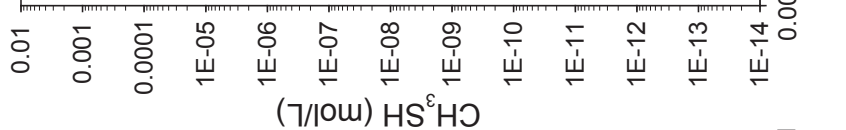

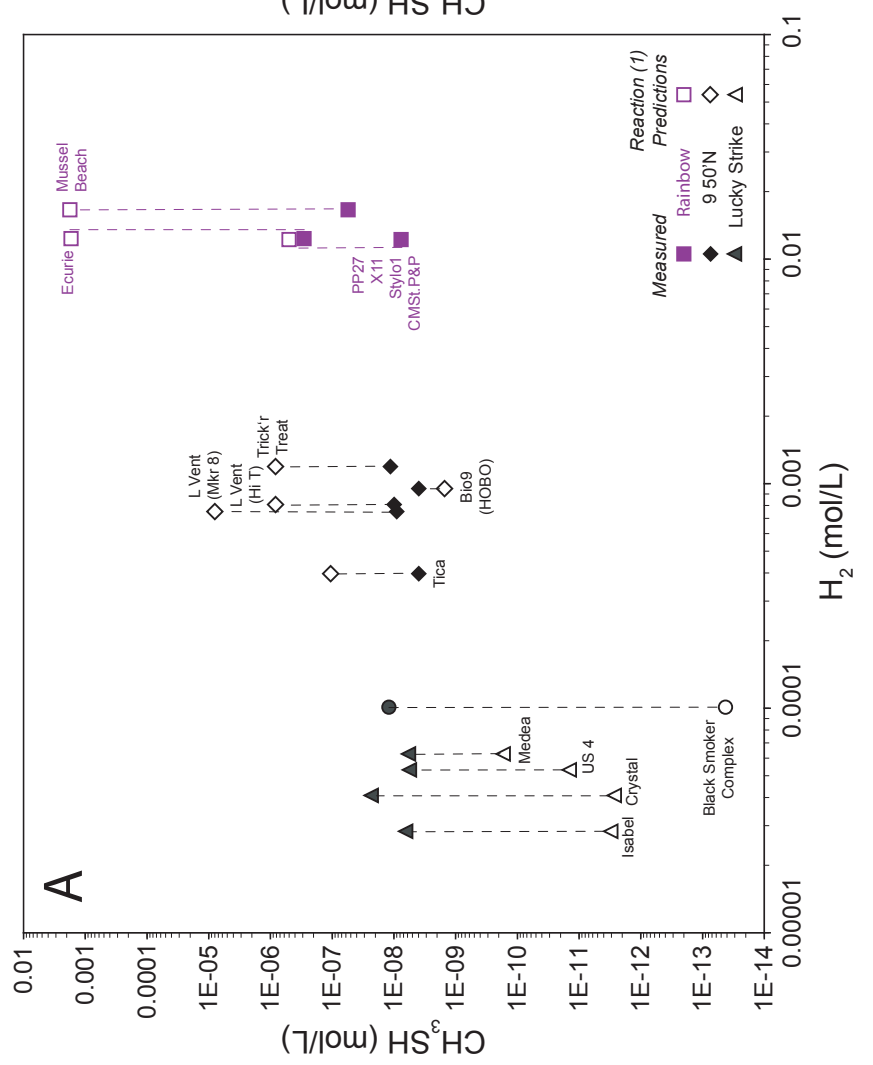

กั 


\section{REFERENCES}

Allen, D. E. and SEYFRIED, W. E. (2004) Serpentinization and heat generation: Constraints from Lost City and Rainbow hydrothermal systems. Geochimica Et Cosmochimica Acta 68(6), $1347-1354$

Anderson, G. (2005) Thermodynamics of Natural Systems. Cambridge University Press.

Baross, J. A. and Hoffman, S. E. (1985) Submarine Hydrothermal Vents And Associated Gradient Environments As Sites For The Origin And Evolution Of Life. Origins Of Life And Evolution Of The Biosphere 15(4), 327-345.

BISCHOFF, J. L. and DiCKSON, F. W. (1975) Seawater-basalt interaction at $200^{\circ} \mathrm{C}$ and 500 bars: Implications for origin of sea-floor heavy-metal deposits and regulation of seawater chemistry. Earth and Planetary Science Letters 25, 385-397.

Charlou, J. L., Donval, J. P., Fouquet, Y., Jean-Baptiste, P., and Holm, N. (2002) Geochemistry of high $\mathrm{H}_{2}$ and $\mathrm{CH}_{4}$ vent fluids issuing from ultramafic rocks at the Rainbow hydrothermal field (36²14'N, MAR). Chemical Geology 191(4), 345-359.

Corliss, J. B., BAross, J. A., and Hoffman, S. E. (1981) An hypothesis concerning the relationship between submarine hot springs and the origin of life on Earth. Oceanologica Acta 4(Supplement), 59-69.

CRuse, A. M. and SEEWALD, J. S. (2006) Geochemistry of low-molecular weight hydrocarbons in hydrothermal fluids from Middle Valley, northern Juan de Fuca Ridge. Geochimica Et Cosmochimica Acta 70(8), 2073-2092.

DE DuvE, C. (1991) Blueprint for a Cell: The Nature and Origin of Life. N. Patterson.

FUCHS, G. (1989) Alternative pathways of autotrophic $\mathrm{CO}_{2}$ fixation. In: Autotrophic bacteria, (Ed: H. G. Schlegel and B. Bowien), Science Tech Publishers. pp. 365-382.

GARrels, R. M. and Christ, C. L. (1965) Solutions, Minerals, and Equilibria. Harper \& Row. 
German, C. and Von Damm, K. L. (2003) Hydrothermal Processes. In: The Treatise on Geochemistry, (Ed: K. K. Turekian and H. D. Holland), 6.07, Elsevier. pp. 181-222.

Haymon, R. M., Fornari, D. J., Vondamm, K. L., Lilley, M. D., Perfit, M. R., Edmond, J. M., Shanks, W. C., Lutz, R. A., Grebmeier, J. M., CARbotte, S. et al. (1993) Volcanic-Eruption Of The Mid-ocean Ridge Along The East Pacific Rise Crest At $9^{\circ} 45$ 52 'N - Direct Submersible Observations Of Sea-Floor Phenomena Associated With An Eruption Event In April, 1991. Earth And Planetary Science Letters 119(1-2), 85-101.

HEINEN, W. and LAUWERS, A. M. (1996) Organic sulfur compounds resulting from the interaction of iron sulfide, hydrogen sulfide and carbon dioxide in an anaerobic aqueous environment. Origins Of Life And Evolution Of The Biosphere 26(2), 131-150.

HoLm, N. G. (1992) Marine Hydrothermal Systems and the Origin of Life: Report of SCOR Working Group 91. Reprinted from: Origins of Life and Evolution of the Biosphere, Vol. 22 (1-4), 1992. Springer.

HOLM, N. G. and CHARLOU, J. L. (2001) Initial indications of abiotic formation of hydrocarbons in the Rainbow ultramafic hydrothermal system, Mid-Atlantic Ridge. Earth And Planetary Science Letters 191(1-2), 1-8.

Huber, C. and WACHTERShauser, G. (1997) Activated acetic acid by carbon fixation on (Fe,Ni)S under primordial conditions. Science 276(5310), 245-247.

Johnson, J. W., OELKERs, E. H., and HELGESON, H. C. (1992) SUPCRT92 - A software package for calculating the standard molal thermodynamic properties of minerals, gases, aqueous species, and reactions from 1 to 5000 bar and 0 to $1000^{\circ} \mathrm{C}$. Computers \& Geosciences 18(7), 899-947. 
Kelley, D. S., BARoss, J. A., and Delaney, J. R. (2002) Volcanoes, fluids, and life at midocean ridge spreading centers. Annual Review Of Earth And Planetary Sciences 30, $385-$ 491.

Kelley, D. S., Karson, J. A., Blackman, D. K., Fruh-Green, G. L., Butterfield, D. A., Lilley, M. D., Olson, E. J., SchrenK, M. O., Roe, K. K., Lebon, G. T. et al. (2001) An off-axis hydrothermal vent field near the Mid-Atlantic Ridge at $30^{\circ} \mathrm{N}$. Nature $412(6843)$, $145-149$.

KLEIN, F. and BACH, W. G. (2009) Fe-Ni-Co-O-S Phase Relations in Peridotite-Seawater Interactions. Journal Of Petrology 50(1), 37-59.

Konn, C., Charlou, J. L., Donval, J. P., Holm, N. G., Dehairs, F., and Bouillon, S. (2009) Hydrocarbons and oxidized organic compounds in hydrothermal fluids from Rainbow and Lost City ultramafic-hosted vents. Chemical Geology 258(3-4), 299.

KREIN, E. B. (1993) Organic sulfur in the geosphere: analysis, structures and chemical processes. In: Supplement S: The chemistry of Sulphur-containing functional groups, (Ed: S. Patai and Z. Rappoport), Wiley. pp. 975-1032.

Lang, S. Q., Butterfield, D. A., Lilley, M. D., Johnson, H. P., and Hedges, J. I. (2006) Dissolved organic carbon in ridge-axis and ridge-flank hydrothermal systems. Geochimica Et Cosmochimica Acta 70(15), 3830-3842.

LANGmuir, C., Humphris, S., Fornari, D., VAnDover, C., VonDamm, K., Tivey, M. K., Colodner, D., Charlou, J. L., Desonie, D., Wilson, C. et al. (1997) Hydrothermal vents near a mantle hot spot: The Lucky Strike vent field at 37 degrees N on the MidAtlantic Ridge. Earth And Planetary Science Letters 148(1-2), 69-91.

MARTIN, W. and RuSSELL, M. J. (2006) Review: On the origin of biochemistry at an alkaline hydrothermal vent. Philosophical Transactions Of The Royal Society Of London Series 
B: Biological Sciences, Page FirstCite, DOI 10.1098/rstb.2006.1881, URL:

http://dx.doi.org/10.1098/rstb.2006.1881.

Martin, W., BARoss, J., Kelley, D., and Russell, M. J. (2008) Hydrothermal vents and the origin of life. Nature Reviews Microbiology 6(11), 805-814.

McCollom, T. M. and SEeWALd, J. S. (2007) Abiotic synthesis of organic compounds in deepsea hydrothermal environments. Chemical Reviews 107, 382-401.

Moran, J. J., Beal, E. J., Vrentas, J. M., Orphan, V. J., Freeman, K. H., and House, C. H. (2008) Methyl sulfides as intermediates in the anaerobic oxidation of methane. Environmental Microbiology 10(1), 162-173.

MotTL, M. J. and Holland, H. D. (1978) Chemical exchange during hydrothermal alteration of basalt by seawater-I. Experimental results for major and minor components of seawater. Geochimica et Cosmochimica Acta 42(8), 1103-1115.

Proskurowski, G., Lilley, M. D., and Olson, E. J. (2008) Stable isotopic evidence in support of active microbial methane cycling in low-temperature diffuse flow vents at $9^{\circ} 50 ' \mathrm{~N}$ East Pacific Rise. Geochimica et Cosmochimica Acta 72(8), 2005-2023.

Proskurowski, G., Lilley, M. D., Seewald, J. S., Fruh-Green, G. L., Olson, E. J., LuPton, J. E., SYlVA, S. P., and Kelley, D. S. (2008) Abiogenic hydrocarbon production at Lost City hydrothermal field. Science 319(5863), 604-607.

Russell, M. J. and HALl, A. J. (2006) The onset and early evolution of life. In: Evolution of Early Earth's Atmosphere, Hydrosphere, and Biosphere - Constraints from Ore Deposits: Geological Society of America Memoir 198, (Ed: S. E. Kesler and H. Ohmoto), Geological Society of America. pp. 1-32. 
SCHUlte, M. D. and Rogers, K. L. (2004) Thiols in hydrothermal solution: standard partial molal properties and their role in the organic geochemistry of hydrothermal environments. Geochimica Et Cosmochimica Acta 68(5), 1087-1097.

SEewald, J. S., Zolotov, M. Y., and McCollom, T. (2006) Experimental investigation of single carbon compounds under hydrothermal conditions. Geochimica Et Cosmochimica Acta 70(2), 446-460.

Seewald, J. S., Doherty, K. W., Hammar, T. R., and Liberatore, S. P. (2002) A new gastight isobaric sampler for hydrothermal fluids. Deep-Sea Research Part I-Oceanographic Research Papers 49(1), 189-196.

SEYFRIED, W. E. and BISCHOFF, J. L. (1981) Experimental seawater-basalt interaction at $300^{\circ} \mathrm{C}$, 500 bars, chemical exchange, secondary mineral formation and implications for the transport of heavy-metals. Geochimica et Cosmochimica Acta 45(2), 135-147.

SHOCK, E. L. (1990) Geochemical constraints on the origin of organic compounds in hydrothermal systems. Origins Of Life And Evolution Of The Biosphere 20(3-4), 331-367.

SHOCK, E. L. (1992) Chemical Environments Of Submarine Hydrothermal Systems. Origins Of Life And Evolution Of The Biosphere 22(1-4), 67-107.

SHock, E. L. and Helgeson, H. C. (1990) Calculation of the thermodynamic and transport properties of aqueous species at high pressures and temperatures: Standard partial molal properties of organic species. Geochimica et Cosmochimica Acta 54(4), 915-945.

SHOCK, E. L. and SCHULTE, M. D. (1998) Organic synthesis during fluid mixing in hydrothermal systems. Journal Of Geophysical Research-Planets 103(E12), 28513-28527.

SimO, R. (1998) Trace chromatographic analysis of dimethyl sulfoxide and related methylated sulfur compounds in natural waters. Journal Of Chromatography A 807(2), 151-164. 
Simoneit, B. R. T., KAwKA, O. E., and Brault, M. (1988) Origin Of Gases And Condensates In The Guaymas Basin Hydrothermal System (Gulf Of California). Chemical Geology 71(13), 169-182.

Teske, A., Hinrichs, K. U., Edgcomb, V., Gomez, A. D., Kysela, D., Sylva, S. P., Sogin, M. L., and JANNASCH, H. W. (2002) Microbial diversity of hydrothermal sediments in the Guaymas Basin: Evidence for anaerobic methanotrophic communities. Applied And Environmental Microbiology 68(4), 1994-2007.

Thompson, G., MotTL, M. J., and RonA, P. A. (1985) Morphology, Mineralogy And Chemistry Of Hydrothermal Deposits From The TAG Area, $26^{\circ} \mathrm{N}$ Mid-Atlantic Ridge. Chemical Geology 49(1-3), 243-257.

Tivey, M. K., Humphris, S. E., Thompson, G., Hannington, M. D., and RonA, P. A. (1995) Deducing patterns of fluid flow and mixing within the TAG active hydrothermal mound using mineralogical and geochemical data. Journal Of Geophysical Research-Solid Earth 100(B7), 12527-12555.

VON DAMM, K. L. (1995) Controls on the chemistry and temporal variability of seafloor hydrothermal systems. In: Seafloor Hydrothermal Systems: Physical, Chemical, Biological, and Geological Interactions, (Ed: S. E. Humphris, R. A. Zierenberg, L. S. Mullineaux, and R. E. Thomson), AGU Monograph, 91, American Geophysical Union. pp. $222-247$.

Von DAMM, K. L., EDMOND, J. M., GRANT, B., and MEASURES, C. I. (1985) Chemistry of submarine hydrothermal solutions at $21^{\circ} \mathrm{N}$, East Pacific Rise. Geochimica et Cosmochimica Acta 49(11), 2197-2220. 
Von Damm, K. L., Bray, A. M., Buttermore, L. G., and Oosting, S. E. (1998) The geochemical controls on vent fluids from the Lucky Strike vent field, Mid-Atlantic Ridge. Earth and Planetary Science Letters 160(3-4), 521-536.

WARDENCKI, W. (1998) Problems with the determination of environmental sulphur compounds by gas chromatography. Journal Of Chromatography A 793(1), 1-19.

WelHAN, J. A. and LuPTON, J. (1987) Light Hydrocarbon Gases In Guaymas Basin Hydrothermal Fluids: Thermogenic Versus Abiogenic Origin. AAPG Bulletin 71(2), 215223.

Zhang, T. W., Amrani, A., Ellis, G. S., Ma, Q. S., and TANG, Y. C. (2008) Experimental investigation on thermochemical sulfate reduction by $\mathrm{H} 2 \mathrm{~S}$ initiation. Geochimica Et Cosmochimica Acta 72(14), 3518-3530. 


\title{
CHAPTER 4
}

\section{Rapid hydrogen isotope $\left({ }^{2} \mathrm{H} /{ }^{1} \mathrm{H}\right)$ exchange between aqueous $n$-alkanes and water under hydrothermal conditions: implications for the isotopic composition of abiogenic and thermogenic hydrocarbons}

\begin{abstract}
Experiments were conducted to investigate ${ }^{2} \mathrm{H} /{ }^{1} \mathrm{H}$ exchange between aqueous hydrocarbons and water under hydrothermal conditions. $\mathrm{C}_{1}-\mathrm{C}_{5} n$-alkanes were heated in aqueous solutions of varying initial ${ }^{2} \mathrm{H} /{ }^{1} \mathrm{H}$ ratio in the presence of a pyrite-pyrrhotite-magnetite mineral redox buffer at $323^{\circ} \mathrm{C}$ and 350 bar using a Au-Ti flexible cell hydrothermal apparatus. Extensive and completely reversible incorporation of water-derived $\mathrm{H}$ into $\mathrm{C}_{3}-\mathrm{C}_{5} n$-alkanes was observed on timescales of months. In contrast, comparatively minor exchange was observed for $\mathrm{CH}_{4}$ and ethane. Isotopic exchange is facilitated by rapid reversible equilibration of $n$-alkanes and their corresponding alkenes and water-derived $\mathrm{H}_{2}$. Rates of $\delta^{2} \mathrm{H}$ variation in $\mathrm{C}_{3+} n$-alkanes decreased with time, consistent with an apparent approach to steady-state isotopic compositions regulated by alkanewater isotopic equilibrium. Substantially slower exchange rates were observed for ethane relative to $\mathrm{C}_{3}-\mathrm{C}_{5} n$-alkanes, suggesting that alkane/alkene abundances and isomerization reactions may dramatically enhance rates of $\mathrm{H}$ incorporation in longer chain hydrocarbons. Thus, in reducing aqueous environments, reaction mechanisms exist that allow rapid ${ }^{2} \mathrm{H} /{ }^{1} \mathrm{H}$ exchange of alkyl-H with water at elevated temperatures and pressures on relatively short geological timescales. The proximity of some abiogenic and thermogenic alkane $\delta^{2} \mathrm{H}$ values to values predicted for
\end{abstract}


equilibrium fractionation with ambient water suggests that this process may occur in natural systems. 


\section{INTRODUCTION}

Compound-specific stable hydrogen isotope $\left({ }^{1} \mathrm{H}\right.$ and $\left.{ }^{2} \mathrm{H}\right)$ measurements of carbon-bound hydrogen (TOBIAS and BRENNA, 1997; BURGOYNE and HAYES, 1998; HILKERT et al., 1999; SESSIONS, 2006) have recently become widespread in organic geochemistry. The hydrogen isotope composition of $n$-alkanes have been utilized to elucidate such diverse processes as abiogenic hydrocarbon formation (SHERWOOD LOLLAR et al., 2002; FU et al., 2007;

PROSKUROWSKI et al., 2008), formation and biodegradation of petroleum constituents (SCHOELL, 1983; WHITICAR et al., 1985; TANG et al., 2005; SCHIMMELMANN et al., 2006; BOREHAM et al., 2008) and paleoenvironmental changes (SCHEFUSS et al., 2005; SACHSE et al., 2006; EGLINTON and EGLINTON, 2008). However, use of $\delta^{2} \mathrm{H}$ measurements to infer primary isotopic influences (i.e. kinetic or equilibrium isotope effects associated with hydrocarbon formation) implicitly assumes the resistance of organic hydrogen to secondary exchange processes over pertinent geologic timeframes. There is growing evidence to suggest that exchange or incorporation of water-derived $\mathrm{H}$ into organic molecules can obscure primary isotopic signatures but there are still significant gaps in our understanding of this process (SESSIONS et al., 2004; SCHIMMELMANN et al., 2006).

Recently, studies of ${ }^{2} \mathrm{H} /{ }^{1} \mathrm{H}$ ratios have been expanded to the low molecular weight (LMW) $n$-alkanes $\left(\mathrm{C}_{1}\right.$ to $\left.\mathrm{C}_{5}\right)$, which represent an important class of compounds in a variety of high temperature fluids. The formation of abiogenic LMW n-alkanes associated with serpentinization of ultramafic igneous crust is currently the subject of extensive interest (BERNDT et al., 1996; MCCOLlOM and SEEWALD, 2001, 2007; FU et al., 2007; PROSKUROWSKI et al., 2008) and $\delta^{2} \mathrm{H}$ measurements been used to infer mechanistic information regarding abiogenesis (SHERWOOD LOLlaR et al., 2002). Moreover, $\mathrm{C}_{1}$ to $\mathrm{C}_{5} n$-alkanes are abundantly present in oil and natural gas formed by thermal maturation of sedimentary organic matter (TISSOT and WELTE, 
1984; HUNT, 1996) and there is interest in developing their ${ }^{2} \mathrm{H} /{ }^{1} \mathrm{H}$ signatures as maturation and correlation parameters for petroleum characterization (TANG et al., 2007). Understanding the provenance of these hydrocarbons is crucial both for the management of natural gas resources and elucidating the potential for abiogenic organic synthesis in hydrothermal settings. The usefulness of $\delta^{2} \mathrm{H}$ values in this respect is problematic, however, given the uncertainty in our understanding of controls on hydrocarbon ${ }^{2} \mathrm{H} /{ }^{1} \mathrm{H}$ ratios in water-rich environments.

A significant source of uncertainty stems from the fact that the susceptibility of hydrocarbons to isotopic exchange with ambient water at elevated temperatures is unclear. In addition to its obvious ubiquity in hydrothermal systems, water may be a reactive source of $\mathrm{H}$ not just during the generation of petroleum hydrocarbons but also during subsequent migration and accumulation processes (LEWAN, 1997; SEEWALD, 2003; SCHIMMELMANN et al., 2006). While aliphatic $\mathrm{H}$ is typically considered to be the most isotopically conservative moiety under low temperature conditions (SCHIMMELMANN et al., 2006), aqueous reaction paths at elevated temperatures could facilitate reversible exchange with water-derived H. Experiments conducted under hydrothermal conditions have shown that $n$-alkanes (below $\mathrm{C}_{7}$ in length) and their corresponding $n$-alkenes rapidly attain reversible states of redox-dependant metastable equilibrium under redox-buffered conditions according to the following reaction (SEEWALD, 1994, 2001, 2003):

$$
\mathrm{C}_{\mathrm{n}} \mathrm{H}_{2 \mathrm{n}+2(\mathrm{aq})}=\mathrm{C}_{\mathrm{n}} \mathrm{H}_{2 \mathrm{n}(\mathrm{aq})}+\mathrm{H}_{2(\mathrm{aq})}
$$

Under progressively oxidizing conditions, further stepwise oxidation can occur via metastable ketone and alcohol intermediaries, leading to chain shortening and overall conversion of $n$ alkanes to $\mathrm{CO}_{2}$ and $\mathrm{CH}_{4}$. However, under reducing conditions the initial alkane-alkene reaction allows $n$-alkanes to persist in metastable reversible equilibrium with aqueous $\mathrm{H}_{2}$, depending on redox conditions. Because the latter is ultimately derived from water and these reactions are 
reversible, in theory reversible ${ }^{2} \mathrm{H} /{ }^{1} \mathrm{H}$ exchange may occur. This has not been verified and the timescales on which exchange could occur in natural systems are poorly constrained.

This chapter presents an experimental study of the potential for reversible ${ }^{2} \mathrm{H} /{ }^{1} \mathrm{H}$ exchange between dissolved $\mathrm{C}_{1}$ to $\mathrm{C}_{5} n$-alkanes and water at hydrothermal conditions, and the timescales on which such exchange might occur. As such it increases our understanding of possible controls on isotopic variability in LMW hydrocarbons, which is essential for proper interpretation of stable hydrogen isotope compositions of alkane $\mathrm{H}$ in geologic fluids. 


\section{Materials ANd Methods}

\subsection{Experimental Approach and Setup}

All experiments in this study were conducted by heating dissolved mixtures of $\mathrm{C}_{1}$ to $\mathrm{C}_{5} n$ alkanes in aqueous solutions of varying ${ }^{2} \mathrm{H} /{ }^{1} \mathrm{H}$ ratios within a flexible-cell hydrothermal apparatus of the type described by SEYFRIED (1987). The apparatus consists of a gold reaction cell equipped with titanium fittings and a capillary exit tube with sampling valve. The reaction cell is contained within a stainless steel pressure vessel (using de-ionized water as pressurizing fluid) and furnace. This apparatus has been used in numerous investigations of aqueous LMW organic compounds under hydrothermal conditions (MCCOLLOM and SEEWALD, 2001, 2003a,b; SEEWALD, 2001; SEEWALD et al., 2006; FU et al., 2007). A key feature is that it allows experiment to be conducted at constant pressure, thereby confining reactions to the aqueous phase. In addition, the capillary exit tube allows both removal of fluid aliquots for analysis of solution composition as a function of time and modification of reaction cell contents by injection of solutions without perturbing the temperature or pressure of the experiment. Rapid cooling of removed aliquots to room temperature also minimizes retrograde reactions that can occur during prolonged quenching. Both $\mathrm{Au}$ and $\mathrm{TiO}_{2}$ are also the least catalytic surfaces for carbon-carbon bond cleavage that can fulfill the requirements of the apparatus (PALMER and DRUMMOND, 1986; Bell et al., 1994; MCCOLlOM and SEewald, 2003a,b). Prior to use, the titanium fittings in contact with the reaction cell contents were previously heated in air for $24 \mathrm{~h}$ at $400^{\circ} \mathrm{C}$ to form an inert $\mathrm{TiO}_{2}$ surface layer.

Laboratory experiments have demonstrated that the stability of aqueous LMW $n$-alkanes is highly sensitive to the redox state of the fluid (SEEWALD, 1994, 2001). Hence, to demonstrate that variations in $n$-alkane ${ }^{2} \mathrm{H} /{ }^{1} \mathrm{H}$ ratios can be attributed to reversible ${ }^{2} \mathrm{H} /{ }^{1} \mathrm{H}$ exchange with water, rather than kinetic isotope effects associated with degradation/side reactions, it is crucial that the 
latter be simultaneously limited. SEEWALD (2001) demonstrated that overall rates of $n$-heptane degradation by stepwise aqueous oxidation varied dramatically depending on the mineral redox buffer employed. Of the three buffers used (pyrite-pyrrhotite-magnetite (PPM), hematitemagnetite-pyrite (HMP) and hematite-magnetite (HM)), $n$-alkane degradation was slowest with the more reducing PPM mineral assemblage (SEEWALD, 2001), hence, this buffer was chosen for all experiments (Figure 4.1). The PPM assemblage buffers both $\mathrm{H}_{2(\mathrm{aq})}$ and $\mathrm{H}_{2} \mathrm{~S}_{(\mathrm{aq})}$ activities ( $a_{\mathrm{H} 2(\mathrm{aq})}$ and $a_{\mathrm{H} 2 \mathrm{~S}(\mathrm{aq})}$, respectively) via the following chemical reactions:

$$
\begin{aligned}
& 1.5 \mathrm{FeS}_{(\mathrm{s})}+\mathrm{H}_{2} \mathrm{O}_{(\mathrm{l})}=0.75 \mathrm{FeS}_{2(\mathrm{~s})}+0.25 \mathrm{Fe}_{3} \mathrm{O}_{4(\mathrm{~s})}+\mathrm{H}_{2(\mathrm{aq})} \\
& \mathrm{FeS}_{2(\mathrm{~s})}+2 \mathrm{FeS}_{(\mathrm{s})}+4 \mathrm{H}_{2} \mathrm{O}_{(\mathrm{l})}=\mathrm{Fe}_{3} \mathrm{O}_{4(\mathrm{~s})}+4 \mathrm{H}_{2} \mathrm{~S}_{(\mathrm{aq})}
\end{aligned}
$$

The influence of this mineral assemblage on the oxidation state of the fluid is reflected in the abundance of dissolved $\mathrm{H}_{2}$, which is directly related to $\mathrm{O}_{2}$ fugacity by the disproportionation of water, which rapidly attains thermodynamic equilibrium at high temperatures:

$$
\mathrm{H}_{2} \mathrm{O}_{(\mathrm{l})}=\mathrm{H}_{2(\mathrm{aq})}+0.5 \mathrm{O}_{2(\text { aq) }}
$$

The effectiveness of the PPM mineral assemblage in buffering dissolved $\mathrm{H}_{2}$ and $\mathrm{H}_{2} \mathrm{~S}$ concentrations on short (weekly) timescales has been demonstrated in numerous previous experiments (SEEWALD, 1994, 1997, 2001; MCCollom and SEewald, 2003b). Accordingly, aqueous $\mathrm{H}_{2} \mathrm{~S}$ was not routinely measured to preserve the limited quantities of fluid in the reaction cell. In addition to the above practical considerations, the choice of the PPM assemblage also reflects a reasonable redox state encountered in seafloor hydrothermal systems (which range from lower to much higher $f_{\mathrm{O} 2}$ values than the PPM triple point, SHOCK, 1992; SEYFRIED and DING, 1995; SEYFRIED et al., 2004) and provides a source of $\mathrm{S}$ for the formation of catalytic S species that may facilitate organic reactions (SEEWALD, 2001).

Each experiment was set up by loading a mixture containing $\sim 5 \mathrm{~g}$ each of commercially synthesized ( $>99.9 \%$ pure) pyrite, pyrrhotite and magnetite powders into the reaction cell with 
$\sim 30 \mathrm{~g}$ of an Ar purged solution of a given $\delta^{2} \mathrm{H}_{\mathrm{H} 2 \mathrm{O}}$ value. ${ }^{2} \mathrm{H}$-enriched and ${ }^{2} \mathrm{H}$-depleted solutions were made with dilutions of $99 \mathrm{wt} . \%{ }^{2} \mathrm{H}_{2} \mathrm{O}$ and ${ }^{2} \mathrm{H}$-depleted water (Cambridge Isotope Labs) with Milli-Q water, respectively. Both starting solutions contained a low but known concentration of $\mathrm{NaCl}$ to allow for detection of reaction cell leakage. Prior to pressurization of the reaction cell, the reaction cell gas headspace $(\sim 10 \mathrm{~mL})$ was purged repeatedly with $\mathrm{Ar}$, evacuated, then loaded with a gaseous mixture of $\mathrm{C}_{1}$ to $\mathrm{C}_{5} n$-alkanes of known $\delta^{2} \mathrm{H}$ (with approximately equimolar carbon amounts per $n$-alkane) that subsequently dissolved during pressurization. The purpose of including $\mathrm{CH}_{4}$ in the dissolved mixture was to examine if the lack of a corresponding alkene influenced exchangeability of $\mathrm{H}$ relative to the other $n$-alkanes. A small amount $(<1.5 \mathrm{~g})$ of starting solution was then injected to completely flush the gas mixture into the reaction cell for subsequent dissolution during pressurization and heating. It has been demonstrated that commercial minerals of the purity used here do contain trace carbon contaminants arising from synthesis processes (SEEWALD, 1994, 2001; MCCOLlOM and SEEWALD, 2003a,b). As a result, $\mathrm{C}_{1}$ to $\mathrm{C}_{5} n$-alkane concentrations employed in each experiment were intentionally $>2$ orders of magnitude larger than any contaminant hydrocarbon concentrations observed in previous studies to ensure $n$-alkane $\delta^{2} \mathrm{H}$ values $\left(\delta^{2} \mathrm{H}_{\text {alkane }}\right)$ during each experiment were unaffected by background levels.

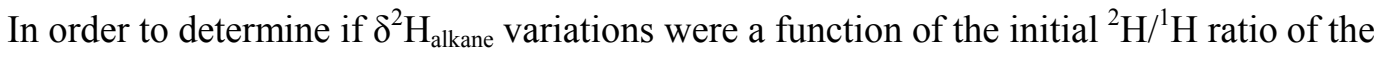
solution $\left(\delta^{2} \mathrm{H}_{\mathrm{H} 2 \mathrm{O}}\right)$, two experiments were conducted with near-identical temperatures, pressures and dissolved $n$-alkane concentrations but initial $\delta^{2} \mathrm{H}_{\mathrm{H} 2 \mathrm{O}}$ values higher and lower than the starting $\delta^{2} \mathrm{H}_{\text {alkane }}$ values, respectively. Experiment 1 (113 days) was conducted at $323^{\circ} \mathrm{C}$ and $36 \mathrm{MPa}$ with an initial $\delta^{2} \mathrm{H}_{\mathrm{H} 2 \mathrm{O}}$ of $+507 \%$, whereas Experiment $2\left(323^{\circ} \mathrm{C}\right.$ and $35 \mathrm{MPa}$ for 226 days $)$ had an initial $\delta^{2} \mathrm{H}_{\mathrm{H} 2 \mathrm{O}}$ value of $-802 \%$ during Stage (1). The reversibility of ${ }^{2} \mathrm{H} /{ }^{1} \mathrm{H}$ transfer between water and dissolved $n$-alkanes was confirmed by injecting $15.0 \mathrm{~g}$ of a ${ }^{2} \mathrm{H}$-spiked fluid (containing 
$10 \mathrm{mmol} / \mathrm{kg} \mathrm{NaCl}$ ) into the reaction cell of Experiment 2 after 226 days, thereby raising the $\delta^{2} \mathrm{H}_{\mathrm{H} 2 \mathrm{O}}$ value of the fluid to $+352 \%$ (Stage (2)). This had the effect of diluting the abundances of dissolved hydrocarbons by $\sim 50 \%$. The injected fluid was not purged of $\mathrm{O}_{2}$ with Ar gas prior to injection in order to limit evaporative effects on $\delta^{2} \mathrm{H}_{\mathrm{H} 2 \mathrm{O}}$ values.

\subsection{Analytical Methods}

Concentrations of dissolved species were monitored as a function of time during each experiment by removing discrete fluid aliquots (in duplicate, typically $<1 \mathrm{~g}$ each) into glass/PTFE gas-tight syringes for immediate analyses (within $2 \mathrm{~h}$ ). Prior to each sampling event, an initial aliquot $(<1 \mathrm{~g})$ was withdrawn to flush the capillary exit tube and discarded.

Concentrations of total dissolved inorganic carbon $\left(\Sigma \mathrm{CO}_{2}\right)$ and hydrocarbons $\left(\mathrm{C}_{1}\right.$ to $\mathrm{C}_{5} n$ alkanes, methylpropane (iso-butane) and $\mathrm{C}_{2}$ to $\mathrm{C}_{5} n$-alkenes) were determined using purge and trap gas chromatography. Fluid aliquots were injected into a sparge cell containing $\sim 1 \mathrm{~mL}$ of $25 \mathrm{wt} . \%$ phosphoric acid to completely purge $\Sigma \mathrm{CO}_{2}$. The evolved gases were cryofocussed on $n$ octane-coated silica beads then transferred directly to a HP 5890 Series II gas chromatograph (GC) equipped with Porapak ${ }^{\mathrm{TM}} \mathrm{Q}$ column and serially connected thermal conductivity (TCD) and flame ionization (FID) detectors. Commercially available hydrocarbon and $\mathrm{CO}_{2}$ gas standards were similarly cryofocussed and transferred to the GC column for calibration. Chromatographic separation of individual $\mathrm{C}_{4}$ and $\mathrm{C}_{5} n$-alkene isomers in experimental samples was not possible by this method and reported concentrations therefore reflect the summation of all alkene isomers (denoted as $\Sigma \mathrm{C}_{\mathrm{X}}$ alkenes, where $\mathrm{X}$ is the carbon number) eluting at the retention time of the corresponding terminal $n$-alkene standard. Furthermore, due to the co-elution of large methylpropane and $n$-butane peaks before and after comparatively small $\Sigma \mathrm{C}_{4}$ alkene peaks, large errors are associated with concentrations of the latter. Accordingly, while their presence was 
observed, they were not quantified. Analytical uncertainties (2s) are $\pm 5 \%$ for $\mathrm{C}_{1}$ to $\mathrm{C}_{5} n$-alkanes and $\Sigma \mathrm{CO}_{2}$, and $\pm 10 \%$ for alkenes and methylpropane.

Aqueous $\mathrm{H}_{2}$ analyses were performed on a HP 5890 Series II GC by injection of extracted headspace gases from fluid aliquots onto a $5 \AA$ molecular sieve column with TCD detection (analytical error $(2 \mathrm{~s}) \pm 10 \%)$. Total dissolved sulfide $\left(\Sigma \mathrm{H}_{2} \mathrm{~S}\right)$ was determined gravimetrically for a single fluid sample at 218.8 days in Experiment 2, following acidification of the aliqout with a $25 \mathrm{wt} . \%$ phosphoric acid solution and precipitation of evolved $\mathrm{H}_{2} \mathrm{~S}$ gas as $\mathrm{Ag}_{2} \mathrm{~S}$ in a $5 \mathrm{wt} . \% \mathrm{AgNO}_{3}$ solution. $\mathrm{pH}\left(\right.$ at $25^{\circ} \mathrm{C}$ and $1 \mathrm{~atm}$ ) was also not monitored routinely but was measured potentiometrically on a single (1.4g) fluid sample at 287.9 days in Experiment 2 using a $\mathrm{Ag} / \mathrm{AgCl}$ combination reference electrode. Concentrations of $\mathrm{Cl}$ and any dissolved $\mathrm{C}_{1}$ to $\mathrm{C}_{5} n$ alkanoic acids formed were determined by ion chromatography on a Dionex DX500 system with electrochemical detection using an IonPac ${ }^{\circledR}$ AS15 ion exchange and IonPac ${ }^{\circledR}$ ICE-AS1 ion exclusion column, respectively. Analytical uncertainties (2s) are $\pm 5 \%$ for $\mathrm{Cl}$ and $\pm 10 \%$ for $n$ alkanoic acids.

Fluid aliquots for isotope analyses of dissolved hydrocarbons were also collected in glass gas-tight syringes and immediately transferred into evacuated glass serum vials with butyl rubber stoppers (BellCo Glass) until analyzed. To avoid contamination of samples by background levels of low molecular weight hydrocarbons present in butyl rubber, the stoppers were treated to avoid contamination by volatile organic compounds by boiling in $2 \mathrm{~N} \mathrm{NaOH}$ for $2-4 \mathrm{hrs}$ followed by rinsing and overnight immersion in Milli-Q water (OREMLAND et al., 1987). $\delta^{2} \mathrm{H}_{\text {alkane }}$ values for methane, ethane, propane, $n$-butane and $n$-pentane were determined by continuous flow Gas Chromatography/Pyrolysis/Isotope-Ratio Mass Spectrometry (GC/P/IRMS) on a Finnigan Delta ${ }^{\text {Plus }}$ XL mass spectrometer at WHOI interfaced to an Agilent 6890 GC through a GCCIII interface. The pyrolysis furnace was held at $1440^{\circ} \mathrm{C}$ for quantitative conversion of carbon-bound 
$\mathrm{H}$ to $\mathrm{H}_{2}$. Peaks of an organic working standard gas (propane, $\delta^{2} \mathrm{H}_{\text {alkane }}=-150 \%$, externally calibrated against V-SMOW and SLAP) were periodically introduced downstream of the analytical (Alltech AT-Q) column for pyrolytic conversion as per analyte peaks prior to entry into the IRMS ion source. Mass-2 and -3 signals were processed using the ISODAT software package (ThermoElectron) and corrected for the $\mathrm{H}_{3}{ }^{+}$factor $(<5 \mathrm{ppm} / \mathrm{mV})$ daily (SESSIONS, 2006). While the pooled standard deviation ( 2 s precision) of all hydrocarbon $\delta^{2} \mathrm{H}$ analyses is less than $\pm 6 \%$, it is difficult to estimate the overall accuracy of our analyses given that the range of $\delta^{2} \mathrm{H}$ values reported here $\left(-489 \%\right.$ to $+114 \%$ ) is beyond that of any available LMW hydrocarbon $\delta^{2} \mathrm{H}$ standards. Although we have corrected for $\mathrm{H}_{3}{ }^{+}$production (an important source of bias), other effects of 'scale compression' (COPLEN, 1988) are possible for the extreme compositions encountered during our experiments. One potential source of inaccuracy that has been demonstrated in GC/P/IRMS analyses are 'memory effects', whereby a peak in a given chromatogram may be influenced by a preceding adjacent peak which differs in $\delta^{2} \mathrm{H}$ by several hundred \%o (WANG and SESSIONS, 2008). WANG and SESSIONS (2008) attribute such effects to uncharacterized GC (i.e. column) and surface adsorption processes during pyrolytic conversion, and while they have been constrained for lipid $\delta^{2} \mathrm{H}$ analyses the potential effects for analyses of LMW $n$-alkanes with extreme $\delta^{2} \mathrm{H}$ values are unknown. However, introduction of reference propane peaks of constant composition between analyte peaks of extreme $\delta^{2} \mathrm{H}$ values within chromatograms from both experiments suggests variability due to pyrolytic conversion is less than $\pm 10 \%$ for samples with the most extreme differences between $n$-alkane isotopic compositions.

The hydrogen isotope composition of water in experimental solutions $\left(\delta^{2} \mathrm{H}_{\mathrm{H} 2 \mathrm{O}}\right)$ was determined using high-resolution laser absorption spectroscopy (DLT-100 Liquid Water Isotope Analyzer, Los Gatos Research Inc.) according to the method of WANG et al. (2009a). Precisions 
were less than $\pm 4 \%$ o (2s) for all analyses. Independent analysis of the ${ }^{2} \mathrm{H}$-enriched starting solution for Experiment 1 by conventional dual-inlet isotope-ratio mass spectrometry (Isotech Laboratories, Inc.) indicated a $\delta^{2} \mathrm{H}_{\mathrm{H} 2 \mathrm{O}}$ value of $+501 \pm 5 \%$, which is close to the value obtained by laser absorption spectroscopy $(507 \pm 4 \%$ ).

All $\delta^{2} \mathrm{H}$ values are expressed relative to the Vienna Standard Mean Ocean Water (VSMOW) scale by the relation:

$$
\delta^{2} \mathrm{H}=\left[\left({ }^{2} \mathrm{H} /{ }^{1} \mathrm{H}\right)_{\text {MEAS }} /\left({ }^{2} \mathrm{H} /{ }^{1} \mathrm{H}\right)_{\text {VSMOW }}\right]-1
$$

where MEAS refers the measured isotope ratio for a given bulk molecule and $\left({ }^{2} \mathrm{H} /{ }^{1} \mathrm{H}\right)_{\text {VSMOw }}$ is $155.76 \times 10^{-6}$ (HAGEMANN et al., 1970). The permil (\%o) symbol used with $\delta^{2} \mathrm{H}$ values implies a factor of $10^{3}$ which is omitted from Eq. (5). 


\section{RESULTS}

\section{$3.1^{2} \mathrm{H} /{ }^{1} \mathrm{H}$ ratios}

Based on $\mathrm{H}$ mass balance considerations, it is impossible for the composition of the water to change within analytical error due to isotope exchange with the dissolved hydrocarbons. This is confirmed by measurements of the initial (-802\%o and $+352 \%$ ) and final $(-798 \%$ and $+354 \%)$ $\delta^{2} \mathrm{H}_{\mathrm{H} 2 \mathrm{O}}$ values of both stages of Experiment 2 (Table 4.2). A mean value for each stage was therefore assumed. Though only one sample was taken, the above observation suggests that $\delta^{2} \mathrm{H}_{\mathrm{H} 2 \mathrm{O}}$ values in Experiment $1(+507 \%)$ are unlikely to have varied outside of error and the value determined by laser absorption spectroscopy was used for consistency.

Several patterns of variability were observed during the experiments in the rates and directions of $\mathrm{C}_{1}$ to $\mathrm{C}_{5} n$-alkane $\delta^{2} \mathrm{H}$ changes (Figure 4.2). Firstly, the direction of change clearly varied depending upon the value of $\delta^{2} \mathrm{H}_{\mathrm{H} 2 \mathrm{O}} . \delta^{2} \mathrm{H}$ values of all $n$-alkanes increased to varying degrees with time during Experiment 1 from initial values that were lower than that of the solution. In Stage (1) of Experiment 2, where initial $n$-alkane $\delta^{2} \mathrm{H}$ values were initially much higher than that of the solution, the reverse occurred. These trends were reversed for all $n$ alkanes except $\mathrm{CH}_{4}$ following injection of ${ }^{2} \mathrm{H}_{2} \mathrm{O}$-spiked water to raise the $\delta^{2} \mathrm{H}$ value of the reaction cell water above that of the $n$-alkanes (Figure 4.2). Secondly, rates of $\delta^{2} H$ variation were consistently faster for the $\mathrm{C}_{3}$ to $\mathrm{C}_{5} n$-alkanes relative to ethane (Figure 4.2). Methane $\delta^{2} \mathrm{H}$ values varied least in both experiments with only a small increases and decreases $(<30 \%)$ evident, although in all cases the direction conformed to the higher homologues (Figure 4.2). $\delta^{2} \mathrm{H}$ values for both compounds behaved in a similar fashion in both stages of Experiment 2, with negligible changes in $\delta^{2} \mathrm{H}$ for methane and a slight increases or decreases for ethane.

Regardless of the $\delta^{2} \mathrm{H}_{\mathrm{H} 2 \mathrm{O}}$ value, the rate of change of $\delta^{2} \mathrm{H}_{\text {alkane }}$ values consistently decreased with time for the $\mathrm{C}_{3}$ to $\mathrm{C}_{5} n$-alkanes. Such decreases in the rate of change of $\delta^{2} \mathrm{H}_{\text {alkane }}$ 
were not discernable for methane and ethane on the timescales of the experiments. In addition, rates of change for the $\mathrm{C}_{3}$ to $\mathrm{C}_{5} n$-alkanes varied depending on the difference between the $\delta^{2} \mathrm{H}_{\mathrm{H} 2 \mathrm{O}}$

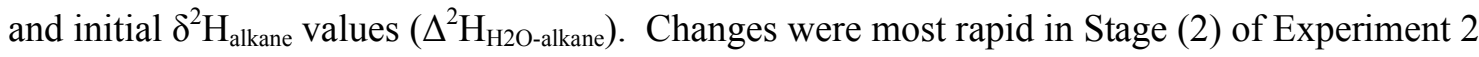
$\left(\Delta^{2} \mathrm{H}_{\mathrm{H} 2 \mathrm{O}-\mathrm{alkane}}\right.$ of $\left.780-840 \%\right)$ and were slowest in Experiment $1\left(\Delta^{2} \mathrm{H}_{\mathrm{H} 2 \mathrm{O}-\text { alkane }}\right.$ of $600-640 \%$ ), with Stage (1) of Experiment 2 having intermediate rates and $\Delta^{2} \mathrm{H}_{\mathrm{H} 2 \mathrm{O}-\text { alkane. }}$

\subsection{Dissolved species concentrations}

\subsection{1 $\mathrm{H}_{2}$ and $\mathrm{H}_{2} \mathrm{~S}$ concentrations}

Concentrations of all dissolved species analyzed are shown in Table 4.1. Aqueous $\mathrm{H}_{2}$ concentrations ranged from 0.26 to $0.65 \mathrm{mmol} / \mathrm{kg}$ during both experiments. Assuming activity coefficients of 1 for neutral species, the narrow range of dissolved $\mathrm{H}_{2}$ activities $\left(a_{\mathrm{H} 2(\mathrm{aq})}\right)$ in both Experiments 1 and 2 overlaps the $a_{\mathrm{H} 2 \text { (aq) }}$ predicted by the triple point of the PPM mineral assemblage (Figure 4.1). The effectiveness of the assemblage in buffering the redox state of the fluid is evident in the rapid restoration of $a_{\mathrm{H} 2 \text { (aq) }}$ to predicted values after fluid injection in Experiment 2. Based on the single $\mathrm{H}_{2} \mathrm{~S}$ measurement in Experiment 2, the PPM assemblage also appears to have buffered the activity of $\mathrm{H}_{2} \mathrm{~S}_{(\mathrm{aq})}$ to near equilibrium values (Figure 4.1), consistent with previous experimental observations (SEEWALD, 1994, 2001; MCCOLLOM and SEEWALD, 2003b).

\subsubsection{Dissolved hydrocarbon concentrations}

With the exception of this first sampling event in Experiment 1, and taking into account the dilution effects of $\mathrm{H}_{2} \mathrm{O}$ injection in Experiment 2, the abundances of methane, ethane and propane were relatively constant (within error) throughout both experiments (Figure 4.3). Gradual decreases in the concentrations of $n$-pentane and $n$-butane were observed with time in 
Experiment 1 and during both stages of Experiment 2 (Table 4.1). Maximum overall losses in any given stage were $<55 \%$ for $n$-pentane and $<20 \%$ for $n$-butane. $\mathrm{C}_{1}$ to $\mathrm{C}_{5} n$-alkane concentrations at 8.0 days in Experiment 1 were all $25 \%$ lower than subsequent sampling events (Table 4.1). No such trend was observed in the $\mathrm{Cl}$ concentration over the same period and the same behavior was not observed in Experiment 2. This suggests that the solution may have been inhomogeneous with respect to the dissolved $n$-alkane mixture during the initial phase of Experiment 1, rather than addition of buffer-derived contaminant hydrocarbons. The pressure vessels are not equipped to ensure stirring/mixing of reaction cell contents and poor mixing of the starting solution and dissolved gases during loading the $n$-alkane mixture could have been responsible. Alternatively, operator error may have been responsible.

Concentrations of ethene and propene varied by less than a factor of 2 during both experiments (Figure 4.4). $\Sigma \mathrm{C}_{5}$ alkenes initially increased with time during the first stage of Experiment 2 but did not vary substantially during the second stage or during Experiment 1. Gradual production of small amounts of methylpropane was observed in both experiments (Table 4.1).

\subsection{3 $\mathrm{\Sigma CO}_{2}$ and organic acid concentrations}

The high concentrations of $\Sigma \mathrm{CO}_{2}$ initially observed in both experiments $(0.85-$ $1.4 \mathrm{mmol} / \mathrm{kg}$, Table 4.1) most likely reflect thermocatalytic production of $\mathrm{CO}_{2}$ from contaminant carbon in the mineral assemblage. Production during the early stages of experiments was observed in previous investigations which used the PPM assemblage (SEEWALD, 1994, 2001; MCCOLLOM and SEEWALD, 2003b). Thereafter however, $\Sigma \mathrm{CO}_{2}$ increased gradually in both experiments, including Stage (2) of Experiment 2 (Figure 4.3). Excluding the first sampling events, mass balance on total dissolved carbon species $\left(C_{T}\right.$, Table 4.1$)$ indicates that $C_{T}$ is 
relatively invariant after the initial stages of both experiments. Therefore the mineral buffer cannot account for the gradual increases $\Sigma \mathrm{CO}_{2}$ with time in both experiments. Sluggish oxidation of $\mathrm{C}_{4}$ and $\mathrm{C}_{5}$ hydrocarbons (as evidenced by their gradual decreases) is the most likely candidate to explain the formation of $\Sigma \mathrm{CO}_{2}$ and is consistent with observations from previous experiments (SEEWALD, 2001). Increased $\Sigma \mathrm{CO}_{2}$ likely contributed to the acidic $\mathrm{pH}\left(4.2\right.$ at $25^{\circ} \mathrm{C}$ and $\left.1 \mathrm{~atm}\right)$ observed in Experiment 2.

Gradual accumulation of ethanoic and propanoic acid were observed throughout both experiments at concentrations $<0.5 \mathrm{mmol} / \mathrm{kg}$ (Table 4.1). Propanoic acid, though identified, was not present in quantifiable concentrations (above $0.1 \mathrm{mmol} / \mathrm{kg}$ ) except in the later part of Stage (1) of Experiment 2. As is the case for $\Sigma \mathrm{CO}_{2}$, organic acids are also typical alteration products of $n$ alkane oxidation and formation of exclusively $\mathrm{C}_{2}$ and $\mathrm{C}_{3} n$-alkanoic acids is consistent with the decomposition of $\mathrm{C}_{4}$ and $\mathrm{C}_{5}$ n-alkanes (SEEWALD, 2001). After injection of $\mathrm{H}_{2} \mathrm{O}$ into the reaction cell contents in Experiment 2 (Table 4.1), the concentration of ethanoic acid decreased by $<20 \%$ which is smaller than expected for the estimated dilution factor (2.1). In addition, decreases in $n$ pentane and $n$-butane (both $\sim 70 \%$ ) after dilution were smaller than expected. While the excess carbon present as ethanoic acid relative to that predicted by dilution $(\sim 0.4 \mathrm{mmol} \mathrm{C} / \mathrm{kg})$ fails to account for all $\mathrm{C}$ apparently lost from the $\mathrm{C}_{4}$ and $\mathrm{C}_{5}$ alkanes after dilution $(\sim 1.2 \mathrm{mmol} \mathrm{C} / \mathrm{kg})$, it does suggest that some oxidation of the latter occurred upon injection of $\mathrm{H}_{2} \mathrm{O}$, which was not sparged of $\mathrm{O}_{2}$. Minor increases in propanoic acid and $\mathrm{\Sigma CO}_{2}$ below analytical resolution may account for much of the remainder. Despite these losses, however, no significant changes in $\delta^{2} \mathrm{H}$ values for $n$-butane and $n$-pentane were apparent, indicating that any decomposition had a minimal isotopic effect relative to the large observed variations in $\delta^{2} \mathrm{H}$ values for these compounds. 


\section{DISCUSSION}

\subsection{Alkane-alkene equilibria}

The extent to which ethane-ethene and propane-propene attained a state of thermodynamic equilibrium in both experiments can be demonstrated by calculating chemical affinities $(A)$ according to the following relationship:

$$
A(\mathrm{~kJ} / \mathrm{mol})=-\mathrm{RT} \ln \left(Q_{r} / K_{e q}\right)
$$

Where $R$ is the universal gas constant, $T$ is temperature in Kelvin, $Q_{r}$ and $K_{e q}$ are the reaction quotient and equilibrium constant for the form of reaction (1) in question at $T$ and experimental pressure. Positive values of $A$ indicate a thermodynamic drive for the reaction to proceed from left to right as written. At thermodynamic equilibrium, values of $Q$ and $K_{e q}$ are equal and the affinity reduces to zero. Uncertainties associated with affinity calculations are difficult to quantify, but based on errors in the derivation of $\Delta_{r} G^{o}$ values (SHOCK and HELGESON, 1990) calculated affinities of $0 \pm 4 \mathrm{~kJ} / \mathrm{mol}$ can in many cases be assumed to reflect attainment of equilibrium. As shown in Figure 4.5, thermodynamic affinities for ethane-ethene and propanepropene equilibria rapidly approached values within $4 \mathrm{~kJ} / \mathrm{mol}$ of zero in both experiments. These affinities were consistently maintained for both reactions with time and were rapidly restored following injection of $\mathrm{H}_{2} \mathrm{O}$ in Experiment 2. Thus, as demonstrated by SEEWALD (2001), metastable thermodynamic equilibrium was attained between $\mathrm{C}_{2}$ and $\mathrm{C}_{3} n$-alkanes and their corresponding terminal $n$-alkenes according to reaction (1) in both experiments.

Rapid equilibration of $\mathrm{C}_{4}$ and $\mathrm{C}_{5} n$-alkanes and their corresponding $n$-alkenes is also likely to have occurred in both experiments, but it is difficult to demonstrate equilibrium for these reactions due to the potential for isomerization of alkenes. Numerous studies have shown that terminal alkene double bonds can migrate internally in aliphatic hydrocarbons (HOERING, 1984; WERES et al., 1988; SISKIN et al., 1990; LEIF and SiMONEIT, 1995, 2000; SEEWALD, 2001, 2001). 
However, thermodynamic data for internal $n$-alkenes are lacking and analytical limitations precluded quantification of individual $\mathrm{C}_{4}$ and $\mathrm{C}_{5} n$-alkene isomers in this study. For example, affinities for equilibrium between pentane and 1-pentene were in excess of $-20 \mathrm{~kJ} / \mathrm{mol}$ for both experiments (Figure 4.4), which suggests an apparent excess of the latter relative to equilibrium predictions. This discrepancy is best explained by the presence of isomers other than 1-pentene (i.e. cis-2-pentene and trans-2-pentene) which contribute to the $\Sigma \mathrm{C}_{5} n$-alkene measurement. While contributions from branched $\mathrm{C}_{5}$ alkene isomers (2-methylbut-1-ene, 3-methylbut-1-ene and 2-methylbut-2-ene) cannot be excluded, precursors for such compounds (likely branched $\mathrm{C}_{5}$ alkanes) were not observed in substantial quantities in this study or previous experimental investigations (SEEWALD, 2001).

\subsection{Reversible ${ }^{2} \mathrm{H} /{ }^{1} \mathrm{H}$ exchange and isotopic equilibrium}

\subsubsection{Alkane-alkene equilibrium and ${ }^{2} H /{ }^{\prime} H$ exchange}

Experiments 1 and 2 demonstrate that the coupling of alkane-alkene equilibrium and water disproportionation (reactions (1) and (4)) represents an indirect but reversible mechanism for ${ }^{2} \mathrm{H} /{ }^{1} \mathrm{H}$ exchange between water and $\mathrm{C}_{2+} n$-alkanes under hydrothermal conditions. $\mathrm{H}$ transfer to and from $n$-alkanes is facilitated by the sluggish nature of the stepwise oxidation pathway at the redox state employed, as demonstrated by the persistence of $n$-alkanes in solution. Relatively minor amounts of $n$-alkene are present at equilibrium relative to their corresponding $n$-alkanes (Table 4.1), and while kinetic isotope effects associated with the hydration of $n$-alkenes to alcohols are possible, they cannot explain the large reversible isotopic shifts demonstrated in the experiments. The losses (in excess of dilution) of $n$-butane and $n$-pentane observed upon injection of $\mathrm{H}_{2} \mathrm{O}$ in Experiment 2 (Section 3.2.3) produced no noticeable change in $\delta^{2} \mathrm{H}$ values 
(Figure 4.2), suggesting that any inherent kinetic isotope effects are insignificant relative to the large shifts produced by alkane-alkene equilibrium.

According to SESSIONS et al. (2004), mechanisms by which ${ }^{2} \mathrm{H} /{ }^{1} \mathrm{H}$ ratios in organic molecules are altered by incorporation of exogenous $\mathrm{H}$ can be classified into five general categories. These consist of 'pure exchange' (where reactants and products are isotopically different but structurally and chemically identical), 'stereochemical exchange' (isotopic substitutions related to chiral inversions), 'constitutional exchange' (where reactants and products are constitutional isomers), and net transfer mechanisms such as 'addition' and 'loss' in which a reaction leads to a net transfer of $\mathrm{H}$ to or from the molecule. When viewed in isolation, the conversion of $n$-alkanes to $n$-alkenes technically implies an H 'loss' reaction (and the reverse 'addition') in the above classification. However, the requisite $\mathrm{H}_{2(\mathrm{aq})}$ for alkene hydrogenation is ultimately provided by the disproportionation of water (reaction (4)) and both reactions (1) and (4) are rapid and reversible at elevated temperatures (SEEWALD, 1994, 2001). Hence, though the actual ${ }^{2} \mathrm{H} /{ }^{1} \mathrm{H}$ exchange takes place by a sequence of 'loss' and subsequent 'addition' transfer mechanisms, when coupled together reversible $\mathrm{H}$ transfer between water and $n$-alkanes is analogous to a 'pure exchange' mechanism in the absence of competing side reactions.

Overall exchange may be further enhanced by 'constitutional exchange' within the $n$ alkenes ( $\mathrm{C}_{3}$ and above) prior to hydrogenation back to their corresponding $n$-alkanes. It is widely acknowledged that terminal double bonds in aliphatic alkenes can rapidly migrate (i.e. isomerize) to internal positions under acidic conditions at elevated temperatures. SEEWALD (2001) observed rapid isomerization of 1-butene to all possible $n$-butene isomers on timescales of hours at $300^{\circ} \mathrm{C}$ following injection of the former into a PPM-buffered solution. Extensive double bond migration has also been demonstrated in several studies during hydrous pyrolysis of $\mathrm{C}_{10}, \mathrm{C}_{14}$ and $\mathrm{C}_{16}$ terminal alkenes, leading to substantial ${ }^{2} \mathrm{H}$ incorporation where pure ${ }^{2} \mathrm{H}_{2} \mathrm{O}$ was used (HOERING, 
1984; WERES et al., 1988; SISKIN et al., 1990; LEIF and SIMONEIT, 1995, 2000). Double bond migration is known to be catalyzed by high $\mathrm{H}^{+}$activities (and possibly $\mathrm{S}$ species) and ionic strengths, suggesting it is the result of an ionic reaction mechanism (SISKIN et al., 1990; LEIF and SIMONEIT, 2000). Variations in $\Sigma \mathrm{C}_{5} n$-alkene concentrations with time during both experiments (Figure 4.4) were minor, which suggests pentane may have achieved a state of metastable equilibrium with multiple individual $n$-alkene isomers though thermodynamic data do not exist to confirm this possibility. Hydrogenation of internal double bonds would therefore contribute to exchange on internal carbon positions in $n$-alkanes. As shown in Figure 4.6, both alkene isomerization and internal double bond hydrogenation imply that $\mathrm{H}$ at all carbon positions in an individual $n$-alkane is potentially exchangeable when considered within the framework of the overall alkane-alkene reaction.

A key observation from the experiments is the drastic difference in isotopic shifts for the $\mathrm{C}_{3+}$ hydrocarbons relative to ethane (Figure 4.2). While isomerization processes are undoubtedly a contributing factor, additional influences may also contribute to the rapid exchange in higher $n$ alkanes relative to ethane. One possible factor is that the equilibrium abundance of $n$-alkenes according to reaction (1) is substantially greater for $\mathrm{C}_{3+} n$-alkanes than ethane. While in all cases metastable chemical equilibrium is attained, the rate at which isotopic exchange occurs will depend in part on the abundance of species involved in the exchange reaction. An examination of the equilibrium constants for reaction (1) shows that equilibrium constant for a given temperature are over an order of magnitude higher for the reactions of $\mathrm{C}_{3+} n$-alkanes than ethane (Figure 4.7), implying equivalently lower alkane/alkene activity ratios at a given $a_{\mathrm{H} 2(\mathrm{aq})}$. Thus, higher alkane/alkene ratios may slow overall rates of exchange between water and $n$-alkanes. 


\subsubsection{Isotopic equilibrium and alkane $\delta^{2} H$ trends}

Regardless of the $\delta^{2} \mathrm{H}$ value of the solution, changes in the $\mathrm{H}$ isotope composition of the $\mathrm{C}_{3}$ to $\mathrm{C}_{5} n$-alkanes slowed with time in both experiments (Figure 4.5). The absence of steady state $\delta^{2} \mathrm{H}$ values, notwithstanding, this behavior provides compelling evidence that isotope equilibrium was being approached between some, if not all, of the $n$-alkanes and water. This is entirely consistent with the reversible nature of the alkane-alkene and water disproportionation reactions. When a reservoir of $\mathrm{H}($ alkane $\mathrm{H})$ is approaching isotopic equilibrium with another reservoir that is vastly in excess (i.e. water), the rate of change of ${ }^{2} \mathrm{H} /{ }^{1} \mathrm{H}$ ratios tends to follow pseudo first-order kinetics. SESSIONS et al. (2004, after ROBERTS and UREY, 1939) described this process by the general equation:

$$
\frac{F_{t}-F_{e q}}{F_{i}-F_{e q}}=e^{-k t}
$$

Where $F$ is the fractional abundance of ${ }^{2} \mathrm{H}\left(={ }^{2} \mathrm{H} /\left({ }^{2} \mathrm{H}+{ }^{1} \mathrm{H}\right)\right)$ in the organic molecule initially, at time $t$, and at equilibrium and $k$ refers to the rate constant of exchange. The equilibrium isotope fractionation factor can be derived from $F_{e q}$ and the $\delta^{2} \mathrm{H}_{\mathrm{H} 2 \mathrm{O}}$ value. The left hand side of this equation essentially represents the fraction of $\mathrm{H}$ atoms that remain unexchanged at time $t$, and at time $i$ the left hand side equals 1 and approaches zero as $t \rightarrow \infty$. For $n$-alkanes, both the $F_{e q}$ and $k$ terms in the strictest sense will depend on the nature of carbon-bound $\mathrm{H}$ in question (i.e. methyl or methylene-bound $\mathrm{H}$ ) and while equation (7) is exact for methane and ethane, more complex forms considering individual $\mathrm{H}$ positions are required to accurately model exchange in larger hydrocarbons (SESSIONS et al., 2004). However, while the above equation refers to a 'pure exchange' scenario, the bulk $\mathrm{H}$ in $\mathrm{C}_{2+} n$-alkanes will follow the form of equation (7) resulting in decreasing $\delta^{2} \mathrm{H}$ changes in the bulk molecule per unit time as overall isotopic composition of alkane $\mathrm{H}$ nears an equilibrium state. Factors such as equilibrium alkane, alkene and $\mathrm{H}_{2}$ activities, 
alkene isomerization and other possible catalytic species, however, will undoubtedly influence the magnitude of the observed rate constant $k$ for exchange $\left(k_{o b s}\right)$ in the bulk $n$-alkane molecule. Because of the exponential nature of the process, observed exchange rates will also vary depending on how far the bulk $\delta^{2} \mathrm{H}$ value is from the equilibrium state at a given $k_{\text {obs }}$. Pseudo first-order behavior was not evident for ethane in the timescales of either experiment. However, it is possible that the sluggish rate of exchange compared to the $\mathrm{C}_{3^{+}} \mathrm{n}$-alkanes is simply the manifestation of low ethene abundance and resulting effects on $k_{o b s}$ rather than proximity to equilibrium.

Significant advances have been made in theoretical predictions of equilibrium isotope fractionation factors $\left(\alpha_{o / w}\right)$ between organic and water $\mathrm{H}$ (defined as the ratio of their respective isotopic ratios $\left.\left(R_{o} / R_{w}\right)\right)$ but these have been limited to low temperatures (KNYAZEV, 1992; SESSIONS et al., 2004; SCHIMMELMANN et al., 2006; WANG et al., 2009a,b). Presently, little is known about the magnitude of $\alpha_{o / w}$ for $\mathrm{C}_{1}$ to $\mathrm{C}_{5} n$-alkanes at conditions typical of hydrothermal systems and natural gas deposits. WANG et al. $(2009 \mathrm{a}, \mathrm{b})$ recently derived estimates of $\alpha_{o / w}$ between 0 and $100^{\circ} \mathrm{C}$ for specific $\mathrm{H}$ moieties in a variety of organic compound classes, including linear alkanes and alkenes, using $a b$ initio quantum mechanical calculations combined with experimental calibration to reduce uncertainties associated with the former. According to their estimates, $\mathrm{C}_{1}$ to $\mathrm{C}_{5} n$-alkanes should be between 105 and $122 \%$ depleted in ${ }^{2} \mathrm{H}$ relative to $\mathrm{V}$ SMOW at $100^{\circ} \mathrm{C}$. Fractionation factors for the $\mathrm{C}_{3+} n$-alkanes show little temperature dependence $\left(<10 \%\right.$ ) over the $100^{\circ} \mathrm{C}$ calibrated range (WANG et al., 2009b). While isotopic equilibrium was not attained in either of the experiments presented here, minimum values of $\alpha_{o / w}$ can be estimated for propane, $n$-butane and $n$-pentane based on their final $\delta^{2} \mathrm{H}$ values according to the expression:

$$
\alpha_{o / w}=\frac{R_{o}}{R_{w}}=\frac{\delta^{2} H_{\text {alkane }}+1000}{\delta^{2} H_{H 2 O}+1000}
$$


Calculated minimum $\alpha_{o / w}$ values are $0.673,0.708$ and 0.739 , respectively, for propane, $n$-butane and $n$-pentane in Experiment 1. In all likelihood the actual $\alpha_{o / w}$ values could be much higher but

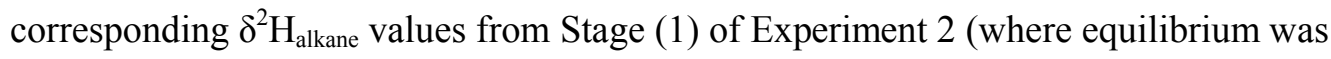
approached from the opposite direction) only limit $\alpha_{o / w}$ values to less than $\sim 4$. Given the comparatively sluggish changes in ethane and methane $\delta^{2} \mathrm{H}$ values, these calculations do not provide useful lower limits on $\alpha_{o / w}$ values for these compounds.

\subsubsection{Variations in $\delta^{2} H_{\text {meth }}$}

Despite the lack of a comparable exchange mechanism, minor shifts $(<30 \%)$ were observed in methane $\delta^{2} \mathrm{H}$ values that followed the direction of the higher hydrocarbons. While it is possible that these trends reflect sluggish exchange of methane $\mathrm{H}$ by some mechanism involving $\mathrm{H}$ abstraction and replacement, we cannot exclude additions of $\mathrm{CH}_{4}$ from degradation of isotopically exchanged $\mathrm{C}_{4}-\mathrm{C}_{5} n$-alkanes or other sources. Minor amounts of methane can be produced as an end product of the stepwise $n$-alkane oxidation pathway if decomposition of any acetic acid produced occurs by decarboxylation to $\mathrm{CO}_{2}$ and $\mathrm{CH}_{4}$ (KHARAKA et al., 1983; PALMER and DRUMMOND, 1986; Bell et al., 1994; SEEWALD, 2001). SEEWALD (2001) noted that ratios of $\mathrm{CO}_{2}$ to $\mathrm{CH}_{4}$ produced during $n$-heptane degradation were substantially higher under PPMbuffered conditions relative to more oxidizing conditions, indicating enhanced decarboxylation of acetic acid under more reducing conditions. Methane concentrations remained constant during both experiments except for the initial sample in Experiment 1 (Figure 4.3), and so contributions of methane within analytical error are required to have produced the observed isotopic shifts if exchange is not responsible. Based on the $2 \mathrm{~s}$ analytical uncertainties of $\mathrm{CH}_{4}$ concentrations, a maximum of $\sim 0.3 \mathrm{mmol} \mathrm{CH}_{4} / \mathrm{kg}$ could have been produced in Experiment 1. Isotope mass balance indicates that to produce the observed $+28 \%$ shift in $\delta^{2} \mathrm{H}_{\text {meth }}$ values requires added $\mathrm{CH}_{4}$ to 
have a $\delta^{2} \mathrm{H}$ value of $\sim 380 \%$. Similar calculations for Stage (1) of Experiment 2 indicate that production of $\sim 0.2 \mathrm{mmol} \mathrm{CH}_{4} / \mathrm{kg}$ (within $2 \mathrm{~s}$ uncertainty) would require $\delta^{2} \mathrm{H}_{\text {meth }}$ values of approximately $-600 \%$ in the added $\mathrm{CH}_{4}$. In both cases the required $\mathrm{CH}_{4}$ compositions are between the $\delta^{2} \mathrm{H}$ values of the water and the $\mathrm{C}_{3}-\mathrm{C}_{5}$ hydrocarbons. Production of methyl groups with such extreme ${ }^{2} \mathrm{H} /{ }^{1} \mathrm{H}$ ratios implies extensive intramolecular isotopic ordering in the heavily exchanged longer $n$-alkanes. Alternative possibilities include thermocatalytic production of labeled methane from carbon contaminants in the mineral buffer (SEEWALD, 1994). It is therefore equivocal whether the small shifts in $\mathrm{CH}_{4}$ observed in this study truly represent reversible exchange.

\subsection{Implications for natural systems}

\subsection{1 ${ }^{2} \mathrm{H} /{ }^{1} \mathrm{H}$ ratios and abiogenesis in igneous environments}

The abiogenic formation of aliphatic hydrocarbons during hydrothermal alteration of ultramafic crust has been extensively discussed (ABRAJANO et al., 1988; SHERWOOD et al., 1988; ABrAjANO et al., 1990; ChARlou et al., 2002; ProskUROWSKI et al., 2006; MCCOLlOM and SEEWALD, 2007; KonN et al., 2009). Though the exact mechanism for production of $n$-alkanes in highly-reducing crustal fluids is uncertain, it is assumed to be analogous to the industrial Fischer-Tropsch reaction and involves both reduction of inorganic carbon $\left(\mathrm{CO}_{2}\right.$ or $\left.\mathrm{CO}\right)$ to methyl/methylene moieties and subsequent polymerization on a catalytic mineral surface (see review in MCCOLLOM and SEEWALD, 2007). In the last decade, ${ }^{2} \mathrm{H} /{ }^{1} \mathrm{H}$ ratios have been used to elucidate this phenomenon in addition to stable carbon isotope ratios (SHERWOOD LOLLAR et al., 2002; FU et al., 2007; PROSKUROWSKI et al., 2008). Because of the larger relative mass

difference between ${ }^{2} \mathrm{H}$ and ${ }^{1} \mathrm{H}$, substantial kinetic $\mathrm{H}$ isotope fractionation could occur between homologues during abiogenic polymerization. As a result of investigations of putative abiogenic 
$\mathrm{C}_{1}-\mathrm{C}_{4} n$-alkanes recovered from saline fracture waters in crystalline basement rocks of the Canadian Shield, SHERWOOd LOLLAR et al. (2002) proposed a characteristic H isotope trend with carbon number whereby $\delta^{2} \mathrm{H}_{\text {meth }}$ values (often below -400\%) are extremely low relative to the $\mathrm{C}_{2-}$ $\mathrm{C}_{4}$ alkanes $\left(\delta^{2} \mathrm{H} \sim-220\right.$ to $-320 \%$ ), which show a trend of increasing $\delta^{2} \mathrm{H}$ with increasing carbon number (Figure 4.8). This trend has subsequently been observed in several other Precambrian shield gases (SHERWOOD LOLLAR et al., 2006, 2008) and is postulated to reflect preferential cleavage of ${ }^{12} \mathrm{C}-{ }^{1} \mathrm{H}$ bonds relative to ${ }^{12} \mathrm{C}-{ }^{2} \mathrm{H}$ bonds during the abiogenic polymerization process, putative kinetic effects associated with ${ }^{13} \mathrm{C} /{ }^{12} \mathrm{C}$ fractionation during polymerization.

The trends presented by SHERWOOD LOLLAR et al. $(2002,2006,2008)$ have not been observed in purported abiogenic hydrocarbons from higher temperature settings (Figure 4.8), such as those present in vent fluids of the Lost City hydrothermal site (PROSKUROWSKI et al., 2008) or those formed in abiotic synthesis experiments (FU et al., 2007), leading to speculation that this reflects mechanistic differences. Based on the experimental observations of reversible exchange presented here, this discrepancy may actually reflect partial or complete alkane-water $\mathrm{H}$ isotope exchange in the latter cases. The recent advent of theoretical equilibrium fractionation factors for $\mathrm{C}_{2+}$ alkane $\mathrm{H}$ below $100^{\circ} \mathrm{C}$ mentioned above (WANG et al., 2009a,b), combined with $\alpha_{\mathrm{o} / \mathrm{w}}$ values for $\mathrm{CH}_{4}-\mathrm{H}_{2} \mathrm{O}$ equilibrium (HORIBE and CRAIG, 1995) permits an evaluation of possible alkanewater equilibrium in the Canadian Shield gases and Lost City hydrothermal fluids. Using published $\delta^{2} \mathrm{H}_{\mathrm{H} 2 \mathrm{O}}$ values, apparent values of $\alpha_{o / w}$ can be calculated from equation (8) for the Canadian shield (Kidd Creek Mine, SHERWOOD LollaR et al., 2002) and Lost City vent fluid $n$ alkanes (PROSKUROWSKI et al., 2008) at the reported temperatures in these studies.

As shown in Figure 4.9, the Kidd Creek Mine $n$-alkanes are far too depleted in ${ }^{2} \mathrm{H}$ relative to theoretical predictions for isotopic equilibrium with water. $\alpha_{o / w}$ for other low temperature $\left(<100^{\circ} \mathrm{C}\right)$ microbial/abiogenic LMW $n$-alkanes from crystalline rock aquifers in the 
Witwatersrand Basin, S. Africa (WARD et al., 2004; LIN et al., 2006; ONSTOTT et al., 2006; SHERWOOD LOLLAR et al., 2008) and Fennoscandian Shield (NURMI et al., 1988; SHERWOOD LOLLAR et al., 1993a,b) are also much lower than equilibrium predictions at the temperatures likely experienced by these systems. As previously suggested by SHERWOOD et al. (1988) and SHERWOOD LOLLAR et al. (1993b), the most likely explanation for the extremely negative $\delta^{2} \mathrm{H}$ values of these hydrocarbons is that they formed by abiogenic or microbial reductive processes (likely at low temperatures) involving extremely ${ }^{2} \mathrm{H}$-depleted $\mathrm{H}_{2(\mathrm{aq})}\left(\delta^{2} \mathrm{H}_{\mathrm{H} 2}\right.$ values as low as 695\%) that is present in these systems (SHERWOOD et al., 1988; SHERWOOD LOLLAR et al., 1993b; LIN et al., 2006). Though some isotopic exchange cannot be discounted, the apparent lack of isotopic equilibrium between water and alkane $\mathrm{H}$ in these gases is reasonable given that the alkane-alkene mechanism may not be able to effectively promote $\mathrm{H}$ exchange in $\mathrm{C}_{2+}$ hydrocarbons at the low temperatures of the these systems $\left(\sim 35-60^{\circ} \mathrm{C}\right.$, SHERWOOD LOLLAR et al., 2008). The drastic decrease in alkene stability according to reaction (1) with decreasing temperature (Figure 4.7), coupled with potential kinetic barriers for chemical equilibrium inherent at the low temperatures of these systems may simply preclude attainment of isotopic equilibrium despite the exceedingly long timescales of fluid isolation in these systems (on the order of tens of Ma, LIPPMANN et al., 2003).

In stark contrast to the Precambrian shield gases, abiogenic $\mathrm{C}_{1}$ to $\mathrm{C}_{3} n$-alkanes in vent fluids at Lost City are much more ${ }^{2} \mathrm{H}$-enriched $\left(\delta^{2} \mathrm{H}\right.$ of -119 to $-171 \%$, PROSKUROWSKI et al., $2008)$ and at odds with the extremely negative $\delta \mathrm{H}$ values of $\mathrm{H}_{2(\mathrm{aq})}$ there $(-600$ to $-700 \%$, PROSKUROWSKI et al., 2006) by the above reasoning. While these differences could reflect higher temperatures of abiogenesis or mechanistic effects, a likely explanation is that partial or near-complete alkane-water exchange has erased any highly ${ }^{2} \mathrm{H}$-depleted signatures. $\alpha_{o / w}$ values for many of the Lost City fluids are slightly low relative to predictions (Figure 4.9) but are much 
closer to apparent alkane-water equilibrium than the Kidd Creek gases and $\alpha_{\text {ethane/w }}$ values are in agreement with equilibrium values in some of the lower temperature fluids. The likelihood of ethane-water isotopic equilibrium mediated by reaction (1) is further supported by measurements of ethene concentrations in these fluids (1-40nmol $/ \mathrm{kg}$, PROSKUROWSKI et al., 2008). Using the range of endmember ethane, ethene and $\mathrm{H}_{2}$ concentrations reported by PROSKUROWSKI et al. (2008) apparent temperatures of ethane-ethene equilibrium according to reaction (1) are all $>300^{\circ} \mathrm{C}$, indicating substantial ethane-ethene disequilibrium at the observed vent temperatures $\left(<91^{\circ} \mathrm{C}\right)$. However, there is extensive theoretical evidence to suggest that Lost City fluids have cooled conductively during upflow and are considerably hotter (in the vicinity of $250^{\circ} \mathrm{C}$ ) at depth (AlLEN and SEYFried, 2004; Foustoukos et al., 2008). It is therefore possible that the ethaneethene reaction records higher temperatures deeper in the hydrothermal system due to a lack of re-equilibration upon cooling, as has been observed in the Middle Valley hydrothermal system (CRUSE and SEEWALD, 2006). The discrepancy of apparent isotopic equilibrium between ethane and water at the lower temperatures of venting but lack of chemical ethane-ethene equilibrium could be explained if alkane $\alpha_{\mathrm{o} / \mathrm{w}}$ values are similarly insensitive to changing temperature above $100^{\circ} \mathrm{C}$. While the alkane-alkene mechanism cannot promote $\mathrm{CH}_{4}-\mathrm{H}_{2} \mathrm{O}$ exchange, the ${ }^{2} \mathrm{H}$-enriched nature of $\mathrm{CH}_{4}$ is also suggestive of isotopic equilibrium at temperatures significantly greater than measured values. Many of the $\alpha_{\mathrm{o} / \mathrm{w}}$ values for $\mathrm{CH}_{4}$ at Lost City $(0.849-0.877$, Figure 4.9$)$ are higher than the predicted values of HORIBE and CRAIG (1995) below $100^{\circ} \mathrm{C}$, but are suggestive of $\mathrm{CH}_{4}-\mathrm{H}_{2} \mathrm{O}$ isotopic equilibrium within a temperature range of $140-280^{\circ} \mathrm{C}$. While the derivation of HORIBE and CRAIG (1995) lacks experimental verification, this range is consistent with the above estimates of reaction zone conditions (ALLEN and SEYFRIED, 2004; FOUSTOUKOS et al., 2008). Furthermore, higher temperature isotopic equilibrium between the pairs $\mathrm{CH}_{4}-\mathrm{H}_{2}$ and $\mathrm{H}_{2} \mathrm{O}-\mathrm{H}_{2}$, as proposed by PROSKUROWSKI et al. (2006), inherently implies $\mathrm{CH}_{4}-\mathrm{H}_{2} \mathrm{O}$ equilibrium. 
Results of the experiments suggest that, with increasing temperatures, alkane-alkene equilibria may promote $\mathrm{H}$ isotopic exchange and possibly equilibrium between abiogenic $n$ alkanes and water. In other ultramafic-hosted hydrothermal systems where abiogenic hydrocarbon formation has been proposed, such as Rainbow and Logatchev (HOLM and CHARLOU, 2001; CHARLOU et al., 2002; SCHMIDT et al., 2007), reaction zone temperatures are considerably higher than Lost City. Maximum measured vent fluid temperatures at both of these locations are in excess of $350^{\circ} \mathrm{C}$ and reaction zone conditions are thought to be nearer $400^{\circ} \mathrm{C}$ (ALLEN and SEYFRIED, 2003; SEYFRIED et al., 2004). The experiments presented here suggest substantial $\mathrm{H}$ isotope exchange between the $\mathrm{C}_{2+}$ alkanes and water can occur on timescales of months to years at $323^{\circ} \mathrm{C}$, and even greater rates of isotope exchange are likely at the higher temperatures of these systems due to the enhanced stability of alkenes (Figure 4.7) according to reaction (1). Although greater alkene abundances could enhance overall stepwise oxidation of $n$ alkanes according to the mechanism of SEEWALD (2001), the highly reducing conditions evident in these systems (SEYFRIED et al., 2004) may sufficiently retard oxidation such that, as was observed in the experiments presented here, isotopic exchange proceeds much faster than competing chemical degradation reactions. Given that estimates of crustal residence times for hydrothermal solutions based on radioisotope methods (KADKO, 1996; KADKO and BUTTERFIELD, 1998) and geophysical considerations (FISHER, 2003) are on the order of years, sufficient time for isotopic equilibrium may be provided. Though $\mathrm{H}$ isotope data are lacking for $\mathrm{C}_{2+}$ alkanes at sites other than Lost City, the demonstration of ethane-ethene and propane-propene equilibria at reaction zone conditions in the sedimented Middle Valley hydrothermal system (CRUSE and SEEWALD, 2006) suggests that alkane-water exchange may be commonplace in hydrothermal fluids with measurable $\mathrm{C}_{2+} n$-alkanes. Hence, the alkane ${ }^{2} \mathrm{H}$-depletions noted by SHERWOOD LOLLAR et al. (2002) are unlikely to be evident among abiogenic hydrocarbons in seafloor 
hydrothermal fluids and may be a unique feature of Precambrian Shield gases. This is consistent with the only experimental study to date on $\mathrm{H}$ isotope variations during Fischer-Tropsch-type synthesis, which did not observe any ${ }^{2} \mathrm{H}$ depletion in methane relative to ethane at $400^{\circ} \mathrm{C}$ (Figure 4.8). Should such depletions be noted in hydrocarbons from higher temperature hydrothermal systems, ambiguities could arise if partial exchange has occurred only in the higher $\left(\mathrm{C}_{2+}\right)$ hydrocarbons but exchange in methane has been sluggish.

\subsection{2 ${ }^{2} \mathrm{H} / \mathrm{H}$ signatures in thermogenic hydrocarbons}

In environments where hydrocarbon formation is occurring by thermogenic processes, the potential for alkene-mediated $\mathrm{H}$ exchange between LMW $n$-alkanes and water will clearly depend on the availability of aqueous fluids, in addition to redox and temperature. Water is a ubiquitous feature in sedimentary basins and there is substantial evidence to suggest it plays an important role in both the thermal maturation of sedimentary organic matter and the migration of generated light $\left(<\mathrm{C}_{5}\right)$ hydrocarbons (LEWAN et al., 1979; TISSOT and WELTE, 1984; LEWAN, 1997). In addition, oil and gas deposits are invariably associated with basinal brine fluids of connate or infiltrated paleometeoric origin (KHARAKA and CAROTHERS, 1986). LMW n-alkanes are among the more soluble constituents of petroleum and, in some cases, can be extensively removed from discrete hydrocarbon phases by processes such as water washing (TISSOT and WELTE, 1984; HuNT, 1996). The efficacy of exchange will also depend on the redox state of aqueous fluids in which hydrocarbons are dissolved due to the nature of the alkane-alkene reaction. Though buffered redox conditions are a necessary experimental tool, they are not a prerequisite for oxidation of alkanes to alkenes (SEEWALD, 2001). All that is required is the availability of sufficient oxidizing agents to consume $\mathrm{H}_{2}$ (which would accumulate given the dominating effect of organic matter of fluid redox) and create a thermodynamic drive that maintains alkene stability. 
SEEWALD (2001) reviewed several possible oxidants that are known to be present in sedimentary basins, including $\mathrm{SO}_{4}$, which is present in evaporite minerals and as a major ion in basinal brines (KHARAKA and CAROTHERS, 1986), Fe(III)-bearing minerals such as aluminosilicates, hematite and magnetite (SURDAM and CROSSEY, 1985; SURDAM et al., 1993) and pyrite (which can react with $\mathrm{H}_{2}$ and $\mathrm{CO}_{2}$ to form $\mathrm{FeCO}_{3}$ and $\mathrm{H}_{2} \mathrm{~S}$ ), all of which can consume $\mathrm{H}_{2}$ by being reduced. If conditions are sufficiently reducing such that stepwise oxidation occurs much slower than alkanealkene equilibration, then $\mathrm{H}$ exchange between undegraded alkanes and water could conceivably proceed. The temperature dependence of alkane/alkene ratios will also influence the likelihood of exchange. However, while light $\left(<\mathrm{C}_{10}\right)$ hydrocarbons typically form below $\sim 200^{\circ} \mathrm{C}$ where alkene stability may be orders of magnitude lower (Figure 4.7) according to reaction (1), the slow timescales of thermal maturation and migration in petroleum-producing systems (on the order of Ma) may be sufficient to facilitate isotopic exchange.

Despite the advent of compound-specific ${ }^{2} \mathrm{H} /{ }^{1} \mathrm{H}$ analyses, there have been relatively few published studies of $\delta^{2} \mathrm{H}$ values of thermogenic $\mathrm{C}_{2}-\mathrm{C}_{5}$ alkanes. However, common features of thermogenic natural gases reported to date are gradually increasing $\delta^{2} \mathrm{H}$ values with increasing carbon number (see Figure 4.8) and overall ${ }^{2} \mathrm{H}$-enrichment in the homologous series with increasing thermal maturity (SCHOELL, 1983; BARKER and POLLOCK, 1984; WHITICAR et al., 1985; SHERWOOD LOLLAR et al., 2002; EDWARDS et al., 2007; BOREHAM et al., 2008). As is the case for the higher $n$-alkanes, this is traditionally viewed as the kinetic isotope effect of $\mathrm{C}-\mathrm{C}$ bond cleavage which favors reaction of ${ }^{2} \mathrm{H}$-depleted larger molecules in cracking reactions (SCHIMMELMANN et al., 2004). C $\left({ }^{2} \mathrm{H}^{1} \mathrm{H}\right)-\mathrm{C}\left({ }^{1} \mathrm{H}_{2}\right)$ bonds are stronger, and therefore considered slower to react, than $\mathrm{C}\left({ }^{1} \mathrm{H}_{2}\right)-\mathrm{C}\left({ }^{1} \mathrm{H}_{2}\right)$ bonds and quenching of generated alkyl radicals is likely to favor incorporation of ${ }^{1} \mathrm{H}$ relative to ${ }^{2} \mathrm{H}$ (SACKETT, 1978; SCHIMMELMANN et al., 2004). 
Both the typical ${ }^{2} \mathrm{H}$ depletions reported for thermogenic gases and the trend of gradually increasing $\delta^{2} \mathrm{H}$ with carbon number are, however, equally consistent with isotopic equilibration with water $\mathrm{H}$. Taking the example of thermogenic wet $\left(\mathrm{C}_{2+}\right.$ rich $)$ gases from southwestern Ontario reported by SHERWOOD LOLLAR et al. $(1994,2002), \mathrm{C}_{2+}$ alkanes there are depleted in ${ }^{2} \mathrm{H}$ relative to average saline groundwaters of this region by between $70-140 \%$ (apparent $\alpha_{\mathrm{o} / \mathrm{w}}$ values of approximately 0.85 to 0.92 ). This depletion overlaps the range of equilibrium fractionation factors (Figure 4.9) derived by WANG et al. (2009b) at $100^{\circ} \mathrm{C}\left(\alpha_{\mathrm{o} / \mathrm{w}}\right.$ values of $\left.0.87-0.89\right)$. If the equilibrium $\alpha_{\mathrm{o} / \mathrm{w}}$ values for alkane $\mathrm{H}$ are similarly insensitive to temperature up to $200^{\circ} \mathrm{C}$, the likely temperatures of maturation (SHERWOOD LOLLAR et al., 1994), the compositions of these gases would be consistent with equilibrium exchange with water. In addition to these depletions, the gradual increase of $\sim 0-30 \%$ with each increase in carbon number that is typical of all reported thermogenic gases (SHERWOOD LOLLAR et al., 2002; EDWARDS et al., 2007; BOREHAM et al., 2008) could be explained by the predicted chain length dependency of alkane-water equilibrium $\mathrm{H}$ isotope effects. According to the data of WANG et al. (2009b), calculated $\alpha_{o / w}$ values for ethane/water (0.878), propane/water (0.886), $n$-butane/water (0.890) and $n$ pentane/water $(0.895)$ equilibrium at $100^{\circ} \mathrm{C}$ also increase with carbon number. While the magnitude of these offsets increases at lower temperatures ( $c f$. Figure 4.9) the trend does not change. This chain length dependency is related to the inductive electron-donating $(+\mathrm{I})$ effect of terminal methyl $\left(-\mathrm{CH}_{3}\right)$ groups on adjacent internal methylene $\left(-\mathrm{CH}_{2}-\right)$ positions which increases stiffness in $\mathrm{C}-\mathrm{H}$ bonds of the latter, thereby favoring slightly greater degrees of ${ }^{2} \mathrm{H}$ substitution (HARTSHORN and SHINER, 1972; WANG et al., 2009b). With increasing chain lengths beyond $n$ pentane, this effect gradually decreases due to increasing quantities of internal methylene groups (with uniform $\alpha_{o / w}$ values) but it has the capability to produce strikingly similar trends to those observed in thermogenic LMW hydrocarbons. 
While hydrocarbons beyond $\mathrm{C}_{5}$ were not examined in this investigation, experimental evidence suggests that alkane-alkene reactions could also mediate extensive $\mathrm{H}$ exchange in much longer chain alkanes. In a series of hydrous pyrolysis experiments using pure ${ }^{2} \mathrm{H}_{2} \mathrm{O}$ at $330-350^{\circ} \mathrm{C}$, LEIF and SIMONEIT (2000) demonstrated extensive double bond migration and concomitant ${ }^{2} \mathrm{H}$ incorporation during reaction of the terminal alkenes 1,13-tetradecadiene $\left(\mathrm{C}_{14} \mathrm{H}_{26}\right)$ and 1hexadecene $\left(\mathrm{C}_{16} \mathrm{H}_{32}\right)$ with immature organic-rich shale. These short experiments $(<72 \mathrm{~h})$ were conducted in traditional fixed volume reactors without intentional redox buffering but minor amounts of ${ }^{2} \mathrm{H}$-labeled alkanes were observed to form by reduction of these probe molecules. This strongly suggests that reversible alkane-alkene reactions enabled $\mathrm{H}$ isotope exchange in $\mathrm{C}_{10}-$ $\mathrm{C}_{16}$ hydrocarbons in the presence of the highly reducing shale and its kerogen complement, suggesting that this mechanism is not limited to the shorter chain homologues. This is especially significant given the clear chain length dependency of exchange rates observed in the experiments here. It has become increasingly recognized in recent years that $\delta^{2} \mathrm{H}$ values of bulk sedimentary organic matter and its individual hydrocarbon constituents initially increase during thermal maturation but approach relatively a constant offset of $\sim 80-110 \%$ o below that of associated waters, even with further increases in thermal maturity (SCHIMMELMANN et al., 1999, 2001, 2006). The estimation of compound specific fractionation factors between alkane $\mathrm{H}$ and water lead WANG et al. (2009b) to conclude that this offset can best be explained by isotopic exchange toward equilibrium between these two H reservoirs. While SCHIMMELMANN et al. $(1999,2001)$ argued that this exchange likely takes place as a result of reactions largely limited to the maturation process (e.g. cracking, isomerization, rearrangement etc.), the alkane-alkene mediated exchange demonstrated here could easily occur subsequent to the main stage of oil formation and would also allow for comprehensive exchange of all aliphatic $\mathrm{H}$ in hydrocarbons. 
Further constraints are required to confirm that the composition of thermogenic LMW hydrocarbons reflects isotopic equilibrium with associated waters. These include detailed evaluations of the isotopic composition of individual thermogenic gas constituents and associated waters in the context of their thermal history, in addition to better estimates of alkane-water fractionations at higher temperatures to confirm if temperature independence. However, the observations of near equilibrium isotopic compositions in at least some thermogenic gases and the increased recognition of exchange in higher molecular weight petroleum constituents provides compelling evidence that the $\mathrm{H}$ isotopic composition of thermogenic hydrocarbons may be governed by equilibrium rather than kinetic isotope effects both during maturation processes. This has important implications for the use of hydrogen isotopes as maturity indicators and correlation parameters for thermogenic hydrocarbons (TANG et al., 2005, 2007). Whereas the extent of isotopic fractionation during kinetically controlled processes will vary as a function of time and temperature, equilibrium fractionation will only vary as a function of temperature and to a lesser extent pressure. 


\section{CONCLUSIONS}

This chapter presents experimental evidence of ${ }^{2} \mathrm{H} /{ }^{1} \mathrm{H}$ exchange between low molecular weight $\left(<\mathrm{C}_{5}\right)$ aqueous $n$-alkanes and water under hydrothermal conditions. Transfer of $\mathrm{H}$ isotopes is mediated by rapid reversible metastable equilibria between $n$-alkanes and their corresponding $n$-alkenes, coupled with the disproportionation of water which ultimately provides requisite $\mathrm{H}$ for hydrogenation. In the absence of competing subsequent oxidation of $n$-alkenes, rates of exchange are sufficiently rapid that drastic changes in alkane $\delta^{2} \mathrm{H}$ values timescales of years at $323^{\circ} \mathrm{C}$. Much faster rates of exchange are observed for longer chains alkanes due to factors such as higher equilibrium alkene abundances and internal isomerization of terminal $n$-alkenes prior to hydrogenation. The evidence for exchange in methane is equivocal, but if it occurs, rates are substantially slower than the higher homologues.

Based on recent theoretical estimates of equilibrium fractionation between hydrocarbon $\mathrm{H}$ and water $\mathrm{H}$, previously reported gases from the Canadian Shield of putative abiogenic origin are too depleted in ${ }^{2} \mathrm{H}$ relative to equilibrium fractionation effects and are thus unlikely to have experienced extensive exchange with water. This is consistent with thermodynamic predictions of exceedingly high equilibrium alkane/alkene ratios which would hinder exchange at the low temperatures $\left(<60^{\circ} \mathrm{C}\right)$ experienced by these aqueous hydrocarbons. Abiogenic hydrocarbons from the higher temperature Lost City hydrothermal field are, in contrast, more likely to have undergone exchange following synthesis at reaction zone conditions. The proximity of many of these hydrocarbon ${ }^{2} \mathrm{H} /{ }^{1} \mathrm{H}$ ratios to values predicted for isotopic equilibrium with water suggests that the observed disparity between these and the Canadian Shield hydrocarbons reflects exchange effects subsequent to abiogenesis. Though further confirmation is needed, the $\mathrm{H}$ isotopic composition of many thermogenic gases is also suggestive isotopic equilibrium with water, rather than kinetic isotope effects related to thermal maturation. This is consistent with the 
emerging realization of extensive exchange in higher petroleum hydrocarbons that have experienced elevated temperatures. 


\section{ACKNOWLEDGEMENTS}

The author wished to thank Prof. Alex Sessions for kindly undertaking the hydrogen isotopic analyses of water samples from this study. Sean Sylva carried out hydrogen isotope analyses of hydrocarbon samples. This work was funded by DOE Grant DE-FG02-97ER14746 and NSF grant OCE-0549829. 


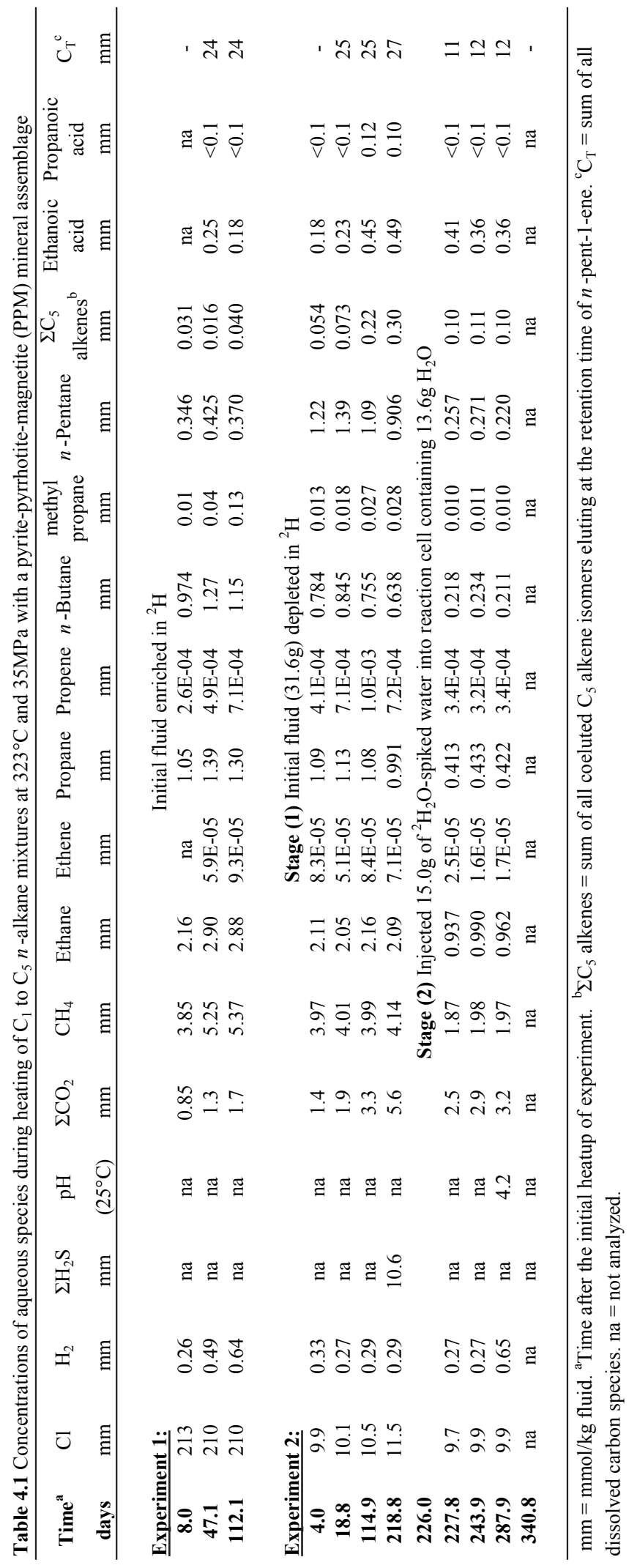


Table 4.2 Hydrogen isotope compositions of dissolved $\mathrm{C}_{1}$ to $\mathrm{C}_{5} n$-alkanes and corresponding solutions during heating with a pyrite-pyrrhotite-magnetite (PPM) mineral assemblage

\begin{tabular}{cccccccc}
\hline Time $^{\mathrm{a}}$ & Temp. & Solution & Methane & Ethane & Propane & $n$-Butane $n$-Pentane \\
days & ${ }^{\circ} \mathrm{C}$ & $\delta^{2} \mathrm{H}_{\mathrm{H} 2 \mathrm{O}}(\%)$ & $\delta^{2} \mathrm{H}(\%)$ & $\delta^{2} \mathrm{H}(\%)$ & $\delta^{2} \mathrm{H}(\%)$ & $\delta^{2} \mathrm{H}(\%)$ & $\delta^{2} \mathrm{H}(\%)$ \\
\hline
\end{tabular}

Experiment 1: Initial fluid enriched in ${ }^{2} \mathrm{H}$

$\begin{array}{cccccccc}\mathbf{0 . 0} & - & 507 & -194 & -142 & -113 & -136 & -93.9 \\ \mathbf{8 . 0} & 324 & \text { na } & -194 & -144 & -100 & -100 & -54.0 \\ \mathbf{4 7 . 1} & 324 & \text { na } & -190 & -115 & -14.6 & -4.87 & 28.7 \\ \mathbf{1 1 2 . 1} & 323 & \text { na } & -162 & -91.7 & 14.4 & 66.7 & 114\end{array}$

Experiment 2: Initial fluid depleted in ${ }^{2} \mathrm{H}$

\begin{tabular}{|c|c|c|c|c|c|c|c|}
\hline 0.0 & - & -802 & -165 & -142 & -113 & -136 & -93.9 \\
\hline 4.0 & 323 & na & -165 & -144 & -156 & -157 & -116 \\
\hline 18.8 & 323 & na & -166 & -152 & -190 & -198 & -174 \\
\hline 114.9 & 323 & na & -188 & -186 & -346 & -408 & -398 \\
\hline 218.8 & 323 & -798 & -187 & -233 & -430 & -490 & -473 \\
\hline 226.0 & \multicolumn{7}{|c|}{---------- Injected ${ }^{2} \mathrm{H}_{2} \mathrm{O}$-spiked solution --------- } \\
\hline 227.8 & 323 & 352 & -215 & -248 & -429 & -489 & -478 \\
\hline 243.9 & 323 & na & -212 & -248 & -363 & -401 & -393 \\
\hline 287.9 & 323 & na & -213 & -238 & -249 & -246 & -243 \\
\hline 340.8 & 323 & $\mathrm{na}^{\mathrm{b}}$ & -208 & -219 & -158 & -118 & -83.7 \\
\hline
\end{tabular}

${ }^{\mathrm{a}}$ Time after the initial heatup of experiment. Initial (time zero) $\delta^{2} \mathrm{H}$ values are those prior to loading of materials into reaction cell. ${ }^{\mathrm{b}} \mathrm{The} \delta^{2} \mathrm{H}_{\mathrm{H} 2 \mathrm{O}}$ value determined after termination of Expt. 2 was $+354 \%$. 


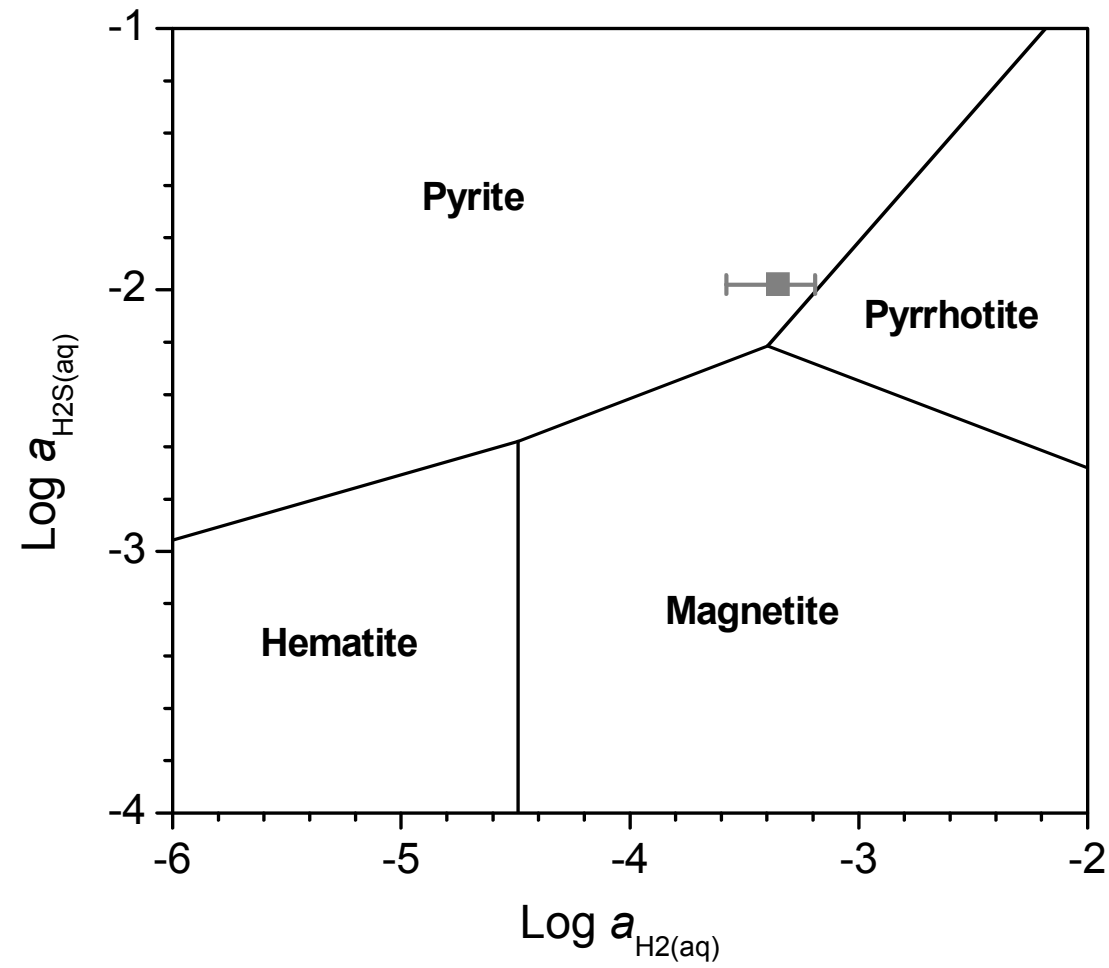

Figure 4.1. Activity diagram showing the phase relations in the system $\mathrm{Fe}-\mathrm{S}-\mathrm{O}-\mathrm{H}$ at $325^{\circ} \mathrm{C}$ and $35 \mathrm{MPa}$. Requisite data for the construction of this figure were obtained from the SUPCRT92 database (JOHNSON et al., 1992). Because pyrrhotite is non-stoichiometric, equilibrium constants for reactions (2) and (3) in Section 2.1 reduce to $a_{\mathrm{H} 2(\mathrm{aq})} / a_{\mathrm{FeS}(\mathrm{s})} 1.5$ and $a_{\mathrm{H} 2 \mathrm{~S}(\mathrm{aq})} / a_{\mathrm{FeS}(\mathrm{s})}{ }^{2}$. To calculate equilibrium values of $a_{\mathrm{H} 2(\mathrm{aq})}$ and $a_{\mathrm{H} 2 \mathrm{~S}(\mathrm{aq})}$ requisite activities for pyrrhotite at conditions were calculated from the data of TOULMIN and BARTON (1964). The horizontal gray line denotes the range of aqueous $\mathrm{H}_{2}$ activities observed during both Experiments 1 and 2. The gray square denotes the concentration of $\mathrm{H}_{2} \mathrm{~S}$ measured in a single sample at 218.8 days in Experiment 2. 

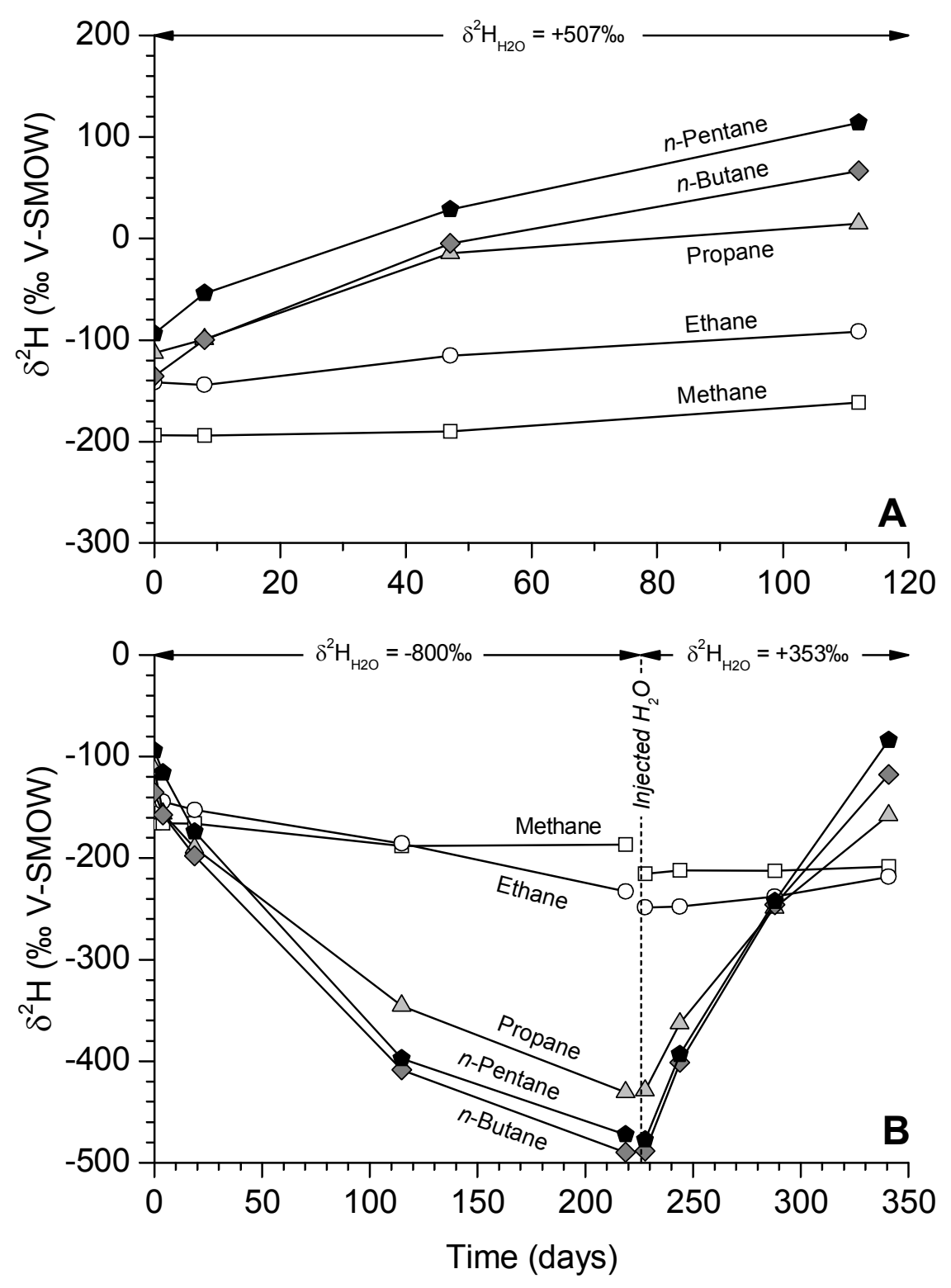

Figure 4.2. $\mathrm{C}_{1}$ to $\mathrm{C}_{5} n$-alkane $\delta^{2} \mathrm{H}$ values from Experiment 1 (A) and Experiment 2 (B) as a function of time at $323^{\circ} \mathrm{C}$ and $35 \mathrm{MPa}$. The vertical dashed line at 226 days in Experiment 2 represents injection of ${ }^{2} \mathrm{H}-$ spiked water to raise the $\delta^{2} \mathrm{H}_{\mathrm{H} 2 \mathrm{O}}$ value of the solution in the reaction cell. The pooled standard deviation of all $n$-alkane $\delta^{2} \mathrm{H}$ analyses $( \pm 6 \%, 2 \mathrm{~s})$ is smaller than the data symbols. Mean values of $\delta^{2} \mathrm{H}_{\mathrm{H} 2 \mathrm{O}}$ are plotted for each experimental stage. 

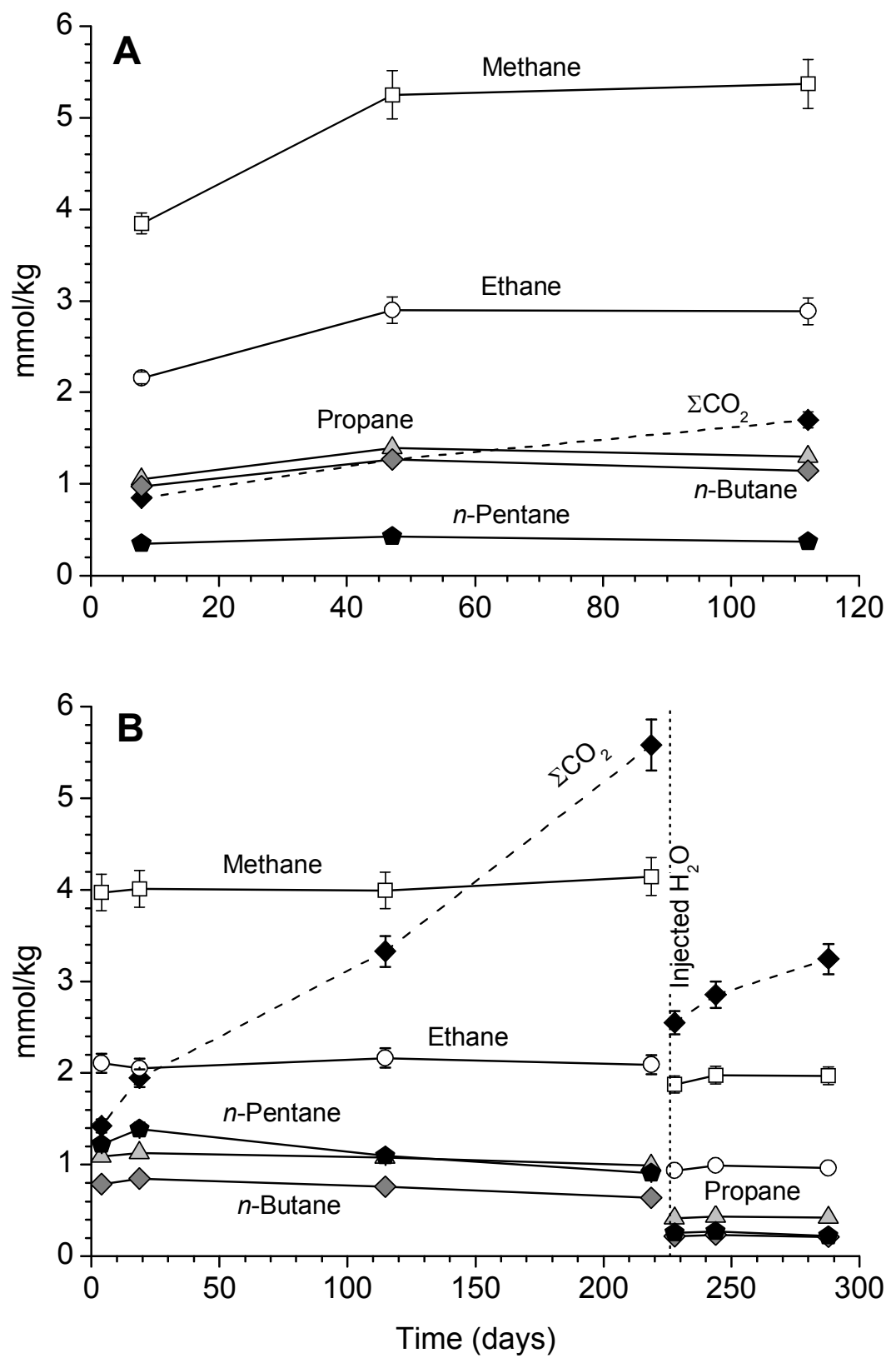

Figure 4.3. Concentrations of $\mathrm{C}_{1}$ to $\mathrm{C}_{5} n$-alkanes and $\Sigma \mathrm{CO}_{2}$ from Experiment 1 (A) and Experiment 2 (B) as a function of time at $323^{\circ} \mathrm{C}$ and $35 \mathrm{MPa}$. The vertical dashed line at 226 days in Experiment 2 represents injection of ${ }^{2} \mathrm{H}$-spiked water. Error bars represent $2 \mathrm{~s}$ analytical uncertainties, which are smaller than the data symbols for propane, $n$-butane and $n$-pentane. Concentrations of dissolved species were not monitored after 300 days in Experiment 2. 

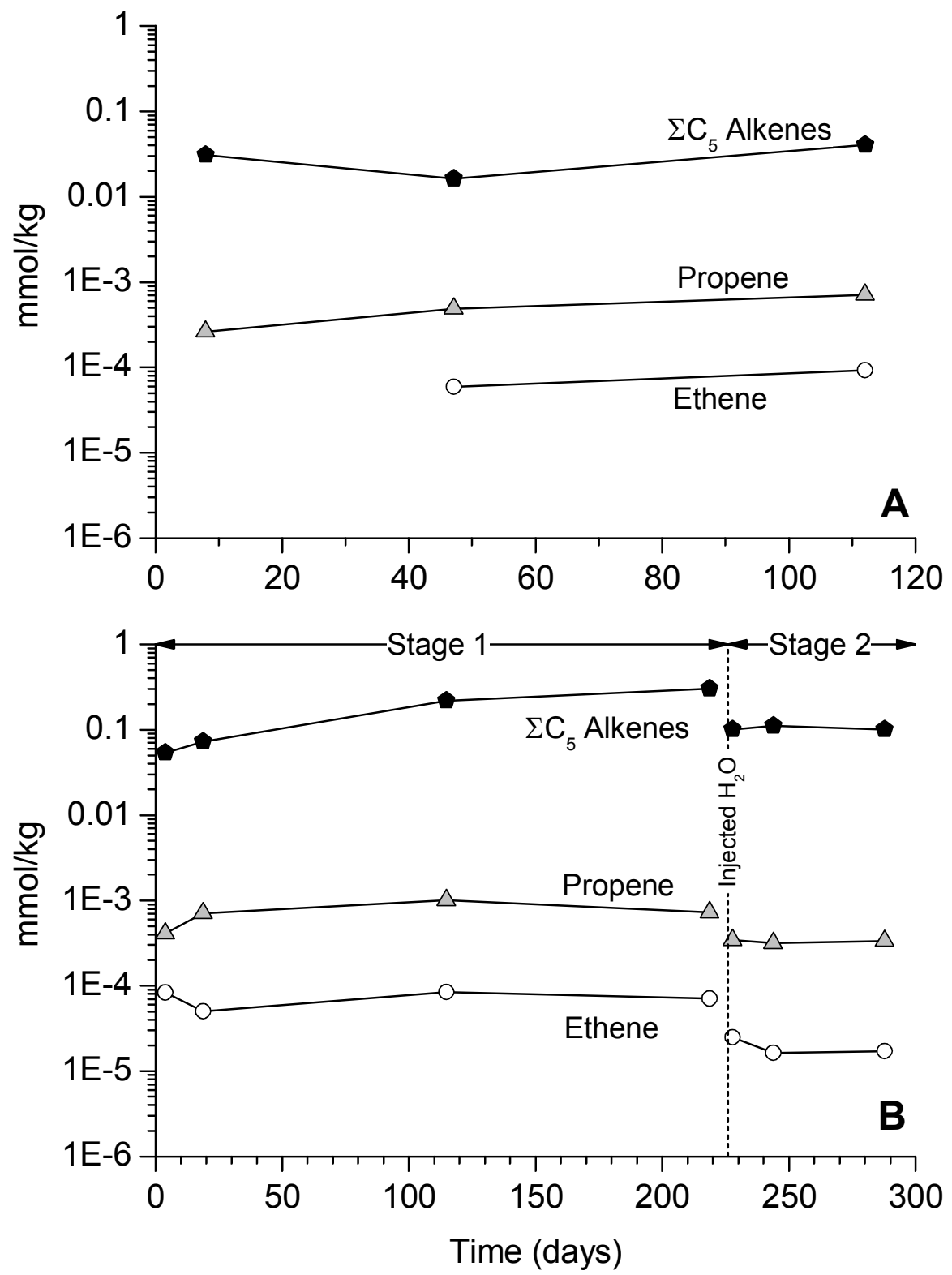

Figure 4.4. Concentrations of $\mathrm{C}_{2}, \mathrm{C}_{3}$ and $\mathrm{C}_{5} n$-alkenes in Experiment 1 (A) and Experiment 2 (B) as a function of time at $323^{\circ} \mathrm{C}$ and $35 \mathrm{MPa}$. The vertical dashed line at 226 days in Experiment 2 represents injection of ${ }^{2} \mathrm{H}$-spiked water. Concentrations of dissolved species were not monitored after 300 days in Experiment 2. 

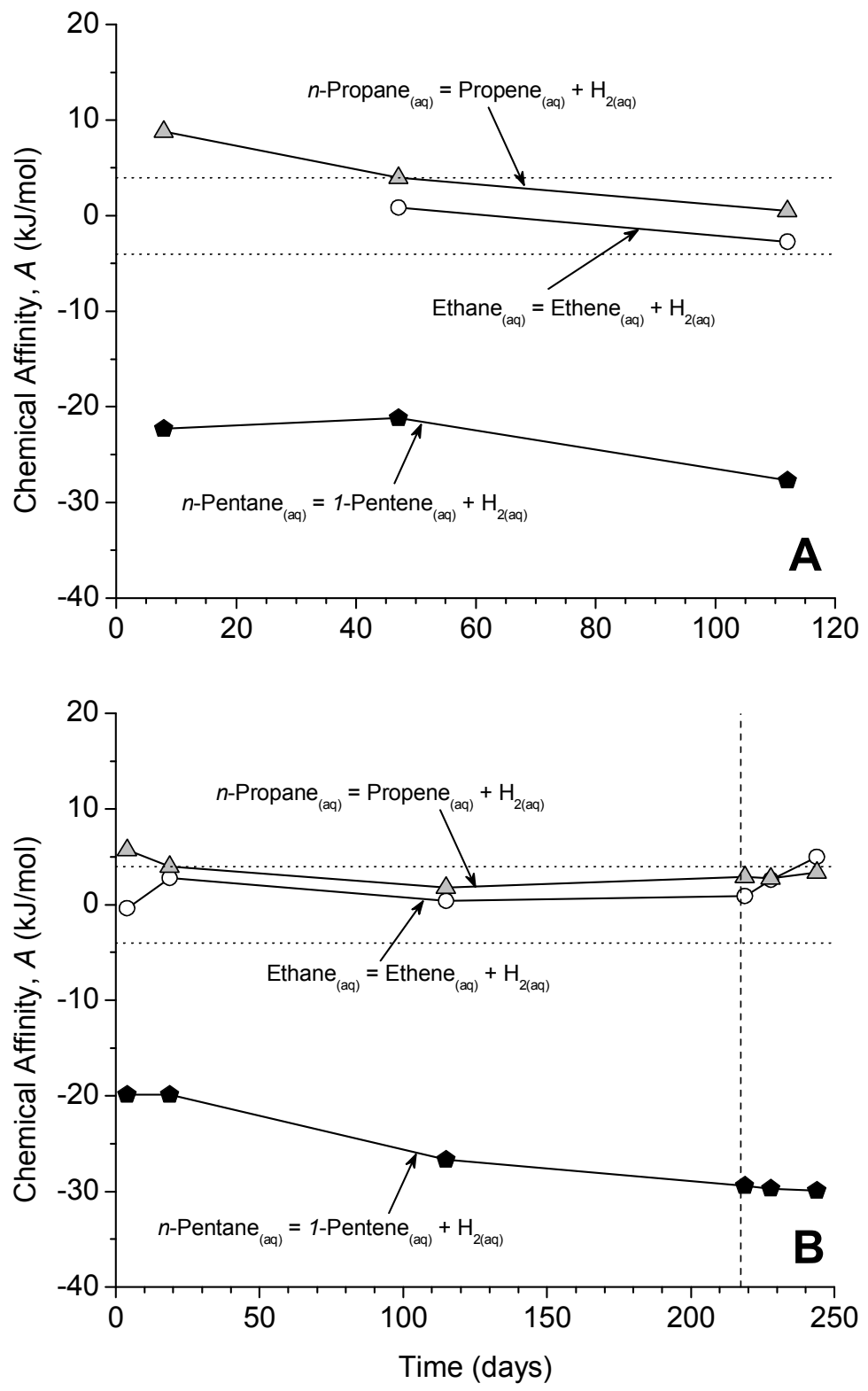

Figure 4.5. Chemical affinities (calculated using equation (6)) for oxidation of $\mathrm{C}_{2}, \mathrm{C}_{3}$ and $\mathrm{C}_{5}$ n-alkanes to their corresponding terminal $n$-alkenes according to reaction (1) as a function of time at $323^{\circ} \mathrm{C}$ and $35 \mathrm{MPa}$ in Experiment 1 (A) and Experiment 2 (B). The vertical dashed line at 226 days in Experiment 2 represents injection of ${ }^{2} \mathrm{H}$-spiked water. Horizontal dotted lines represent the uncertainty associated with attainment of equilibrium $(0 \pm 4 \mathrm{~kJ} / \mathrm{mol}$, SHOCK and HELGESON, 1990). 


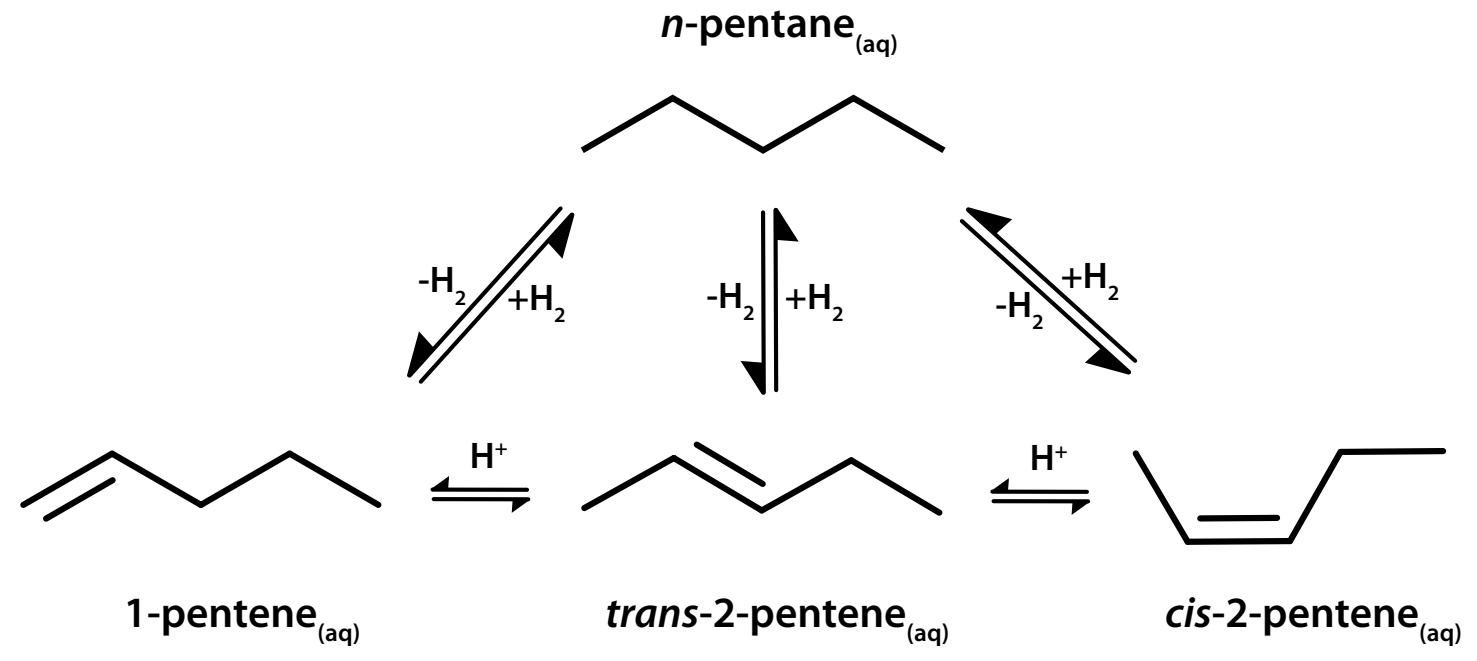

Figure 4.6. Proposed mechanism for the reversible equilibration of $n$-pentane with individual pentene isomers allowing exchange of all $\mathrm{H}$ atoms at each carbon position throughout the molecule. Similar mechanisms could be drawn for other $n$-alkanes with multiple potential alkene isomers. 


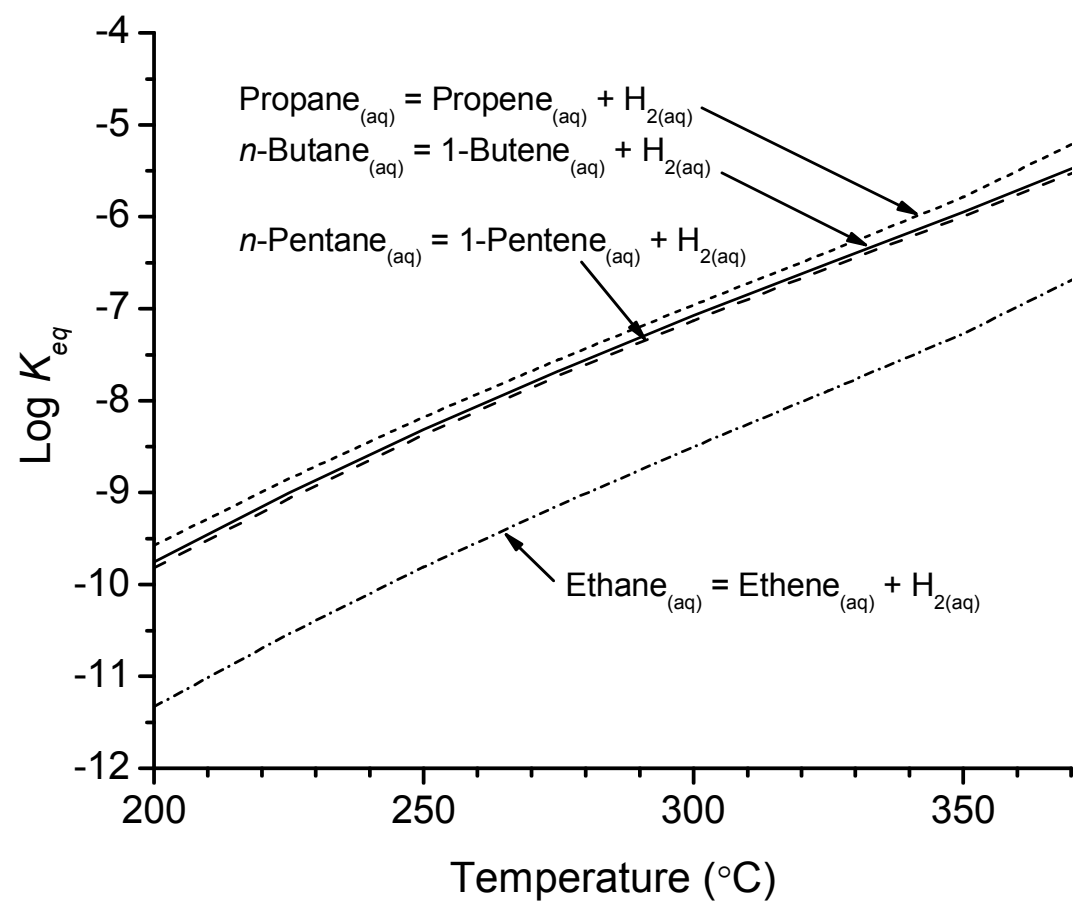

Figure 4.7. Equilibrium constants $\left(K_{e q}\right)$ for reactions between $\mathrm{C}_{2}$ to $\mathrm{C}_{5} n$-alkenes and their corresponding terminal $n$-alkenes as a function of temperature. Requisite data for the construction of this figure are taken from the SUPCRT92 database (JOHNSON et al., 1992) with additional data from SHOCK and HELGESON (1990). 


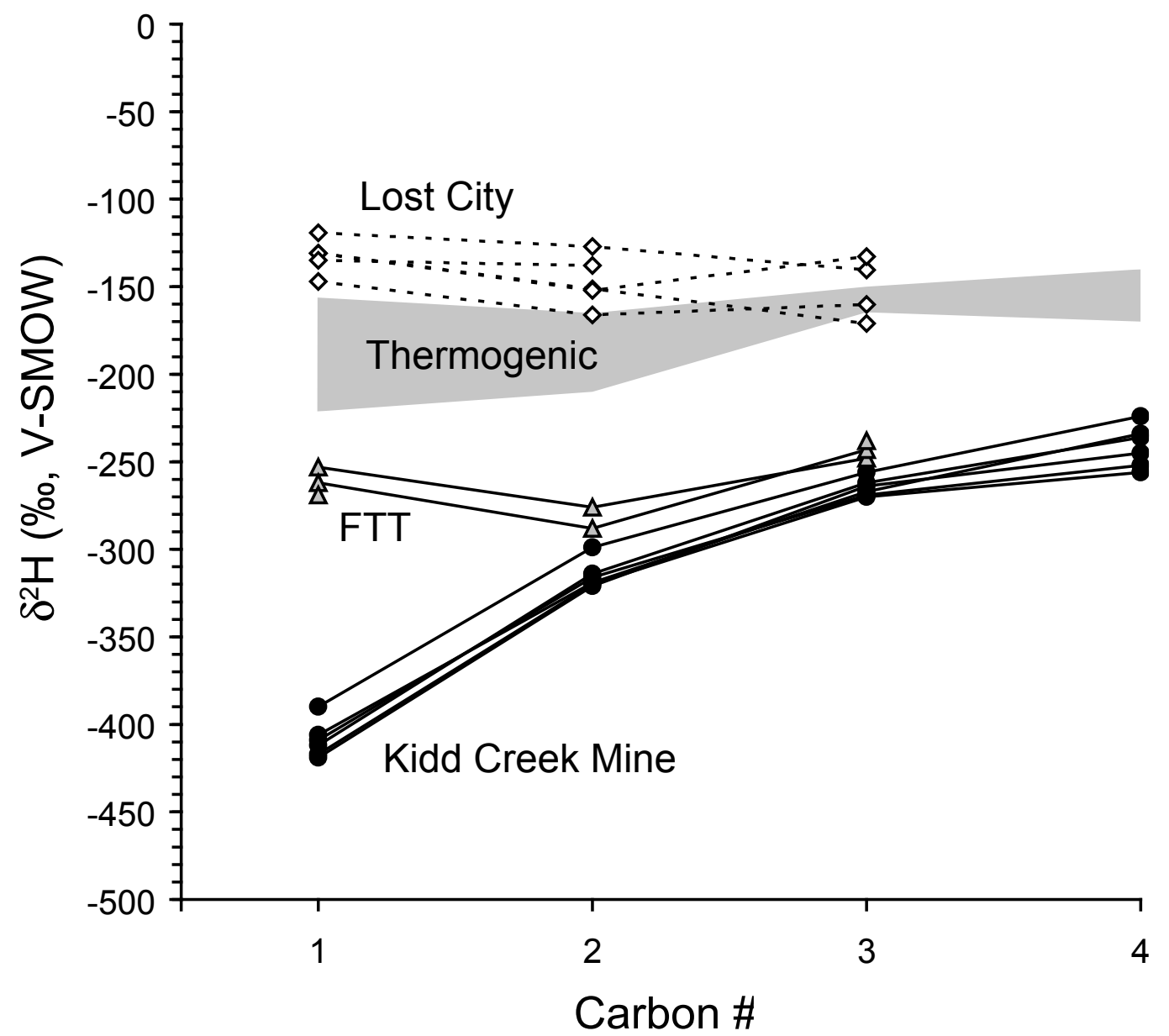

Figure 4.8. Isotopograms showing the $\delta^{2} \mathrm{H}$ values of $n$-alkanes as a function of chain length for the Kidd Creek Mine abiogenic gases (black dots, SHERWOOD LOLLAR et al., 2002), thermogenic gases from Southwest Ontario gas fields (gray area, SHERWOOD LOLLAR et al., 1994, 2002), Lost City vent fluids (open diamonds, PROSKUROWSKI et al., 2008) and alkanes produced by experiment aqueous FischerTropsch-type (FTT) synthesis at $400^{\circ} \mathrm{C}$ (FU et al., 2007). $\delta^{2} \mathrm{H}$ values for $n$-butane were not reported for the latter two studies. 


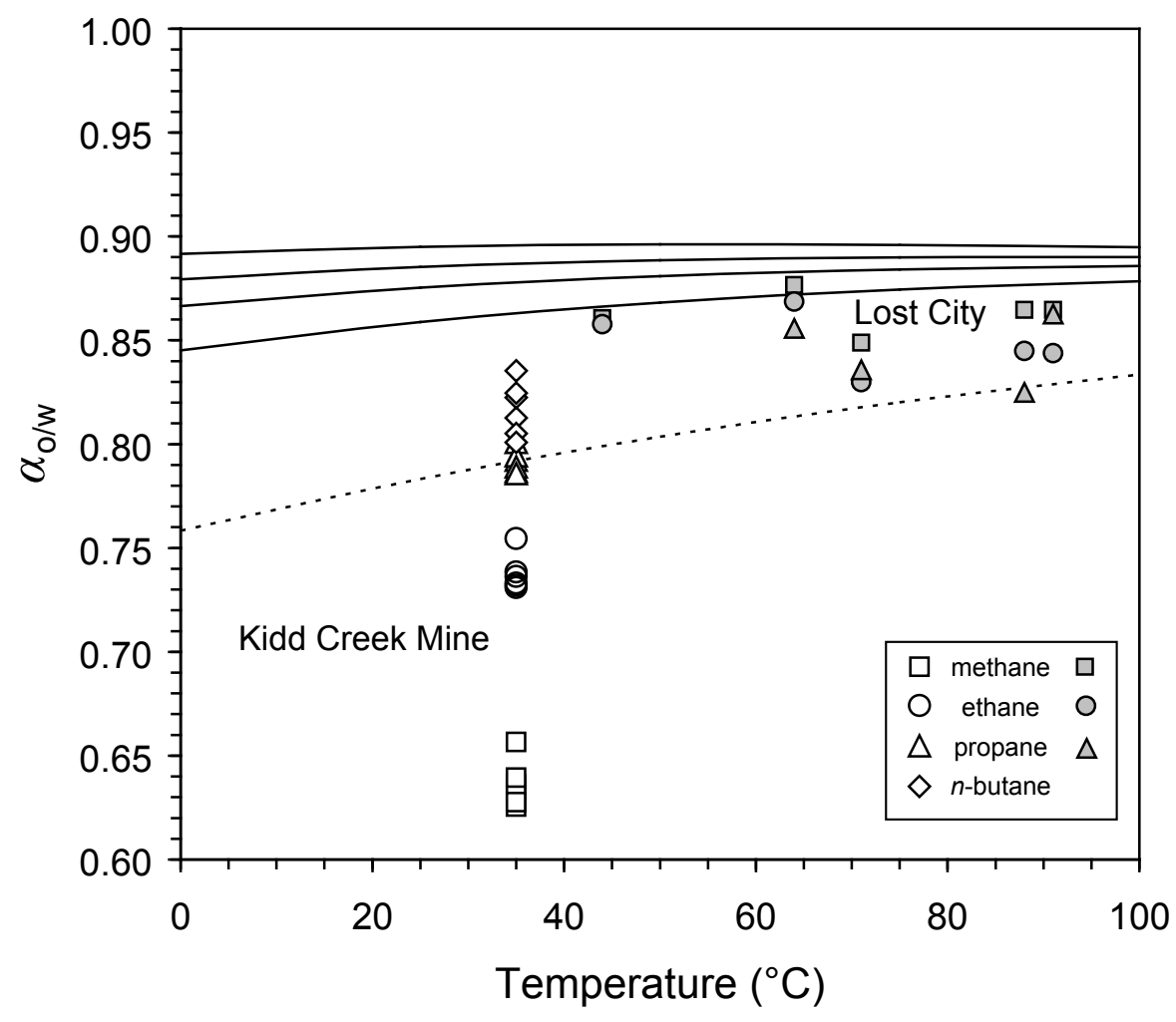

Figure 4.9. Plot of theoretical alkane-water equilibrium fractionation factors for ethane $\left(\alpha_{\text {ethane/w }}\right)$, propane $\left(\alpha_{\text {propane/w }}\right), n$-butane $\left(\alpha_{\text {butane/w }}\right)$ and $n$-pentane $\left(\alpha_{\text {pentane/w }}\right) \mathrm{H}$ calculated as a function of temperature from the data of WANG et al. (2009b). $\alpha_{\text {methane/w }}$ values (dashed line) are calculated as a function of temperature from the data of HoriBE and CRAIG (1995). Also plotted are the apparent $\alpha_{\mathrm{o} / \mathrm{w}}$ values for Kidd Creek Mine (open symbols, SHERWOOD LOLLAR et al., 2002) and Lost City vent fluid (gray symbols, PROSKUROWSKI et al., 2008) $n$-alkanes. For the Kidd Creek Mine gases, fracture waters are of relatively uniform temperature $\left(\sim 35^{\circ} \mathrm{C}\right.$, SHERWOOD LOLLAR et al., 2008) and an average $\delta^{2} \mathrm{H}_{\mathrm{H} 2 \mathrm{O}}$ value of $-71 \%$ is chosen based on the range (-68 to $-74 \%$ ) reported by SHERWOOD et al. (1988). For Lost City, accompanying vent fluid temperatures (PROSKUROWSKI et al., 2008) are plotted and an average $\delta^{2} \mathrm{H}_{\mathrm{H} 2 \mathrm{O}}$ value of $+5 \%$ is chosen based on the range ( +2 to $+7 \%$ ) reported by PROSKUROWSKI et al. (2006). 


\section{REFERENCES}

Abrajano, T. A., Sturchio, N. C., Bohlke, J. K., Lyon, G. L., Poreda, R. J., and Stevens, C. M. (1988) Methane Hydrogen Gas Seeps, Zambales Ophiolite, Philippines - Deep Or Shallow Origin. Chemical Geology 71(1-3), 211-222.

Abrajano, T. A., Sturchio, N. C., Kennedy, B. M., Lyon, G. L., Muehlenbachs, K., and BoHLKE, J. K. (1990) Geochemistry Of Reduced Gas Related To Serpentinization Of The Zambales Ophiolite, Philippines. Applied Geochemistry 5(5-6), 625-630.

ALLEN, D. E. and SEYFRIED, W. E. (2003) Compositional controls on vent fluids from ultramatichosted hydrothermal systems at mid-ocean ridges: An experimental study at $400^{\circ} \mathrm{C}, 500$ bars. Geochimica et Cosmochimica Acta 67(8), 1531-1542.

Allen, D. E. and SEYFrIED, W. E. (2004) Serpentinization and heat generation: Constraints from Lost City and rainbow hydrothermal systems. Geochimica et Cosmochimica Acta 68(6), 1347-1354.

BARKER, J. F. and POLlOCK, S. J. (1984) The geochemistry and origin of natural gases in southern Ontario. Bulletin of Canadian Petroleum Geology 32(3), 313-326.

Bell, J. L. S., PAlmer, D. A., BARnes, H. L., and Drummond, S. E. (1994) ThermalDecomposition Of Acetate: III. Catalysis By Mineral Surfaces. Geochimica et Cosmochimica Acta 58(19), 4155-4177.

Berndt, M. E., Allen, D. E., and SEYfried, W. E. (1996) Reduction of $\mathrm{CO}_{2}$ during serpentinization of olivine at $300{ }^{\circ} \mathrm{C}$ and 500 bar. Geology 24(4), 351-354.

Boreham, C. J., Edwards, D. S., Hope, J. M., Chen, J. H., and Hong, Z. H. (2008) Carbon and hydrogen isotopes of neo-pentane for biodegraded natural gas correlation. Organic Geochemistry 39(10), 1483-1486. 
BuRgOYNE, T. W. and HAYES, J. M. (1998) Quantitative production of $\mathrm{H}_{2}$ by pyrolysis of gas chromatographic effluents. Analytical Chemistry 70(24), 5136-5141.

Charlou, J. L., Donval, J. P., Fouquet, Y., Jean-Baptiste, P., and Holm, N. (2002) Geochemistry of high $\mathrm{H}_{2}$ and $\mathrm{CH}_{4}$ vent fluids issuing from ultramafic rocks at the Rainbow hydrothermal field (36 14'N, MAR). Chemical Geology 191(4), 345-359.

Coplen, T. B. (1988) Normalization of Oxygen and Hydrogen Isotope Data. Chemical Geology 72(4), 293-297.

CRUSE, A. M. and SEEWALD, J. S. (2006) Geochemistry of low-molecular weight hydrocarbons in hydrothermal fluids from Middle Valley, northern Juan de Fuca Ridge. Geochimica et Cosmochimica Acta 70(8), 2073-2092.

Edwards, D. S., Boreham, C. J., Hope, J. M., Preston, J. C., Lepoidevin, S., Buckler, T., and HoNG, Z. (2007) Molecular and stable isotope (D/H AND $\left.{ }^{13} \mathrm{C} /{ }^{12} \mathrm{C}\right)$ compositions of natural gas from the Exmouth Plateau and Rankin Platform, Carnarvon Basin, Australia. In: The 23rd International Meeting on Organic Geochemistry, Torquay, England, 9th14th September 2007. Book of Abstracts, pp. 335-336.

EGLinton, T. I. and EGLINTON, G. (2008) Molecular proxies for paleoclimatology. Earth And Planetary Science Letters 275(1-2), 1-16.

FISHER, A. T. (2003) Geophysical constraints on hydrothermal circulation: observations and models. In: Dahlem Workshop Report: Energy and Mass Transfer in Marine Hydrothermal Systems, (Ed: P. E. Halbach, V. Tunnicliffe, and J. R. Hein), 89, Dahlem University Press. pp. 29-52.

Foustoukos, D. I., SAVOV, I. P., and JANECKY, D. R. (2008) Chemical and isotopic constraints on water/rock interactions at the Lost City hydrothermal field, $30^{\circ} \mathrm{N}$ Mid-Atlantic Ridge. Geochimica et Cosmochimica Acta 72(22), 5457-5474. 
Fu, Q., Sherwood Lollar, B., Horita, J., LaCrampe-Couloume, G., and Seyfried, W. (2007) Abiotic formation of hydrocarbons under hydrothermal conditions: Constraints from chemical and isotopic data. Geochimica et Cosmochimica Acta 71(8), 1982-1998.

Hagemann, R., NiEf, G., and Roth, E. (1970) Absolute isotopic scale for deuterium analysis of natural waters: absolute D/H ratio for SMOW. Tellus 22(6), 712-715.

HARTSHORN, S. R. and SHINER, V. J. (1972) Calculation of H/D, ${ }^{12} \mathrm{C} /{ }^{13} \mathrm{C}$, and ${ }^{12} \mathrm{C} /{ }^{14} \mathrm{C}$ fractionation factors from valence force fields derived for a series of simple organic molecules. Journal of the American Chemical Society 94(26), 9002-9012.

Hilkert, A. W., Douthitt, C. B., Schluter, H. J., and Brand, W. A. (1999) Isotope ratio monitoring gas chromatography mass spectrometry of $\mathrm{D} / \mathrm{H}$ by high temperature conversion isotope ratio mass spectrometry. Rapid Communications In Mass Spectrometry 13(13), 1226-1230.

HoERING, T. C. (1984) Thermal reactions of kerogen with added water, heavy water and pure organic substances. Organic Geochemistry 5(4), 267-278.

Holm, N. G. and CHARLOU, J. L. (2001) Initial indications of abiotic formation of hydrocarbons in the Rainbow ultramafic hydrothermal system, Mid-Atlantic Ridge. Earth And Planetary Science Letters 191(1-2), 1-8.

HoriBE, Y. and CRAIG, H. (1995) D/H fractionation in the system methane-hydrogen-water. Geochimica et Cosmochimica Acta 59(24), 5209-5217.

Hunt, J. M. (1996) Petroleum Geochemistry and Geology. 2nd Ed. W.H. Freeman and Company. Johnson, J. W., OELKERS, E. H., and HELGESON, H. C. (1992) SUPCRT92 - A software package for calculating the standard molal thermodynamic properties of minerals, gases, aqueous species, and reactions from 1 to 5000 bar and 0 to $1000^{\circ} \mathrm{C}$. Computers \& Geosciences 18(7), 899-947. 
KADKO, D. (1996) Radioisotopic studies of submarine hydrothermal vents. Reviews Of Geophysics 34(3), 349-366.

KADKO, D. and BUTTERFIELD, D. A. (1998) The relationship of hydrothermal fluid composition and crustal residence time to maturity of vent fields on the Juan de Fuca Ridge. Geochimica et Cosmochimica Acta 62(9), 1521-1533.

KHARAKA, Y. K. and CAROTHERS, W. W. (1986) Oxygen and Hydrogen Isotope Geochemistry of Deep Basin Brines. In: Handbook of Environmental Isotope Geochemistry: Volume 2 The Terrestrial Environment, B, (Ed: P. Fritz and J. C. Contes), Elsevier. pp. 305-360.

Kharaka, Y. K., CARothers, W. W., and Rosenbauer, R. J. (1983) Thermal Decarboxylation of Acetic Acid - Implications for Origin of Natural Gas. Geochimica et Cosmochimica Acta 47(3), 397-402.

KnyazeV, D. A., Myasoedov, N.F., BochareV, A.V. (1992) The theory of the equilibrium isotope effects of hydrogen. Russian Chemical Reviews 61, 204-220.

Konn, C., Charlou, J. L., Donval, J. P., Holm, N. G., Dehairs, F., and Bouillon, S. (2009) Hydrocarbons and oxidized organic compounds in hydrothermal fluids from Rainbow and Lost City ultramafic-hosted vents. Chemical Geology 258(3-4), 299.

LEIF, R. N. and SimONEIT, B. R. T. (1995) Ketones in hydrothermal petroleums and sediment extracts from Guaymas Basin, Gulf of California. Organic Geochemistry 23(10), 889-904.

LEIF, R. N. and SimONEIT, B. R. T. (2000) The role of alkenes produced during hydrous pyrolysis of a shale. Organic Geochemistry 31(11), 1189-1208.

LEWAN, M. D. (1997) Experiments on the role of water in petroleum formation. Geochimica et Cosmochimica Acta 61(17), 3691-3723.

LEWAN, M. D., WinTERS, J. C., and MCDONALD, J. H. (1979) Generation of oil-like pyrolyzates from organic-rich shales. Science 203(4383), 897-899. 
Lin, L. H., Wang, P. L., Rumble, D., Lippmann-Pipke, J., Boice, E., Pratt, L. M., Lollar, B. S., Brodie, E. L., Hazen, T. C., Andersen, G. L. et al. (2006) Long-term sustainability of a high-energy, low-diversity crustal biome. Science 314(5798), 479-482.

Lippmann, J., Stute, M., Torgersen, T., Moser, D. P., Hall, J. A., Lin, L., Borcsik, M., Bellamy, R. E. S., and OnStotT, T. C. (2003) Dating ultra-deep mine waters with noble gases and Cl-36, Witwatersrand Basin, South Africa. Geochimica et Cosmochimica Acta 67(23), 4597-4619.

MCCollom, T. M. and SEEwALD, J. S. (2001) A reassessment of the potential for reduction of dissolved $\mathrm{CO} 2$ to hydrocarbons during serpentinization of olivine. Geochimica et Cosmochimica Acta 65(21), 3769-3778.

McCollom, T. M. and SEewald, J. S. (2003a) Experimental constraints on the hydrothermal reactivity of organic acids and acid anions: I. Formic acid and formate. Geochimica et Cosmochimica Acta 67(19), 3625-3644.

MCCollom, T. M. and SeEWALd, J. S. (2003b) Experimental study of the hydrothermal reactivity of organic acids and acid anions: II. Acetic acid, acetate, and valeric acid. Geochimica et Cosmochimica Acta 67(19), 3645-3664.

McCollom, T. M. and SEEWALD, J. S. (2007) Abiotic synthesis of organic compounds in deepsea hydrothermal environments. Chemical Reviews 107, 382-401.

NuRMi, P. A., KUKKONEN, I. T., and LAHERMO, P. W. (1988) Geochemistry and origin of saline groundwaters in the Fennoscandian Shield. Applied Geochemistry 3, 185-230.

Onstott, T. C., Lin, L. H., Davidson, M., Mislowack, B., Borcsik, M., Hall, J., Slater, G., WARD, J., LOLLAR, B. S., LiPPMANN-PIPKE, J. et al. (2006) The origin and age of biogeochemical trends in deep fracture water of the Witwatersrand Basin, South Africa. Geomicrobiology Journal 23(6), 369-414. 
Oremland, R. S., Miller, L. G., and Whiticar, M. J. (1987) Sources And Flux Of Natural Gases From Mono Lake, California. Geochimica et Cosmochimica Acta 51(11), 29152929.

PAlmer, D. A. and Drummond, S. E. (1986) Thermal decarboxylation of acetate. Part I. The kinetics and mechanism of reaction in aqueous solution. Geochimica et Cosmochimica Acta 50(5), 813-823.

Proskurowski, G., Lilley, M. D., Kelley, D. S., and Olson, E. J. (2006) Low temperature volatile production at the Lost City Hydrothermal Field, evidence from a hydrogen stable isotope geothermometer. Chemical Geology 229(4), 331-343.

Proskurowski, G., Lilley, M. D., SeEwald, J. S., Fruh-Green, G. L., Olson, E. J., LuPton, J. E., SYLVA, S. P., and KELLEY, D. S. (2008) Abiogenic hydrocarbon production at Lost City hydrothermal field. Science 319(5863), 604-607.

RoBerts, I. and UREY, H. C. (1939) Kinetics of exchange of Oxygen between Benzoic Acid and Water. Journal of the American Chemical Society 61, 2580-2584.

SACHSE, D., RADKE, J., and GLEIXNER, G. (2006) $\delta$ D values of individual n-alkanes from terrestrial plants along a climatic gradient - Implications for the sedimentary biomarker record. Organic Geochemistry 37(4), 469-483.

SACKETT, W. M. (1978) Carbon and hydrogen isotope effects during thermo-catalytic production of hydrocarbons in laboratory simulation experiments. Geochimica et Cosmochimica Acta 42(6), 571-580.

SCHEFuss, E., SCHOUten, S., and SchNEIDER, R. R. (2005) Climatic controls on central African hydrology during the past 20,000 years. Nature 437(7061), 1003-1006. 
SChimmelmanN, A., LEWAN, M. D., and WINTSCH, R. P. (1999) D/H isotope ratios of kerogen, bitumen, oil, and water in hydrous pyrolysis of source rocks containing kerogen types I, II, IIS, and III. Geochimica et Cosmochimica Acta 63(22), 3751-3766.

Schimmelmann, A., Sessions, A. L., and Mastalerz, M. (2006) Hydrogen isotopic (D/H) composition of organic matter during diagenesis and thermal maturation. Annual Review Of Earth And Planetary Sciences 34, 501-533.

Schimmelmann, A., Boudou, J. P., LeWAN, M. D., and WinTSCH, R. P. (2001) Experimental controls on $\mathrm{D} / \mathrm{H}$ and ${ }^{13} \mathrm{C} /{ }^{12} \mathrm{C}$ ratios of kerogen, bitumen and oil during hydrous pyrolysis. Organic Geochemistry 32(8), 1009-1018.

Schimmelmann, A., Sessions, A. L., Boreham, C. J., Edwards, D. S., Logan, G. A., and Summons, R. E. (2004) D/H ratios in terrestrially sourced petroleum systems. Organic Geochemistry 35(10), 1169-1195.

SCHMidt, K., Koschinsky, A., GARBe-SchonberG, D., De CARVAlHO, L. M., and Seifert, R. (2007) Geochemistry of hydrothermal fluids from the ultramafic-hosted Logatchev hydrothermal field, $15^{\circ} \mathrm{N}$ on the Mid-Atlantic Ridge: Temporal and spatial investigation. Chemical Geology 242(1-2), 1-21.

SCHOELL, M. (1983) Genetic Characterization of Natural Gases. AAPG Bulletin 67(3), 546-546.

SEEWALD, J. (1997) Mineral redox buffers and the stability of organic compounds under hydrothermal conditions. Mat. Res. Soc. Symp. Proc. 412, 317-331.

SEEWALD, J. S. (1994) Evidence For Metastable Equilibrium Between Hydrocarbons Under Hydrothermal Conditions. Nature 370(6487), 285-287.

SEEWALD, J. S. (2001) Model for the origin of carboxylic acids in basinal brines. Geochimica et Cosmochimica Acta 65(21), 3779-3789. 
SEEWALD, J. S. (2001) Aqueous geochemistry of low molecular weight hydrocarbons at elevated temperatures and pressures: Constraints from mineral buffered laboratory experiments. Geochimica et Cosmochimica Acta 65(10), 1641-1664.

SEEWALD, J. S. (2003) Organic-inorganic interactions in petroleum-producing sedimentary basins. Nature 426(6964), 327-333.

SEewald, J. S., Zolotov, M. Y., and McCollom, T. (2006) Experimental investigation of single carbon compounds under hydrothermal conditions. Geochimica et Cosmochimica Acta 70(2), 446-460.

SESSIONS, A. L. (2006) Isotope-ratio detection for gas chromatography. Journal Of Separation Science 29(12), 1946-1961.

SESSIONS, A. L., Sylva, S. P., SummOnS, R. E., and HAYES, J. M. (2004) Isotopic exchange of carbon-bound hydrogen over geologic timescales. Geochimica et Cosmochimica Acta 68(7), 1545-1559.

SEYFried, W., Foustoukos, D. I., and ALLEN, D. E. (2004) Ultramafic-hosted hydrothermal systems at Mid-Ocean Ridges: Chemical and physical constraints on $\mathrm{pH}$, redox, and carbon reduction reactions. In: Mid-Ocean Ridges: Hydrothermal Interactions between the Lithosphere and Oceans, (Ed: C. German, J. Lin, and L. Parson), AGU Monograph, 148, American Geophysical Union. pp. 267-285.

SEYFRIED, W., D.R. JANECKY AND M.E. BERNDT (1987) Rocking autoclaves for hydrothermal experiments II: The flexible reaction-cell system. In: Hydrothermal Experimental Techniques, (Ed: G. C. Ulmer and H. L. Barnes), Wiley. pp. 216-239.

SEYFRIED, W. E. and DING, K. (1995) Phase equilibria in subseafloor hydrothermal systems: a review of the role of redox, temperature, $\mathrm{pH}$ and dissolved $\mathrm{Cl}$ on the chemistry of hot spring fluids at mid-ocean ridges. In: Seafloor Hydrothermal Systems: Physical, 
Chemical, Biological, and Geological Interactions, (Ed: S. E. Humphris, R. A.

Zierenberg, L. S. Mullineaux, and R. E. Thomson), AGU Monograph, 91, American Geophysical Union. pp. 248-272.

Sherwood, B., Fritz, P., Frape, S. K., MAcko, S. A., Weise, S. M., and Welhan, J. A. (1988)

Methane Occurrences In The Canadian Shield. Chemical Geology 71(1-3), 223-236.

Sherwood Lollar, B., Frape, S. K., Weise, S. M., Fritz, P., Macko, S. A., and Welhan, J. A. (1993a) Abiogenic Methanogenesis In Crystalline Rocks. Geochimica et Cosmochimica Acta 57(23-24), 5087-5097.

Sherwood Lollar, B., Frape, S. K., Fritz, P., Macko, S. A., Welhan, J. A., BlomQvist, R., and LAHERMO, P. W. (1993b) Evidence For Bacterially Generated Hydrocarbon-Gas In Canadian Shield And Fennoscandian Shield Rocks. Geochimica et Cosmochimica Acta 57(23-24), 5073-5085.

SHerwood Lollar, B., Weise, S. M., FraPe, S. K., and BARKer, J. F. (1994) Isotopic constraints on the migration of hydrocarbon and helium gases of southwestern Ontario. Bulletin of Canadian Petroleum Geology 42(3), 283-295.

Sherwood Lollar, B., Westgate, T. D., WArd, J. A., Slater, G. F., and LacrampeCouloume, G. (2002) Abiogenic formation of alkanes in the Earth's crust as a minor source for global hydrocarbon reservoirs. Nature 416(6880), 522-524.

Sherwood Lollar, B., Lacrampe-Couloume, G., Slater, G. F., WArd, J., Moser, D. P., GiHRING, T. M., LIN, L. H., and OnSTOTT, T. C. (2006) Unravelling abiogenic and biogenic sources of methane in the Earth's deep subsurface. Chemical Geology 226(3-4), 328-339.

Sherwood Lollar, B., LACrAmpe-Couloume, G., Voglesonger, K., Onstott, T. C., PRATT, L. M., and Slater, G. F. (2008) Isotopic signatures of $\mathrm{CH}_{4}$ and higher 
hydrocarbon gases from Precambrian Shield sites: A model for abiogenic polymerization of hydrocarbons. Geochimica et Cosmochimica Acta 72(19), 4778-4795.

SHOCK, E. L. (1992) Chemical Environments Of Submarine Hydrothermal Systems. Origins Of Life And Evolution Of The Biosphere 22(1-4), 67-107.

SHOCK, E. L. and Helgeson, H. C. (1990) Calculation of the thermodynamic and transport properties of aqueous species at high pressures and temperatures: Standard partial molal properties of organic species. Geochimica et Cosmochimica Acta 54(4), 915-945.

Siskin, M., Brons, G., KATRitzky, A. R., and BAlasubramanian, M. (1990) Aqueous Organic Chemistry.1. Aquathermolysis - Comparison with Thermolysis in the Reactivity of Aliphatic Compounds. Energy \& Fuels 4(5), 475-482.

Surdam, R. C. and CRossey, L. J. (1985) Organic Inorganic Reactions During Progressive Burial - Key To Porosity And Permeability Enhancement And Preservation. Philosophical Transactions Of The Royal Society Of London Series A-Mathematical Physical And Engineering Sciences 315(1531), 135-156.

SURDAM, R. C., JiAO, Z. S., and MACGOWAN, D. B. (1993) Redox Reactions Involving Hydrocarbons And Mineral Oxidants - A Mechanism For Significant Porosity Enhancement In Sandstones. AAPG Bulletin 77(9), 1509-1518.

TANG, Y. C., ELLIS, G. S., and MA, Q. S. (2007) Use of carbon and hydrogen stable isotopic composition to quantitatively assess natural gas generation. Geochimica et Cosmochimica Acta 71(15), A1001-A1001.

Tang, Y. C., Huang, Y. S., Ellis, G. S., Wang, Y., Kralert, P. G., Gillaizeau, B., Ma, Q. S., and HWANG, R. (2005) A kinetic model for thermally induced hydrogen and carbon isotope fractionation of individual n-alkanes in crude oil. Geochimica et Cosmochimica Acta 69(18), 4505-4520. 
Tissot, B. P. and Welte, D. H. (1984) Petroleum Formation and Occurrence. 2nd Ed. SpringerVerlag.

TOBIAS, H. J. and BRENNA, J. T. (1997) On-line pyrolysis as a limitless reduction source for highprecision isotopic analysis of organic-derived hydrogen. Analytical Chemistry 69(16), $3148-3152$.

TOULMIn, P., III and BARTON, P. B., JR. (1964) A thermodynamic study of pyrite and pyrrhotite. Geochimica et Cosmochimica Acta 28, 641-671.

WAng, Y. and Sessions, A. L. (2008) Memory Effects in Compound-Specific D/H Analysis by Gas Chromatography/Pyrolysis/Isotope-Ratio Mass Spectrometry. Analytical Chemistry 80(23), 9162-9170.

WANG, Y., SEssions, A., NIELSEN, R. J., and GODDARD, W. A., III (2009a) Equilibrium ${ }^{2} \mathrm{H} /{ }^{1} \mathrm{H}$ fractionations in organic molecules: I. Experimental calibration of ab initio calculations. Geochimica et Cosmochimica Acta 73(23), 7060-7075.

WAng, Y., Sessions, A., Nielsen, R. J., and GodDARD, W. A., III (2009b) Equilibrium ${ }^{2} \mathrm{H} /{ }^{1} \mathrm{H}$ fractionations in organic molecules. II: Linear alkanes, alkenes, ketones, carboxylic acids, esters, alcohols and ethers. Geochimica et Cosmochimica Acta 73(23), 7076-7086.

Ward, J. A., Slater, G. F., Moser, D. P., Lin, L. H., LaCramPe-Couloume, G., Bonin, A. S., Davidson, M., Hall, J. A., Mislowack, B., Bellamy, R. E. S. et al. (2004) Microbial hydrocarbon gases in the Witwatersrand Basin, South Africa: Implications for the deep biosphere. Geochimica et Cosmochimica Acta 68(15), 3239-3250.

Weres, O., Newton, A. S., and TsaO, L. (1988) Hydrous Pyrolysis of Alkanes, Alkenes, Alcohols and Ethers. Organic Geochemistry 12(5), 433-444.

WhiticAR, M. J., FABER, E., and SCHOELl, M. (1985) Hydrogen and Carbon Isotopes of $C_{1}$ To $\mathrm{C}_{5}$ Alkanes in Natural Gases. AAPG Bulletin 69(2), 316 (abstr.). 


\title{
CHAPTER 5
}

\section{Geochemistry of hydrothermal fluids from the PACMANUS, Northeast Pual and Vienna Woods vent fields, Manus Basin, Papua New Guinea}

(A modified version of this Chapter has been submitted to Geochimica et Cosmochimica Acta, December $11^{\text {th }}, 2009$, and is currently under review as a coauthored paper with Jeffrey S. Seewald, Peter Saccocia, Emily Walsh, Wolfgang Bach, Paul Craddock, Wayne C. Shanks, Sean Sylva, Thomas Pichler, Martin Rosner)

\begin{abstract}
Processes controlling the composition of seafloor hydrothermal fluids in silicic backarc/near-arc crustal settings remain poorly constrained despite growing evidence for extensive magmatic-hydrothermal activity in such environments. In order to assess the effects of water-rock interaction with varying substrate compositions and magmatic fluid degassing on hydrothermal fluid chemistry, we conducted a survey of vent fluid compositions from two contrasting regions of the Manus backarc basin, Papua New Guinea - the felsic-hosted PACMANUS and nearby Northeast (NE) Pual hydrothermal vent fields (located on Pual Ridge near the active New Britain Arc) and the more arc-distal basalt-hosted Vienna Woods field. In 2006, fluid samples were collected from 18 discrete vents at PACMANUS/NE Pual and 3 at Vienna Woods using both gas-tight and syringe-style samplers. High temperature fluids at
\end{abstract}


Vienna Woods were characterized by uniform endmember temperatures $\left(273-285^{\circ} \mathrm{C}\right)$ and major element compositions, low dissolved $\mathrm{CO}_{2}$ concentrations $(4.4 \mathrm{mmol} / \mathrm{kg})$ and high measured $\mathrm{pH}$ $\left(4.2-4.9\right.$ at $\left.25^{\circ} \mathrm{C}\right)$. Temperatures and compositions were highly variable at PACMANUS and a large, newly discovered vent area (Fenway) was observed to be vigorously venting boiling $\left(358^{\circ} \mathrm{C}\right)$ fluid. All PACMANUS/NE Pual fluids are characterized by negative $\delta \mathrm{D}_{\mathrm{H} 2 \mathrm{O}}$ values, in contrast to positive values at Vienna Woods, suggesting substantial magmatic water input to circulating fluids at the former. Low measured $\mathrm{pH}\left(25^{\circ} \mathrm{C}\right)$ values $(\sim 2.6$ to 2.7$)$, high endmember $\mathrm{CO}_{2}$ (up to $272 \mathrm{mmol} / \mathrm{kg}$ ) and negative $\delta^{34} \mathrm{~S}_{\mathrm{H} 2 \mathrm{~S}}$ values (down to $-2.7 \%$ ) in some vent fluids are also consistent with degassing of acid-volatile species from evolved magma. Dissolved $\mathrm{CO}_{2}$ at PACMANUS is enriched in ${ }^{13} \mathrm{C}(-4.1 \%$ o to $-2.3 \%$ ) relative to Vienna Woods $(-5.2 \%$ to $-5.7 \%$ o $)$ suggesting a contribution of slab-derived carbon to the former. The mobile elements (e.g. Li, K, $\mathrm{Rb}, \mathrm{Cs}$ and $\mathrm{B}$ ) are also greatly enriched in PACMANUS and NE Pual fluids reflecting increased abundances in the crust there relative to the Vienna Woods field. Variations in alkali and dissolved gas abundances with $\mathrm{Cl}$ at PACMANUS and NE Pual suggest that phase separation has affected fluid chemistry despite the low temperatures of many vents. These fluids further differ from those at Vienna Woods in that substantial modification has taken place as a result of seawater entrainment. Almost all PACMANUS and NE Pual samples have consistently high measured Mg concentrations, indicating subsurface seawater entrainment is pervasive there. Trends of increasingly non-conservative $\mathrm{SO}_{4}$ behavior, decreasing endmember $\mathrm{Ca} / \mathrm{Cl}$ and $\mathrm{Sr} / \mathrm{Cl}$ ratios with increased $\mathrm{Mg}$ indicate extensive subsurface anhydrite deposition is occurring. Decreased $\mathrm{pH}$ and endmember $\mathrm{Fe} / \mathrm{Mn}$ ratios in higher $\mathrm{Mg}$ fluids indicate that sulfide deposition is also occurring as a result of mixing/cooling and leading to secondary acidity production. Several low temperature $\left(\leq 80^{\circ} \mathrm{C}\right)$ fluids at PACMANUS and NE Pual also show evidence for anhydrite dissolution and water-rock interaction (B fixation) subsequent to seawater entrainment. This 
study demonstrates that arc proximity has the potential to profoundly influence vent fluid compositions in back-arc settings and provides useful insights into hydrothermal processes occurring there. 


\section{INTRODUCTION}

Hydrothermal activity in back-arc basins shares many common physical and chemical processes with mid-ocean ridge (MOR) settings, including water-rock reaction, magmatic volatile degassing, phase separation and subsurface fluid mixing. In back-arc hydrothermal systems, however, the proximity to a subduction zone and eruption of magmas with higher water contents relative to mid-ocean ridge basalt (MORB) results in a broader range of degassed volatiles capable of influencing vent fluid chemistry (de Ronde, 1995; Ishibashi and Urabe, 1995; Yang and Scott, 2006). In contrast to MOR settings, where $\mathrm{CO}_{2}$ is the dominant volatile degassed, the exsolution of large quantities of $\mathrm{H}_{2} \mathrm{O}$ and $\mathrm{CO}_{2}$ from water-rich silicic magmas can be accompanied by acid-volatile species such as $\mathrm{SO}_{2}, \mathrm{HCl}$ and $\mathrm{HF}$. Subsequent entrainment of water-rich magmatic fluids into existing hydrothermal circulation cells could substantially lower $\mathrm{pH}$, thereby influencing the transport of dissolved metals and styles of crustal alteration (Gamo et al., 1997; Gena et al., 2001; Gamo et al., 2006; Yang and Scott, 2006). Moreover, magmatic fluids have long been proposed as an additional source of economically important metals (i.e. $\mathrm{Cu}$, $\mathrm{Zn}, \mathrm{Ag}$ and $\mathrm{Au}$ ) in excess of that feasible by rock leaching alone (Yang and Scott, 1996; Sun et al., 2004; Simmons and Brown, 2006; Yang and Scott, 2006). Many large volcanic-hosted massive sulfide deposits (Kuroko-type) are thought to have formed in arc and back-arc magmatichydrothermal settings (Franklin et al., 1981; Herzig and Hannington, 1995). Thus, models for the formation of metal sulfide deposits in back-arc environments require an understanding of the role of magmatic fluids in metal transport and deposition.

Discharge of magmatic fluids directly into the water column has been observed above submarine arc volcanoes (Embley et al., 2006; Nakagawa et al., 2006; Lupton et al., 2008) and seamounts (Cheminée et al., 1991; Gamo et al., 1993; de Ronde et al., 2005; Resing et al., 2007), and contributions of magmatic acid-volatile species and water to hydrothermal fluids have been 
reported in a few locations (Sedwick et al., 1992; McMurtry et al., 1993; Gamo et al., 1997; Zengqian et al., 2005; Nakagawa et al., 2006). In general, however, active magmatichydrothermal systems hosted in felsic crust have been historically under-sampled despite the prevalence of hydrothermal activity associated with back-arc volcanism in the western Pacific (Ishibashi and Urabe, 1995).

In 1999 the Ocean Drilling Program (ODP) drilled into an active felsic-hosted hydrothermal system at the PACMANUS site in the Eastern Manus Volcanic Zone, Papua New Guinea (Fig. 5.1 and Fig. 5.2). Subsequent investigations of alteration assemblages recovered in drill-cores indicated a complex system affected by both temporally and spatially variable magmatic acid-volatile inputs and subsurface mixing of hydrothermal fluids with seawater (Bach et al., 2003; Roberts et al., 2003; Lackschewitz et al., 2004; Paulick et al., 2004; Paulick and Bach, 2006; Binns et al., 2007). In addition to magmatic inputs, pervasive entrainment and mixing of seawater, as indicated by ODP Leg 193, may be an important process that influences vent fluid chemistry in back-arc hydrothermal systems.

In 2006 we conducted a detailed chemical and isotopic survey of vent fluids at the neararc hydrothermal fields on Pual Ridge (PACMANUS and Northeast (NE) Pual), and the more distal basalt-hosted Vienna Woods field, to examine the effects of substrate composition, magmatic fluid inputs, and subsurface mixing on vent fluid geochemistry. Here, we demonstrate that present hydrothermal activity at Pual Ridge is influenced by variable inputs of acidic magmatic solutions to seawater-derived vent fluids at depth, in addition to processes of water/rock reaction and phase separation. We further show that widespread seawater entrainment prior to venting modifies the composition of resulting mixtures and partially obscures the effects of magmatic fluid inputs. In contrast, the geochemistry of vent fluids at Vienna Woods is similar 
in many respects to other temporally stable hydrothermal systems commonly sampled in MOR settings. 


\section{GeOLOGiCAL SETTing}

The Manus Basin is a young (ca. 3.5Ma old), rapidly opening $(137 \mathrm{~mm} / \mathrm{yr})$ back-arc basin in the northeastern portion of the Bismarck Sea (Fig. 5.1a), tectonically bordered to the north by the presently inactive Manus Trench and to the south by the Willaumez Rise and the active New Britain Trench (Taylor, 1979a; Taylor et al., 1994; Tregoning, 2002; Lee and Ruellan, 2006). Volcanism associated with basin extension occurs along a series of spreading centers and rifts between three major transform faults (Taylor, 1979a; Taylor et al., 1994; Martinez and Taylor, 1996). Approximately $250 \mathrm{~km}$ from the active New Britain Arc in the center of the basin, spreading occurs along the $120 \mathrm{~km}$-long Manus Spreading Center (MSC), bounded by the Willaumez and Djual transform faults (Fig. 5.1a). Predominantly MORB-like basaltic lavas erupt along the MSC (Sinton et al., 2003) and numerous areas of hydrothermal activity have been reported, the largest of which is the unsedimented Vienna Woods field (Both et al., 1986; Tufar, 1990; Lisitsyn et al., 1993). In contrast, the eastern Manus Basin, between the Djual and Weitin transform faults, is an extensional transform zone within remnant Eocene-Oligocene island-arc crust that is thought to have formed during previous southwestward subduction along the Manus Trench (Binns and Scott, 1993; Binns et al., 2007). As such, it is probably the precursor of a back-arc spreading center like the MSC. Volcanism associated with the incipient rifting of existing intermediate/felsic crust has produced a complex series of en echelon neovolcanic ridges (such as Pual Ridge, Fig. 5.1b) and volcanic domes, known as the Eastern Manus Volcanic Zone (EMVZ, Fig. 5.1a), of basaltic to rhyodacitic composition (Binns and Scott, 1993; Kamenetsky et al., 2001; Sinton et al., 2003). These edifices possess isotopic, major and trace element characteristics similar to subaerial volcanoes of the New Britain Arc indicating strong arc affinities (Sinton et al., 2003; Pearce and Stern, 2006). Due to the proximity of the EMVZ to the New Britain Arc $(<100 \mathrm{~km})$, the relative influences of the mantle wedge, subducting slab and 
remnant arc crust on melt production and volcanism are highly complex (Sinton et al., 2003; Pearce and Stern, 2006). Several large areas of hydrothermal activity have been discovered in the EMVZ (Fig. 5.1a) in the last two decades, including the DESMOS caldera (Gamo et al., 1993; Gamo et al., 1997), SuSu Knolls (Binns et al., 1997; Moss and Scott, 2001; Tivey et al., 2006; Hrischeva et al., 2007) and PACMANUS vent fields (Binns and Scott, 1993).

\subsection{Hydrothermal Vent Fields}

\subsubsection{Vienna Woods}

Current hydrothermal activity at the Vienna Woods field (Fig. 5.2a) is confined to an area of approximately $100 \mathrm{~m}$ by $150 \mathrm{~m}$ at a water depth of $2780 \mathrm{~m}$ within the rift zone of the MSC ( $\sim 0.5 \mathrm{~km}$ south of the neo-volcanic zone). Though the site is hosted in basalt that is compositionally similar to MORB, substrate composition along the MSC is variable and more intermediate compositions occur to the south and north of Vienna Woods (Shaw et al., 2004). The rift zone itself is comprised of basaltic pillow lavas/sheet flows with minimal sediment cover and occasional 1-2m wide along-axis fissures. Hydrothermal activity in 2006 consisted of three main clusters of tall (5-12m high) active sulfide structures separated by $100-150 \mathrm{~m}$ and generally aligned along these fissures, in addition to numerous smaller inactive chimneys. All fluids sampled were relatively clear in color with little visible precipitate upon mixing with seawater.

\subsubsection{PACMANUS and Northeast Pual}

The PACMANUS (Papua New Guinea-Australia-Canada-MANUS) vent field, originally discovered during the 1991 expedition of the same name, consists of several discrete vent areas distributed over a 1.5km section of Pual Ridge (Fig. 5.1b, (Binns and Scott, 1993). Pual Ridge is a $20 \mathrm{~km}$ long, Y-shaped neovolcanic edifice located $80 \mathrm{~km}$ from Rabaul Volcano on the New 
Britain Arc (Fig. 5.1b). With a ridge crest at $1600-1700 \mathrm{~m}$ depth, it is $1-1.5 \mathrm{~km}$ in width and stands $\sim 500 \mathrm{~m}$ above the sedimented basaltic to andesitic seafloor of the EMVZ (Binns et al., 2007). Erupted lavas consist of highly vesicular and blocky dacite/rhyodacite with some rhyolite and the ridge itself is constructed of stacked, subhorizontal flows up to $30 \mathrm{~m}$ thick with negligible to minor sediment cover (Binns and Scott, 1993; Paulick et al., 2004; Yang and Scott, 2005). Based on the composition of erupted lavas, Yang and Scott (2002) proposed that the entire ridge represents a single calc-alkaline trend that may have been generated by fractional crystallization of a single volatile-rich mafic magma source. While conclusive evidence for magma bodies beneath Pual Ridge is currently lacking, a faint and discontinuous seismic reflector was observed at $\sim 2 \mathrm{~km}$ depth in 2002 (Lee, 2003; Binns et al., 2007). Based on the $\mathrm{Cl}$ and $\mathrm{H}_{2} \mathrm{O}$ contents of volcanic glasses from Pual Ridge and solubility constraints, Sun et al. (2007) also suggested that a magma chamber might be located near this depth. In contrast to Vienna Woods, meter-scale fissures are noticeably absent on the surface of Pual Ridge.

The five main areas of hydrothermal activity previously visited at PACMANUS include Roman Ruins, Roger's Ruins, Satanic Mills, Snowcap and Tsukushi. These are distributed between two broad highs along the crest of Pual Ridge at depths ranging from $1640 \mathrm{~m}$ to $1710 \mathrm{~m}$ (Fig. 5.1b, Fig. 5.2b and 5.2c). To the north, hydrothermal activity at the Roman Ruins and smaller Roger's Ruins areas in 2006 (Fig. 5.2b) consisted of focused black or gray smoker fluids venting from multi-spired, sulfide chimney complexes up to $10 \mathrm{~m}$ tall. Areas of hydrothermal activity to the south encircle the Snowcap Dome (Fig. 5.2c). Similar styles of venting through smaller sulfide structures were evident at Satanic Mills and diffuse fluid also appeared to be flowing from a nearby depression tentatively identified as the drill hole of ODP Leg 193 Site 1191A (Fig. 5.2c). A $5.3^{\circ} \mathrm{C}$ temperature anomaly (above ambient) was measured $\sim 15 \mathrm{~cm}$ beneath the surface of the drilling mud/bore-hole cuttings, which were covered by a white microbial mat 
(Tivey et al., 2006). At Tsukushi, sulfide structures were found to be largely inactive in 2006 and only a single low temperature fluid $\left(62^{\circ} \mathrm{C}\right)$ exiting from an oxide mound fissure was sampled. The Snowcap vent area is a broad knoll of mostly diffuse venting with a small area of moderate temperature focused venting $\left(<180^{\circ} \mathrm{C}\right)$ confined to the western flank (Fig. 5.2c). In contrast to Roman/Roger's Ruins, Satanic Mills and Tsukushi areas where sulfide structures are located atop rugged surficial lava flows, the Snowcap area is heavily sedimented with hydrothermal precipitate/volcaniclastic debris, and lava outcrops are rare. Several outcrops of heavily bleached rocks cemented with native sulfur were observed near active vents, presumably reflecting advanced argillic alteration by acid-sulfate type fluids (Brimhall and Ghiorso, 1983; Gena et al., 2001; Binns et al., 2007). However, no 'white smoker activity' similar to the DESMOS caldera site (Gamo et al., 1997; Gamo et al., 2006) has been observed anywhere on Pual Ridge. A new site, Fenway, was discovered $\sim 200 \mathrm{~m}$ south of Satanic Mills at $1710 \mathrm{~m}$ depth during this expedition (Fig. 5.2c). The core area of the Fenway site is a $40 \mathrm{~m}$ diameter two-tiered mound composed of chimney debris, massive anhydrite-sulfide breccia and coarse anhydrite sand. At its summit (1710m depth), a large black smoker chimney complex was found to be vigorously venting the highest temperature fluids $\left(358^{\circ} \mathrm{C}\right)$ observed in the PACMANUS field to date. Several areas of diffuse venting, including some emanating from anhydrite sand/talus, and occasional gray/black smoker fluids were observed on the flanks of the mound.

Another discrete area of hydrothermal activity was discovered during this expedition $\sim 8 \mathrm{~km}$ from PACMANUS on the northeast limb of Pual Ridge and named Northeast (NE) Pual (Fig. 5.1b). Fluids venting at NE Pual were predominantly low temperature/diffuse in nature in 2006 with maximum measured temperatures of $35^{\circ} \mathrm{C}$. The presence of extensive biological activity (snails, shrimp, mussel beds and microbial mats) and inactive sulfide chimneys suggests hydrothermal activity in this area is waning. 


\section{Methods}

\subsection{Sample collection}

All hydrothermal fluid samples were collected during the July-August 2006 MGLN06MV expedition to the Manus Basin aboard the R/V Melville. Fluids were collected using $150 \mathrm{~mL}$ titanium isobaric gas-tight (IGT) fluid samplers (Seewald et al., 2002) and 755mL titanium syringe 'major' samplers (Von Damm et al., 1985) deployed from the ROV Jason II. The temperatures of fluids collected with IGT samplers were monitored in real-time during collection using thermocouple temperature probes mounted adjacent to sampler snorkel tips. Only maximum temperatures for a given vent fluid are reported (uncertainty $\pm 2^{\circ} \mathrm{C}$ ) and temperatures were not measured in real time during deployment of the 'major' samplers. Two to three fluid samples were taken per discrete vent at all sites visited (typically two IGT samplers and one 'major' sampler) resulting in a total of 57 samples from 21 discrete vents at Vienna Woods and Pual Ridge (Table 5.1). In most cases, fluids were sampled after removing sulfide chimney structures.

After recovery of the ROV, fluid samples were processed on board the ship as soon as possible (typically within 12h). Fluids from IGT samplers were used for the analysis of both volatile $\left(\mathrm{H}_{2}, \mathrm{CH}_{4}, \mathrm{CO}, \mathrm{CO}_{2}, \mathrm{H}_{2} \mathrm{~S}\right)$ and dissolved inorganic constituents, whereas only the latter were analyzed from the 'major' samplers as they are not gas-tight. Fluid aliquots for major element ( $\left.\mathrm{Na}, \mathrm{Cl}, \mathrm{Ca}, \mathrm{K}, \mathrm{SiO}_{2}, \mathrm{SO}_{4}, \mathrm{Br}, \mathrm{F}\right)$ and trace metal (Fe, Mn, Li, B, Sr, Rb, Cs, Al)

determination were transferred to acid-cleaned high-density polyethylene (HDPE) Nalgene ${ }^{\mathrm{TM}}$ bottles and analyzed onshore. Aliquots for trace metal analysis were acidified with analyticalgrade Optima ${ }^{\circledR} \mathrm{HCl}$ prior to storage. Subsamples of acidified aliquots were diluted 100 -fold onboard ship and stored for shore-based measurement of aqueous silica $\left(\mathrm{SiO}_{2}\right)$. Prior to storage, separate fluid aliquots were sparged with $\mathrm{N}_{2}$ to remove all dissolved $\mathrm{H}_{2} \mathrm{~S}$ for analysis of $\mathrm{SO}_{4}$ 
concentration and $\mathrm{S}$ isotopic composition $\left(\delta^{34} \mathrm{~S}_{\mathrm{SO} 4}\right)$. Fluid aliquots for the onshore determination of aqueous $\Sigma \mathrm{CO}_{2}$ concentration and the stable carbon isotope composition of $\Sigma \mathrm{CO}_{2}\left(\delta^{13} \mathrm{C}_{\mathrm{CO} 2}\right)$ and $\mathrm{CH}_{4}\left(\delta^{13} \mathrm{C}_{\mathrm{CH} 4}\right)$ were stored in evacuated $25 \mathrm{~mL}$ serum vials sealed with butyl rubber stoppers. Fluid aliquots were also flame sealed in glass ampoules for $\mathrm{H}_{2} \mathrm{O}$ stable hydrogen $\left(\delta \mathrm{D}_{\mathrm{H} 2 \mathrm{O}}\right)$ and oxygen $\left(\delta^{18} \mathrm{O}_{\mathrm{H} 2 \mathrm{O}}\right)$ isotope analysis.

\subsection{Analytical methods}

Aqueous $\mathrm{H}_{2}, \mathrm{CH}_{4}$ and $\mathrm{CO}$ concentrations were determined onboard ship by molecular sieve gas chromatograph (GC) with thermal conductivity detection (for $\mathrm{H}_{2}$ and $\mathrm{CH}_{4}$ ) and helium ionization detection (for $\mathrm{CO}$ ) following a syringe headspace extraction. $\mathrm{pH}$ (at $25^{\circ} \mathrm{C}, 1 \mathrm{~atm}$ ) was measured potentiometrically onboard ship using a $\mathrm{Ag} / \mathrm{AgCl}$ combination reference electrode. Concentrations of total dissolved sulfide $\left(\Sigma \mathrm{H}_{2} \mathrm{~S}\right.$, hereafter abbreviated as $\left.\mathrm{H}_{2} \mathrm{~S}\right)$ were determined gravimetrically at WHOI following shipboard precipitation as $\mathrm{Ag}_{2} \mathrm{~S}$ in a 5wt.\% $\mathrm{AgNO}_{3}$ solution. $\mathrm{Ag}_{2} \mathrm{~S}$ precipitates were stored in $\mathrm{AgNO}_{3}$ solution for $\delta^{34} \mathrm{~S}$ analysis of $\mathrm{H}_{2} \mathrm{~S}\left(\delta^{34} \mathrm{~S}_{\mathrm{H} 2 \mathrm{~S}}\right)$. Dissolved inorganic carbon $\left(\Sigma \mathrm{CO}_{2}\right.$, hereafter abbreviated as $\left.\mathrm{CO}_{2}\right)$ concentrations were determined onshore after acidification of fluids with $25 \mathrm{wt} . \%$ phosphoric acid by injecting aliquots of headspace gas directly onto a $\mathrm{GC}$ with a Porapak ${ }^{\mathrm{TM}} \mathrm{Q}$ packed column and a thermal conductivity detector. These data were corrected to account for $\mathrm{CO}_{2}$ partitioning between the headspace and fluid phases within each individual serum vial. Dissolved gas concentrations are expressed in concentration units of either mmol/L fluid $\left(\mathrm{H}_{2} \mathrm{~S}, \mathrm{H}_{2}, \mathrm{CO}\right.$ and $\left.\mathrm{CH}_{4}\right)$ for gases analyzed at sea or $\mathrm{mmol} / \mathrm{kg}$ fluid $\left(\mathrm{CO}_{2}\right)$ for species analyzed in shore-based laboratories. The analytical uncertainty (2s) was $\pm 10 \%$ for $\mathrm{H}_{2}, \mathrm{CH}_{4}, \mathrm{CO}$ and $\mathrm{H}_{2} \mathrm{~S}$ concentrations, $\pm 5 \%$ for $\mathrm{CO}_{2}$ concentrations and \pm 0.02 for $\mathrm{pH}\left(25^{\circ} \mathrm{C}\right)$ measurements. 
The concentrations of the major elements $\left(\mathrm{Mg}, \mathrm{Na}, \mathrm{Cl}, \mathrm{Ca}, \mathrm{K}, \mathrm{SO}_{4}, \mathrm{Br}\right.$ and $\mathrm{F}$ ) were determined by ion chromatography. Concentrations of $\mathrm{Fe}, \mathrm{Mn}, \mathrm{Li}, \mathrm{Sr}, \mathrm{Rb}, \mathrm{Cs}$ and $\mathrm{Al}$ were determined by inductively coupled plasma-mass spectrometry (ICP-MS) at WHOI (see Craddock (2008) for details). Dissolved $\mathrm{SiO}_{2}$ and $\mathrm{B}$ concentrations were determined by inductively coupled plasma-optical emission spectrometry (ICP-OES) at the University of South Florida. To correct for the effects of sulfide precipitate formation within the fluid samplers, reported Fe data represent the 'total' concentrations obtained by summation of the dissolved and precipitated Fe fractions from a given sampler (Trefry et al., 1994; Craddock, 2008). The analytical uncertainty (2s) was $\pm 5 \%$ for $\mathrm{Mg}, \mathrm{Na}, \mathrm{Cl}, \mathrm{Ca}, \mathrm{K}, \mathrm{SO}_{4}, \mathrm{Br}$, and $\mathrm{F}$ concentrations, $\pm 10 \%$ for $\mathrm{Sr}, \mathrm{Li}, \mathrm{Rb}, \mathrm{Cs}, \mathrm{Fe}$, Mn and $\mathrm{Al}$ concentrations and $\pm 2 \%$ for $\mathrm{SiO}_{2}$ and $\mathrm{B}$ concentrations.

$\delta^{13} \mathrm{C}_{\mathrm{CO} 2}$ and $\delta^{13} \mathrm{C}_{\mathrm{CH} 4}$ values were determined at WHOI on a subset of samples by isotope ratio monitoring-gas chromatography mass spectrometry (irm-GC/MS) using a Finnigan Delta ${ }^{\text {Plus }}$ XL mass spectrometer interfaced to an Agilent 6890 gas chromatograph through a GCCIII interface (combustion furnace was held at $950^{\circ} \mathrm{C}$ for carbon isotope analysis). The pooled standard deviation (1s) is $0.3 \%$ for both $\delta^{13} \mathrm{C}_{\mathrm{CO} 2}$ and $\delta^{13} \mathrm{C}_{\mathrm{CH} 4}$ datasets. $\delta^{34} \mathrm{~S}_{\mathrm{H} 2 \mathrm{~S}}$ measurements were conducted on $\mathrm{Ag}_{2} \mathrm{~S}$ precipitates with an automated elemental analyzer interfaced with an isotope ratio mass spectrometer at the USGS, Denver. $\mathrm{SO}_{4}$ in selected fluid samples was precipitated as $\mathrm{BaSO}_{4}$ prior to $\delta^{34} \mathrm{~S}_{\mathrm{SO} 4}$ determination by the same method. Analytical uncertainty on all $\delta^{34} \mathrm{~S}$ data is $\pm 0.3 \%$ (2s). Oxygen isotope compositions of vent fluid $\mathrm{H}_{2} \mathrm{O}$ $\left(\delta^{18} \mathrm{O}_{\mathrm{H} 2 \mathrm{O}}\right)$ were analyzed using an automated $\mathrm{CO}_{2}$ equilibration device on a VG Optima mass spectrometer at the USGS, Denver. Hydrogen isotope compositions $\left(\delta \mathrm{D}_{\mathrm{H} 2 \mathrm{O}}\right)$ of vent fluid $\mathrm{H}_{2} \mathrm{O}$ were analyzed as $\mathrm{H}_{2}$ on a Finnigan MAT 252 mass spectrometer at the USGS, Denver. $\mathrm{H}_{2}$ was prepared by the $\mathrm{Zn}$ reduction technique (Kendall and Coplen, 1985) following salt removal by 
vacuum distillation. Analytical uncertainty $(1 \mathrm{~s})$ for $\delta^{18} \mathrm{O}_{\mathrm{H} 2 \mathrm{O}}$ and $\delta \mathrm{D}_{\mathrm{H} 2 \mathrm{O}}$ values are estimated to be 0.1 and $1.5 \%$, respectively.

Strontium isotope analyses $\left({ }^{87} \mathrm{Sr} /{ }^{86} \mathrm{Sr}\right)$ of fluids were conducted on a Finnigan MAT 261 thermal ionization mass spectrometer at the Freie Universität Berlin by static multi-collection (for further details see Eickmann et al. (2009)). External reproducibility of ${ }^{87} \mathrm{Sr} /{ }^{86} \mathrm{Sr}$ data is estimated to be on the order of $0.00007(2 \mathrm{~s})$ based on three individually processed aliquots of IAPSO reference seawater $\left({ }^{87} \mathrm{Sr} /{ }^{86} \mathrm{Sr} 0.709134( \pm 0.000066,2 \mathrm{~s}, \mathrm{n}=3)\right.$. Both this and the value for ambient bottom seawater in the Manus Basin (Table 5.1) are within error of the published value for seawater $\left(0.70916\right.$, Banner (2004)). With the exception of ${ }^{87} \mathrm{Sr} /{ }^{86} \mathrm{Sr}$, all stable isotope data are reported using standard delta notation. For the isotope of interest, $A, \delta A$ is defined by the following expression:

$$
\delta A(\%)=\left[\frac{R_{S}-R_{S T D}}{R_{S T D}}\right] \times 1000
$$

Where $R_{S}$ and $R_{S T D}$ are the isotope ratios of the sample and standard, respectively. $\delta^{13} \mathrm{C}_{\mathrm{CO} 2}$ values are expressed relative to the V-PDB scale, while all $\delta^{34} \mathrm{~S}$ data are and CDT scales. $\delta^{18} \mathrm{O}_{\mathrm{H} 2 \mathrm{O}}$ and $\delta \mathrm{D}_{\mathrm{H} 2 \mathrm{O}}$ values are both expressed relative to $\mathrm{V}-\mathrm{SMOW}$, with $\delta^{18} \mathrm{O}_{\mathrm{H} 2 \mathrm{O}}$ values representing isotope activity ratios and $\delta \mathrm{D}_{\mathrm{H} 2 \mathrm{O}}$ values representing concentration ratios as per convention (Shanks et al. 1995; Shanks, 2001).

\subsection{Calculation of endmember compositions}

The fluid samplers used in this study have finite snorkel and valve dead volumes that were filled with bottom seawater prior to deployment. Vent fluids can mix with seawater prior to venting at the seafloor (due entrainment within vent structures or in the subseafloor plumbing system) and/or during the sampling process (contamination), hence the composition of collected 
fluids invariably reflects two-component mixing of seawater and a hydrothermal fluid 'endmember'. The latter is conventionally assumed to be devoid of $\mathrm{Mg}$, reflecting the composition of fluids prior to any mixing with seawater. This assumption is based on experimental evidence for near-quantitative removal of $\mathrm{Mg}$ from seawater during hydrothermal interactions with basalt, andesite, and rhyolite at reaction zone conditions typical of seafloor hydrothermal systems (Bischoff and Dickson, 1975; Mottl and Holland, 1978; Seyfried and Bischoff, 1981; Hajash and Chandler, 1982; Shiraki et al., 1987; Ogawa et al., 2005). It has been suggested that the highly acidic nature of many backarc basin fluids may reverse Mg uptake reactions thereby invalidating the assumption that a near-zero $\mathrm{Mg}$ composition exists prior to seawater admixing (Gamo et al., 1997; Douville et al., 1999; Butterfield et al., 2003). For the purposes of our interpretations, however, calculated 'endmember' compositions are assumed to contain no $\mathrm{Mg}$ as per convention. This assumes all $\mathrm{Mg}$ in our samples is seawater-derived and while we proceed with the conventional approach, we acknowledge some unknown proportion may not be. Our interpretations would not change significantly if compositions were extrapolated to an arbitrary $\mathrm{Mg}$ value (e.g. the lowest observed $\mathrm{Mg}$ in a given vent field (Douville et al., 1999)). Extrapolation of compositions to the lowest measured $\mathrm{Mg}$ concentration at each vent (in an attempt to remove effects of sampling-related seawater contamination only) would preclude meaningful comparisons between fluids for species unaffected by seawater admixing prior to venting, due to variable dilution/concentration effects between vents with differing seawater entrainment. However, while anomalous endmember values can implicate seawater entrainment in modifying pre-existing endmember fluid compositions, they do not represent realistic compositions in cases where non-conservative species behavior has occurred during mixing. In such instances we occasionally discuss compositions at lowest measured $\mathrm{Mg}$ concentrations ('minimum $\mathrm{Mg}$ ') in addition to endmember values. 
Endmember compositions were calculated by extrapolating measured concentrations of individual species in multiple fluid samples from a given orifice to zero $\mathrm{Mg}$ concentration using a linear least squares regression weighted to pass through ambient bottom seawater concentrations (Tables 5.1 and 5.2; Von Damm et al., 1985). Endmember $\delta^{18} \mathrm{O}_{\mathrm{H} 2 \mathrm{O}}$ and $\delta \mathrm{D}_{\mathrm{H} 2 \mathrm{O}}$ values were calculated by extrapolation to zero $\mathrm{Mg}$ as per species concentrations. Measured $\delta^{13} \mathrm{C}_{\mathrm{CO} 2}$ values were corrected to endmember values assuming $2.3 \mathrm{mmol} / \mathrm{kg} \mathrm{CO}_{2}$ in entrained seawater (see Cruse and Seewald, 2006). In cases where multiple samples from a given vent orifice were analyzed, endmember $\delta^{13} \mathrm{C}_{\mathrm{CO} 2}, \delta^{13} \mathrm{C}_{\mathrm{H} 2 \mathrm{~S}}$ and $\delta^{34} \mathrm{~S}_{\mathrm{H} 2 \mathrm{~S}}$ values were averaged. Endmember ${ }^{86} \mathrm{Sr} /{ }^{86} \mathrm{Sr}$ ratios were calculated by extrapolating measured molar $\mathrm{Mg} / \mathrm{Sr}$ ratios to zero according to the method of (Albarède et al., 1981). 


\section{RESULTS}

\subsection{Temperature}

Focused high-temperature fluids with near zero measured $\mathrm{Mg}$ concentrations were sampled from each of the three main structures at Vienna Woods (Fig. 5.2a, Table 5.1). Despite being located 100-150m apart, the three fluids exhibited a narrow range of temperatures (273$285^{\circ} \mathrm{C}$ ) and compositions (Tables 5.1 and 5.2) suggesting that the Vienna Woods field is fed by a common source fluid. Measured temperatures, $\mathrm{pH}\left(25^{\circ} \mathrm{C}\right)$ and endmember fluid composition have remained relatively constant since previous expeditions in 1990 and 1995 (Lisitsyn et al., 1993; Auzende et al., 1996; Gamo et al., 1997; Douville et al., 1999; Fourre et al., 2006). In general, almost all aspects of the chemistry of fluids venting at Vienna Woods are similar to observations from basalt-hosted hydrothermal systems in MOR settings (Von Damm, 1995; German and Von Damm, 2003).

At Pual Ridge, focused fluids were sampled from 18 discrete orifices (Fig. 5.2b and 5.2c, Tables 5.1 and 5.2). Vent fluids sampled at Pual Ridge in 2006 show a wide range of temperatures in comparison to Vienna Woods. The hottest fluids were observed at the summit of the Fenway mound, where samples taken at F2 and F3 vents had maximum temperatures of $343^{\circ} \mathrm{C}$ and $358^{\circ} \mathrm{C}$, respectively (Table 5.1). Fluids at $\mathrm{F} 3$ vent exhibited a 'flashing' phenomenon whereby exiting fluid was highly reflective under ROV lighting, but changed to smoke-like precipitate a few $\mathrm{cm}$ above the orifice. The phenomenon can be attributed to vigorous two-phase fluid venting (Massoth et al., 1989; Hannington et al., 2001; Stoffers et al., 2006). At a depth of 1710m ( 171bar pressure) the fluid at F3 lies on the 2-phase boundary for a $3.2 \mathrm{wt} . \% \mathrm{NaCl}$ solution (Bischoff and Rosenbauer, 1985) consistent with subcritical boiling (Fig. 5.3). Measured temperatures at other vent areas on Pual Ridge were considerably lower than this. 


\section{2 $\mathrm{Mg}$ and $\mathrm{SO}_{4}$}

For most IGT samples taken at Vienna Woods, measured Mg is less than $1.6 \mathrm{mmol} / \mathrm{kg}$ the estimated maximum contribution of 'dead volume' seawater $\mathrm{Mg}$ for the sampler type $(<4 \mathrm{~mL}$, Seewald et al., 2002). Measured Mg concentrations from all IGT samples (3.63 - 50.6mmol/kg) at Pual Ridge, however, are greater than the expected 'dead volume' contribution (Table 5.1, Fig. 5.4). The lowest $\mathrm{Mg}$ samples at the former (less than $10 \%$ of seawater $\mathrm{Mg}$ ) were all from vents with temperatures greater than $300^{\circ} \mathrm{C}$ (Table 5.1). Many fluids sampled with both IGT and 'major' samplers have three near-identical measured Mg concentrations for different sampler types (RMR1, SM3, SC2, TK1, F2 and NP1 in Table 5.1). Sample sets from other vent fluids have two similar Mg values with a third (often suspected of accidental seawater entrainment) having much higher $\mathrm{Mg}$ (RMR2, RGR2, SC1, F1 and F5). It is unlikely that such consistently high $\mathrm{Mg}$ in repeat samples of a given vent fluid (with different sampler types) could be the result of accidental entrainment of near-identical amounts of seawater during each sampling event. These observations indicate that fluids exiting at the seafloor at Pual Ridge in 2006 all contain high concentrations of $\mathrm{Mg}$ relative to Vienna Woods fluids where $\mathrm{Mg}$ is near zero.

For all Vienna Woods samples, both measured $\mathrm{Mg}$ and $\mathrm{SO}_{4}$ concentrations decrease linearly to near zero (Fig. 5.4). In contrast, $\mathrm{SO}_{4}$ abundances in Pual Ridge vent fluids deviate from this behavior and both positive and negative endmember $\mathrm{SO}_{4}$ concentrations are apparent. $\delta^{34} \mathrm{~S}_{\mathrm{SO} 4}$ values for all Pual Ridge fluids (Table 5.1) lie within a narrow range $(+20.1$ to $+21.8 \%$ ) indicative of seawater-derived $\mathrm{SO}_{4}(+20.99 \%$; Rees et al., 1978). Consequently, we do not explicitly calculate zero $\mathrm{Mg}$ endmember $\mathrm{SO}_{4}$ concentrations are not as these would not reflect real compositions. Combined with high measured $\mathrm{Mg}$ concentrations, the predominance of seawater $\mathrm{SO}_{4}$ suggests that many (if not all) fluids venting at the seafloor at Pual Ridge mixed with seawater prior to venting. Low temperature fluids at Fenway $\left(\mathrm{F} 5,80^{\circ} \mathrm{C}\right)$ and NE Pual (NP1, 
$35^{\circ} \mathrm{C}$ ) are unique in that measured $\mathrm{SO}_{4}$ concentrations are similar to or slightly greater than ambient seawater, but $\mathrm{Mg}$ concentrations are lower (Table 5.1). Samples from both fluids therefore trend toward positive apparent endmember $\mathrm{SO}_{4}$ concentrations (Fig. 5.4).

\section{$4.3 \mathrm{pH}$}

Endmember $\mathrm{pH}$ values were not calculated because of the numerous reactions that influence $\mathrm{pH}$ during seawater entrainment, both during sampling and in the subsurface. The $\mathrm{pH}$ 's (measured at $25^{\circ} \mathrm{C}$ ) in low $\mathrm{Mg}(<5 \mathrm{mmol} / \mathrm{kg}$ ) samples from Vienna Woods are mildly acidic, ranging from 4.22 to 4.92 . In contrast, the $\mathrm{pH}$ of all PACMANUS fluids ranges from 2.32 to 5.90 (Table 5.1) and all high temperature $\left(>250^{\circ} \mathrm{C}\right)$ fluid samples at PACMANUS (excluding those suspected of seawater contamination during sampling) fall within a narrow range of 2.32 to 2.96. The low temperature NE Pual fluid had relatively high $\mathrm{pH}$ (6.88-6.94). These values are significantly lower than Vienna Woods, but comparable to values previously reported for other arc/back-arc hydrothermal systems (Fouquet et al., 1991a; Fouquet et al., 1993; Gamo et al., 1997; Nakagawa et al., 2006; Takai et al., 2008).

\section{$4.4 \mathrm{H}_{2}, \mathrm{H}_{2} \mathrm{~S}, \mathrm{CH}_{4}, \mathrm{CO}$ and $\mathrm{CO}_{2}$}

In general, endmember concentrations of $\mathrm{H}_{2}, \mathrm{H}_{2} \mathrm{~S}, \mathrm{CH}_{4}$ and $\mathrm{CO}_{2}$ in Vienna Woods fluids are uniform and relatively low compared to the known range of MOR fluid compositions (Von Damm, 1995; German and Von Damm, 2003). At Pual Ridge, however, significant variability is evident in endmember $\mathrm{H}_{2}, \mathrm{H}_{2} \mathrm{~S}, \mathrm{CH}_{4}$ and $\mathrm{CO}_{2}$ both between vent areas and within each area (Table 5.2). With the exception of the high value of fluid F3 $(306 \mu \mathrm{M})$, all endmember $\mathrm{H}_{2}$ concentrations are below $104 \mu \mathrm{M} . \mathrm{H}_{2}$ is generally low in fluids with lower measured exit temperatures, such as the Satanic Mills, Snowcap, and F5 fluids (Table 5.2, Fig. 5.5a). 
Endmember $\mathrm{H}_{2} \mathrm{~S}$ ranges from $2.8 \mathrm{mM}$ at Roger's Ruins to $20.8 \mathrm{mM}$ in high-temperature Fenway fluids and is highest in fluids with lower endmember $\mathrm{Cl}$ (Fig. 5.5c). $\delta^{34} \mathrm{~S}_{\mathrm{H} 2 \mathrm{~S}}$ values for PACMANUS are highly variable, with positive values $(0.0$ to $+4.4 \%)$ at Roman and Roger's Ruins but lower values $(-2.7$ to $+2.6 \%)$ at Satanic Mills, Snowcap and Fenway. The latter values are lower than the published range for unsedimented hydrothermal systems $(+1.4$ to $+8.6 \%$; Shanks, 2001).

Endmember $\mathrm{CO}_{2}$ values range from 4.38 to $4.48 \mathrm{mmol} / \mathrm{kg}$ at Vienna Woods and are comparable to the previously reported value for the site (6mM; Ishibashi et al., 1996). $\delta^{13} \mathrm{C}_{\mathrm{CO} 2}$ values range from $-5.2 \%$ to $-5.7 \%$ and are within the range of basaltic $\mathrm{CO}_{2}$ reported near Vienna Woods (-4.3\% to -11.3\%; Shaw et al., 2004). With the exception of NE Pual, all fluids at Pual Ridge have substantially higher endmember $\mathrm{CO}_{2}$ concentrations, ranging from $7.04 \mathrm{mmol} / \mathrm{kg}$ (at Roger's Ruins) to $274 \mathrm{mmol} / \mathrm{kg}$ at Satanic Mills (Table 5.2). Ishibashi et al. (1996) previously reported values of $20-40 \mathrm{mM}$ for the PACMANUS area but these data are minimum estimates because the samples were not acquired with gas-tight samplers. The highest $\mathrm{CO}_{2}$ concentrations, found in the lower $\mathrm{Cl}$ fluids at Snowcap and Satanic Mills (Fig. 5.5b, Table 5.2), are among the highest reported to date for vent fluids (Karl et al., 1988; Butterfield et al., 1990; Sakai et al., 1990a,b; Von Damm, 1995; German and Von Damm, 2003; Lupton et al., 2006) and are comparable to those observed in black smoker fluids at the back-arc JADE site, Okinawa Trough (Sakai et al., 1990b). In addition to the higher concentrations relative to Vienna Woods, $\mathrm{CO}_{2}$ is more ${ }^{13} \mathrm{C}$-enriched at PACMANUS, with endmember $\delta^{13} \mathrm{C}_{\mathrm{CO} 2}$ values varying from $-4.1 \%$ to 2.3\%o (Table 5.2).

At all PACMANUS areas, endmember $\mathrm{CH}_{4}$ concentrations are at the lower end of known compositions from MOR systems (German and Von Damm, 2003) but highly variable, ranging from $13.5 \mu \mathrm{M}$ at Fenway (F2) to a maximum of $78.1 \mu \mathrm{M}$ at Snowcap (SC2). Highest endmember 
$\mathrm{CH}_{4}$ concentrations are also evident in fluids with lower $\mathrm{Cl}$ contents (Fig. 5.5d). $\delta^{13} \mathrm{C}_{\mathrm{CH} 4}$ values (Table 5.2) at PACMANUS (-7.4\%o to -15.2\%o) are higher than Vienna Woods (-20.7\% to $20.8 \%$ ), but values from both areas overlap the range observed for other unsedimented MOR hydrothermal fluids (-8.0\% to $-20.8 \%$, (McCollom and Seewald, 2007). CO concentrations are also variable at PACMANUS (highest endmember CO concentration $(0.17 \mu \mathrm{M})$ at $\mathrm{F} 3$ vent) but CO was not detected in Vienna Woods fluids (Table 5.2).

\section{5 $\mathrm{Cl}, \mathrm{Br}$ and $\mathrm{F}$}

Whilst endmember $\mathrm{Cl}$ concentrations are uniformly $25-30 \%$ higher than ambient seawater at Vienna Woods, much greater variability is evident at Pual Ridge (Table 5.2). Fluids at Roger's and Roman Ruins are all enriched in $\mathrm{Cl}$ relative to seawater, with endmember concentrations of $551-731 \mathrm{mmol} / \mathrm{kg}$, whereas the other vent areas are both enriched and depleted relative to seawater, reaching a minimum value of $388 \mathrm{mmol} / \mathrm{kg}$ (Table 5.2). Fluids at Tsukushi, NE Pual and Fenway are enriched and depleted in $\mathrm{Cl}$ relative to seawater and fall within the above range. Endmember $\mathrm{Br}$ and $\mathrm{Cl}$ values at both Vienna Woods and Pual Ridge correlate well with each other and the majority of fluids have $\mathrm{Br} / \mathrm{Cl}$ ratios close to that of ambient seawater $(1.5$, Table 5.3). In contrast to Vienna Woods fluids, which are uniformly depleted in F, all Pual Ridge fluids are variably enriched in fluoride relative to seawater (Fig. 5.6). Endmember F values at PACMANUS are the highest reported to date for seafloor hydrothermal systems (Von Damm, 1995; German and Von Damm, 2003). F also exhibits similar variability to $\mathrm{CO}_{2}$ between vent fluids at Pual Ridge, with the highest concentrations of both at Snowcap, Satanic Mills and Fenway (Fig. 5.6). 


\section{$4.6 \delta^{18} \mathrm{O}_{\mathrm{H} 2 \mathrm{O}}$ and $\delta D_{\mathrm{H} 2 \mathrm{O}}$}

All vent waters at Vienna Woods have positive endmember $\delta \mathrm{D}_{\mathrm{H} 2 \mathrm{O}}$ and $\delta^{18} \mathrm{O}_{\mathrm{H} 2 \mathrm{O}}$ values (Fig. 5.7), resembling observations from MOR hydrothermal systems (Shanks et al., 1995; Shanks, 2001). In contrast, though all PACMANUS fluids have endmember $\delta^{18} \mathrm{O}_{\mathrm{H} 2 \mathrm{O}}$ values greater than those of Vienna Woods, the majority of $\delta \mathrm{D}_{\mathrm{H} 2 \mathrm{O}}$ values are substantially lower than seawater (Fig. 5.7). Thus, all PACMANUS fluid lie on a broad array of positive $\delta^{18} \mathrm{O}_{\mathrm{H} 2 \mathrm{O}}$ and negative $\delta \mathrm{D}_{\mathrm{H} 2 \mathrm{O}}$ values, the latter being among the most negative found to date in seafloor hydrothermal fluids (de Ronde, 1995; Shanks et al., 1995; Gamo et al., 1997; Shanks, 2001). Though there is no discernable trend between the individual vent areas (Fig. 5.7), the lowest $\delta \mathrm{D}_{\mathrm{H} 2 \mathrm{O}}$ value is at Snowcap (SC2).

\subsection{Alkalis, alkaline earths and B}

Because $\mathrm{Na}$ and other ionic species tend to co-vary with $\mathrm{Cl}$ due to charge balance constraints, concentrations are typically normalized to $\mathrm{Cl}$ to eliminate this variability (Von Damm, 1995). All fluids from both Pual Ridge and Vienna Woods have lower endmember $\mathrm{Na} / \mathrm{Cl}$ ratios than seawater (0.85), ranging from $0.76-0.84$ at PACMANUS/NE Pual and 0.74-0.76 at Vienna Woods (Table 5.3).

Both absolute and $\mathrm{Cl}$-normalized endmember $\mathrm{K}, \mathrm{Rb}$ and $\mathrm{Cs}$ concentrations are much higher in Pual Ridge fluids relative to Vienna Woods fluids (Tables 5.2 and 5.3), consistent with the higher abundances of these elements in EMVZ crustal rock relative to the MSC (Sinton et al., 2003). The maximum $\mathrm{K}$ endmember concentration at PACMANUS $(96.8 \mathrm{mmol} / \mathrm{kg}$, versus $21.2 \mathrm{mmol} / \mathrm{kg}$ at Vienna Woods) is one the highest reported to date and consistent with previously reported endmember values at PACMANUS (80-90mmol/kg; Gamo et al., 1996a). Pual Ridge 
fluids have a broader range of endmember Li concentrations $(0.475-1.33 \mathrm{mmol} / \mathrm{kg})$ than Vienna Woods $(1.07-1.16 \mathrm{mmol} / \mathrm{kg})$ but endmember $\mathrm{Li} / \mathrm{Cl}$ ratios overlap in both areas (Table 5.3).

With the exception of NE Pual which has an endmember Ca concentration of $84.8 \mathrm{mmol} / \mathrm{kg}$, Pual Ridge fluids have much lower Ca contents $(0.508-27.1 \mathrm{mmol} / \mathrm{kg})$ compared to Vienna Woods $(70.7-80.9 \mathrm{mmol} / \mathrm{kg})$. These trends are also apparent on a Cl-normalized basis (Table 5.3). There is substantial inter- and intra-field variability at PACMANUS with some fluids even having lower endmember $\mathrm{Ca} / \mathrm{Cl}$ ratios than seawater (Table 5.3). The highest endmember $\mathrm{Ca} / \mathrm{Cl}$ ratios are in the low temperature $\mathrm{F} 5$ and NP1 fluids (Table 5.2).

Endmember Sr concentrations are also much lower at PACMANUS compared to Vienna Woods (Tables 5.2 and 5.3), with NE Pual having anomalously high Sr. Sr exhibits similar variability to $\mathrm{Ca}$ in Pual Ridge fluids and the elements tend to co-vary on a Cl-normalized basis. At Snowcap, measured Sr values extrapolate to an apparent negative endmember of $-14.9 \mu \mathrm{mol} / \mathrm{kg}$, indicating significant non-conservative $\mathrm{Sr}$ behavior. The highest endmember $\mathrm{Sr}$ concentration $(352 \mu \mathrm{mol} / \mathrm{kg})$ and $\mathrm{Sr} / \mathrm{Cl}$ ratio are at $\mathrm{F} 5$ and NP1 vents (Table 5.2). Endmember ${ }^{87} \mathrm{Sr} /{ }^{86} \mathrm{Sr}$ ratios for PACMANUS fluids (Table 5.2) range from 0.69768 to 0.70429 and are lower than the Vienna Woods endmember (0.70435).

As shown in Tables 5.2 and 5.3, B is uniformly depleted $(<0.246 \mathrm{mmol} / \mathrm{kg})$ relative to seawater $(0.426 \mathrm{mmol} / \mathrm{kg})$ in Vienna Woods fluids but highly enriched in high temperature fluids at PACMANUS (up to $2.17 \mathrm{mmol} / \mathrm{kg}$ ). These upper values are high relative to MOR hydrothermal fluids (German and Von Damm, 2003), but within the range observed in other back-arc vent fluids (Ishibashi and Urabe, 1995). All low temperature fluids at Pual Ridge (F5, TK1 and NP1) are depleted in B below the level expected for conservative mixing of a fluid devoid of B with B-replete seawater. These compositions therefore yield apparent negative 
endmember B concentrations, indicating substantial non-conservative mixing behavior (Table 5.2).

\section{8 $\mathrm{Fe}, \mathrm{Mn}, \mathrm{Al}$ and $\mathrm{SiO}_{2}$}

Vienna Woods fluids were either clear or gray in color in 2006, which is consistent with the uniformly low endmember Fe (0.124-0.165mmol/kg; Table 5.2). Endmember Fe contents of Pual Ridge vent fluids are generally much higher and range from $0.076 \mathrm{mmol} / \mathrm{kg}$ at Snowcap (SC1) to $14.6 \mathrm{mmol} / \mathrm{kg}$ at Fenway (F2). The latter value is high compared to most MOR vent

fluids to date (Butterfield and Massoth, 1994; Von Damm, 1995; Charlou et al., 2002; Gallant and Von Damm, 2006). Fluids with the highest endmember Fe contents (F2 and F3 at Fenway) also have the highest measured temperatures but $\mathrm{Cl}$ values $<30 \%$ higher than seawater (Tables 5.1 and 5.2). There is also substantial variability between vent areas and within them at PACMANUS, with higher Mg fluids typically yielding lower endmember Fe values on a Cl-normalized basis (Table 5.2).

All Pual Ridge fluids are greatly enriched in Mn relative to Vienna Woods (Table 5.2), with endmembers ranging from 2.31 to $4.79 \mathrm{mmol} / \mathrm{kg}$. Similar to Fe, such Mn values are also among the highest reported for vent fluids to date (Ishibashi and Urabe, 1995; Von Damm, 1995; German and Von Damm, 2003). In contrast to Fe, however, there was less variability in Mn between vent areas or within them. Endmember Al contents at Vienna Woods are relatively uniform $(6.6-7.5 \mu \mathrm{mol} / \mathrm{kg})$ and while they much more variable in high temperature fluids at Pual Ridge (6.1-14.6 $\mu \mathrm{mol} / \mathrm{kg})$, concentrations are comparable between the two sites. Endmember $\mathrm{SiO}_{2}$ concentrations are also variable at Pual Ridge compared to Vienna Woods (14.6$15.3 \mathrm{mmol} / \mathrm{kg}$ ), ranging from 11.3 to $23.9 \mathrm{mmol} / \mathrm{kg}$ (Table 5.2 ). 


\section{DisCUSSION}

Convective hydrothermal systems driven by magmatic heat sources are expected to share several basic features regardless of host rock (substrate) composition and tectonic setting.

Seawater is typically assumed to enter the crust via a diffuse and poorly constrained 'recharge' zone and is subsequently heated to progressively higher temperatures. The hottest part of the hydrothermal reservoir - the 'reaction' or 'root' zone - is most likely adjacent to or above the magmatic intrusion, and is characterized by relatively low water/rock ratios. When buoyancy forces are sufficient to expel high temperature fluids from the hydrothermal reservoir, fluids rise toward the seafloor through a 'discharge' or 'upflow' zone under much higher water/rock ratios (Alt, 1995; Alt and Bach, 2003). Processes that can modify the composition of black smoker fluids during transit through such systems include: (i) water-rock (and/or sediment) interaction, (ii) phase separation, (iii) input of magmatic volatile species and (iv) and subsurface mixing with crustal seawater (Von Damm, 1995; German and Von Damm, 2003). Given the similarity of hydrothermal interactions (i) between seawater and basalt, andesite and rhyolite under experimental conditions (Bischoff and Dickson, 1975; Mottl and Holland, 1978; Seyfried and Bischoff, 1981; Hajash and Chandler, 1982; Shiraki et al., 1987; Ogawa et al., 2005), processes of Mg-fixation and anhydrite precipitation are expected to control $\mathrm{Mg}, \mathrm{Ca}$ and $\mathrm{SO}_{4}$ abundance during recharge of seawater into the crust at both Pual Ridge and Vienna Woods vent fields. Similarly, the abundances of other major elements $(\mathrm{Na}, \mathrm{Ca})$ are likely to be buffered by fluidmineral equilibria under reaction zone conditions, albeit at different compositions (Seyfried, 1987; Butterfield et al., 2003). In addition, phase separation (ii) should influence the abundances of elements if $P-T$ conditions within the hydrothermal reservoir reach the 2-phase boundary. Entrainment of magmatic volatiles (iii) most likely occurs near the 'reaction' zone, due to close proximity to the magma. Because of the relatively inert nature of MORB-derived volatiles, this 
process is unlikely to significantly alter the acidity of high temperature fluids in typical midocean ridge (MOR) systems (Butterfield et al., 2003). However, felsic-hosted magmatic hydrothermal systems are likely to differ substantially in this respect due to compositional differences in degassed volatiles (Yang and Scott, 2006). Significant modification of high temperature fluids by subsurface mixing (iv) has been recognized in MOR sites, such as the TAG hydrothermal mound on the Mid-Atlantic Ridge (Edmond et al., 1995; Tivey et al., 1995; Gamo et al., 1996b), North Cleft on the Juan de Fuca Ridge (Butterfield and Massoth, 1994) and Kairei Field, Central Indian Ridge (Gallant and Von Damm, 2006) and depends on the hydrologic regime in the 'upflow' zone. In the following discussion we examine the evidence for these four processes in the chemistry of Pual Ridge and Vienna Woods vent fields.

\subsection{Influence of water/rock reaction and substrate composition on fluid compositions}

\subsubsection{Fluid-mineral equilibria}

Elements whose abundances are controlled by temperature and pressure dependant fluidmineral equilibrium reactions, such as $\mathrm{Ca}$ and $\mathrm{Na}$ (Berndt et al., 1989; Berndt and Seyfried, 1993), exhibit similar trends in Manus Basin fluids to MOR hydrothermal systems and do not differ substantially as a function of substrate composition between Vienna Woods and Pual Ridge. While few experimental studies have examined felsic rock-seawater interactions under hydrothermal conditions, early experimental work has demonstrated that seawater interactions with more silicic rock compositions (rhyolite and andesite) broadly resemble those with basalt for many of these 'solubility-controlled' species (Hajash and Chandler, 1982; Shiraki et al., 1987). Endmember $\mathrm{Na} / \mathrm{Cl}$ ratios from Pual Ridge fluids overlap those at Vienna Woods and all are lower than the seawater ratio, suggesting removal of $\mathrm{Na}$ by albitization (Table 5.3). Though absolute $\mathrm{Ca}$ abundances in fluids from Pual Ridge have been variably modified by subsurface anhydrite 
deposition or dissolution (see below), endmember $\mathrm{Ca} / \mathrm{Cl}$ ratios from fluids with lowest $\mathrm{Mg}$ $(<5 \mathrm{mmol} / \mathrm{kg}$ ) are greater than seawater (Table 5.2), suggesting Ca addition presumably by the same process. Both $\mathrm{Ca} / \mathrm{Cl}$ and $\mathrm{Na} / \mathrm{Cl}$ ratios in the lowest $\mathrm{Mg}$ fluids at PACMANUS are within the ranges observed in unsedimented hydrothermal systems in MOR settings, suggesting that the compositional differences in substrate at Pual Ridge do not influence these elements substantially.

In addition to $\mathrm{Ca}$ and $\mathrm{Na}, \mathrm{Sr}$ abundance in hydrothermal fluids is also considered to be solubility-controlled (Berndt et al., 1988; Von Damm, 1988) and fluids from the Manus Basin also reflect this. Despite higher crustal abundances of $\mathrm{Sr}$ in crustal rocks of the EMVZ (Sinton et al., 2003), $\mathrm{Sr} / \mathrm{Cl}$ ratios in the lowest $\mathrm{Mg}$ fluids at Pual Ridge are lower than corresponding ratios at Vienna Woods. Like $\mathrm{Ca} / \mathrm{Cl}$ and $\mathrm{Na} / \mathrm{Cl}, \mathrm{Sr} / \mathrm{Cl}$ ratios in both settings are within the range observed in MOR hydrothermal systems (Gallant and Von Damm, 2006), suggesting similar solubility control. Even though endmember ${ }^{87} \mathrm{Sr} /{ }^{86} \mathrm{Sr}$ ratios at PACMANUS are variable (Fig. 5.8) due to non-conservative Sr behavior during seawater admixing (Section 5.4), endmember ratios calculated for lowest Mg fluids at Vienna Woods (0.70435) and PACMANUS (0.703940.70428 ) are consistent with a predominantly rock-derived source of Sr. Crustal ${ }^{87} \mathrm{Sr} /{ }^{86} \mathrm{Sr}$ ratios from Pual Ridge and surrounding areas fall in a narrow range of $0.703446-0.703690$, while MSC basalts have a ratio of 0.703275 (Kamenetsky et al., 2001; Marty et al., 2001; Sinton et al., 2003). A possible explanation for the slightly higher ${ }^{87} \mathrm{Sr} /{ }^{86} \mathrm{Sr}$ ratios in fluids least affected by subsurface mixing is that the Sr represents a mixture of seawater- and rock-derived Sr. Berndt et al. (1988) proposed a fluid reaction path model to explain the relationship between $\mathrm{Sr}$ abundance and ${ }^{87} \mathrm{Sr} /{ }^{86} \mathrm{Sr}$ ratios in MOR vent fluids whereby incomplete seawater Sr removal occurs during recharge (by anhydrite deposition), followed by subsequent addition of rock-derived Sr by dissolution of Ca- and Sr-bearing primary plagioclase minerals in high temperature reaction zones. Early stage precipitation would remove $\mathrm{Sr}$ without changing its isotopic composition 
while subsequent addition of rock $\mathrm{Sr}$ from plagioclase dissolution would give rise to decreased ${ }^{87} \mathrm{Sr} /{ }^{86} \mathrm{Sr}$ ratios and increased $\mathrm{Sr}$ concentrations.

Despite the high temperature of some fluids at PACMANUS (e.g. $358^{\circ} \mathrm{C}$ at F3), none of the sampled fluids are devoid of Mg as is typical at Vienna Woods and other MOR hydrothermal fluids. While we argue below (Section 5.4) that the majority of Mg in Pual Ridge fluids must be seawater-derived, an additional source of $\mathrm{Mg}$ cannot be excluded for the hottest fluid (F3). Two of the three samples from F3 have consistent measured $\mathrm{Mg}$ (4.52 and $4.74 \mathrm{mmol} / \mathrm{kg}$, Table 5.1) and temperatures $\left(358\right.$ and $356^{\circ} \mathrm{C}$, respectively). It is unlikely that these concentrations reflect entrainment of identical amounts of seawater during sampling, and they are greater than can be attributed to the dead volume of the IGT samplers (which accounts for $<1.6 \mathrm{mmol} / \mathrm{kg} \mathrm{Mg}$ in any given IGT sample). This implies a $\mathrm{Mg}$ content of $\sim 3 \mathrm{mmol} / \mathrm{kg}$ as the F3 fluid exited the seafloor at a temperature that places it on the boiling curve at seafloor pressure. It is unreasonable to conclude that this $\mathrm{Mg}$ could be derived from seawater mixing prior to venting as the required $\sim 5 \%$ mix of seawater would cool the fluid by $\sim 20^{\circ} \mathrm{C}$ below the two-phase boundary. The possibility exists that admixing of small amounts of a hotter seawater-like fluid occurred deep in the system and boiling occurred in response to decompression during upflow, but it is hard to envision a scenario whereby Mg-bearing seawater penetrates deep-seated reaction zones in such a hot and active system. An alternative explanation to account for this small, but significant concentration of $\mathrm{Mg}$, is that it reflects the enhanced solubility of Mg-aluminosilicates at the exceedingly low $\mathrm{pH}$ of this fluid (2.74). Indeed, the solubility of $\mathrm{Mg}$ in hydrothermal systems in general, can be represented by the reaction:

$$
\mathrm{Mg}^{2+}+4 / 3 \mathrm{SiO}_{2(\mathrm{aq})}+4 / 3 \mathrm{H}_{2} \mathrm{O}=1 / 3 \mathrm{Mg}_{3} \mathrm{Si}_{4} \mathrm{O}_{10}(\mathrm{OH})_{2}+2 \mathrm{H}^{+}
$$

where talc $\left(\mathrm{Mg}_{3} \mathrm{Si}_{4} \mathrm{O}_{10}(\mathrm{OH})_{2}\right)$ is used to represent more compositionally complex phases (Seyfried, 1987). The stoichiometry of this reaction indicates that at equilibrium the activity of $\mathrm{Mg}^{2+}$ will 
vary inversely with the square of $\mathrm{H}^{+}$activity. Accordingly, because vent fluids at PACMANUS are characterized by $\mathrm{pH}$ values within a range of 2 to 3 while $\mathrm{pH}$ typically varies from 3 to 4 in MOR systems (Von Damm, 1995; German and Von Damm, 2003), Mg activities at PACMANUS according to equation (3) or similar reactions may be 2 to 4 orders of magnitude higher at a given temperature, pressure and silica activity (Seyfried, 1987), possibly approaching the same order of magnitude as $\mathrm{Mg}$ contributions from sampler dead volume. Given the complex nature of $\mathrm{Mg}$ phases that may control Mg solubility (Seyfried, 1987) and limited thermodymanic data for these phases, however, further speculation is difficult. Regardless, the lowest measured $\mathrm{Mg}$ concentrations at PACMANUS are sufficiently close to zero that endmember compositions would not change substantially if these $\mathrm{Mg}$ values reflect true compositions prior to seawater admixing.

\subsubsection{Alkalis and $B$}

The influence of compositional differences in host rocks between the MSC and EMVZ is most apparent in the abundances of elements that are considered highly 'mobile' during fluidrock interactions. Field and laboratory data indicate that alkali elements are almost quantitatively partitioned into the fluid phase during high temperature fluid-rock interaction with basalt and more silicic rock compositions (Seyfried et al., 1984; Von Damm et al., 1985; Von Damm, 1990; Ogawa et al., 2005). Endmember abundances of the alkalis $\mathrm{K}, \mathrm{Rb}$ and $\mathrm{Cs}$ are highly elevated in PACMANUS fluids relative to Vienna Woods (Tables 5.2 and 5.3) and basalt-hosted MOR systems (German and Von Damm, 2003). This is entirely consistent with the greater abundances of these incompatible elements in arc-like EMVZ crust relative to the more mafic crust of the MSC (Kamenetsky et al., 2001; Sinton et al., 2003; Paulick et al., 2004; Monecke et al., 2007). In contrast to the other mobile alkalis, large differences in endmember Li concentrations are not evident between Vienna Woods and PACMANUS (Table 5.2). This observation is, however, 
also consistent with limited data suggesting the Li content of EMVZ crust ( $\sim 5-7 \mathrm{ppm})$ does not differ from that of the MSC basalt ( 5-8ppm) to the same extent as K, Rb and Cs (Sinton et al., 2003). In addition to differences in absolute abundances, endmember molar ratios of alkalis in Pual Ridge and Vienna Woods fluids are in reasonable agreement with the alkali ratios of the dominant rock compositions at each location (Fig. 5.9). B is also greatly enriched in most Pual Ridge fluids relative to Vienna Woods, consistent with greater B enrichment in more silicic rock compositions and the increased influence of recycled slab material as the arc is approached (Spivack and Edmond, 1987; Ryan and Langmuir, 1993). Because of the strong affinity of B for fluids, however, we cannot exclude magmatic degassing as an additional source of B to hydrothermal fluids at Pual Ridge (Ryan and Langmuir, 1993; Arnorsson and Andresdottir, 1995; Audetat et al., 1998).

If it is assumed that the mobile alkali elements $\mathrm{Rb}$ and $\mathrm{Cs}$ are quantitatively leached during hydrothermal alteration and do not undergo significant secondary mineral formation, effective water/rock (w/r) ratios can be calculated if fluid and rock concentrations are known (Von Damm et al., 1985). Rb and Cs contents vary widely in the EMB and along the MSC, however, as a result of highly varying substrate composition (Sinton et al., 2003). Using Rb $(0.9 \mathrm{ppm})$ and Cs $(0.018 \mathrm{ppm})$ contents from dredged basalt to the south of Vienna Woods (Sinton et al., 2003), calculated $w / r$ ratios for fluids there vary from 0.5 to 0.6 . Using values of $\mathrm{Rb}$ (27ppm) and Cs (0.8ppm) reported for Satanic Mills lava flows (Monecke et al., 2007), higher w/r ratios are calculated for high temperature $\left(>200^{\circ} \mathrm{C}\right)$ fluids at Pual Ridge, varying from 5 to 6 for $\mathrm{Rb}$ and 2 to 3 for Cs. Differences between these locations notwithstanding, the relatively low values combined with the alkali ratio patterns discussed above indicate hydrothermal fluids at both Pual Ridge and Vienna Woods have reacted with fresh crustal rocks under rock-dominated conditions (Seyfried and Mottl, 1982). 


\subsubsection{Quartz-fluid equilibrium and dissolved $\mathrm{SiO}_{2}$}

$\mathrm{SiO}_{2}$ contents in PACMANUS and NE Pual fluids, though highly variable, suggest considerable depths of hydrothermal circulation beneath Pual Ridge. The solubility of quartz in hydrothermal solutions is a strong function of temperature, pressure and to a lesser extent, salinity. Based on the assumption of quartz-fluid equilibrium at depth, dissolved $\mathrm{SiO}_{2}$ is commonly used as an indicator of maximum $P-T$ conditions encountered by hydrothermal fluids (Fournier, 1983; Von Damm et al., 1991; Foustoukos and Seyfried, 2007a). Using extrapolated (to zero Mg) vent temperatures and the quartz solubility data of (Von Damm et al., 1991), and $\mathrm{SiO}_{2}$ contents, RMR2 and RGR1 compositions suggest quartz-fluid equilibrium at pressure of 400-700 bar (Fig. 5.10). While the upper limit may be excessive, the lower limit suggest circulation depths in the vicinity of a possible magma body $\sim 2 \mathrm{~km}$ beneath the seafloor at Pual Ridge (Lee, 2003; Binns et al., 2007; Sun et al., 2007). There is a high degree of variability between co-located vents (e.g. RMR1 and RMR2), however, and shallower equilibration pressures ( $<300$ bars) are predicted for most other vents (Fig. 5.10). It has been suggested that the accuracy of the $\mathrm{SiO}_{2}$ geobarometer in felsic-hosted systems may be affected by reequilibration of $\mathrm{SiO}_{2}$ with quartz-rich wall-rock occurs during fluid upflow (Ishibashi and Urabe, 1995). Abundant subsurface quartz-bearing vesicles and veins observed in ODP drillcores from postulated upflow zones suggest that some $\mathrm{SiO}_{2}$ deposition has occurred during ascent of fluids to the seafloor at PACMANUS (Binns et al., 2007). While this process may be responsible for lower apparent equilibrium pressures, it cannot, however, explain the extremely high silica observed at RMR2 and RGR1.

In contrast, predicted equilibrium pressures (>1000bar) for all three vents at Vienna Woods imply an unreasonable depth of circulation there. A more plausible explanation is that extensive cooling of the Vienna Wood source fluid has occurred during upflow, as evidenced by 
the low Fe contents (Table 5.2) and the high dissolved $\mathrm{SiO}_{2}$ contents are merely a relic of much higher temperatures than those venting at the seafloor.

\subsection{4 pH and metal mobility}

The above observations suggest fluid-mineral buffering of major element abundances at depth. However, the $\mathrm{pH}$ of the lowest $\mathrm{Mg}$ samples at PACMANUS (2.62-2.74) is considerably more acidic than those observed during laboratory experiments that reacted seawater and rhyolite/dacite (3.5-4.5) at temperatures of $300-500^{\circ} \mathrm{C}$ (Hajash and Chandler, 1982; Shiraki et al., 1987). These experiments were conducted at 1 kbar pressure, however, which may be greater than reaction zone pressures encountered by fluids at PACMANUS where the seafloor pressure is $\sim 170$ bar. Owing to effects on fluid density and species dissociation equilibria, lower pressures tend to yield slightly lower measured $\mathrm{pH}$ values buffered by heterogeneous equilibrium reactions (Seyfried, 1987). However, such uniformly low $\mathrm{pH}$ values, such as those at PACMANUS, are not common in basalt-hosted hydrothermal systems at similar depths (Butterfield et al., 2003). Such high acidity in black smoker fluids have only been observed in other arc and back-arc settings such as the Vai Lili (Fouquet et al., 1991a,b; Fouquet et al., 1993) and Mariner fields (Seewald et al., 2005; Takai et al., 2008) in the Lau Basin. Low pH values (2.39 to 2.66) at Mariner are suggested to be the result of magmatic acid volatile $\left(\mathrm{SO}_{2}\right)$ degassing from underlying magmas (Seewald et al., 2005; Takai et al., 2008). As discussed below, we propose that aciditygenerating volatiles degassed at depth have contributed to the low $\mathrm{pH}$ values at PACMANUS also. In contrast, the much higher $\mathrm{pH}$ of Vienna Woods fluids (4.41-4.71) is more consistent with buffering by fluid-rock interactions alone.

The influence of acidity is apparent in the high Fe and Mn contents of PACMANUS

fluids. Experiments have demonstrated that Fe and Mn solubility during hydrothermal alteration 
of basalt and more felsic rock compositions is a complex and sensitive function of in situ $\mathrm{pH}$, in addition to temperature, pressure and fluid composition (Mottl et al., 1979; Hajash and Chandler, 1982; Rosenbauer and Bischoff, 1983; Seyfried and Janecky, 1985; Seyfried, 1987; Seewald and Seyfried, 1990). At PACMANUS, endmember Fe concentrations from low $\mathrm{Mg}(<5 \mathrm{mmol} / \mathrm{kg})$ fluids range from 6.86 to $14.6 \mathrm{mmol} / \mathrm{kg}$, with corresponding endmember Mn concentrations of 3.01 to $4.72 \mathrm{mmol} / \mathrm{kg}$. These are among the highest Fe and Mn contents reported to date for either arc or back-arc basin hydrothermal fluids (Ishibashi and Urabe, 1995). Higher values have been observed at the basalt-hosted North Cleft system (Butterfield and Massoth, 1994) and the ultramafic-hosted Rainbow site (Charlou et al., 2002). In the case of North Cleft, high endmember $\mathrm{Fe}$ concentrations are associated with extremely high $\mathrm{Cl}$ contents (in excess of $1000 \mathrm{mmol} / \mathrm{kg}$ ) that greatly enhance Fe solubility at high temperature. The comparatively low endmember $\mathrm{Cl}(698 \mathrm{mmol} / \mathrm{kg})$ in the vent fluid (F2) with highest endmember Fe content (Table 5.2) indicates that factors other than $\mathrm{Cl}$, such as $\mathrm{pH}$, temperature and pressure are responsible. $\mathrm{Fe}$ and Mn solubility are expected to be greatest at relatively low pressures, high temperatures and low $\mathrm{pH}$ values (Seyfried, 1987). Given that temperatures at PACMANUS do not appear to be anomalously high or pressures anomalously low relative to other hydrothermal systems, the exceptionally high dissolved Fe and Mn contents most likely reflects the highly acidic nature of these fluids.

The Fe and Mn contents of Vienna Woods fluids are in good agreement with experimental observations of their mobility from crystalline basalt as a function of temperature (Seewald and Seyfried, 1990). The extremely low Fe contents of fluids there (Table 5.2) are consistent with the low temperatures of venting as Fe mobility in endmember fluids is rapidly diminished below $300^{\circ} \mathrm{C}$ in the absence of any seawater admixing. Mn in hydrothermal fluids, which has sluggish kinetics of re-precipitation upon cooling, tends to reflect much hotter 
temperatures of mobilization. Based upon the experimental study of (Seewald and Seyfried, 1990), Mn concentrations in Vienna Woods fluids (Table 5.2) are more consistent with temperatures up to $\sim 350^{\circ} \mathrm{C}$. Such high temperatures in the reaction zone would reconcile the observations of high $\mathrm{SiO}_{2}$ for the temperatures of venting that yield unreasonable apparent depths of quartz-fluid equilibrium (Fig. 5.10).

\subsection{Phase separation and Cl variability}

Vienna Woods and Pual Ridge fluids exhibit variable enrichments or depletions in endmember $\mathrm{Cl}$ relative to seawater (Table 5.2). While we can demonstrate much of this variability is due to phase separation, prior magmatic- or rock-derived $\mathrm{Cl}$ inputs cannot be ruled out in the case of Pual Ridge fluids. Cl variations in MOR hydrothermal fluids beyond that permissible by rock hydration effects are typically attributed to phase separation (Von Damm, 1990; Von Damm, 1995; German and Von Damm, 2003; Foustoukos and Seyfried, 2007b) and rock-derived $\mathrm{Cl}$ is typically not considered a significant source to mid-ocean ridge vent fluids due to the low Cl content of MORB (Michael and Schilling, 1989; Michael and Cornell, 1998). Silicic crustal rocks in back-arc environments, however, have higher $\mathrm{Cl}$ contents (Wallace, 2005; Aiuppa et al., 2009) and dredged dacites from the vicinity of Pual Ridge contain up to $0.84 w t . \%$ $\mathrm{Cl}$ (Sun et al., 2007). However, quantitative leaching of such dacite at the water/rock ratios calculated previously ( 2 to 6 ) could only increase vent fluid chlorinity by $<120 \mathrm{mmol} / \mathrm{kg}$. Basalts from the MSC have lower $\mathrm{Cl}$ contents $(<0.15 \mathrm{wt} . \%$, Sinton et al. 2003), and complete leaching at calculated water/rock ratios $(\sim 0.5)$ could only enrich $\mathrm{Cl}$ in Vienna Woods fluids by $<50 \mathrm{mmol} / \mathrm{kg}$. Furthermore, while $\mathrm{Cl}$ enrichments might be possible, a solely rock-derived source of $\mathrm{Cl}$ cannot account for $\mathrm{Cl}$ depletions in Pual Ridge vent fluids. Input of $\mathrm{Cl}$ to Pual Ridge fluids from magmatic fluid degassing cannot be excluded, however, given the Cl-rich nature of Pual Ridge 
magmas (Sun et al., 2007), and the chlorinity of magmatic fluids may be substantially higher or lower than seawater. While we demonstrate below that phase separation influences species abundances at Pual Ridge, we do acknowledge that hydrothermal fluids undergoing phase separation there may have initial chlorinities different from seawater.

Conclusive evidence for subcritical phase separation at seafloor pressures was found at the Fenway site where the maximum measured temperature of $358^{\circ} \mathrm{C}$ at $\mathrm{F} 3$ vent places this fluid on the two-phase boundary for a fluid of seawater salinity (Fig. 5.3) at a seafloor pressure of 171 bar (Bischoff and Rosenbauer, 1985). The observed flashing and variability in dissolved major element and gas concentrations between multiple fluid samples collected at F3 (Table 5.1) are consistent with active boiling and partial segregation of a 2-phase emulsion of immiscible vapor/brine during venting at the seafloor (Bischoff and Pitzer, 1985; Hannington et al., 2001; Stoffers et al., 2006). Measured exit temperatures (Fig. 5.3) for all other vent fluids at PACMANUS and Vienna Woods lie well below the seawater two-phase boundary at seafloor pressures. If phase separation at depth has contributed to $\mathrm{Cl}$ variability, these fluids must have undergone substantial cooling prior to venting at the seafloor. As discussed in Section 5.4, there is substantial evidence to indicate mixing-related and possibly conductive cooling at Pual Ridge. At Vienna Woods, the low measured Mg concentrations preclude seawater mixing as a heat loss mechanism and extensive conductive cooling $\left(>100^{\circ} \mathrm{C}\right)$ is required to explain the low observed temperatures relative to the two-phase boundary (Fig. 5.3). As stated previously, Mn abundances in Vienna Woods fluids only suggest temperatures near $350^{\circ} \mathrm{C}$ and so it is possible that the high $\mathrm{Cl}$ endmembers do not reflect active phase separation at depth in 2006, but rather entrainment/depletion of residual brines formed during previous phase separation events (Shanks and Seyfried, 1987; Von Damm and Bischoff, 1987; Von Damm, 1988; Butterfield and Massoth, 1994; Butterfield et al., 1997; Schoofs and Hansen, 2000; Von Damm et al., 2005). Brine 
entrainment would be consistent with the chronic venting of Cl-rich fluids at Vienna Woods since 1990 (Lisitsyn et al., 1993; Auzende et al., 1996; Gamo et al., 1997; Douville et al., 1999; Fourre et al., 2006) and the apparent absence of any Cl-depleted conjugate fluids.

Measured temperatures below the two-phase boundary, notwithstanding, systematic compositional variability between fluids within several PACMANUS vent areas strongly suggest that fluid other than F3 are also influenced by phase separation. Endmember concentrations of soluble alkali elements $\mathrm{K}, \mathrm{Li}, \mathrm{Rb}$, and $\mathrm{Cs}$ show strong linear correlations with endmember $\mathrm{Cl}$ in areas with co-located vent fluids that extrapolate toward the origin (Fig. 5.11). Because these elements are readily mobilized from the crust during high temperature fluid-rock interaction (Seyfried et al., 1984; Von Damm et al., 1985; Von Damm, 1995) and they do not preferentially partition into the vapor phase (except under extreme conditions near halite saturation), alkali/Cl ratios are unaffected by phase separation (Berndt and Seyfried, 1990; Foustoukos and Seyfried, 2007b,c). This behavior implies phase separation and partial segregation of high and low salinity phases (Butterfield et al., 1994). Systematic variations in the endmember abundances of aqueous gases with $\mathrm{Cl}$ are also consistent with ongoing phase separation at PACMANUS. Endmember $\mathrm{CO}_{2}$ and $\mathrm{CH}_{4}$ concentrations at Fenway and Roman Ruins increase systematically with decreasing $\mathrm{Cl}$ (Figs. 5.5b and 5.5d), consistent with enhanced partitioning of volatile species into the lower salinity phases during phase separation. $\mathrm{H}_{2}$ and $\mathrm{H}_{2} \mathrm{~S}$ are much more variable (Figs. 5.5a and 5.5c) but these species may behave non-conservatively during seawater admixing in the subsurface (see below). Processes in addition to phase separation, however, must be invoked to explain the extreme enrichments in dissolved $\mathrm{CO}_{2}$ at Satanic Mills and Snowcap (Fig. 5.5b) and the lack of comparable enrichments in $\mathrm{CH}_{4}$ (Fig. 5.5d). In general, it is difficult to attribute enrichments of this magnitude in seafloor hydrothermal fluids with partitioning of $\mathrm{CO}_{2}$ into vapor phases 
(Butterfield et al., 1990; Butterfield et al., 1994; Butterfield et al., 2003; Seewald et al., 2003), and additional sources of $\mathrm{CO}_{2}$ such as magmatic degassing (discussed below) must be responsible.

\subsection{Magmatic fluid input at Pual Ridge}

The extensive vesicularity of felsic crust at Pual Ridge (Binns and Scott, 1993; Marty et al., 2001; Paulick et al., 2004) and the presence of vapor bubbles containing $\mathrm{H}_{2} \mathrm{O}, \mathrm{CO}_{2}$ and sulfur precipitates in accompanying melt inclusions (Yang and Scott, 1996; Kamenetsky et al., 2001; Kamenetsky et al., 2002; Yang and Scott, 2002) indicate that the magmas that formed these lavas were super-saturated with a volatile phase during eruption and emplacement. Yang and Scott (2005) suggested that fractional crystallization of magmas beneath Paul Ridge could sustain preeruptive degassing on timescales of several decades, comparable to the lifetimes of hydrothermal systems. Given that a magma body $2 \mathrm{~km}$ beneath the surface of Pual Ridge has been suggested (Lee, 2003; Binns et al., 2007; Sun et al., 2007) and the similar apparent depths of quartz-fluid equilibrium for some PACMANUS fluids discussed above, it is reasonable to assume circulating hydrothermal fluids there may reach sufficient depths to entrain fluids exsolved from degassing silicic magma.

\subsubsection{Isotopic evidence for magmatic $\mathrm{H}_{2} \mathrm{O}$}

Addition of magmatic water to Pual Ridge vent fluids is evident in the stark contrast in $\mathrm{H}_{2} \mathrm{O}$ isotopic composition there compared to fluids at Vienna Woods (Fig. 5.7) and it is clear that other processes cannot account for this observation. The stable isotopic composition of vent fluid $\mathrm{H}_{2} \mathrm{O}$ can record the integrated effects of three fundamental processes - water/rock (and/or sediment) interaction, phase separation and any contributions from extraneous magmatic waters. Hydration reactions between circulating hydrothermal fluids and igneous crust at high 
temperatures invariably yield a trend of increasing $\delta^{18} \mathrm{O}_{\mathrm{H} 2 \mathrm{O}}$ and $\delta \mathrm{D}_{\mathrm{H} 2 \mathrm{O}}$ values (relative to unmodified seawater) with decreasing water/rock ratios (Bowers and Taylor, 1985; Bowers, 1989; Shanks et al., 1995; Shanks, 2001). Incremental reaction path models of the isotopic evolution of these fluids indicate that the trajectory of such trends is a function of the mineral assemblage and the temperature of water/rock interaction, with increasing temperatures of reaction yielding greater $\delta \mathrm{D}_{\mathrm{H} 2 \mathrm{O}}$ increases relative to $\delta^{18} \mathrm{O}_{\mathrm{H} 2 \mathrm{O}}$. Compared to the reaction path models of Shanks et al. (1995), values at Vienna Woods suggest interactions between basaltic mineral assemblages and hydrothermal fluid at $\sim 300^{\circ} \mathrm{C}$ under water/rock ratios $\leq 1$, in line with observed temperatures and water/rock ratios calculated above $(\sim 0.5)$. While the more positive endmember $\delta^{18} \mathrm{O}_{\mathrm{H} 2 \mathrm{O}}$ values of the PACMANUS fluids are consistent with water/rock reaction at higher temperatures and/or lower water/rock ratios than Vienna Woods, alternate mechanisms must be invoked to explain the ubiquitous negative endmember $\delta \mathrm{D}_{\mathrm{H} 2 \mathrm{O}}$ values (Fig. 5.7).

Although phase separation is occurring at Pual Ridge (as discussed previously) and experimental studies have shown that both subcritical and supercritical phase separation processes occurring in seafloor hydrothermal systems can affect the hydrogen and oxygen isotopic composition of vent waters (Horita et al., 1995; Berndt et al., 1996; Shmulovich et al., 1999; Foustoukos and Seyfried, 2007b) this process cannot account for the observed hydrogen isotope composition of vent fluids there. Under most open- or closed-system scenarios for phase separation, vapor phases are slightly enriched in D relative to the heavily D-depleted brine phases while the reverse is true for oxygen isotope partitioning (Berndt et al., 1996; Foustoukos and Seyfried, 2007b). Examination of the PACMANUS fluids reveals no systematic variations in $\delta \mathrm{D}_{\mathrm{H} 2 \mathrm{O}}$ or $\delta^{18} \mathrm{O}_{\mathrm{H} 2 \mathrm{O}}$ with endmember $\mathrm{Cl}$ (Table 5.2). Furthermore, low chlorinity fluids have consistently negative $\delta \mathrm{D}_{\mathrm{H} 2 \mathrm{O}}$ and positive $\delta^{18} \mathrm{O}_{\mathrm{H} 2 \mathrm{O}}$, opposite to the trend expected for phase separation. While Berndt et al. (1996) propose that generation of a vapor phase with highly 
negative $\delta \mathrm{D}_{\mathrm{H} 2 \mathrm{O}}$ and positive $\delta^{18} \mathrm{O}_{\mathrm{H} 2 \mathrm{O}}$ values is conceivable under a scenario of combined water/rock reaction and open-system phase separation during isobaric heating (i.e. by subsurface dike emplacement), it requires segregation of a heavily distilled vapor (Foustoukos and Seyfried, 2007b). No such dilute vapors were observed at PACMANUS. Admixture of residual Ddepleted brine (Shanks and Seyfried, 1987; Von Damm and Bischoff, 1987) could contribute to the negative $\delta \mathrm{D}_{\mathrm{H} 2 \mathrm{O}}$ values in high chlorinity Roman/Roger's Ruins (Table 5.2), the lack of any consistent $\delta \mathrm{D}_{\mathrm{H} 2 \mathrm{O}}$ trend with endmember $\mathrm{Cl}$ renders this unlikely.

Negative $\delta \mathrm{D}_{\mathrm{H} 2 \mathrm{O}}$ values and positive $\delta^{18} \mathrm{O}_{\mathrm{H} 2 \mathrm{O}}$ values can be produced by extensive reaction of hydrothermal fluids with sedimentary overburden (Shanks et al., 1995; Von Damm et al., 2005). However, given the negligible sediment cover on the crest of Pual Ridge (Binns et al., 2007) and the lack of a thermogenic $\delta^{13} \mathrm{C}_{\mathrm{CH} 4}$ signature (Table 5.2; Welhan, 1988; Cruse and Seewald, 2006), there is no evidence to suggest that PACMANUS fluids have interacted with sediments.

Given the failure of the above processes to account for the array of negative $\delta \mathrm{D}_{\mathrm{H} 2 \mathrm{O}}$ and positive $\delta^{18} \mathrm{O}_{\mathrm{H} 2 \mathrm{O}}$ values at Pual Ridge, we propose that direct input of isotopically-distinct magmatic water to seawater-derived hydrothermal fluids is the most plausible explanation. The isotopic signature of 'juvenile' or mantle-derived magmatic water is estimated to have a narrow range of $\delta \mathrm{D}_{\mathrm{H} 2 \mathrm{O}}(-65 \pm 20 \%)$ and $\delta^{18} \mathrm{O}_{\mathrm{H} 2 \mathrm{O}}(+6 \pm 1 \%)$, (Taylor, 1979b; Ohmoto, 1986). In contrast, waters degassed from silicic arc magmas (subduction-related volcanic vapors, SRVV) may have much higher $\delta \mathrm{D}_{\mathrm{H} 2 \mathrm{O}}(-10$ to $-30 \%)$ and $\delta^{18} \mathrm{O}_{\mathrm{H} 2 \mathrm{O}}(+6$ to $+10 \%$ ) values (Giggenbach, 1992 ; Hedenquist and Lowenstern, 1994). Degassing-related fractionation and slab-derived seawater inputs can both increase the $\delta \mathrm{D}_{\mathrm{H} 2 \mathrm{O}}$ value of magmatic waters at convergent margins (Taylor, 1986; Giggenbach, 1992; Taylor, 1997; Pineau et al., 1998; Shaw et al., 2008). While it is impossible to accurately constrain the isotopic composition of magmatic water added, the array of 
PACMANUS isotopic compositions trends toward a D-depleted and highly ${ }^{18} \mathrm{O}$-enriched component similar to the SRVV compositions and does not lie within the trends expected for simple mixing of hydrothermal fluids with $\delta \mathrm{D}_{\mathrm{H} 2 \mathrm{O}}$ values of -40 to $-80 \%$ o (Fig. 5.7) suggested for fluids from the nearby DESMOS hydrothermal system (Gamo et al., 1997). Although the observed isotopic compositions at PACMANUS could reflect the addition of SRVV to unmodified seawater isotopic compositions, it is hard to envision a scenario where seawater could reach high temperature environments in the vicinity of a degassing magma chamber without extensive isotopic modification. The most likely scenario is that SRVV-like compositions are mixing with evolved (seawater-derived) hydrothermal fluids that have experienced extensive fluid-rock interaction (analogous to Vienna Woods) and have increased $\delta \mathrm{D}_{\mathrm{H} 2 \mathrm{O}}$ and $\delta^{18} \mathrm{O}_{\mathrm{H} 2 \mathrm{O}}$ values (Fig. 5.7).

A crude estimate of the minimum quantity of magmatic $\mathrm{H}_{2} \mathrm{O}$ added to circulating fluids can be constrained by simple hydrogen isotope mass balance. For this calculation we assume that the effects of phase separation on $\delta \mathrm{D}_{\mathrm{H} 2 \mathrm{O}}$ are negligible, magmatic $\mathrm{H}_{2} \mathrm{O}$ at all PACMANUS areas have a uniform $\delta \mathrm{D}_{\mathrm{H} 2 \mathrm{O}}$ of $-30 \%$ (the lower limit of SRVV compositions (Giggenbach, 1992; Hedenquist and Lowenstern, 1994)) and the circulating fluids into which magmatic waters are entrained have $\delta \mathrm{D}_{\mathrm{H} 2 \mathrm{O}}$ values similar to Vienna Woods fluids $(+2.4 \%$ o due to prior water/rock reaction. With these assumptions in mind, a $1 \mathrm{wt} \%$ magmatic $\mathrm{H}_{2} \mathrm{O}$ fraction is required to produce the composition observed in Roman Ruins fluid RMR1 (the highest $\delta \mathrm{D}_{\mathrm{H} 2 \mathrm{O}}$ value in Fig. 5.7). Fluid at the Snowcap SC2 vent would require a $20 \mathrm{wt} \%$ magmatic $\mathrm{H}_{2} \mathrm{O}$ fraction, with the majority of fluids within these two extremes. While these estimates are speculative and highly variable, they do suggest substantial quantities of magmatic water are entrained by circulating hydrothermal fluids. 


\subsubsection{Magmatic $\mathrm{CO}_{2}, \mathrm{~F}$, and $\mathrm{Cl}$}

Elevated abundances of aqueous $\mathrm{CO}_{2}$ in PACMANUS vent fluids are consistent with a direct contribution of magmatic volatiles because $\mathrm{CO}_{2}$ is invariably released from silicic magmas during cooling and crystallization (Carroll and Webster, 1994; Yang and Scott, 2006). Although some of the $\mathrm{CO}_{2}$ observed in PACMANUS fluids may be derived from rock leaching, unaltered subseafloor dacites recovered by ODP drilling at Snowcap, Roman Ruins and Satanic Mills contain less than 500 ppm residual $\mathrm{CO}_{2}$ (Paulick et al., 2004). Assuming quantitative mobilization, this limits the total amount of $\mathrm{CO}_{2}$ that can be derived by substrate leaching to $<6 \mathrm{mmol} / \mathrm{kg}$ for the range of water/rock ratios calculated using alkali abundances $(2-6)$.

Concentrations of aqueous $\mathrm{CO}_{2}$ in basalt-hosted mid-ocean ridge vent fluids that approach values observed at PACMANUS have also been attributed to active magmatic degassing (Butterfield et al., 2003; Lilley et al., 2003; Seewald et al., 2003). While primary $\mathrm{CO}_{2}$ contents of parental magmas at PACMANUS are poorly constrained (Marty et al., 2001), weight percent additions of magmatic $\mathrm{H}_{2} \mathrm{O}$ (estimated above) indicate that $\mathrm{CO}_{2}$ is far less abundant than $\mathrm{H}_{2} \mathrm{O}$ in the magmatic fluids being added. The exsolution of a water-dominated magmatic fluid suggests relatively shallow (crustal) magma chamber (Yang and Scott, 2006), consistent with the speculation of a fractionating silicic magma body beneath Pual Ridge (Lee, 2003; Yang and Scott, 2005; Binns et al., 2007; Sun et al., 2007).

Examination of the carbon isotopic composition of vent fluid $\mathrm{CO}_{2}$ at PACMANUS (-4.1 to $-2.3 \%$ ) reveals a more ${ }^{13} \mathrm{C}$ enriched $\mathrm{CO}_{2}$ source relative to Vienna Woods fluids (-5.2 to $5.7 \%$ ), which likely reflects the closer proximity of the latter to the New Britain Arc (80km vs. $220 \mathrm{~km}$ ) and a larger contribution of more ${ }^{13} \mathrm{C}$-enriched slab-derived carbon. $\delta^{13} \mathrm{C}_{\mathrm{CO} 2}$ values in fluids from unsedimented hydrothermal systems measured to date range from $-3.15 \%$ to $-13.0 \%$ o (Charlou et al., 1996; Charlou et al., 2002; McCollom and Seewald, 2007) but the majority of 
typical basalt-hosted fluids range from $-4 \%$ to $-9 \%$ (Kelley et al., 2004), reflecting the composition of primitive mantle $\mathrm{CO}_{2}(-5 \%$ o to $-8 \%$; Pineau et al., 1976; Taylor, 1986; Cartigny et al., 2001; Coltice et al., 2004). Based on the few studies conducted to date, dissolved $\mathrm{CO}_{2}$ in back-arc hydrothermal fluids are typically more ${ }^{13} \mathrm{C}$-enriched, with $\delta^{13} \mathrm{C}_{\mathrm{CO} 2}$ values ranging from $+0.4 \%$ at Mariner (Lau Basin) to $-6.2 \%$ at White Lady (N.Fiji Basin), (Ishibashi et al., 1994; Takai et al., 2008). Vent fluid $\delta^{13} \mathrm{C}_{\mathrm{CO} 2}$ values higher than putative mantle carbon values can arise from two potential processes $-{ }^{13} \mathrm{C}$ enrichment in the source magma due to slab-derived carbonate inputs and/or degassing-related fractionation effects. In the case of the latter, the $\mathrm{CO}_{2}$ initially degassed from basaltic magmas can be enriched in ${ }^{13} \mathrm{C}$ by several per mil (i.e. 2.2 to $4.3 \%$ at $>1100^{\circ} \mathrm{C}$ ) relative to the undegassed bulk $\mathrm{CO}_{2}$ reservoir (Javoy et al., 1978; Mattey, 1991). Such enrichments, however, are only associated with the earliest stages of $\mathrm{CO}_{2}$ exsolution (Tsunogai et al., 1994) and cannot account for $\mathrm{CO}_{2}$ observed in PACMANUS fluids since the extremely low $\mathrm{CO}_{2}$ contents (Marty et al., 2001) and low $\delta^{13} \mathrm{C}_{\mathrm{CO} 2}$ values observed in EMVZ lavas (down to 33.2\%; Shaw et al., 2004) suggest extensive degassing of crustal magmas. The ${ }^{13} \mathrm{C}$-enriched nature of aqueous $\mathrm{CO}_{2}$ at PACMANUS therefore may reflect the greater influence of slab-derived carbon on the magma source in this region of the basin. Subducted oceanic crust can contain sedimentary organic carbon/carbonate and carbonates formed during low temperature alteration of basaltic rocks (Alt and Teagle, 1999; Coltice et al., 2004), giving a bulk slab $\delta^{13} \mathrm{C}$ value of approximately $-1 \%$ (see Coltice et al., 2004). Numerous geochemical proxies (e.g. higher $\mathrm{Ba} / \mathrm{Nb}$ and $\mathrm{Cl} / \mathrm{Nb}$ ratios in dredged lavas) indicate greater subduction-related inputs to magmas in the EMVZ (and Pual Ridge) relative to the MSC (Kamenetsky et al., 2001; Sinton et al., 2003; Sun et al., 2004; Pearce and Stern, 2006; Park et al., in press) and inputs of slab-derived carbon have been suggested (Shaw et al., 2004). Trends of increasing $\delta^{13} \mathrm{C}_{\mathrm{CO} 2}$ with arc proximity have been 
observed in other back-arc vent fluids, such as the Lau Basin (Proskurowski et al., 2006) and the Okinawa Trough/Mariana Arc (cf. Sakai et al. (1990b) and Lupton et al. (2006)).

High concentrations of magmatic $\mathrm{CO}_{2}$ in PACMANUS vent fluids are also accompanied by elevated fluoride (F) abundances (Fig. 5.6), which may reflect inputs of F to convecting hydrothermal fluids from magmatic degassing. Fluoride species are enriched in felsic magmas (Carroll and Webster, 1994) and are common constituents of exsolved magmatic gases in arc-type environments (Yang and Scott, 2006; Aiuppa et al., 2009). In contrast to Pual Ridge, vent fluids at Vienna Woods (Fig. 5.6) and MOR hydrothermal systems are depleted in F relative to seawater (Edmond et al., 1979a; Maris et al., 1984; Von Damm et al., 1985; Seyfried and Ding, 1995a; German and Von Damm, 2003). Despite this circumstantial evidence, however, we cannot discount additional rock-derived sources of $\mathrm{F}$. The behavior of $\mathrm{F}$ in seafloor hydrothermal systems is not completely understood (Seyfried and Ding, 1995a) and limited experimental evidence suggests both mineralogical sources and sinks of $\mathrm{F}$ are possible during hydrothermal alteration of silicic rock compositions (Galluccio et al., 2009). Rock leaching has also been proposed as a source of $\mathrm{F}$ to some felsic-hosted terrestrial geothermal systems (Arnorsson et al., 1978). The F contents of unaltered Pual Ridge dacites (360 to 530ppm,; Paulick et al., 2004) are not substantially different from MSC basalts ( 200ppm; Sinton et al., 2003) and typical MORB ( $\sim 500 \mathrm{ppm}$; Michael and Schilling, 1989). Even inefficient leaching at calculated $\mathrm{w} / \mathrm{r}$ ratios $(\sim 0.5$ for Vienna Woods, 2-6 for Pual Ridge) could yield aqueous F concentrations several times that of seawater in either setting. If mobilization of rock-derived $\mathrm{F}$ is occurring, some solubility control as a function of substrate must be invoked as F enrichments in Pual Ridge fluids and depletions at Vienna Woods do not reflect crustal compositions. Therefore, while the correlation of $\mathrm{F}$ with magmatic $\mathrm{CO}_{2}$ is suggestive of a relationship, further constraints are needed on the mobility of $\mathrm{F}$ 
in hydrothermal systems before the excess abundances relative to typical MOR hydrothermal fluids can be attributed to magmatic degassing with confidence.

In addition to $\mathrm{CO}_{2}$ and $\mathrm{F}$, magmatic fluids at Pual Ridge could also contain varying amounts of $\mathrm{Cl}$ but we cannot constrain such inputs, however, owing to the high quantities of seawater $\mathrm{Cl}$ and variability arising from phase separation. Exsolved magmatic fluids may also be characterized by chlorinities comparable to or much lower than seawater. At supercritical magmatic temperatures and shallow crustal pressures, Cl-bearing magmatic fluids can separate into low-Cl vapor phases containing the bulk of $\mathrm{H}_{2} \mathrm{O}$ mass and small quantities of a Cl-rich brine condensate (Cline and Bodnar, 1991; Shinohara, 1994; Kelley and Früh-Green, 2000; Lowenstern, 2000; Webster, 2004). Additional lines of evidence, such as $\mathrm{Br} / \mathrm{Cl}$ ratios, would not be useful in identifying the addition of magmatic fluids because molar $\mathrm{Br} / \mathrm{Cl}$ ratios in high temperature $\left(>700^{\circ} \mathrm{C}\right)$ fumaroles from western Pacific arc volcanoes (0.6 to 1.4; Goff and McMurtry, 2000; Snyder et al., 2002) approach those of the seawater value of 1.5. Most Pual Ridge fluids do not deviate from the latter ratio (Table 5.3).

\subsubsection{Magmatic $\mathrm{SO}_{2}$ input and disproportionation}

There is some indirect evidence to suggest that magmatic fluids entrained by Pual Ridge vent fluids are accompanied by S species that could generate substantial acidity. We conclude, however, that much of the primary signature of magmatic S has likely been considerably overprinted by secondary processes subsequent to magmatic degassing and prior to seafloor venting. Exsolved $\mathrm{CO}_{2}$ and $\mathrm{H}_{2} \mathrm{O}$-rich vapor bubbles in melt inclusions from Pual Ridge contain a host of sulfate- and sulfide-bearing minerals, indicating that sulfurous species have partitioned from magmas into exsolved aqueous fluids there (Kamenetsky et al., 2001; Kamenetsky et al., 2002; Yang and Scott, 2006). In contrast to basaltic magmas, where it exists mostly as sulfide, 
total $\mathrm{S}$ in more oxidizing (higher $f_{\mathrm{O} 2}$ ) calc-alkaline magmas is predominantly in the forms $\mathrm{SO}_{2}$ and $\mathrm{SO}_{4}$ (Burnham, 1979; Carroll and Rutherford, 1988; Nilsson and Peach, 1993; Carroll and Webster, 1994). $\mathrm{SO}_{2}$ strongly partitions into exsolved aqueous fluids during magmatic degassing (Burnham, 1979; Scaillet and Pichavant, 2003) and upon cooling below $\sim 400^{\circ} \mathrm{C}, \mathrm{SO}_{2}$ can undergo either of the following disproportionation reactions (Iwasaki and Takejiro, 1960; Holland, 1965; Drummond, 1981; Kusakabe et al., 2000):

$$
\begin{gathered}
4 \mathrm{SO}_{2}+4 \mathrm{H}_{2} \mathrm{O} \rightarrow \mathrm{H}_{2} \mathrm{~S}+3 \mathrm{H}_{2} \mathrm{SO}_{4} \\
3 \mathrm{SO}_{2}+3 \mathrm{H}_{2} \mathrm{O} \rightarrow \mathrm{S}^{0}+2 \mathrm{H}_{2} \mathrm{SO}_{4}
\end{gathered}
$$

Where $\mathrm{S}^{0}$ is zero-valent sulfur. According to Kusakabe et al.(2000), reaction (1) is more favored under higher temperatures and lower $\mathrm{SO}_{2}$ contents than reaction (2). Both reactions are rapid, produce sulfuric acid $\left(\mathrm{H}_{2} \mathrm{SO}_{4}\right.$, which generates acidity upon dissociation to $\mathrm{HSO}_{4}{ }^{-}$and $\left.\mathrm{H}^{+}\right)$and are associated with significant sulfur isotope fractionations between reactant $\mathrm{SO}_{2}$ and the oxidized and reduced $\mathrm{S}$ products. $\mathrm{H}_{2} \mathrm{SO}_{4}$ is typically enriched in ${ }^{34} \mathrm{~S}$, while $\mathrm{H}_{2} \mathrm{~S}$ and $\mathrm{S}^{0}$ are depleted in ${ }^{34} \mathrm{~S}$ relative to precursor $\mathrm{SO}_{2}$ (Ohmoto and Rye, 1979; Ohmoto and Goldhaber, 1997; Kusakabe et al., 2000). The $\mathrm{SO}_{4}$ produced invariably has a $\delta^{34} \mathrm{~S}_{\mathrm{SO} 4}$ that is lower than seawater $(+20.99 \%$; Rees et al., 1978), while negative $\delta^{34} \mathrm{~S}_{\mathrm{H} 2 \mathrm{~S}}$ values would be expected for $\mathrm{H}_{2} \mathrm{~S}$ assuming an initial magma $\delta^{34} \mathrm{~S}$ near 0\%o (Ohmoto and Goldhaber, 1997).

Negative $\delta^{34} \mathrm{~S}_{\mathrm{H} 2 \mathrm{~S}}$ values are observed in fluids from some areas of PACMANUS (Satanic Mills and Snowcap) and are associated with extremely high levels of magmatic $\mathrm{CO}_{2}$ (Fig. 5.12). $\delta^{34} \mathrm{~S}_{\mathrm{H} 2 \mathrm{~S}}$ values from unsedimented MOR hydrothermal systems range from $+1.4 \%$ to $+8.6 \%$, reflecting a mixture of both reduced seawater $\mathrm{SO}_{4}$ and basaltic $\mathrm{S}$ (Shanks, 2001 and refs. therein). More negative values are possible in sedimented hydrothermal systems due to the presence of ${ }^{34} \mathrm{~S}-$ depleted sedimentary sulfide minerals. The most negative $\delta^{34} \mathrm{~S}_{\mathrm{H} 2 \mathrm{~S}}$ values (as low as $-5.7 \%$ ) observed to date were in fluids from the DESMOS Caldera site to the east of Pual Ridge in 1995 
and were attributed to magmatic $\mathrm{SO}_{2}$ disproportionation (Gamo et al., 1997). As stated previously, there is no evidence to suggest fluids at Pual Ridge have interacted with sediments and the most plausible explanation for the above trend is that some of the $\mathrm{H}_{2} \mathrm{~S}$ in Satanic Mills and Snowcap fluids is derived either directly from magmatic $\mathrm{SO}_{2}$ disproportionation, or possibly by reduction of magmatic $\mathrm{SO}_{4}$ with low $\delta^{34} \mathrm{~S}_{\mathrm{SO} 4}$ values.

In contrast to $\delta^{34} \mathrm{~S}_{\mathrm{H} 2 \mathrm{~S}}, \delta^{34} \mathrm{~S}_{\mathrm{SO} 4}$ values for all Pual Ridge fluids do not deviate significantly from that of seawater-derived $\mathrm{SO}_{4}$ (Table 5.1) and are inconsistent with a magmatic origin for $\mathrm{SO}_{4}$ in the fluids. The general absence of anomalous $\delta^{34} \mathrm{~S}_{\mathrm{SO} 4}$ compositions that might be expected from addition and disproportionation of magmatic $\mathrm{SO}_{2}$, however, is not surprising considering the strong retrograde solubility of anhydrite as a function of temperature (Bischoff and Dickson, 1975; Bischoff and Seyfried, 1978; Mottl and Holland, 1978). If it is assumed that magmatic fluids are entrained (and therefore diluted) by circulating high-temperature fluids at considerable depth in the hydrothermal reservoir (possibly near the high temperature reaction zone) any $\mathrm{SO}_{4}$ added could be quantitatively removed as anhydrite if a continuous supply of $\mathrm{Ca}$ is available from fluid-mineral equilibrium reactions. The widespread occurrence of anhydrite in the subsurface (Binns et al., 2007) and the extensive removal of seawater sulfate evident in present-day Snowcap fluids (Fig. 5.4) is an indication of the ability the former mechanism to overwhelm a magmatic source of $\mathrm{SO}_{4}$.

Our observations are consistent with evidence to suggest variable magmatic $\mathrm{SO}_{2}$ input and disproportionation has occurred in PACMANUS fluids in the past. Two independent investigations arising from ODP Leg 193 demonstrated $\delta^{34} \mathrm{~S}_{\mathrm{SO} 4}$ values as low as $+16.6 \%$ (Craddock, 2008) and $+18.1 \%$ (Roberts et al., 2003) in anhydrite deposited beneath Snowcap, with trends of decreasing $\delta^{34} \mathrm{~S}_{\mathrm{SO} 4}$ with increasing depth below the seafloor. These trends were interpreted to be the result of precipitation from fluids with variable mixtures of both seawater- 
and magmatic $\mathrm{SO}_{2}$-derived $\mathrm{SO}_{4}$, with the proportion of the latter increasing with depth beneath the Snowcap dome. Several inactive outcrops of bleached volcaniclastic material cemented with native sulfur $\left(\mathrm{S}^{0}\right)$ were also found in the vicinity of Snowcap (Tivey et al., 2006), suggesting that acid-sulfate fluids may have reached the seafloor in the past.

The extremely high Fe contents of many PACMANUS fluids suggests that magmaticderived acidity has lead to extensive dissolution of Fe from silicate minerals in the subsurface, which could have consumed $\mathrm{H}^{+}$and raised in situ $\mathrm{pH}$. Measured $\mathrm{pH}$ values are still lower than experimental observations of equilibrium buffering by the andesite/dacite mineral assemblage (Hajash and Chandler, 1982; Shiraki et al., 1987), suggesting that titration of magmatic acidity may be incomplete. One possible explanation is that rocks in the upflow zones at Pual Ridge may be completely altered and characterized by mineral assemblages that are stable at low $\mathrm{pH}$, as suggested by ODP Leg 193 observations beneath Snowcap (Binns et al., 2007). The latter would likely be incapable of buffering $\mathrm{pH}$ values to the same extent as fresh andesite/dacite mineral assemblages. While alkali abundances and ratios (Fig. 5.9) clearly indicate fluid interactions with fresh rock, this may simply reflect water-rock interaction prior to magmatic fluid addition.

\subsubsection{Spatial variability of magmatic fluid inputs}

Our data are remarkably consistent with ODP Leg 193 observations which demonstrated apparent spatial variability of magmatic inputs within the PACMANUS vent field. Observations of anomalous subsurface anhydrite $\delta^{34} \mathrm{~S}_{\mathrm{SO} 4}$ values, rare-earth element patterns and 'acid-sulfate' (quartz-illite-pyrophyllite-anhydrite) alteration assemblages were limited to the Site 1188 (beneath the Snowcap Dome) and were lacking at Site 1189 (Roman Ruins), (Bach et al., 2003; Roberts et al., 2003; Binns et al., 2007; Craddock, 2008). The data collected in 2006 demonstrates that vent fluids from Snowcap and the nearby Satanic Mills area clearly contain the 
strongest signatures of $\mathrm{H}_{2} \mathrm{O}, \mathrm{CO}_{2}, \mathrm{H}_{2} \mathrm{~S}$, and possibly $\mathrm{F}$ of magmatic origin. What is perplexing, however, is that while there is a notable absence of extremely high concentrations of $\mathrm{CO}_{2}$ and anomalous $\delta^{34} \mathrm{~S}_{\mathrm{H} 2 \mathrm{~S}}$ values in Roman and Roger's Ruins vent fluids, $\delta \mathrm{D}_{\mathrm{H} 2 \mathrm{O}}$ and $\mathrm{pH}$ values there resemble those of low $\mathrm{Mg}$ fluids from Satanic Mills and are consistent with magmatic inputs. Given the poor constraints on compositional variability of magmatic fluids in backarc systems, the high degrees of dilution by circulating hydrothermal fluids, it may be that magmatic fluid compositions at Roman and Roger's Ruins contain lower amounts of $\mathrm{CO}_{2}$ and $\mathrm{SO}_{2}$, with small $\mathrm{SO}_{2}$-derived $\delta^{34} \mathrm{~S}_{\mathrm{H} 2 \mathrm{~S}}$ anomalies suffering extensive overprinting. While we acknowledge it is also possible that Roman and Roger's Ruins fluids may not be entraining magmatic fluids at depth, this would require some unknown alteration assemblage capable of buffering both $\mathrm{pH}$ and $\delta \mathrm{D}_{\mathrm{H} 2 \mathrm{O}}$ values to the same extent as the as Snowcap, Satanic Mills and Fenway fluids, and there is no evidence as yet to suggest this is plausible.

\subsection{Subsurface seawater entrainment}

The large number of sample sets taken from Pual Ridge vent fluids with consistently high measured Mg concentrations (Table 5.1) strongly suggests that fluids there have mixed with seawater prior to exiting at the seafloor. Mixing of seawater and hydrothermal fluids prior to venting has been recognized ever since hydrothermal activity was first discovered in 1977 at the Galapagos Spreading Center (Corliss et al., 1979; Edmond et al., 1979a,b; Butterfield and Massoth, 1994; Edmond et al., 1995; Tivey et al., 1995; Gamo et al., 1996b; Von Damm et al., 1998; Gallant and Von Damm, 2006). The hypothesis that extensive subsurface mixing is responsible for much of the $\mathrm{Mg}$ in Pual Ridge fluids can be tested by examining the relationship between $\mathrm{Mg}$ abundance and temperature for co-located vents. Lines depicting conservation of specific enthalpy and $\mathrm{Mg}$ during mixing of $3^{\circ} \mathrm{C}$ seawater and the hottest endmember fluids at 
Roman Ruins and Fenway are shown in Figure 5.13. If other co-located fluids represent conservative mixtures of the hottest fluid and cold seawater they should fall on these mixing lines. Only fluids where at least 2 samples with consistent measured temperatures and $\mathrm{Mg}$ concentrations were collected are plotted to prevent ambiguity introduced by seawater contamination during sampling. Examination of Figure 5.13 reveals that the vents RMR4, RMR1 and RMR2 (Fig. 5.2b) display a clear conservative trend. At Fenway, the diffuse F5 vent appears to be a conservative mixture of seawater and the nearby F3 black smoker vent fluid. Vents RMR3, F2 and F4 fall below predicted temperatures, suggesting that in some cases conductive cooling may be occurring in addition to mixing. Temperature loss due to the former could explain the anomalously low apparent pressure of quartz-fluid equilibrium for F4 vent, and possibly other fluids also (Fig. 5.10). The agreement of measured temperatures and $\mathrm{Mg}$ concentrations with values predicted by the mixing model indicate a seawater source for the $\mathrm{Mg}$ in fluids and strongly suggests that entrained $\mathrm{Mg}$ behaves conservatively during mixing even at relatively high temperatures $\left(>250^{\circ} \mathrm{C}\right)$.

$\mathrm{SO}_{4}$ concentrations for the majority of PACMANUS fluids are lower than predicted for conservative mixing of seawater and an endmember hydrothermal fluid devoid of $\mathrm{Mg}$ and $\mathrm{SO}_{4}$ (Fig. 5.4), yielding apparent negative endmember $\mathrm{SO}_{4}$ concentrations at zero $\mathrm{Mg}$. This further confirms fluids are venting with non-zero $\mathrm{Mg}$ concentrations and near zero $\mathrm{SO}_{4}$, consistent with non-conservative behavior of $\mathrm{SO}_{4}$ relative to $\mathrm{Mg}$ during the mixing process. This behavior increases with the extent of mixing in most cases (Fig. 5.4) and fluids with higher $\mathrm{Mg}$ concentrations yield lower endmember $\mathrm{Ca} / \mathrm{Cl}$ and $\mathrm{Sr} / \mathrm{Cl}$ ratios upon extrapolation to zero $\mathrm{Mg}$ (Fig. 5.14a and 5.14b). Collectively, these data indicate anhydrite precipitation is occurring during mixing in response to its low solubility at elevated temperatures, thereby removing $\mathrm{Ca}$ (and coprecipitating $\mathrm{Sr}$ ) and seawater-derived $\mathrm{SO}_{4}$ (Mottl and Holland, 1978; Shikazono and Holland, 
1983; Berndt et al., 1988; Mills and Tivey, 1999). While unmixed hydrothermal fluid compositions can supply $\mathrm{Sr}$ in addition to that available in entrained seawater, in some cases losses are so great that $\mathrm{Sr}$ is also removed from the latter. Extrapolation of the SC1 fluid composition to zero $\mathrm{Mg}$ yields an apparent negative endmember $\mathrm{Sr}$ concentration and a near zero Ca concentration (Table 5.2). Such extreme $\mathrm{Sr}$ loss relative to $\mathrm{Mg}$ upon mixing provides and explanation for the implausible endmember ${ }^{87} \mathrm{Sr} /{ }^{86} \mathrm{Sr}$ ratio calculated at Snowcap (0.69768) which is beyond the range possible for crustal materials (Fig. 5.8; Banner, 2004).

In some cases, variable anhydrite precipitation is evident in multiple fluids sampled in close proximity to one another (e.g. RGR1 and RGR2 at Roger's Ruins, Figs. 5.2b and 5.4), suggesting that deposition may be occurring very near the seafloor or within sulfide structures themselves. Although mixing through 'leaky' walls of sulfide chimneys cannot be excluded at all vents (Haymon and Kastner, 1981; Goldfarb, 1983), consistently high Mg samples were collected from SM3 vent after the near complete removal of the sulfide chimney $(<1 \mathrm{~m}$ tall $)$ and measured fluid temperatures before $\left(279^{\circ} \mathrm{C}\right)$ and after removal $\left(280-288^{\circ} \mathrm{C}\right)$ were similar. This suggests that mixing occurred beneath the seafloor and not within the removed structure at SM3. Shallow subsurface precipitation of anhydrite is entirely consistent with observations from ODP drillcores which indicate that the abundant anhydrite deposits beneath the seafloor at PACMANUS contain seawater-derived $\mathrm{SO}_{4}$ (Roberts et al., 2003; Craddock, 2008). In cases where several vent fluids are in close proximity to one another and may be genetically related, the apparent variability in measured $\mathrm{Ca} / \mathrm{Cl}$ ratios due to anhydrite deposition is greatly reduced when such $\mathrm{Ca}$ loss is corrected. Using the deviations in measured $\mathrm{SO}_{4}$ concentrations from conservative behavior to estimate $\mathrm{SO}_{4}$ losses and assuming equimolar $\mathrm{Ca}$ loss for measured compositions, adjusted $\mathrm{Ca} / \mathrm{Cl}$ ratios in each case delineate trends between seawater and a much narrower range of endmember $\mathrm{Ca} / \mathrm{Cl}$ (Fig. 5.15). This suggest co-located vents at Roman Ruins, Roman Ruins and Fenway each 
reflect common source fluids that have undergone phase separation and partial segregation into fluids of differing $\mathrm{Cl}$ contents, followed by variable degrees of seawater entrainment into these fluids and concomitant anhydrite precipitation.

In addition to influence of mixing, some low temperature fluids at Pual Ridge, namely F5 vent and the NE Pual fluid (NP1), show evidence for extensive anhydrite dissolution and fixation of B. F5 vent $\left(80^{\circ} \mathrm{C}\right)$ was a poorly focused flow vent emanating from anhydrite sand/talus on the north flank of the Fenway mound (Fig. 5.2c). In addition to the temperature and proximity considerations above, endmember alkali/Cl ratios (Table 5.3, Fig. 5.11) at F5 are similar to those venting at the summit black smoker complex (F2, F3 and F4 vents), further suggesting the fluid is a mixture of the latter and seawater. The striking feature of F5 and NP1 compositions are measured $\mathrm{SO}_{4}$ concentrations (with near-seawater $\delta^{34} \mathrm{~S}_{\mathrm{SO} 4}$ values) that are elevated relative to concentrations predicted for conservative mixing of endmember fluids (devoid of $\mathrm{Mg}$ and $\mathrm{SO}_{4}$ ) and seawater (Fig. 5.4). In addition to high apparent endmember $\mathrm{Ca} / \mathrm{Cl}$ and $\mathrm{Sr} / \mathrm{Cl}$ ratios (Table 5.3, Fig. 5.14a and 5.14b), these differences indicate that previously precipitated anhydrite is being re-dissolved by F5 and NP1 fluids, a likely consequence of the relatively low temperatures $\left(<80^{\circ} \mathrm{C}\right)$ resulting from high degrees of mixing. Dissolution of anhydrite by active low temperature fluids has previously only been observed at $9^{\circ} 50^{\prime} \mathrm{N}$ on the East Pacific Rise (McDermott and Von Damm, 2008) and highlights the transient nature of $\mathrm{Ca}, \mathrm{Sr}$ and $\mathrm{SO}_{4}$ sinks in anhydrite. F5 and NP1 also differ from higher temperature Pual Ridge fluids in the behavior of B, as negative endmember concentrations are apparent upon extrapolation of measured B concentrations to zero $\mathrm{Mg}$ (Table 5.2). This implies removal of seawater-derived B in F5 and NP1 fluids in addition to the B complement of their parent hydrothermal fluids. The most plausible explanation for these depletions is that low temperature fixation reactions have decreased the abundances of B prior to venting. Laboratory and field studies have shown that 
fixation of B from seawater solutions occurs during low temperature $\left(<150^{\circ} \mathrm{C}\right)$ alteration of basaltic oceanic crust and likely sinks for B include alteration assemblages composed of ferric micas and smectites (Seyfried et al., 1984; Alt, 1995).

The pervasive nature of subsurface seawater entrainment apparent at Pual Ridge vent areas indicates a more open hydrologic regime beneath Pual Ridge compared to Vienna Woods and traditional MOR systems. Subsurface mixing at the TAG hydrothermal system was attributed to a 'leaky mound' model whereby seawater ingress is facilitated by the permeable anhydrite-sulfide breccia deposits of the TAG mound (Edmond et al., 1995; Humphris et al., 1995; Tivey et al., 1995; Humphris and Tivey, 2000). Aside from the Snowcap area, however, many of the mixed fluids at Pual Ridge are emanating from comparatively small sulfide structures atop rugged volcaniclastic flows. Meter-scale fissures were absent on the surface (Tivey et al., 2006), and it is possible fluid flow may instead be focused through contact zones between lava flows or subsurface networks of fractures/conduits (Binns et al., 2007). The possibility that the blocky, highly vesicular and brecciated volcaniclastic nature of lavas at Pual Ridge contributes to the mixing regime must also be considered. Monecke et al. (2007) demonstrated that hydrothermal alteration in glassy dacites from the surface of Pual Ridge is influenced by primary volcanic textures and that some fluid flow occurs through vesicles interconnected by perlitic cracks/quench fractures. Enhanced permeability and fluid flow due to volcanic textures has been suggested for other back-arc hydrothermal systems (Ishibashi and Urabe, 1995), and may be an inherent consequence of the volatile-rich nature of precursor magmas in these environments.

\subsubsection{Secondary Acidity}

An important consequence of the seawater entrainment and mixing beneath the seafloor at Pual Ridge is the deposition of iron sulfide minerals and production of secondary acidity in 
addition to that derived from magmatic fluid input at depth. Cooling induced by seawater mixing reduces the stability of iron chloride complexes and the solubility of iron sulfides, resulting in the removal of Fe from solution. Iron sulfide deposition can be described by the reactions:

$$
\begin{aligned}
& \mathrm{Fe}^{2+}+\mathrm{H}_{2} \mathrm{~S}_{(a q)}=\mathrm{FeS}_{(s)}+2 \mathrm{H}^{+} \\
& \mathrm{Fe}^{2+}+2 \mathrm{H}_{2} \mathrm{~S}_{(a q)}=\mathrm{FeS}_{2(s)}+2 \mathrm{H}^{+}+\mathrm{H}_{2(a q)} \\
& \mathrm{Cu}^{+}+\mathrm{Fe}^{2+}+2 \mathrm{H}_{2} \mathrm{~S}_{(a q)}=\mathrm{CuFeS}_{2(s)}+0.5 \mathrm{H}_{2(a q)}+3 \mathrm{H}^{+}
\end{aligned}
$$

All of these reactions result in the generation of acidity. Because of the higher Fe content (several $\mathrm{mmol} / \mathrm{kg}$ ) of Pual Ridge fluids relative to $\mathrm{Cu}(<1 \mathrm{mmol} / \mathrm{kg}$; Craddock, 2008), deposition of pyrrhotite $(\mathrm{FeS})$ or pyrite $\left(\mathrm{FeS}_{2}\right)$ will likely have a greater impact of fluid $\mathrm{pH}$ than chalcopyrite $\left(\mathrm{CuFeS}_{2}\right)$. The extent of Fe precipitation at PACMANUS can be qualitatively assessed by examining Fe/Mn ratios, since Fe precipitation from high temperature vent fluids during cooling is a relatively rapid process while Mn precipitation is kinetically inhibited (Seewald and Seyfried, 1990). Accordingly, initial Fe/Mn ratios of endmember hydrothermal fluids should decrease with increased cooling (due to mixing), potentially resulting in substantial secondary acidity generation according to reactions 3 to 5 . This is trend is observed for several PACMANUS vent areas, where both $\mathrm{pH}$ and endmember $\mathrm{Fe} / \mathrm{Mn}$ ratios are lower in fluids with higher measured $\mathrm{Mg}$ (Fig. 5.14c and 5.14d). These data suggest that differences in $\mathrm{pH}$ between co-located higher- and lower-temperature vent fluids reflect local modification by mixing-induced sulfide precipitation reactions that decrease $\mathrm{pH}$ below the already low values. The impact of these reactions is considerable given the extremely high Fe contents of Pual Ridge fluids.

The apparent lack of abundant disseminated pyrrhotite in either the ODP drillcores (Binns et al., 2007), or in chimney structures (Craddock, 2008), suggests that pyrite precipitation (reaction (4)) is responsible for Fe removal, which is consistent with the relatively oxidizing redox conditions (as indicated by the aqueous $\mathrm{H}_{2}$ concentrations) that fall at the low end of the 
spectrum for ridge-crest hydrothermal fluids (Seyfried and Ding, 1995b; Von Damm, 1995).

However, reaction (4) must produce equivalent moles of $\mathrm{H}_{2}$ for each mole of $\mathrm{Fe}$ deposited and $\mathrm{H}_{2}$ in Pual Ridge fluids does not approach the mmol/L levels expect for the quantities of Fe removal evident. Hence, an additional sink is required to consume $\mathrm{H}_{2}$. The only species present in sufficient quantities that is capable of oxidizing $\mathrm{H}_{2}$ in near-seafloor mixing zones is $\mathrm{SO}_{4}$, which is abundantly present in entrained seawater and as anhydrite. Reduction of $\mathrm{SO}_{4}$ by $\mathrm{H}_{2}$ can be represented by the reaction:

$$
\mathrm{HSO}_{4}^{-}+\mathrm{H}^{+}+4 \mathrm{H}_{2(a q)}=\mathrm{H}_{2} \mathrm{~S}_{(a q)}+4 \mathrm{H}_{2} \mathrm{O}_{(l)}
$$

That each mole of $\mathrm{SO}_{4}$ requires 4 moles of $\mathrm{H}_{2}$ for complete reduction indicates that reaction (6) might be an efficient sink for $\mathrm{H}_{2}$ generated by pyrite precipitation. Moreover, the kinetics of this reaction are greatly enhanced by the highly acidic nature of these fluids requiring timescales of a few hours to reach near-equilibrium states at $\mathrm{pH}$ and temperature conditions in subsurface environments (Ohmoto and Lasaga, 1982). In most cases, the decreases in $\mathrm{pH}$ observed for small amounts of seawater mixing are not as large as predicted from the apparent loss of Fe suggesting other reactions may be titrating secondary acidity generated by Fe-sulfide precipitation. This may reflect remobilization of other metals (e.g. $\mathrm{Zn}, \mathrm{Au}, \mathrm{Ag}$ and $\mathrm{Pb})$ and 'zone refinement'. Tivey et al. (1995) demonstrated that remobilization of metals was occurring as a direct result of modification of high temperature fluids by seawater entrainment within the TAG hydrothermal mound. 


\section{SUMMARY}

The concentrations of 23 dissolved species, in addition to select isotopic analyses, have been determined for 57 vent fluid samples collected from hydrothermal vent fields on the Manus Spreading Center (Vienna Woods) and Pual Ridge (PACMANUS and NE Pual) in the Manus back-arc basin. The sites differ substantially in both substrate type (mafic at Vienna Woods versus felsic at Pual Ridge) and proximity to the New Britain subduction zone (Pual Ridge is closest). Six areas of venting were sampled at PACMANUS, including a large area (Fenway) discovered during this expedition where vigorous 2-phase venting of $358^{\circ} \mathrm{C}$ fluid was observed, and one low temperature fluid was sampled at NE Pual. Distinct differences between the chemistries of fluids at Vienna Woods and Pual Ridge fluids indicate that while processes of water-rock interaction and phase separation are common to both, inputs of acidic magmatic fluids and entrainment of seawater into the subsurface exert substantial influence on high-temperature fluid chemistry at Pual Ridge.

All fluids at Vienna Woods are characterized by a high degree of uniformity and are compositionally similar to mid-ocean ridge basalt-hosted hydrothermal systems. Since the site was first sampled in 1990, the temperature and major element composition of fluids there have remained relatively constant. High absolute abundances and differing molar ratios of 'soluble' alkali elements and B in Pual Ridge fluids relative to those at Vienna Woods reflect hydrothermal interaction with the more arc-like crust of the Eastern Manus Volcanic Zone. Fluids from Pual

Ridge demonstrate $\mathrm{Cl}$ variability which, combined with trends of 'soluble' elements and dissolved gas abundances with $\mathrm{Cl}$, indicates that fluids have undergone phase separation even though measured exit temperatures for most vents are much lower than the 2-phase boundary for seawater. Vienna Woods are substantially cooler than the 2-phase boundary, hence either 
extensive conductive cooling must be occurring or the chronic venting of high $\mathrm{Cl}$ fluids there reflects residual brine entrainment.

Measured $\mathrm{pH}\left(25^{\circ} \mathrm{C}\right)$ values in low $\mathrm{Mg}$ fluids at Pual Ridge differ from those of Vienna Woods in that values are far lower than that expected for equilibrium buffering by host rock mineral assemblages, suggesting the involvement magmatic fluids with acid-volatile constituents (i.e. $\mathrm{SO}_{2}$ ). The extremely high dissolved metal contents and ubiquitous negative $\delta \mathrm{D}_{\mathrm{H} 2 \mathrm{O}}$ values found at PACMANUS are also consistent with the input of highly acidic magmatic fluids at depth to seawater-derived hydrothermal fluids. However, extremely high $\mathrm{CO}_{2}$ concentrations (up to $274 \mathrm{mmol} / \mathrm{kg}$ ) and negative $\delta^{34} \mathrm{~S}_{\mathrm{H} 2 \mathrm{~S}}$ values (down to $-2.7 \%$ ) - both of which are strongly indicative of magmatic inputs - are limited to Snowcap, Satanic Mills and Fenway vent areas. $\delta^{13} \mathrm{C}$ values of $\mathrm{CO}_{2}$ at PACMANUS are higher than those of Vienna Woods indicating a greater influence of slab-derived carbon at the former, which is located much closer to the active New Britain Arc.

The ubiquity of non-zero measured Mg concentrations in Pual Ridge fluids relative to Vienna Woods indicates that subsurface entrainment seawater into hydrothermal fluids during upflow is pervasive at the former and the various vent areas delineate a spectrum of subsurface mixing regimes. Trends of increasing non-conservative $\mathrm{SO}_{4}$ behavior, decreasing endmember $\mathrm{Ca} / \mathrm{Cl}$ and $\mathrm{Sr} / \mathrm{Cl}$ ratios with increased seawater admixing within vent areas demonstrate that subsurface precipitation of anhydrite is commonplace and is substantially modifying the Ca and Sr fluxes of high temperature fluids. Furthermore, these observations are accompanied in several cases by trends of decreasing endmember $\mathrm{Fe} / \mathrm{Mn}$ ratios and decreasing measured $\mathrm{pH}\left(25^{\circ} \mathrm{C}\right)$ with increasing Mg, implying that iron sulfide deposition is also occurring in the subsurface and is leading to secondary acidity production. 


\section{ACKNOWLEDGEMENTS}

This chapter represents a collaborative effort involving multiple researchers, including my primary advisor, Jeffrey Seewald. Peter Saccocia and Emily Walsh (Bridgewater State College) provided much needed assistance at sea in performing $\mathrm{pH}$ and $\mathrm{H}_{2} \mathrm{~S}$ analysis. W. Bach (University of Bremen) and M. Rosner (Freie Universität Berlin) performed Sr isotope analysis on collected fluids. P. Craddock performed $\mathrm{Fe}, \mathrm{Mn}, \mathrm{Li}, \mathrm{B}, \mathrm{Sr}, \mathrm{Rb}$ and $\mathrm{Cs}$ concentration analyses. W. C. Shanks (USGS) performed all $\mathrm{H}_{2} \mathrm{O}, \mathrm{H}_{2} \mathrm{~S}, \mathrm{SO}_{4}$ stable isotope analyses. Stable carbon isotope analyses were performed by $\mathrm{S}$. Sylva (WHOI). $\mathrm{SiO}_{2}$ data were provided by T. Pichler (University of Bremen). I am grateful to the crew of the $R / V$ Melville and ROV Jason II technical group for their expertise and assistance in successful completion of the dive program. I would also like to thank Maurice Tivey and the $A B E$ technical group for providing SM2000 bathymetric maps for the manuscript prior to submission. The manuscript benefited from numerous helpful discussions with Margaret K. Tivey before submission. This study received financial support from NSF grant OCE-0327448. 
Table 5.1.

Measured compositions of vent fluid samples from the Vienna Woods, PACMANUS and NE Pual vent fields, Manus Basin

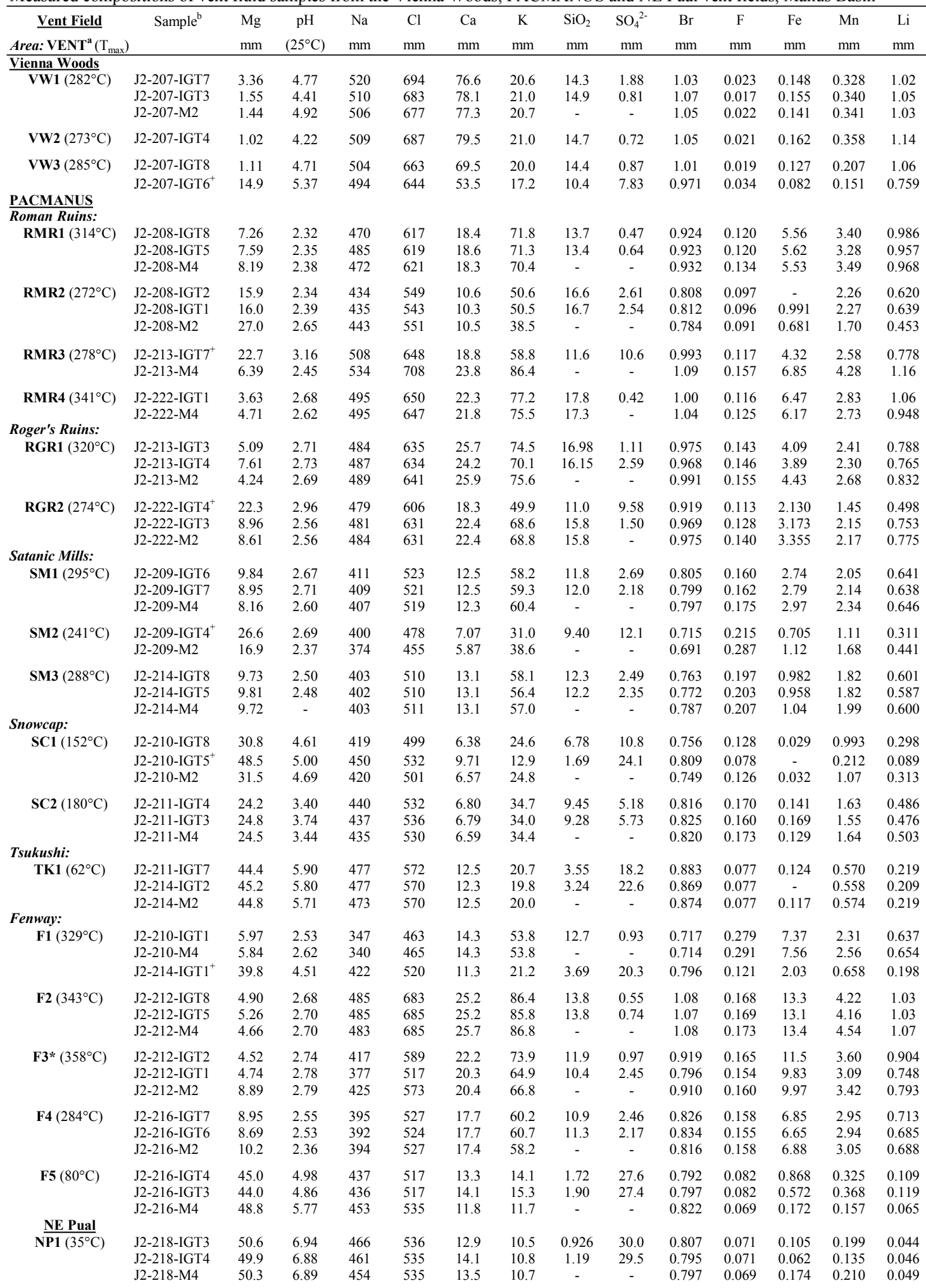

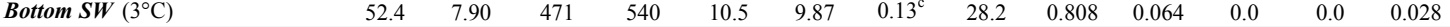
$\mathrm{mM}=\mathrm{mmol} / \mathrm{L}$ fluid, $\mathrm{mm}=\mathrm{mmol} / \mathrm{kg}$ fluid, $\mu \mathrm{m}=\mu \mathrm{mol} / \mathrm{kg}$ fluid, $\mu \mathrm{M}=\mu \mathrm{mol} / \mathrm{L}$ fluid. "-" = not determined. *Vigorous 2-phase venting. +Substantial SW entrainment suspected based on temperature monitoring. a. Each vent represents an individual orifice from which multiple samples were taken $\left(T_{\max }=\max\right.$. observed vent

temperature). b. Samples named by Jason (J2) dive number and gas-tight (-IGT) or major (-M) sampler number. c. Sarmiento and Gruber (2006) d. Spencer et al. (1970) e. Craig (1970) f. Redfield and Friedman (1965) g. Craig and Gordon (1965). h. Rees et al.(1978). 
Table 5.1. (cont'd)

Measured compositions of vent fluid samples from the Vienna Woods, PACMANUS and NE Pual vent fields, Manus Basin

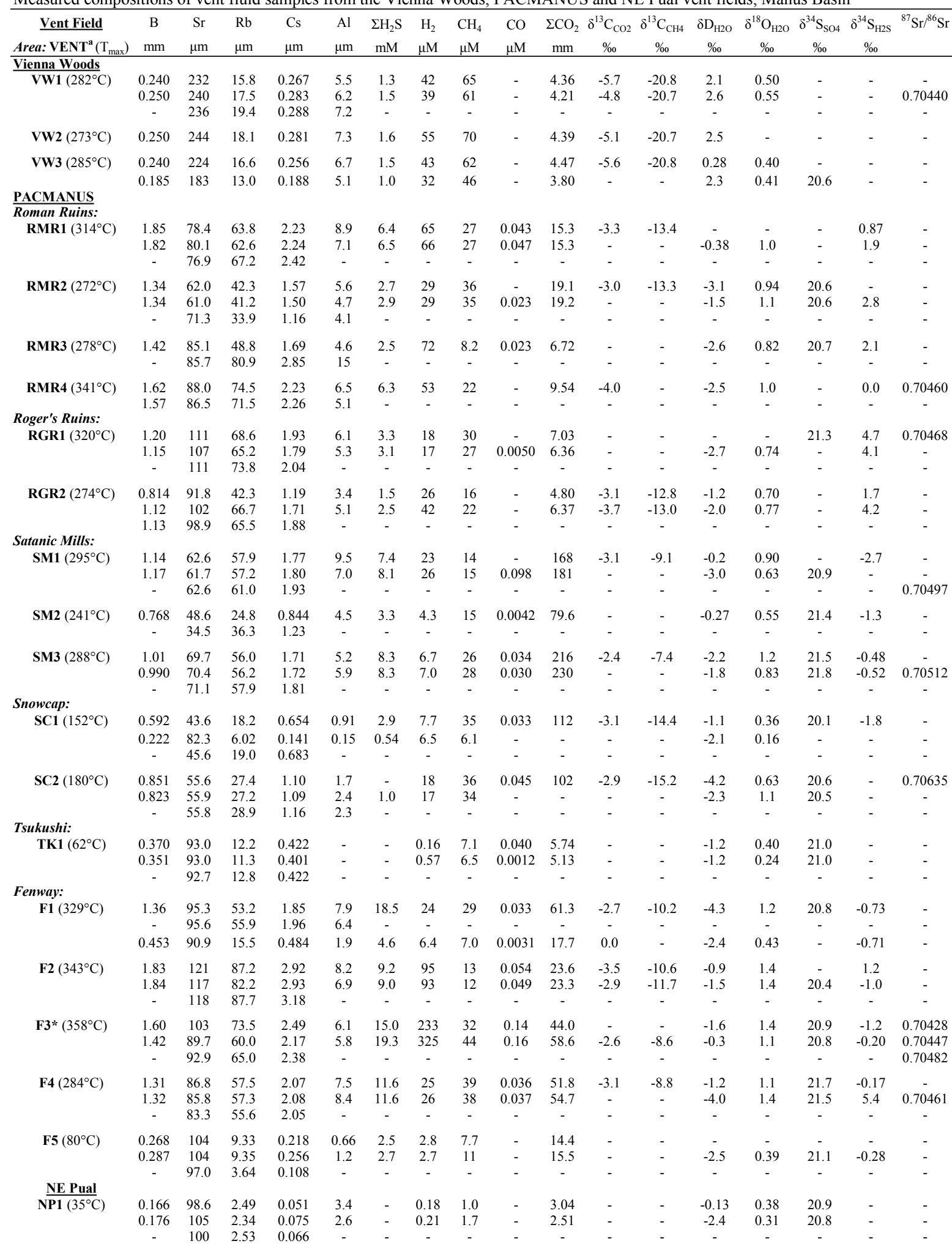

$\begin{array}{llllllllllllllllll}\text { Bottom } \boldsymbol{S W}\left(3^{\circ} \mathrm{C}\right) & 0.426 & 91.0 & 1.3^{\mathrm{d}} & 0.0023^{\mathrm{d}} & 0.0 & 0.0 & 0.0 & 0.0 & 0.0 & 2.3 & 0.3^{\mathrm{e}} & - & -0.14 \mathrm{f} & -0.17 \mathrm{~g} & 20.99 \mathrm{~h} & - & 0.70916\end{array}$ $\mathrm{mM}=\mathrm{mmol} / \mathrm{L}$ fluid, $\mathrm{mm}=\mathrm{mmol} / \mathrm{kg}$ fluid, $\mu \mathrm{m}=\mu \mathrm{mol} / \mathrm{kg}$ fluid, $\mu \mathrm{M}=\mu \mathrm{mol} / \mathrm{L}$ fluid. "-" = not determined. *Vigorous 2-phase venting. + Substantial SW entrainment suspected based on temperature monitoring. a. Each vent represents an individual orifice from which multiple samples were taken $\left(\mathrm{T}_{\max }=\max\right.$. observed vent temperature). b. Samples named by Jason (J2) dive number and gas-tight (-IGT) or major (-M) sampler number. c. Sarmiento and Gruber (2006) d. Spencer et al. (1970) e. Craig (1970) f. Redfield and Friedman (1965) g. Craig and Gordon (1965). h. Rees et al.(1978). 


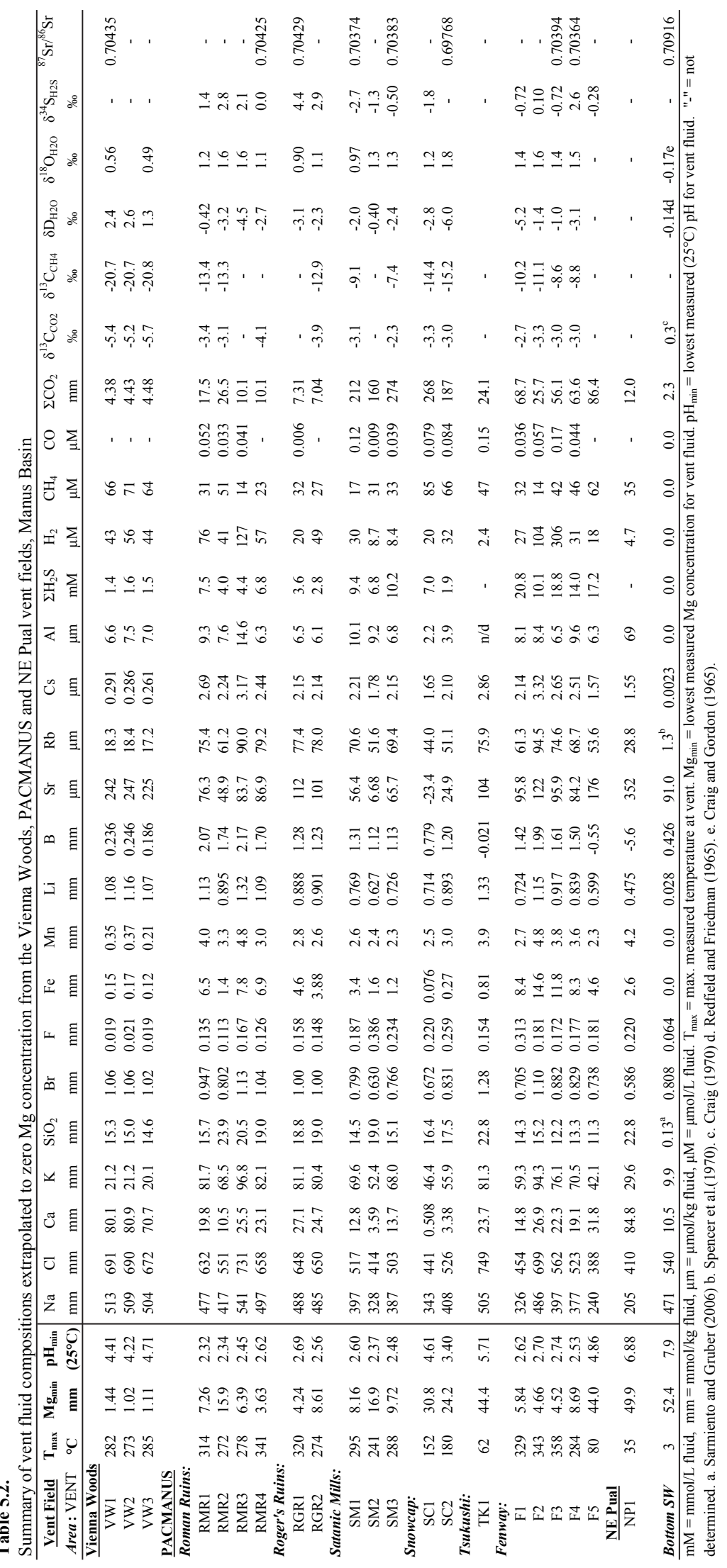


Table 5.3.

Selected elemental ratios at zero $\mathrm{Mg}$ concentration from the Vienna Woods, PACMANUS and NE Pual vent fields, Manus Basin

\begin{tabular}{|c|c|c|c|c|c|c|c|c|c|c|c|c|c|c|c|}
\hline$\frac{\text { Vent Field }}{\text { Area }: \text { Vent }}$ & $\begin{array}{c}\mathbf{T}_{\max } \\
{ }^{\circ} \mathbf{C}\end{array}$ & $\begin{array}{c}\mathbf{M g}_{\min } \\
\mathbf{m m}\end{array}$ & $\begin{array}{l}\mathbf{p H}_{\min } \\
\left(25^{\circ} \mathrm{C}\right)\end{array}$ & $\mathrm{Na} / \mathrm{Cl}$ & $\mathrm{Ca} / \mathrm{Cl}$ & $\mathrm{K} / \mathrm{Cl}$ & $\begin{array}{l}\mathrm{Sr} / \mathrm{Cl} \\
\times 10^{-3}\end{array}$ & $\begin{array}{l}\mathrm{Li} / \mathrm{Cl} \\
\times 10^{-3}\end{array}$ & $\begin{array}{l}\mathrm{Rb} / \mathrm{Cl} \\
\times 10^{-3}\end{array}$ & $\begin{array}{l}\mathrm{Cs} / \mathrm{Cl} \\
\times 10^{-6}\end{array}$ & $\begin{array}{l}\mathrm{Br} / \mathrm{Cl} \\
\times 10^{-3}\end{array}$ & $\begin{array}{l}\mathrm{B} / \mathrm{Cl} \\
\times 10^{-3}\end{array}$ & $\begin{array}{l}\mathrm{Fe} / \mathrm{Cl} \\
\times 10^{-3}\end{array}$ & $\begin{array}{l}\mathrm{Mn} / \mathrm{Cl} \\
\times 10^{-3}\end{array}$ & $\mathrm{Fe} / \mathrm{Mn}$ \\
\hline \multicolumn{16}{|c|}{ Vienna Woods } \\
\hline VW1 & 282 & 1.44 & 4.41 & 0.74 & 0.12 & 0.031 & 0.35 & 1.6 & 0.026 & 0.42 & 1.5 & 0.34 & 0.22 & 0.51 & 0.44 \\
\hline VW2 & 273 & 1.02 & 4.22 & 0.74 & 0.12 & 0.031 & 0.36 & 1.7 & 0.027 & 0.41 & 1.5 & 0.36 & 0.24 & 0.53 & 0.45 \\
\hline VW3 & 285 & 1.11 & 4.71 & 0.75 & 0.11 & 0.030 & 0.33 & 1.6 & 0.026 & 0.39 & 1.5 & 0.28 & 0.19 & 0.31 & 0.59 \\
\hline \multicolumn{16}{|c|}{ PACMANUS } \\
\hline \multicolumn{16}{|l|}{$\overline{\text { Roman Ruins: }}$} \\
\hline RMR1 & 314 & 7.26 & 2.32 & 0.75 & 0.031 & 0.13 & 0.12 & 1.8 & 0.12 & 4.3 & 1.5 & 3.3 & 10 & 6.3 & 1.6 \\
\hline RMR2 & 272 & 15.9 & 2.34 & 0.76 & 0.019 & 0.12 & 0.089 & 1.6 & 0.11 & 4.1 & 1.5 & 3.2 & 2.6 & 6.0 & 0.43 \\
\hline RMR3 & 278 & 6.39 & 2.45 & 0.74 & 0.035 & 0.13 & 0.11 & 1.8 & 0.12 & 4.3 & 1.5 & 3.0 & 11 & 6.5 & 1.6 \\
\hline RMR4 & 341 & 3.63 & 2.62 & 0.76 & 0.035 & 0.12 & 0.13 & 1.7 & 0.12 & 3.7 & 1.6 & 2.6 & 10 & 4.6 & 2.3 \\
\hline \multicolumn{16}{|c|}{ Roger's Ruins: } \\
\hline RGR1 & 320 & 4.24 & 2.69 & 0.75 & 0.042 & 0.13 & 0.17 & 1.4 & 0.12 & 3.3 & 1.5 & 2.0 & 7.2 & 4.3 & 1.7 \\
\hline RGR2 & 274 & 8.61 & 2.56 & 0.75 & 0.038 & 0.12 & 0.15 & 1.4 & 0.12 & 3.3 & 1.5 & 1.9 & 6.0 & 4.0 & 1.505 \\
\hline \multicolumn{16}{|l|}{ Satanic Mills: } \\
\hline SM1 & 295 & 8.16 & 2.60 & 0.77 & 0.025 & 0.13 & 0.11 & 1.5 & 0.14 & 4.3 & 1.5 & 2.5 & 6.6 & 5.1 & 1.3 \\
\hline SM2 & 241 & 16.9 & 2.37 & 0.79 & 0.0087 & 0.13 & 0.016 & 1.5 & 0.12 & 4.3 & 1.5 & 2.7 & 3.8 & 5.8 & 0.66 \\
\hline SM3 & 288 & 9.72 & 2.48 & 0.77 & 0.027 & 0.14 & 0.13 & 1.4 & 0.14 & 4.3 & 1.5 & 2.2 & 2.4 & 4.6 & 0.53 \\
\hline \multicolumn{16}{|l|}{ Snowcap: } \\
\hline $\mathrm{SC} 1$ & 152 & 30.8 & 4.61 & 0.78 & 0.0012 & 0.11 & -0.053 & 1.6 & 0.10 & 3.7 & 1.5 & 1.8 & 0.17 & 5.8 & 0.030 \\
\hline $\mathrm{SC} 2$ & 180 & 24.2 & 3.40 & 0.78 & 0.0064 & 0.11 & 0.047 & 1.7 & 0.097 & 4.0 & 1.6 & 2.3 & 0.52 & 5.7 & 0.091 \\
\hline \multicolumn{16}{|l|}{ Tsukushi: } \\
\hline $\begin{array}{r}\text { TK1 } \\
\text { Fenway: }\end{array}$ & \multicolumn{14}{|c|}{ Fenway: } & 0.21 \\
\hline $\mathrm{F} 1$ & 329 & 5.84 & 2.62 & 0.72 & 0.032 & 0.13 & 0.21 & 1.6 & 0.13 & 4.7 & 1.6 & 3.1 & 19 & 6.0 & 3.1 \\
\hline $\mathrm{F} 2$ & 343 & 4.66 & 2.70 & 0.69 & 0.039 & 0.13 & 0.17 & 1.6 & 0.14 & 4.8 & 1.6 & 2.8 & 21 & 6.8 & 3.1 \\
\hline F3 & 358 & 4.52 & 2.74 & 0.71 & 0.040 & 0.14 & 0.17 & 1.6 & 0.13 & 4.7 & 1.6 & 2.9 & 21 & 6.8 & 3.1 \\
\hline $\mathrm{F} 4$ & 284 & 8.69 & 2.53 & 0.72 & 0.037 & 0.13 & 0.16 & 1.6 & 0.13 & 4.8 & 1.6 & 2.9 & 16 & 6.9 & 2.3 \\
\hline F5 & 80 & 44.0 & 4.86 & 0.62 & 0.082 & 0.11 & 0.45 & 1.5 & 0.14 & 4.0 & 1.9 & -1.4 & 12 & 6.0 & 2.0 \\
\hline \multicolumn{16}{|l|}{ NE Pual } \\
\hline NP1 & 35 & 49.9 & 6.88 & 0.50 & 0.21 & 0.072 & 0.86 & 1.2 & 0.070 & 3.8 & 1.4 & -14 & 6.4 & 10 & 0.62 \\
\hline Bottom SW & 3 & 52.4 & 7.9 & 0.87 & 0.019 & 0.018 & 0.17 & 0.052 & 0.0024 & 0.0043 & 1.5 & 0.79 & $<0.001$ & $<0.001$ & - \\
\hline
\end{tabular}




\section{Figure 5.1.}

(a) Regional map showing the Manus Basin (eastern Bismarck Sea) and the locations (in light gray) of the Manus Spreading Center (MSC), Eastern Manus Volcanic Zone (EMVZ), major transform faults (TF) and known sites of hydrothermal activity. The Vienna Woods and PACMANUS sites are shown as stars (adapted from Craddock, 2008). The inactive Manus Trench is to the northeast. (b) SeaBeam bathymetric map of Pual Ridge and nearby Marmin Knolls neovolcanic edifices showing locations of the PACMANUS and Northeast (NE) Pual vent fields. Individual areas of venting are shown as circles (adapted from Tivey et al., 2006). 


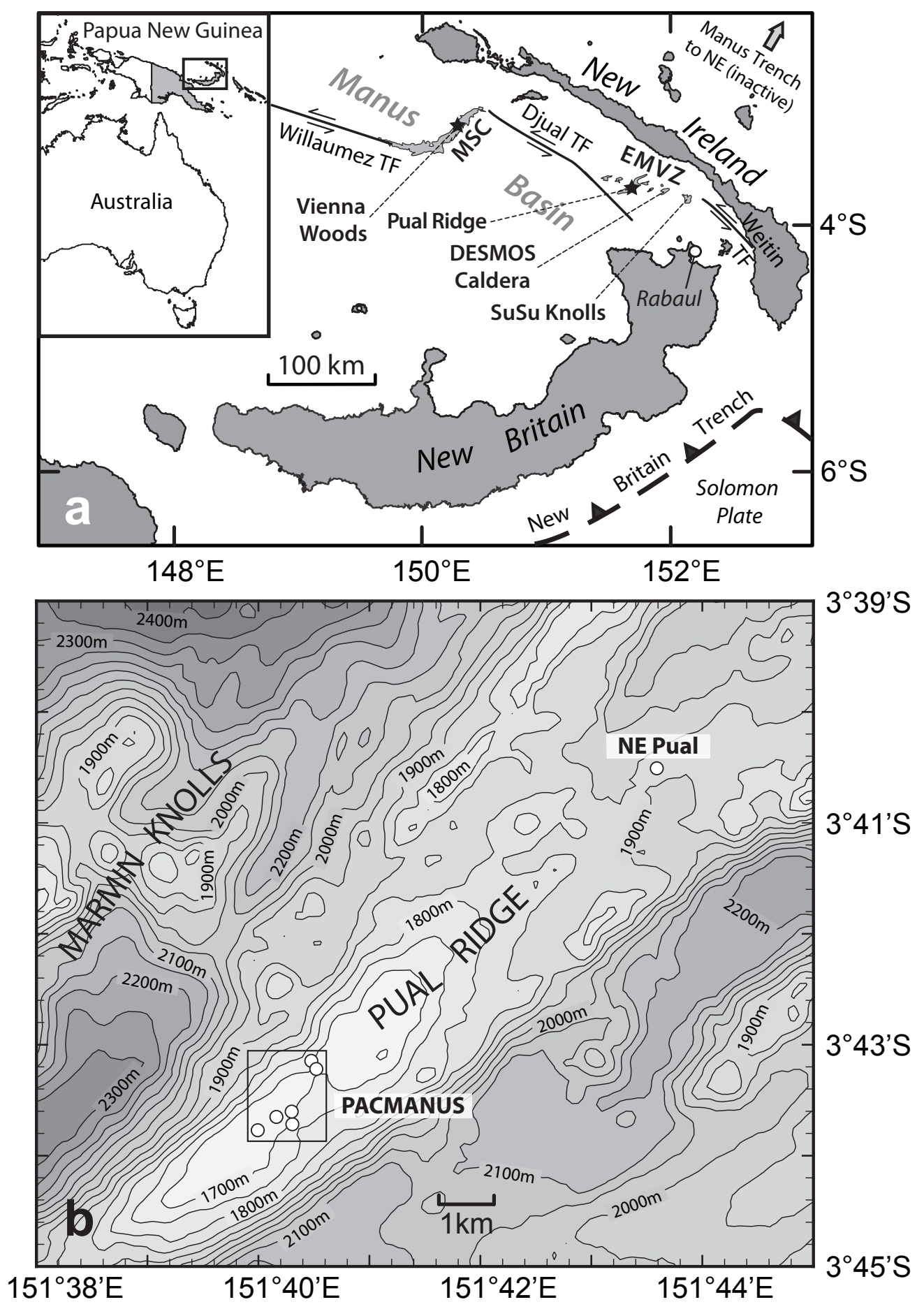

Figure 5.1. 


\section{Figure 5.2.}

SM2000 bathymetry of the Vienna Woods hydrothermal field (a) and the northern (b) and southern (c) portions of the PACMANUS hydrothermal field (adapted from Tivey et al., 2006). Sampled vents are denoted by solid triangles (moderate to high temperature focused flow), or open triangles (low temperature $\left(<80^{\circ} \mathrm{C}\right)$ vents). Each discrete vent is given an identifier abbreviating the vent area (VW = Vienna Woods; RMR = Roman Ruins; RGR = Roger's Ruins; $\mathrm{SM}=$ Satanic Mills; $\mathrm{SC}=$ Snowcap TK = Tsukushi; $\mathrm{F}=$ Fenway). Locations of the ODP Leg 193 drillholes (Sites 1188, 1189 and 1191) are shown as open circles. 

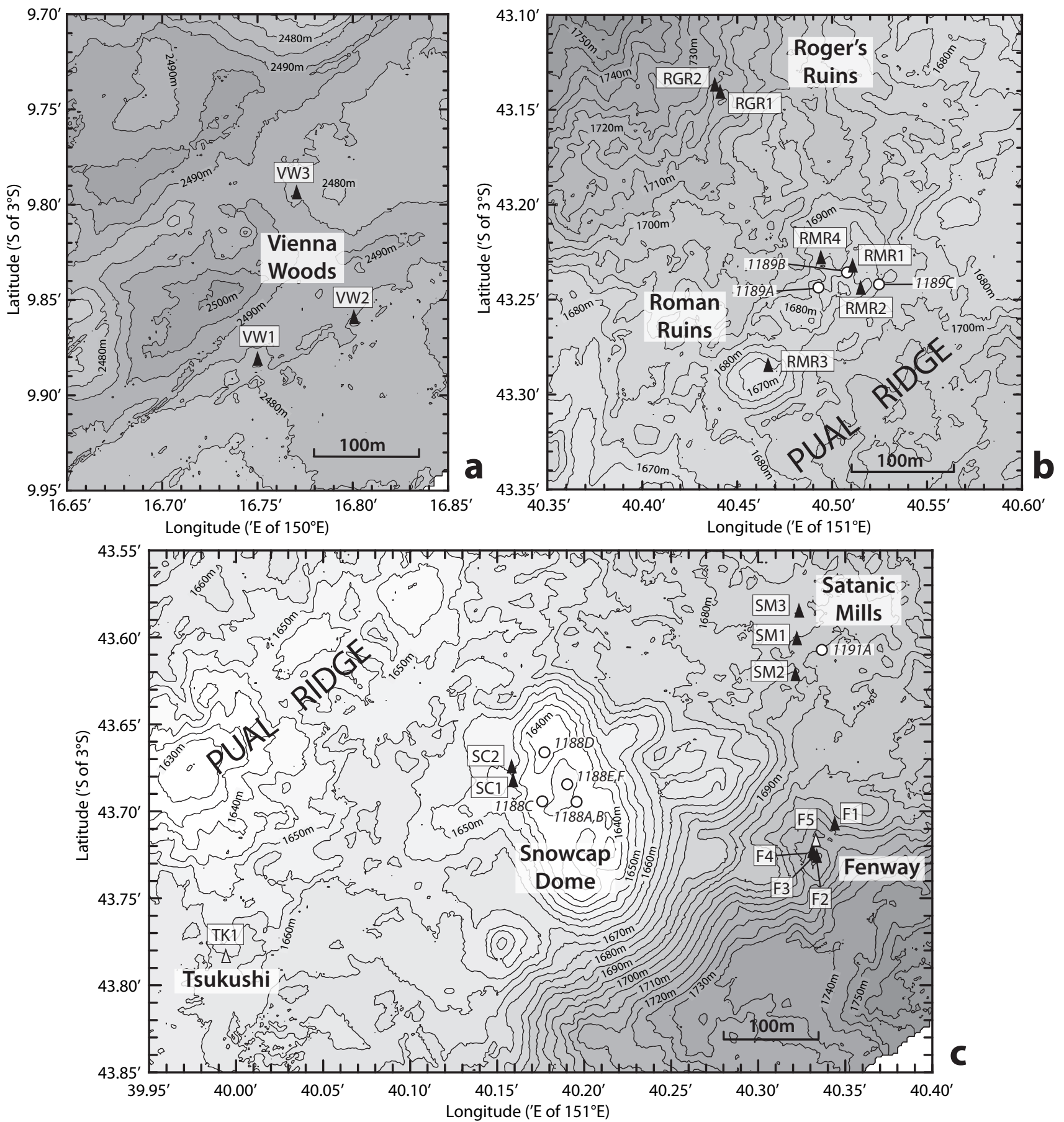

Figure 5.2. 


\section{Figure 5.3.}

Plot of vent pressures and maximum temperatures $\left(\mathrm{T}_{\max }\right)$ for all moderate- to high-temperature fluids sampled at Vienna Woods and PACMANUS. The black line represents the 2-phase boundary for a 3.2wt.\% NaCl solution (from Bischoff and Rosenbauer, 1985). Though $\mathrm{Cl}$ contents were highly variable between samples at F3 with similar $\mathrm{Mg}(517-589 \mathrm{mmol} / \mathrm{kg})$ due to the vigorously boiling nature of the fluid, using the endmember $\mathrm{Cl}$ value $(562 \mathrm{mmol} / \mathrm{kg})$ the fluid approximates a $\sim 3.3 \mathrm{wt} . \% \mathrm{NaCl}$ equivalent solution. 


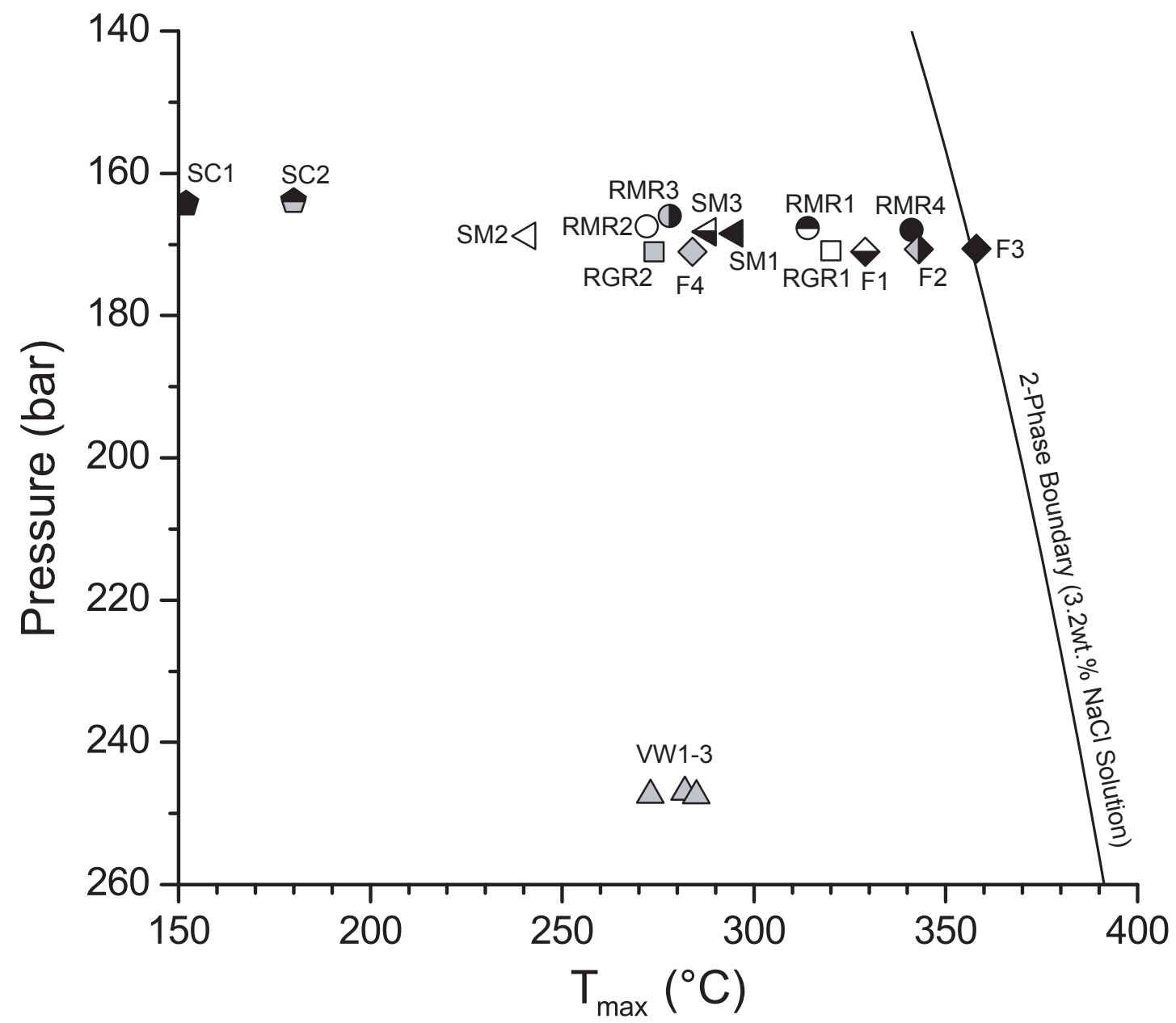

Figure 5.3. 
Figure 5.4.

Measured $\mathrm{SO}_{4}$ concentrations $v s$. measured $\mathrm{Mg}$ for all vent fluid samples from the Vienna Woods, PACMANUS and NE Pual fields. BSW is bottom seawater (denoted by star). 


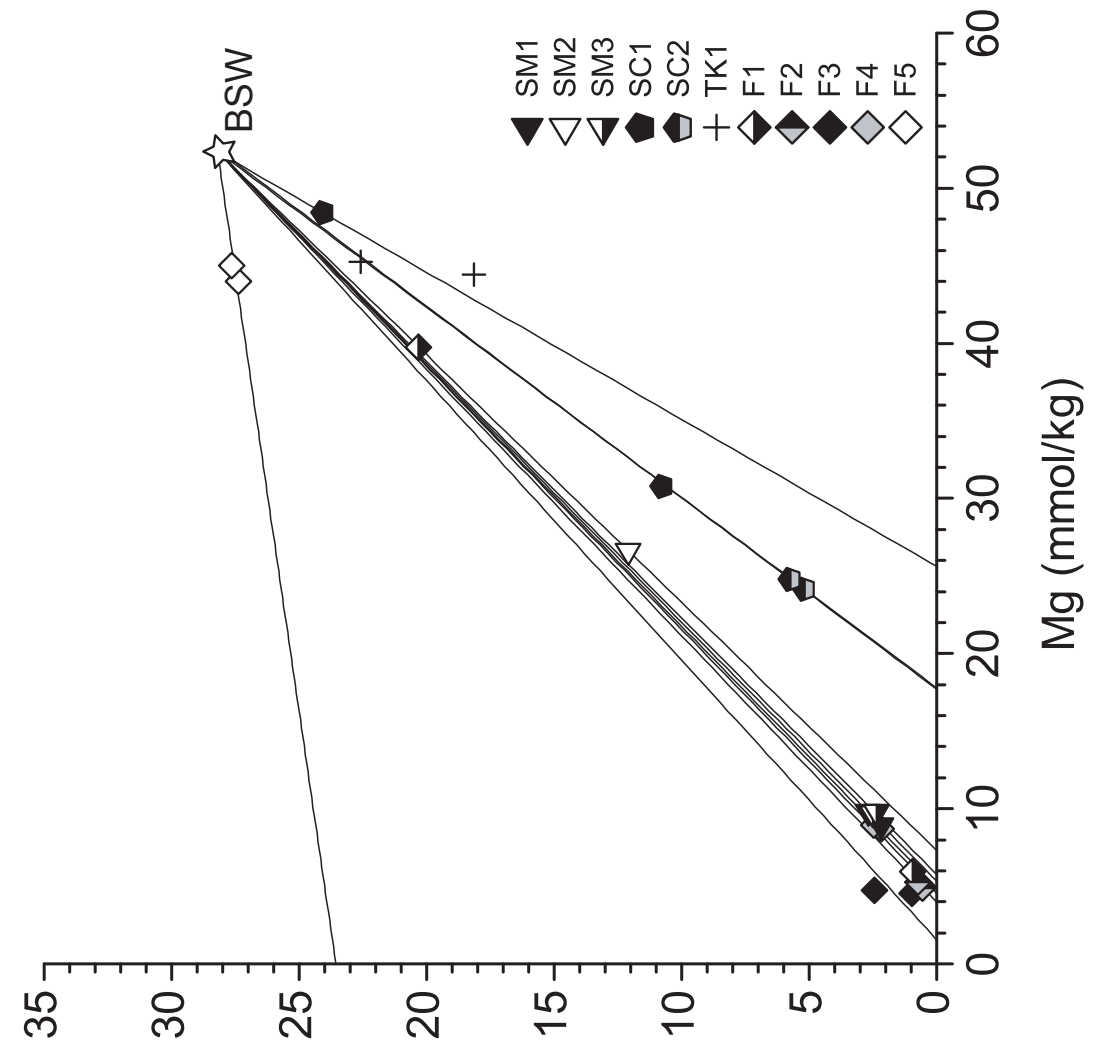

(6y/lomm) ${ }^{\triangleright}$ OS

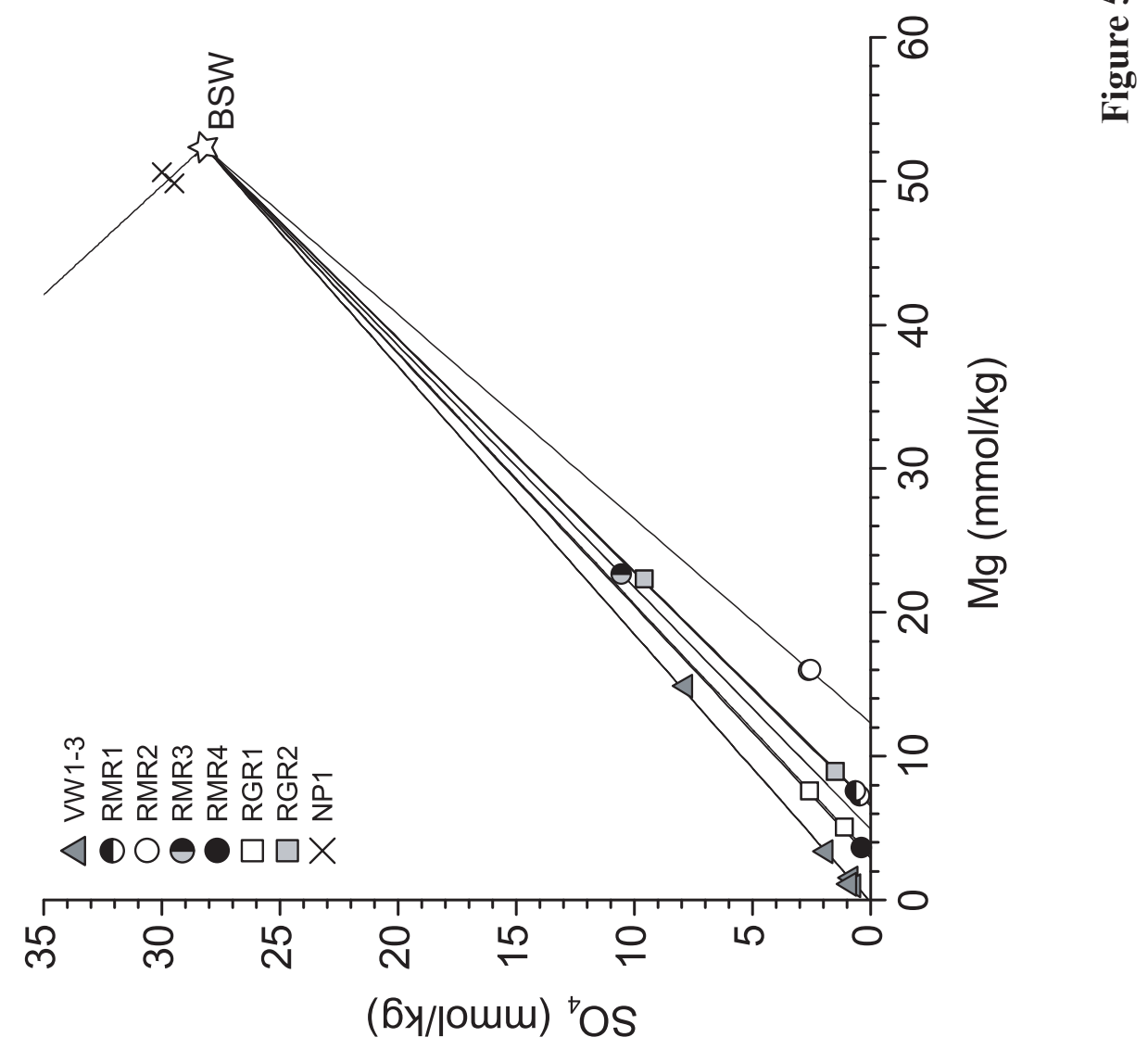


Figure 5.5. Endmember $\mathrm{H}_{2}$ (a), $\Sigma \mathrm{CO}_{2}$ (b), $\mathrm{H}_{2} \mathrm{~S}$ (c) and $\mathrm{CH}_{4}$ (d) concentrations vs. endmember $\mathrm{Cl}$ concentrations for all PACMANUS, NE Pual and Vienna Woods fluids. Dashed lines are drawn between closely co-located vents at Fenway, Snowcap, Roman Ruins and Roger's Ruins (cf. Fig. 2). BSW = Bottom Seawater. 

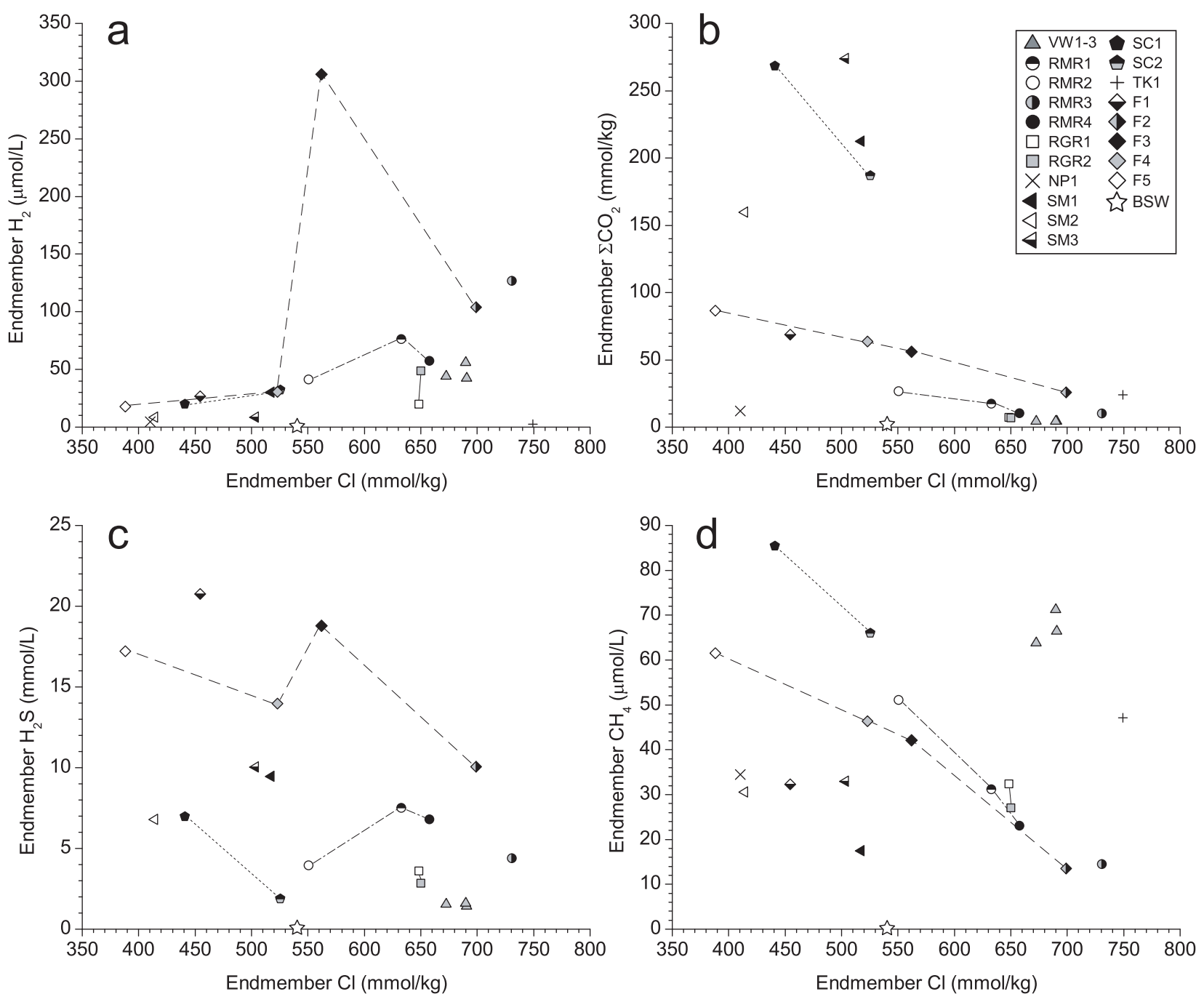

Figure 5.5. 
Figure 5.6.

Endmember $\Sigma \mathrm{CO}_{2}$ concentrations $v s$. endmember F concentration for all PACMANUS, NE Pual and Vienna Woods fluids. BSW $=$ Bottom Seawater. 


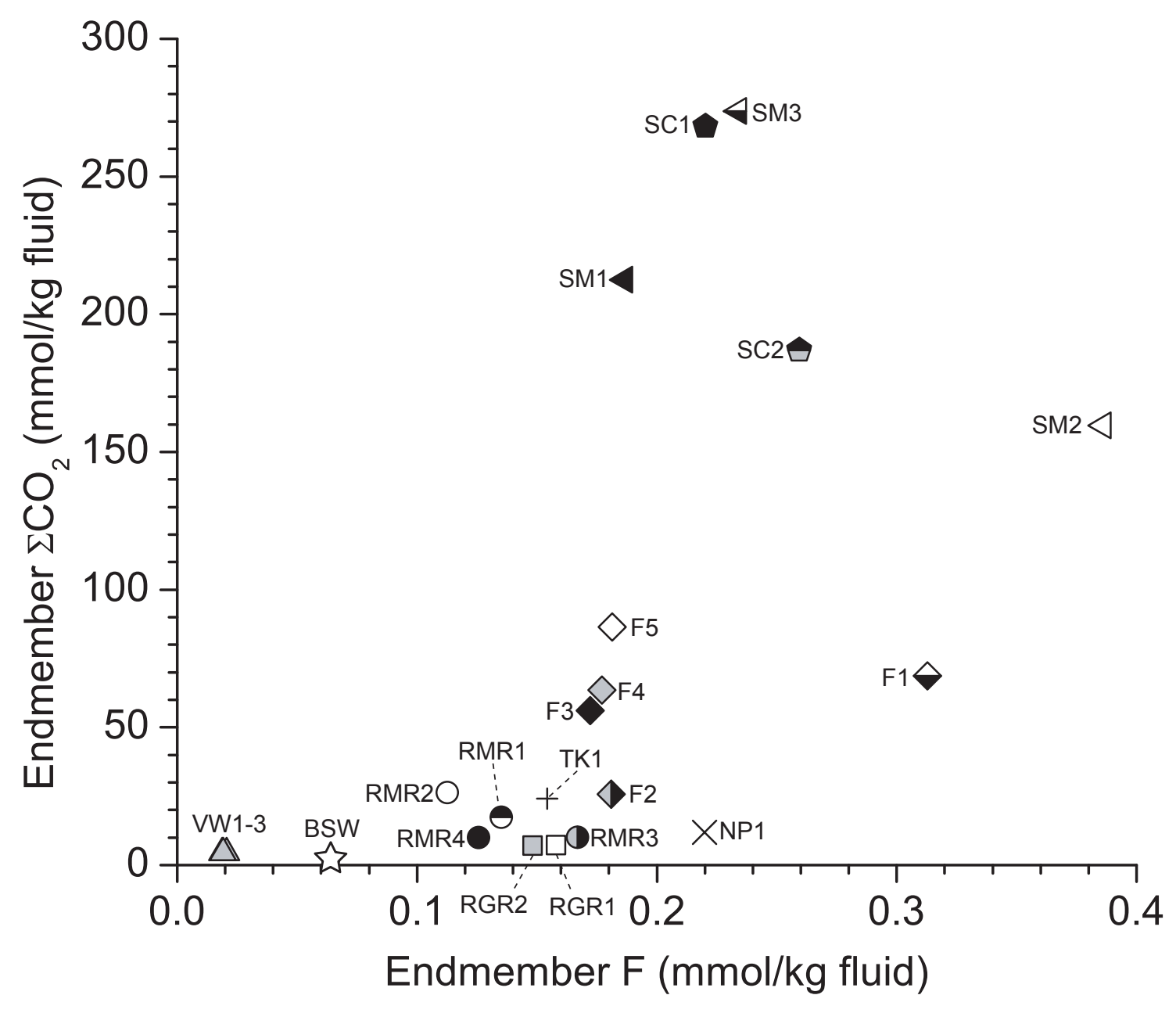

Figure 5.6. 


\section{Figure 5.7.}

Endmember $\delta \mathrm{D}_{\mathrm{H} 2 \mathrm{O}}$ and $\delta^{18} \mathrm{O}_{\mathrm{H} 2 \mathrm{O}}$ values from Vienna Woods and PACMANUS vent fields, with axes expanded to show compositions of mantle-derived water (MDW; Taylor, 1979b; Ohmoto, 1986) and subduction-related volcanic vapors (SRVV; Giggenbach, 1992; Hedenquist and Lowenstern, 1994). For clarity, the inset shows the data at a larger scale and 1s analytical errors. The isotopic composition of Pacific bottom seawater (SW) is shown by a star (Craig and Gordon, 1965; Redfield and Friedman, 1965). Fluids with near-SW Mg concentrations (F5, TK1 and NP1) are not plotted due to the large uncertainty associated with extrapolation of $\delta \mathrm{D}_{\mathrm{H} 2 \mathrm{O}}$ values to zero Mg. The solid black line represents a least squares regression of all PACMANUS and Vienna Woods isotopic compositions (excluding SW). This extrapolated trend strongly suggests a mixing scenario between SRVV compositions and an evolved SW-derived hydrothermal fluid (see text). 


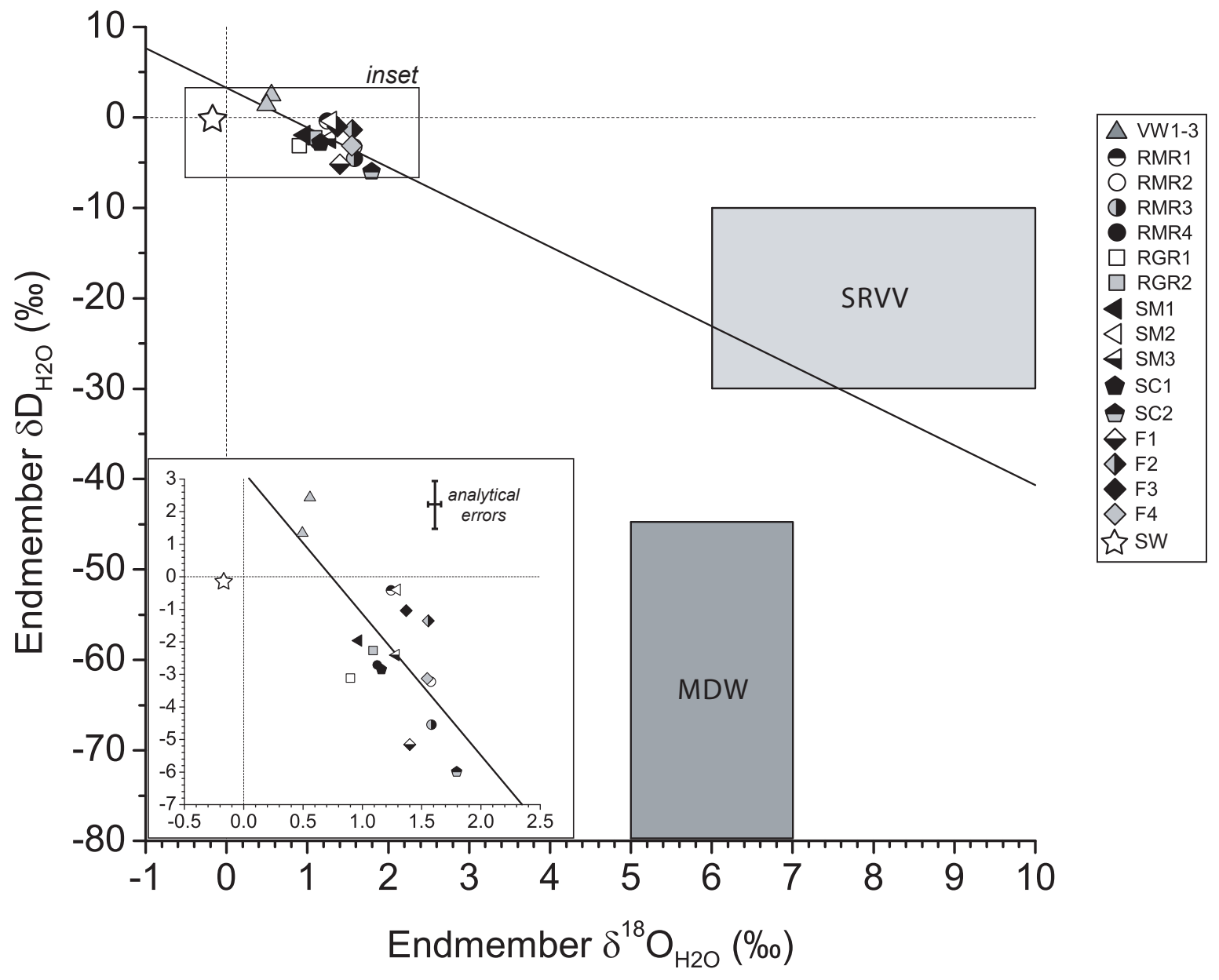

Figure 5.7. 


\section{Figure 5.8.}

Measured ${ }^{87} \mathrm{Sr} /{ }^{86} \mathrm{Sr}$ ratios versus measured $\mathrm{Mg} / \mathrm{Sr}$ ratios for select Vienna Woods and PACMANUS fluids. Lines of extrapolation from bottom seawater (BSW) to zero $\mathrm{Mg} / \mathrm{Sr}$ endmember ratios are shown (Albarède et al., 1981). The range of ${ }^{87} \mathrm{Sr} /{ }^{86} \mathrm{Sr}$ ratios for Pual Ridge/ EMVZ lavas (0.703446-0.703690, Kamenetsky et al., 2001; Marty et al., 2001) are shown by arrows, with Manus Spreading Center (MSC) basalt (0.703275, Sinton et al. 2003) lying just below this range. The $\mathrm{SC} 1$ vent fluid extrapolates to a ratio below that possible for modern terrestrial materials (Banner, 2004) - an artifact of high measured $\mathrm{Mg} / \mathrm{Sr}$ ratio. Sr loss due to coprecipitation in anhydrite is non-fractionating (Michard et al., 1984), and would increase measured $\mathrm{Mg} / \mathrm{Sr}$ without changing measured ${ }^{87} \mathrm{Sr} /{ }^{86} \mathrm{Sr}$. 


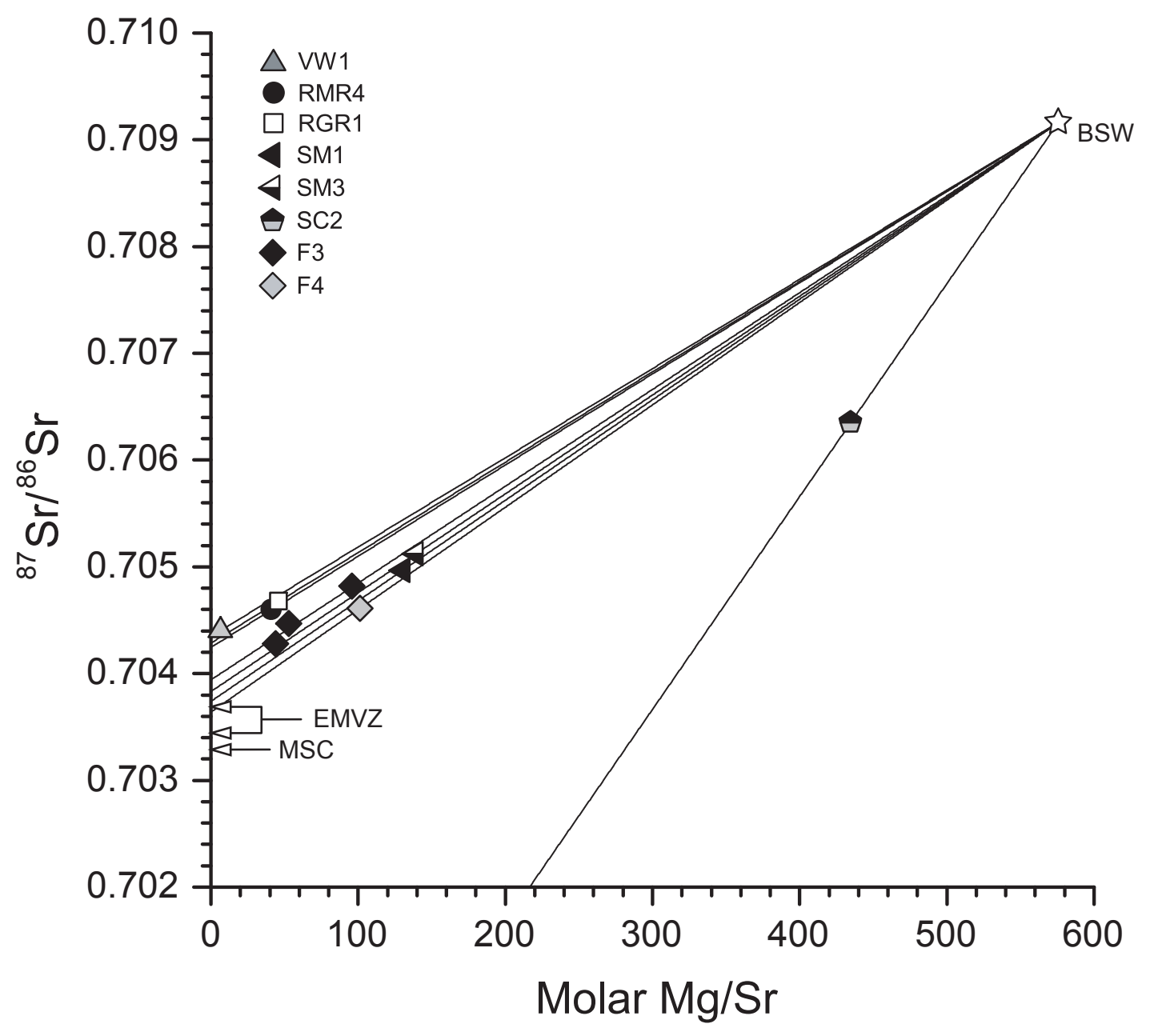

Figure 5.8. 


\section{Figure 5.9.}

Endmember K (A), Li (B) and Cs (C) concentrations vs. endmember Rb concentration for Vienna Woods, PACMANUS and NE Pual fluids. Light gray triangles refer to ranges of alkali/Rb ratios found in Manus Spreading Center (MSC) lavas (basalts and basaltic andesites), (Sinton et al., 2003). Dark gray triangles represent corresponding ranges for EMVZ (Sinton et al., 2003) and Pual Ridge (Kamenetsky et al., 2001) lavas. 

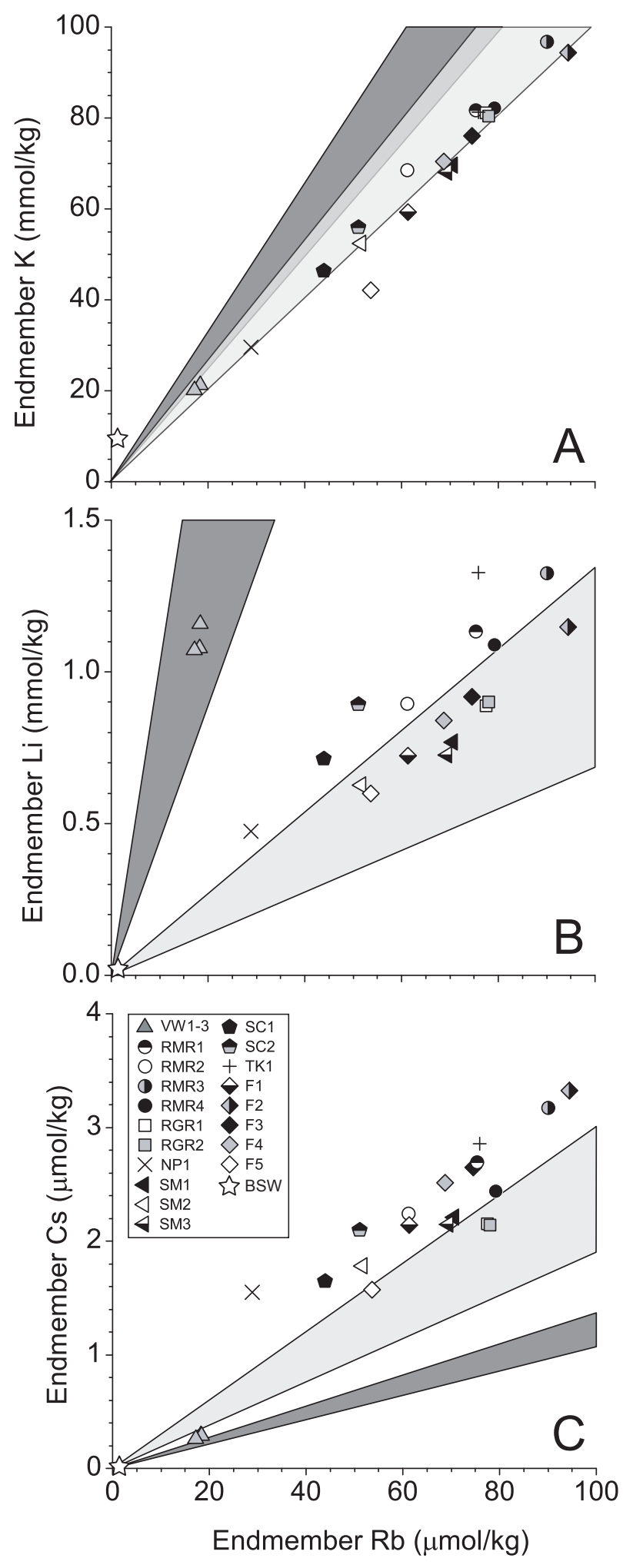

Figure 5.9. 


\section{Figure 5.10.}

Endmember $\mathrm{SiO}_{2}$ concentrations and extrapolated vent temperatures for Vienna Woods and PACMANUS fluids. The latter are calculated for vent fluids hotter than $\sim 270^{\circ} \mathrm{C}$ where consistent temperatures (within $10^{\circ} \mathrm{C}$ as measured by IGT samplers) and $\mathrm{Mg}$ concentrations were obtained in repeat samples of a given vent fluid. Temperatures were extrapolated (neglecting changes in heat capacity) to the estimated sampler dead volume contribution by linear regression forced through seawater. These calculations assume no conductive cooling occurred during mixing with seawater and neglect changes in heat capacity over the temperature range of extrapolation. Quartz saturation curves are shown for pressures of 100 to 1000 bar as a function of temperature (Von Damm et al., 1991). 


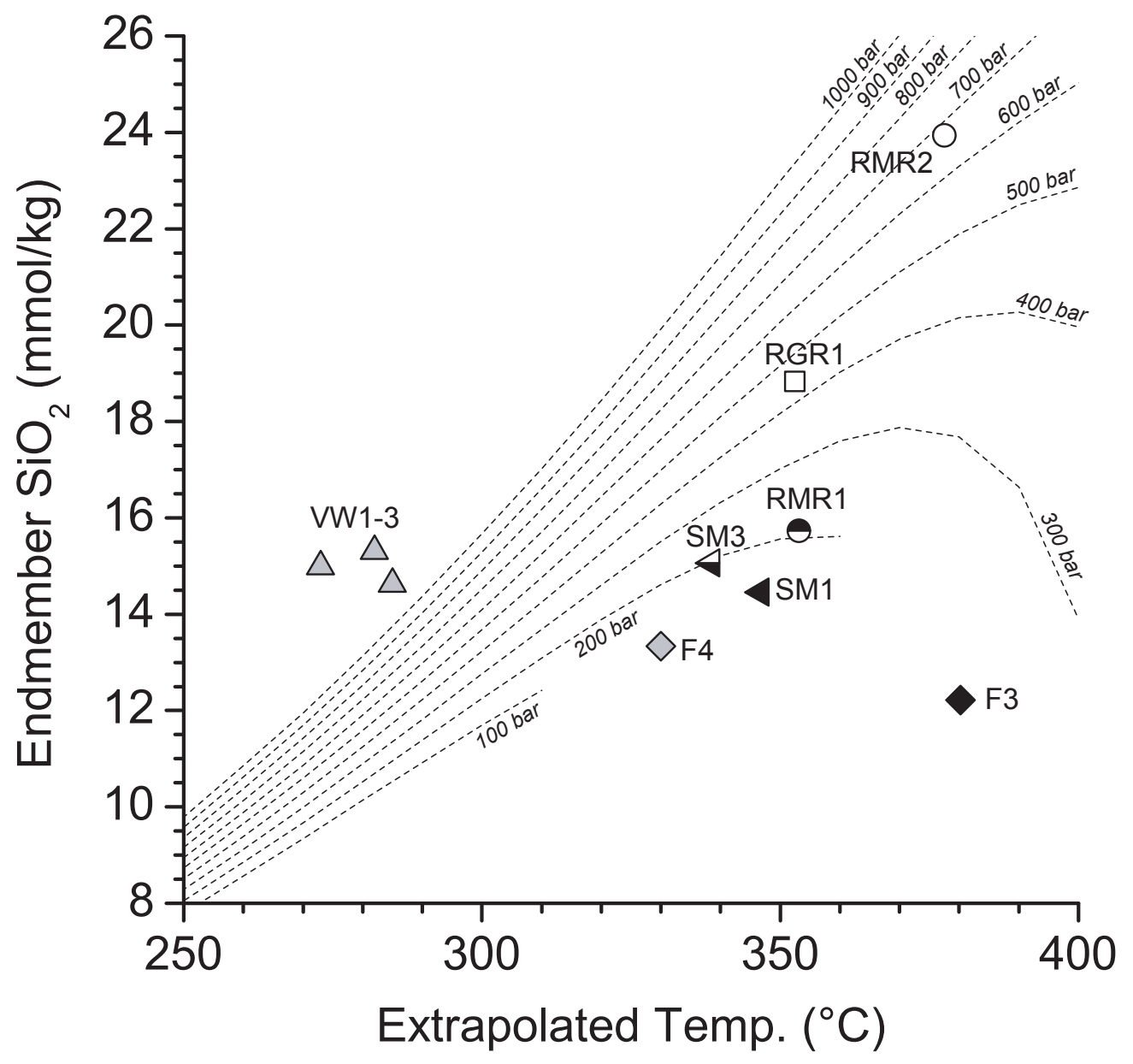

Figure 5.10. 


\section{Figure 5.11.}

Endmember Li (a), Rb (b), K (c) and Cs (d) concentrations vs. corresponding endmember $\mathrm{Cl}$ concentration for Vienna Woods, PACMANUS and NE Pual vent fluids. Solid (Satanic Mills), dashed (Fenway), dot-dashed (Roman Ruins) and dotted (Snowcap) lines represent unweighted linear least squared regressions of endmember fluid compositions within each respective vent area (limited to co-located vent fluids with largest degrees of intra-vent $\mathrm{Cl}$ variability). Colocated vent fluids (cf. Fig. 2) exhibit strong correlations with $\mathrm{Cl}$ which trend toward the origin, indicative of phase separation control and unmixing of high and low salinity fluid phases (Butterfield et al., 1994). BSW = bottom seawater. 

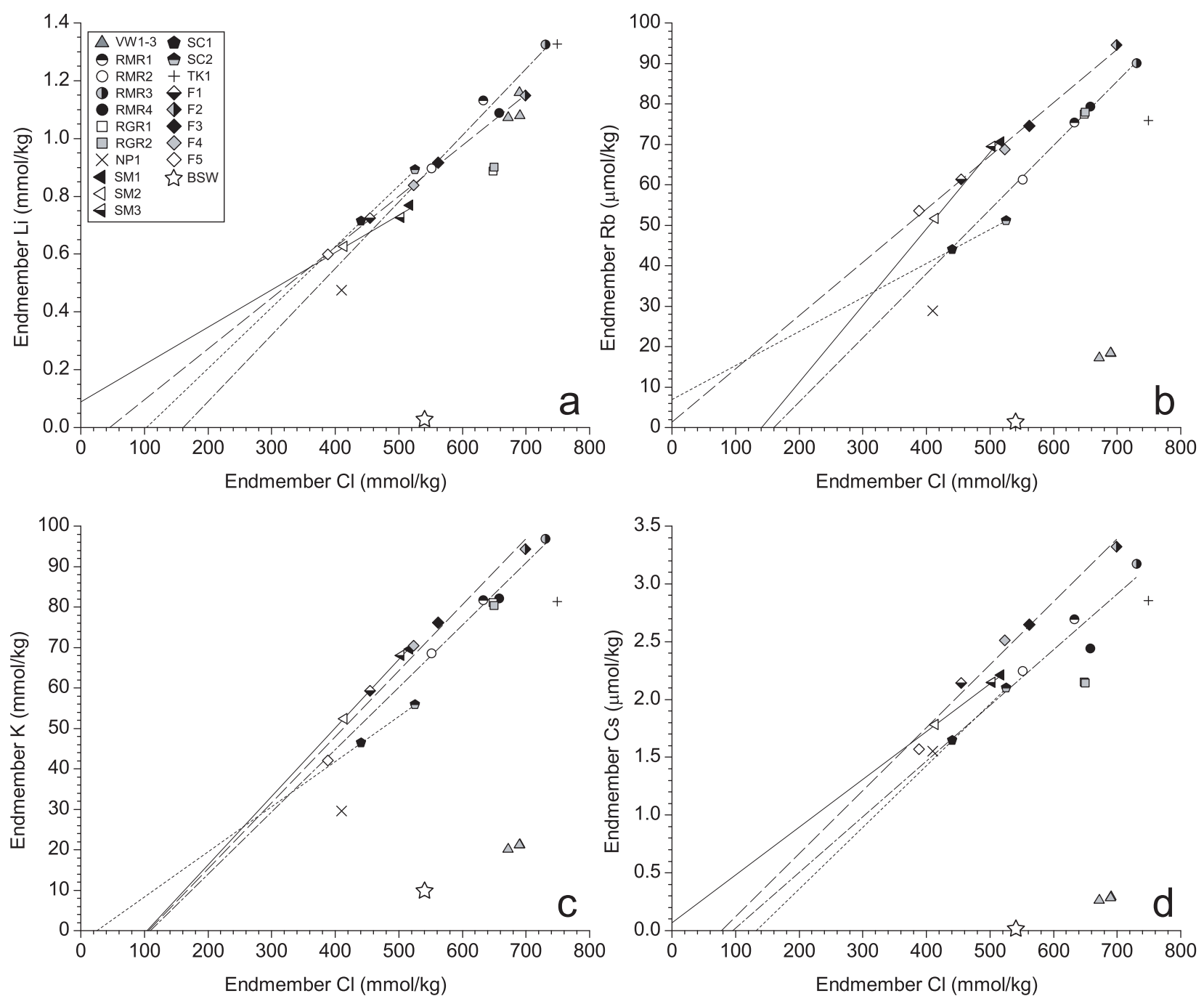

Figure 5.11. 
Figure 5.12.

$\delta^{34} \mathrm{~S}$ values for dissolved $\mathrm{H}_{2} \mathrm{~S}\left(\delta^{34} \mathrm{~S}_{\mathrm{H} 2 \mathrm{~S}}\right)$ versus endmember $\Sigma \mathrm{CO}_{2}$ concentrations. The range of $\delta^{34} \mathrm{~S}_{\mathrm{H} 2 \mathrm{~S}}$ values for unsedimented hydrothermal systems in MOR settings is $+1.4 \%$ o to $+8.6 \%$ (Shanks, 2001). Values from Pual Ridge fluids below this range are associated with higher $\mathrm{CO}_{2}$ concentrations of magmatic origin. 


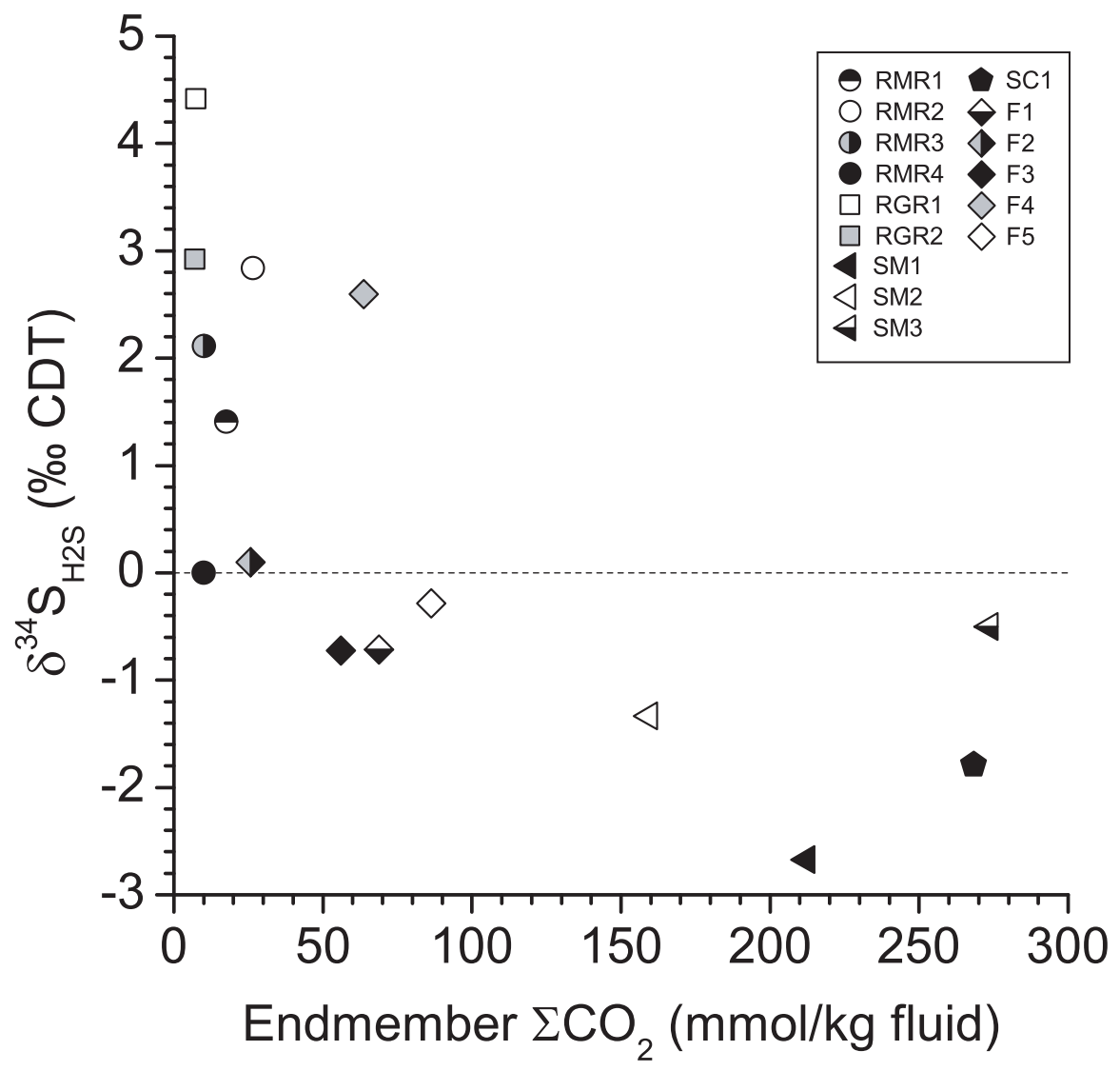

Figure 5.12. 


\section{Figure 5.13.}

Maximum measured vent temperatures $\left(\mathrm{T}_{\max }\right)$ for co-located vent fluids at Roman Ruins and Fenway versus their lowest measured $\mathrm{Mg}$ concentrations $\left(\mathrm{Mg}_{\min }\right)$. Only fluids where multiple samples yielded consistently high $\mathrm{Mg}$ concentrations and temperatures (within $10^{\circ} \mathrm{C}$ as measured by IGT samplers) are plotted (cf. Table 5.1). Mixing lines expected for conservative isenthalpic mixing between the vent fluids F3 (solid lines) and seawater, and RMR4 (dashed lines) and seawater are shown. Temperatures depicted by these mixing lines were calculated using the specific enthalpy data for a 3.2wt.\% NaCl solution at 200bar (Bischoff and Rosenbauer, 1985) and $\mathrm{Mg}$ concentrations are used as a conservative metric of mixing fraction between the hottest hydrothermal fluid and seawater compositions. The mixing lines assume a constant heat capacity for seawater below $200^{\circ} \mathrm{C}$ of $4.1 \mathrm{~J} / \mathrm{gK}$ (the actual change in heat capacity below $200^{\circ} \mathrm{C}$ is $<5 \%$ ). 


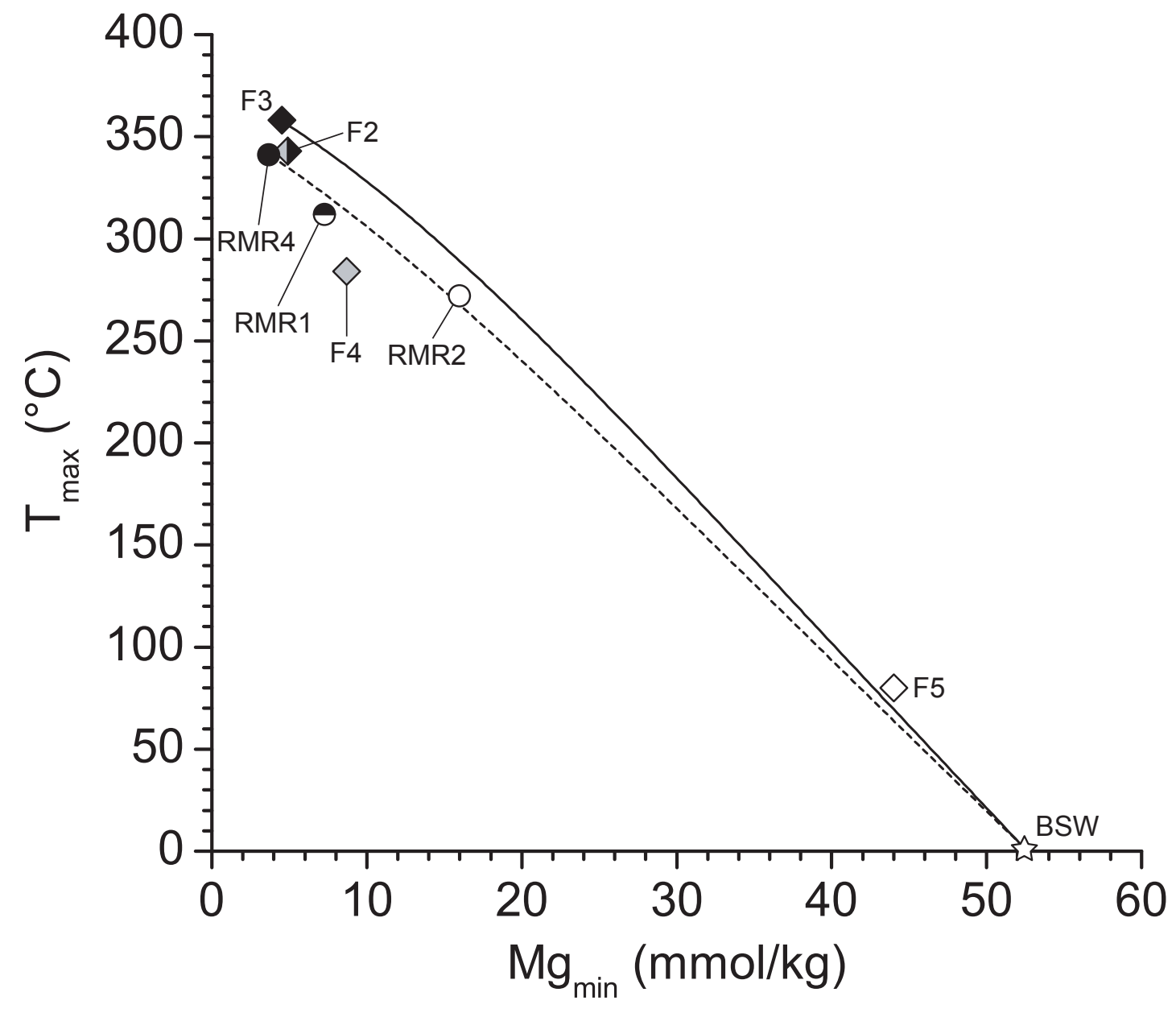

Figure 5.13. 


\section{Figure 5.14.}

Plots of (a) endmember $\mathrm{Ca} / \mathrm{Cl}$ ratios, (b) endmember $\mathrm{Sr} / \mathrm{Cl}$ ratios, (c) lowest measured fluid $\mathrm{pH}\left(25^{\circ} \mathrm{C}\right)$ and $(\mathbf{d})$ endmember $\mathrm{Fe} / \mathrm{Mn}$ ratios from Vienna Woods and Pual Ridge vent fluids $v s$. the lowest measured $\mathrm{Mg}$ concentration $\left(\mathrm{Mg}_{\min }\right)$ for each fluid. While these plots are unconventional, they are intended to show that at Pual Ridge, calculated endmember $\mathrm{Ca} / \mathrm{Cl}, \mathrm{Sr} / \mathrm{Cl}$ and $\mathrm{Fe} / \mathrm{Mn}$ ratios appear to decrease with increasing extents of seawater entrainment (accompanied by decreases in measured $\mathrm{pH}$ ) consistent with non-conservative behavior of $\mathrm{Ca}, \mathrm{Sr}$ and Fe. NP1, F5 and TK1 are anomalous in that they have high endmember $\mathrm{Ca} / \mathrm{Cl}$ and $\mathrm{Sr} / \mathrm{Cl}$ ratios. $\mathrm{BSW}=$ bottom seawater. 

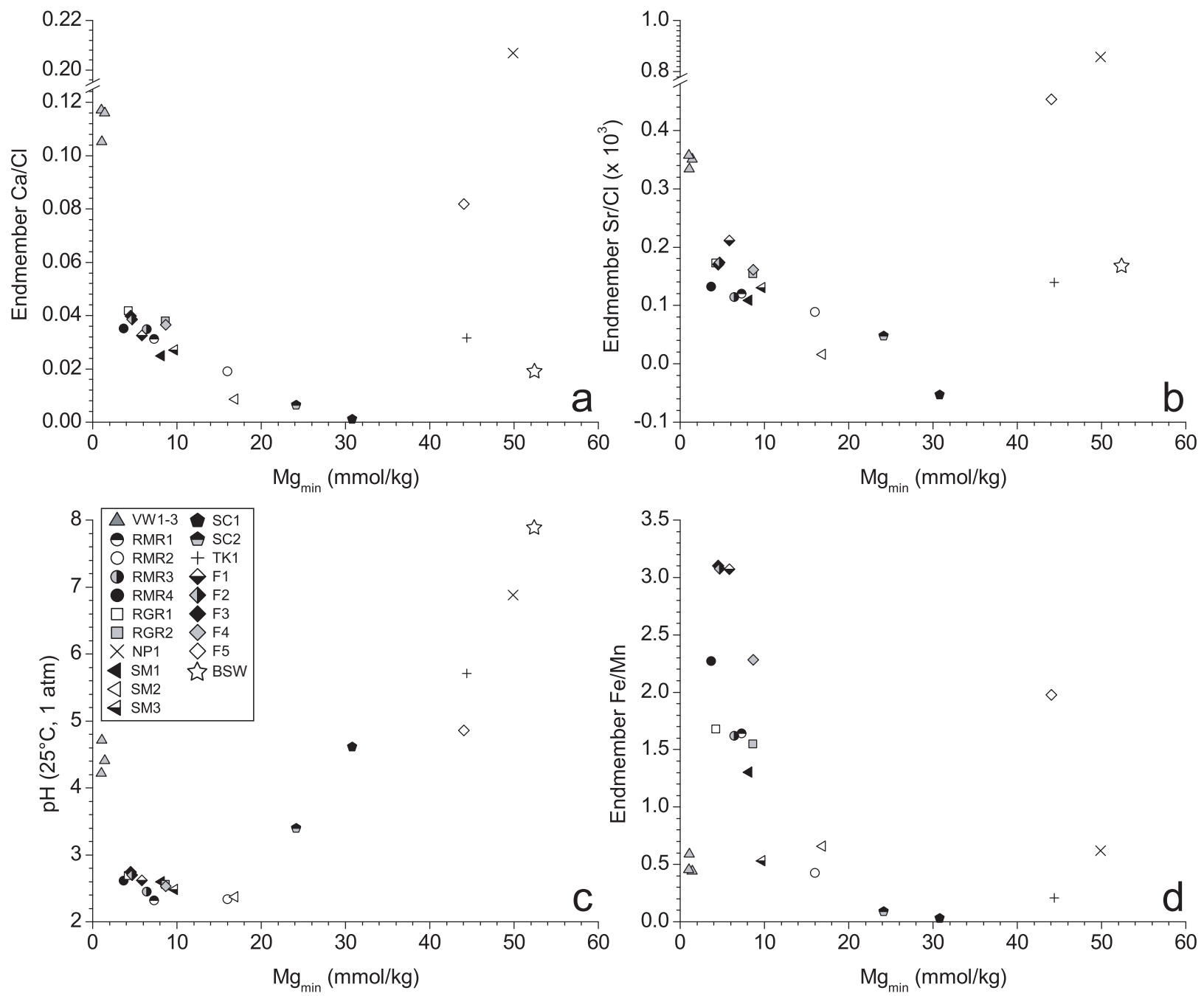

Figure 5.14. 


\section{Figure 5.15.}

Plot of measured molar $\mathrm{Ca} / \mathrm{Cl}$ ratios ("in situ") and corresponding "corrected" values (adjusted for anhydrite precipitation) versus lowest measured $\mathrm{Mg}$ concentrations $\left(\mathrm{Mg}_{\min }\right)$ for closely colocated PACMANUS vent fluids. The "in situ" symbols denote the $\mathrm{Ca} / \mathrm{Cl}$ of each fluid calculated at $\mathrm{Mg}_{\text {min }}$ from regressions of measured $\mathrm{Ca}$ and $\mathrm{Cl}$ concentrations. Deviations in the "in situ" $\mathrm{SO}_{4}$ concentration of these fluids (also calculated from measured $\mathrm{SO}_{4}{ }^{2-}$ regressions at $\mathrm{Mg}_{\min }$ ) from conservative mixing of a hypothetical zero $\mathrm{Mg}$, zero $\mathrm{SO}_{4}{ }^{2-}$ fluid are calculated and used to the correct the $\mathrm{Ca} / \mathrm{Cl}$ ratios for molar equivalent $\mathrm{Ca}$ loss (vertical arrows). Regression lines for each group of anhydrite "corrected" compositions (grouped by vent area) are shown. BSW= bottom seawater. 


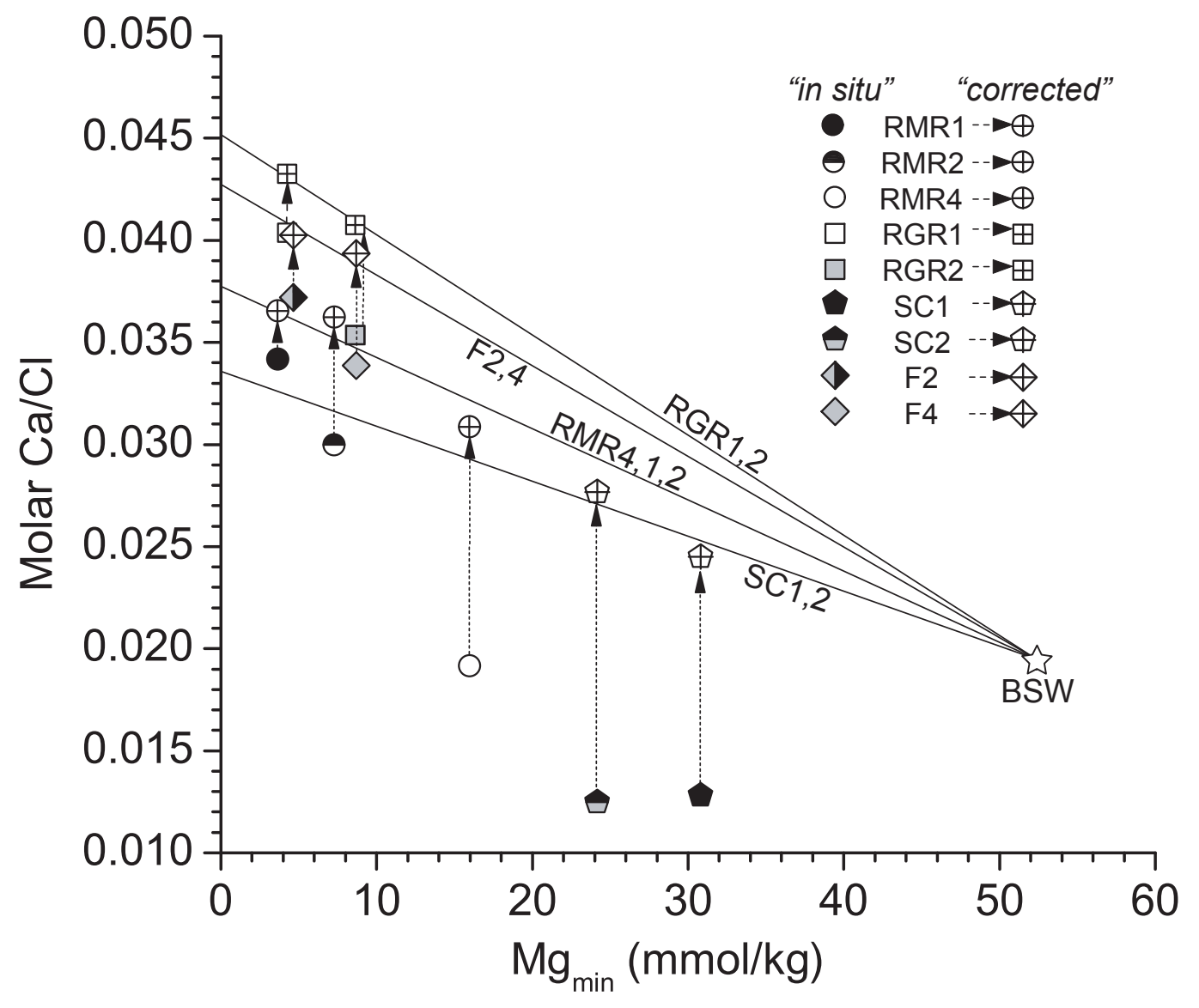

Figure 5.15. 


\section{REFERENCES}

Aiuppa, A., D. R. Baker, and J. D. Webster (2009) Halogens in volcanic systems. Chemical Geology 263(1-4), 1-18.

Albarède, F., A. Michard, J. F. Minster, and G. Michard (1981) ${ }^{87} \mathrm{Sr} /{ }^{86} \mathrm{Sr}$ ratios in hydrothermal waters and deposits from the East Pacific Rise at $21^{\circ}$ N. Earth and Planetary Science Letters 55, 229-236.

Alt, J. C. (1995) Subseafloor processes in mid-ocean ridge hydrothermal systems. In: Seafloor Hydrothermal Systems: Physical, Chemical, Biological, and Geological Interactions, AGU Monograph, (Ed: S. E. Humphris, R. A. Zierenberg, L. S. Mullineaux, and R. E. Thomson), AGU Mongraph, 91, American Geophysical Union. pp. 85-114.

Alt, J. and W. Bach (2003) Alteration of Ocean Crust. In: Dahlem Workshop Report: Energy and Mass Transfer in Marine Hydrothermal Systems, (Ed: P. E. Halbach, V. Tunnicliffe, and J. R. Hein), 89, Dahlem University Press. pp. 7-27.

Alt, J. C. and D. A. H. Teagle (1999) The uptake of carbon during alteration of ocean crust. Geochimica et Cosmochimica Acta 63(10), 1527-1535.

Arnorsson, S. and A. Andresdottir (1995) Processes controlling the distribution of boron and chlorine in natural waters in Iceland. Geochimica et Cosmochimica Acta 59(20), 41254146.

Arnorsson, S., K. Gronvold, and S. Sigurdsson (1978) Aquifer chemistry of four hightemperature geothermal systems in Iceland. Geochimica et Cosmochimica Acta 42(5), 523-536.

Audetat, A., D. Gunther, and C. A. Heinrich (1998) Formation of a magmatic-hydrothermal ore deposit: Insights with LA-ICP-MS analysis of fluid inclusions. Science 279(5359), 20912094. 
Auzende, J. M., T. Urabe, E. Ruellan, D. Chabroux, J. L. Charlou, K. Gena, T. Gamo, K. Henry, O. Matsubayashi, T. Matsumoto et al. (1996) "Shinkai 6500" Dives in the Manus Basin: New STARMER Japanese-French Program. JAMSTEC Journal of Deep Sea Research 12, 323-334.

Bach, W., S. Roberts, D. A. Vanko, R. A. Binns, C. J. Yeats, P. R. Craddock, and S. E. Humphris (2003) Controls of fluid chemistry and complexation on rare-earth element contents of anhydrite from the PACMANUS subseafloor hydrothermal system, Manus Basin, Papua New Guinea. Mineralium Deposita 38(8), 916-935.

Banner, J. L. (2004) Radiogenic isotopes: systematics and applications to earth surface processes and chemical stratigraphy. Earth-Science Reviews 65(3-4), 141-194.

Berndt, M. E. and W. E. Seyfried (1990) Boron, bromine, and other trace elements as clues to the fate of chlorine in mid-ocean ridge vent fluids. Geochimica et Cosmochimica Acta 54, $2235-2245$.

Berndt, M. E. and W. E. Seyfried (1993) Calcium and sodium exchange during hydrothermal alteration of calcic plagioclase at $400^{\circ} \mathrm{C}$ and 400 bars. Geochimica et Cosmochimica Acta 57(18), 4445-4451.

Berndt, M. E., W. E. Seyfried, and J. W. Beck (1988) Hydrothermal alteration processes at midocean ridges: experimental and theoretical constraints from $\mathrm{Ca}$ and $\mathrm{Sr}$ exchange reactions and Sr isotopic ratios. Journal of Geophysical Research 93(B5), 4573-4583.

Berndt, M. E., W. E. Seyfried, and D. R. Janecky (1989) Plagioclase and epidote buffering of cation ratios in mid-ocean ridge hydrothermal fluids - experimental results in and near the supercritical region. Geochimica et Cosmochimica Acta 53(9), 2283-2300. 
Berndt, M. E., R. R. Seal, W. C. Shanks, and W. E. Seyfried (1996) Hydrogen isotope systematics of phase separation in submarine hydrothermal systems: Experimental calibration and theoretical models. Geochimica et Cosmochimica Acta 60(9), 1595-1604.

Binns, R. A. and S. D. Scott (1993) Actively forming polymetallic sulfide deposits associated with felsic volcanic-rocks in the Eastern Manus Back-Arc Basin, Papua New Guinea. Economic Geology 88(8), 2226-2236.

Binns, R. A., S. D. Scott, J. B. Gemmell, K. Crook, and S. S. Party (1997) The SuSu Knolls Hydrothermal Field, Eastern Manus Basin, Papua New Guinea. EOS Trans. AGU, 78(722), Fall Meet. Suppl. V22E-02 (abstr.).

Binns, R. A., F. J. A. S. Barriga, and D. J. Miller (2007) Leg 193 Synthesis: Anatomy of an active felsic-hosted hydrothermal system, Eastern Manus Basin, Papua New Guinea. In: Proceedings of the Ocean Drilling Program, Scientific Results, (Ed: F. J. A. S. Barriga, R. A. Binns, D. J. Miller, and P. M. Herzig), 193, pp. 1-71.

Bischoff, J. L. and F. W. Dickson (1975) Seawater-basalt interaction at $200^{\circ} \mathrm{C}$ and 500 bars: Implications for origin of sea-floor heavy-metal deposits and regulation of seawater chemistry. Earth and Planetary Science Letters 25, 385-397.

Bischoff, J. L. and K. S. Pitzer (1985) Phase relations and adiabats in boiling seafloor geothermal systems. Earth and Planetary Science Letters 75(4), 327-338.

Bischoff, J. L. and R. J. Rosenbauer (1985) An empirical equation of state for hydrothermal seawater (3.2 percent $\mathrm{NaCl}$ ). American Journal of Science 285(8), 725-763.

Bischoff, J. L. and W. E. Seyfried (1978) Hydrothermal chemistry of seawater from 25 to $350^{\circ} \mathrm{C}$. American Journal of Science 278, 838-860. 
Both, R., K. Crook, B. Taylor, S. Brogan, B. Chappell, E. Frankel, L. Liu, J. Sinton, and D. Tiffin (1986) Hydrothermal chimneys and associated fauna in the Manus back-arc basin, Papua New Guinea. EOS Trans. AGU 67, 489-491.

Bowers, T. S. (1989) Stable isotope signatures of water-rock interaction in mid-ocean ridge hydrothermal systems: sulfur, oxygen and hydrogen. Journal of Geophysical Research 94(B5), 5775-5786.

Bowers, T. S. and H. P. Taylor (1985) An integrated chemical and stable-isotope model of the origin of midocean ridge hot spring systems. Journal of Geophysical Research 90(B14), 12583-12606.

Brimhall, G. H. and M. S. Ghiorso (1983) Origin and ore-forming consequences of the advanced argillic ateration process in hypogene environments by magmatic gas contamination of meteoric fluids. Economic Geology 78(1), 73-90.

Burnham, C. W. (1979) Magmas and hydrothermal fluids. In: Geochemistry of Hydrothermal Ore Deposits, (Ed: H. L. Barnes), Wiley. pp. 71-136.

Butterfield, D. A. and G. J. Massoth (1994) Geochemistry of North Cleft Segment vent fluids temporal changes in chlorinity and their possible relation to recent volcanism. Journal of Geophysical Research-Solid Earth 99(B3), 4951-4968.

Butterfield, D. A., G. J. Massoth, R. E. Mcduff, J. E. Lupton, and M. D. Lilley (1990) Geochemistry of hydrothermal fluids from Axial Seamount Hydrothermal Emissions Study vent field, Juan De Fuca Ridge: Subseafloor boiling and subsequent fluid-rock interaction. Journal of Geophysical Research-Solid Earth and Planets 95(B8), 12895 12921.

Butterfield, D. A., R. E. Mcduff, M. J. Mottl, M. D. Lilley, J. E. Lupton, and G. J. Massoth (1994) Gradients in the composition of hydrothermal fluids from the Endeavor Segment 
vent field: Phase separation and brine loss. Journal of Geophysical Research-Solid Earth 99(B5), 9561-9583.

Butterfield, D. A., I. R. Jonasson, G. J. Massoth, R. A. Feely, K. K. Roe, R. E. Embley, J. F. Holden, R. E. Mcduff, M. D. Lilley, and J. R. Delaney (1997) Seafloor eruptions and evolution of hydrothermal fluid chemistry. Philosophical Transactions of the Royal Society of London Series A-Mathematical Physical and Engineering Sciences 355(1723), 369-386.

Butterfield, D., W. E. Seyfried, and M. Lilley (2003) Composition and evolution of hydrothermal fluids. In: Dahlem Workshop Report: Energy and Mass Transfer in Marine Hydrothermal Systems, (Ed: P. E. Halbach, V. Tunnicliffe, and J. R. Hein), 89, Dahlem University Press. pp. 123-161.

Carroll, M. R. and M. J. Rutherford (1988) Sulfur speciation in hydrous experimental glasses of varying oxidation-state: Results from measured wavelength shifts of sulfur x-rays. American Mineralogist 73(7-8), 845-849.

Carroll, M. R. and J. D. Webster (1994) Solubilities of sulfur, noble gases, nitrogen, chlorine, and fluorine in magmas. In: Volatiles in magmas, (Ed: M. R. Carroll and J. R. Holloway), Reviews in Mineralogy, 30, Mineralogical Society of America. pp. 231-279.

Cartigny, P., N. Jendrzejewski, F. Pineau, E. Petit, and M. Javoy (2001) Volatile (C, N, Ar) variability in MORB and the respective roles of mantle source heterogeneity and degassing: the case of the Southwest Indian Ridge. Earth and Planetary Science Letters 194(1-2), 241-257.

Charlou, J. L., J. P. Donval, P. Jean-Baptiste, and A. Dapoigny (1996) Gases and helium isotopes in high temperature solutions sampled before and after ODP Leg 158 drilling at TAG hydrothermal field (26 N, MAR). Geophysical Research Letters 23(23), 3491-3494. 
Charlou, J. L., J. P. Donval, Y. Fouquet, P. Jean-Baptiste, and N. Holm (2002) Geochemistry of high $\mathrm{H}_{2}$ and $\mathrm{CH}_{4}$ vent fluids issuing from ultramafic rocks at the Rainbow hydrothermal field (36²'N, MAR). Chemical Geology 191(4), 345-359.

Cheminée, J. L., P. Stoffers, G. McMurtry, H. Richnow, D. Puteanus, and P. Sedwick (1991) Gas-rich submarine exhalations during the 1989 eruption of Macdonald Seamount. Earth and Planetary Science Letters 107(2), 318-327.

Cline, J. S. and R. J. Bodnar (1991) Can economic porphyry copper mineralization be generated by a typical calc-alkaline melt? Journal of Geophysical Research-Solid Earth and Planets 96(B5), 8113-8126.

Coltice, N., L. Simon, and C. Lecuyer (2004) Carbon isotope cycle and mantle structure. Geophysical Research Letters 31(5).

Corliss, J. B., J. Dymond, L. I. Gordon, J. M. Edmond, R. P. Von Herzen, R. D. Ballard, K. Green, D. Williams, A. Bainbridge, K. Crane et al. (1979) Submarine thermal springs on the Galapagos Rift. Science 203, 1073-1083.

Craddock, P. R. (2008) Geochemical Tracers of Processes Affecting the Formation of Seafloor Hydrothermal Fluids and Deposits in the Manus Back-arc Basin. Ph.D. Thesis. MITWHOI Joint Program in Oceanography, MIT.

Craig, H. (1970) Abyssal Carbon-13 in the South Pacific. Journal of Geophysical Research 75(3), 691-695.

Craig, H. and L. I. Gordon (1965) Deuterium and oxygen 18 variations in the ocean and marine atmosphere. In: Stable Isotopes in Oceanographic Studies and Paleotemperatures, (Ed: E. Tongiogi), Consiglio Nazionale Delle Ricerche, Laboratorio Di Geologia Nucleare, Pisa. pp. 9-130. 
Cruse, A. M. and J. S. Seewald (2006) Geochemistry of low-molecular weight hydrocarbons in hydrothermal fluids from Middle Valley, northern Juan de Fuca Ridge. Geochimica et Cosmochimica Acta 70(8), 2073-2092.

de Ronde, C. E. J. (1995) Fluid chemistry and isotopic characteristics of seafloor hydrothermal systems and associated VMS deposits: potential for magmatic contributions. In: Magmas, fluids, and ore deposits: MAC Short Course Series Vol. 23, (Ed: J. F. H. Thompson), Mineralogical Association of Canada. pp. 479-509.

de Ronde, C. E. J., M. D. Hannington, P. Stoffers, I. C. Wright, R. G. Ditchburn, A. G. Reyes, E. T. Baker, G. J. Massoth, J. E. Lupton, S. L. Walker et al. (2005) Evolution of a submarine magmatic-hydrothermal system: Brothers volcano, southern Kermadec arc, New Zealand. Economic Geology 100(6), 1097-1133.

Douville, E., P. Bienvenu, J. L. Charlou, J. P. Donval, Y. Fouquet, P. Appriou, and T. Gamo (1999) Yttrium and rare earth elements in fluids from various deep-sea hydrothermal systems. Geochimica et Cosmochimica Acta 63(5), 627-643.

Drummond, S. E. (1981) Boiling and mixing of hydrothermal fluids: Chemical effects on mineral precipitation, Ph.D. Dissertation, Penn. State University.

Edmond, J. M., C. Measures, R. E. Mcduff, L. H. Chan, R. Collier, B. Grant, L. I. Gordon, and J. B. Corliss (1979a) Ridge crest hydrothermal activity and the balances of the major and minor elements in the ocean: the Galapagos data. Earth and Planetary Science Letters 46(1), 1-18.

Edmond, J. M., C. Measures, B. Mangum, B. Grant, F. R. Sclater, R. Collier, A. Hudson, L. I. Gordon, and J. B. Corliss (1979b) Formation of Metal-Rich Deposits At Ridge Crests. Earth and Planetary Science Letters 46(1), 19-30. 
Edmond, J. M., A. C. Campbell, M. R. Palmer, G. Klinkhammer, C. German, H. N. Edmonds, H. Elderfield, G. Thompson, and P. Rona (1995) Time series studies of vent fluids from the TAG and MARK sites (1986, 1990) Mid-Atlantic Ridge: a new solution chemistry model and a mechanism for $\mathrm{Cu} / \mathrm{Zn}$ zonation in massive sulphide ore-bodies. In: Hydrothermal Vents and Processes, (Ed: L. Parson and J. R. Dixon), Geological Society Special Publication No. 87. pp. 77-86.

Eickmann, B., W. Bach, M. Rosner, and J. Peckmann (2009) Geochemical constraints on the modes of carbonate precipitation in peridotites from the Logatchev Hydrothermal Vent Field and Gakkel Ridge. Chemical Geology 268(1-2), 97-106.

Embley, R. W., W. W. Chadwick, E. T. Baker, D. A. Butterfield, J. A. Resing, C. E. J. de Ronde, V. Tunnicliffe, J. E. Lupton, S. K. Juniper, K. H. Rubin et al. (2006) Long-term eruptive activity at a submarine arc volcano. Nature 441(7092), 494-497.

Fouquet, Y., U. Vonstackelberg, J. L. Charlou, J. P. Donval, J. Erzinger, J. P. Foucher, P. Herzig, R. Muhe, S. Soakai, M. Wiedicke et al. (1991a) Hydrothermal activity and metallogenesis in the Lau Back-Arc Basin. Nature 349(6312), 778-781.

Fouquet, Y., U. Vonstackelberg, J. L. Charlou, J. P. Donval, J. P. Foucher, J. Erzinger, P. Herzig, R. Muhe, M. Wiedicke, S. Soakai et al. (1991b) Hydrothermal activity in the Lau BackArc Basin - Sulfides and water chemistry. Geology 19(4), 303-306.

Fouquet, Y., U. Vonstackelberg, J. L. Charlou, J. Erzinger, P. M. Herzig, R. Muhe, and M. Wiedicke (1993) Metallogenesis in back-arc environments - The Lau Basin example. Economic Geology 88(8), 2154-2181.

Fournier, R. O. (1983) A method of calculating quartz solubilities in aqueous sodium-chloride solutions. Geochimica et Cosmochimica Acta 47(3), 579-586. 
Fourre, E., P. Jean-Baptiste, J. L. Charlou, J. P. Donval, and J. I. Ishibashi (2006) Helium isotopic composition of hydrothermal fluids from the Manus back-arc Basin, Papua New Guinea. Geochemical Journal 40(3), 245-252.

Foustoukos, D. I. and W. E. Seyfried (2007a) Quartz solubility in the two-phase and critical region of the $\mathrm{NaCl}-\mathrm{KCl}-\mathrm{H}_{2} \mathrm{O}$ system: Implications for submarine hydrothermal vent systems at 9 degrees 50 ' N East Pacific Rise. Geochimica et Cosmochimica Acta 71(1), 186-201.

Foustoukos, D. I. and W. E. Seyfried (2007b) Fluid phase separation processes in submarine hydrothermal systems. In: Fluid-Fluid Interactions, (Ed: A. Liebsher and C. A. Heinrich), Reviews In Mineralogy \& Geochemistry, 65, Mineralogical Society of America. pp. 213239.

Foustoukos, D. I. and W. E. Seyfried (2007c) Trace element partitioning between vapor, brine and halite under extreme phase separation conditions. Geochimica et Cosmochimica Acta 71(8), 2056-2071.

Franklin, J., J. W. Lyndon, and D. F. Sangster (1981) Volcanic-associated massive sulfide deposits. Economic Geology 75, 485-627.

Gallant, R. M. and K. L. Von Damm (2006) Geochemical controls on hydrothermal fluids from the Kairei and Edmond Vent Fields, $23^{\circ}-25^{\circ} \mathrm{S}$, Central Indian Ridge. Geochemistry Geophysics Geosystems 7(6), Q06018, doi:10.1029/2005GC001067.

Galluccio, J., J. Maclean, S. Mcfadyen, J. Moore, P. Saccocia, and J. Seewald (2009) The Mobility of Fluoride in Back-Arc Hydrothermal Systems. Eos Trans. AGU, 90(52), Fall Meet. Suppl. OS13A-1182 (abstr.). 
Gamo, T., H. Sakai, J. Ishibashi, E. Nakayama, K. Isshiki, H. Matsuura, K. Shitashima, K. Takeuchi, and S. Ohta (1993) Hydrothermal plumes in the Eastern Manus Basin, Bismarck Sea $-\mathrm{CH}_{4}, \mathrm{Mn}, \mathrm{Al}$ and $\mathrm{pH}$ anomalies. Deep-Sea Research Part IOceanographic Research Papers 40(11-12), 2335-2349.

Gamo, T., K. Okamura, T. Kodama, J. L. Charlou, T. Urabe, J. M. Auzende, J. Ishibashi, and A. T. S. S. Party (1996a) Chemical characteristics of hydrothermal fluids from the Manus back-arc basin, Papua New Guinea, I. Major Chemical Components. EOS Trans. AGU 77(W116), WPGM Suppl. T32A-5 (abstr.).

Gamo, T., H. Chiba, H. Masuda, H. N. Edmonds, K. Fujioka, Y. Kodama, H. Nanba, and Y. Sano (1996b) Chemical characteristics of hydrothermal fluids from the TAG mound of the Mid-Atlantic Ridge in August 1994: Implications for spatial and temporal variability of hydrothermal activity. Geophysical Research Letters 23(23), 3483-3486.

Gamo, T., K. Okamura, J. L. Charlou, T. Urabe, J. M. Auzende, J. Ishibashi, K. Shitashima, and H. Chiba (1997) Acidic and sulfate-rich hydrothermal fluids from the Manus back-arc basin, Papua New Guinea. Geology 25(2), 139-142.

Gamo, T., J. Ishibashi, U. Tsunogai, K. Okamura, and H. Chiba (2006) Unique geochemistry of submarine hydrothermal fluids from arc-back-arc settings of the Western Pacific. In: Back-Arc Spreading Systems: Geological, Biological, Chemical, and Physical Interactions, (Ed: D. M. Christie, C. R. Fisher, S.-M. Lee, and S. Givens), AGU Mongraph, 166, American Geophysical Union. pp. 147-161.

Gena, K., T. Mizuta, D. Ishiyama, and T. Urabe (2001) Acid-sulphate type alteration and mineralization in the Desmos caldera, Manus back-arc basin, Papua New Guinea. Resource Geology 51(1), 31-44. 
German, C. and K. L. Von Damm (2003) Hydrothermal Processes. In: The Treatise on Geochemistry, (Ed: K. K. Turekian and H. D. Holland), 6.07, Elsevier. pp. 181-222.

Giggenbach, W. F. (1992) Isotopic shifts in waters from geothermal and volcanic systems along convergent plate boundaries and their origin. Earth and Planetary Science Letters 113(4), 495-510.

Goff, F. and G. M. McMurtry (2000) Tritium and stable isotopes of magmatic waters. Journal of Volcanology and Geothermal Research 97(1-4), 347-396.

Goldfarb, M. S., D.R. Converse, H.D. Holland and J.M. Edmond (1983) The genesis of hot spring deposits on the East Pacific Rise, $21^{\circ}$ N. Economic Geology Monograph 5, 184-197.

Hajash, A. and G. W. Chandler (1982) An experimental investigation of high-temperature interactions between seawater and rhyolite, andesite, basalt and peridotite. Contributions to Mineralogy and Petrology 78(3), 240-254.

Hannington, M., P. Herzig, P. Stoffers, J. Scholten, R. Botz, D. Garbe-Schonberg, I. R. Jonasson, and W. Roest (2001) First observations of high-temperature submarine hydrothermal vents and massive anhydrite deposits off the north coast of Iceland. Marine Geology 177(3-4), 199-220.

Haymon, R. M. and M. Kastner (1981) Hot-spring deposits on the East Pacific Rise at $21^{\circ} \mathrm{N}$ preliminary description of mineralogy and genesis. Earth and Planetary Science Letters 53(3), 363-381.

Hedenquist, J. W. and J. B. Lowenstern (1994) The role of magmas in the formation of hydrothermal ore deposits. Nature 370(6490), 519-527.

Herzig, P. M. and M. D. Hannington (1995) Polymetallic massive sulfides at the modern seafloor - a review. Ore Geology Reviews 10(2), 95-115. 
Holland, H. D. (1965) Some applications of thermochemical data to problems in ore deposits II. Mineral assemblages and the composition of ore-forming fluids. Economic Geology 60(6), 1101-1166.

Horita, J., D. R. Cole, and D. J. Wesolowski (1995) The activity-composition relationship of oxygen and hydrogen isotopes in aqueous salt solutions: III. Vapor-liquid water equilibration of $\mathrm{NaCl}$ solutions to $350^{\circ} \mathrm{C}$. Geochimica et Cosmochimica Acta 59(6), $1139-1151$

Hrischeva, E., S. D. Scott, and R. Weston (2007) Metalliferous sediments associated with presently forming volcanogenic massive sulfides: The SuSu knolls hydrothermal field, eastern manus basin, Papua New Guinea. Economic Geology 102(1), 55-73.

Humphris, S. E. and M. K. Tivey (2000) A synthesis of geological and geochemical investigations of the TAG hydrothermal field: Insights into fluid flow and mixing processes in a hydrothermal system. In: Ophiolites and Oceanic Crust: New Insights from Field Studies and the Ocean Drilling Program, (Ed: Y. Dilek, Moores, E.M., Elthon, D. and Nicholas, A.), Special Paper 349, Geological Society of America. pp. 213-235.

Humphris, S. E., P. M. Herzig, D. J. Miller, J. C. Alt, K. Becker, D. Brown, G. Brugmann, H. Chiba, Y. Fouquet, J. B. Gemmell et al. (1995) The internal structure of an active seafloor massive sulfide deposit. Nature 377(6551), 713-716.

Ishibashi, J. and T. Urabe (1995) Hydrothermal activity related to arc-backarc magmatism in the Western Pacific. In: Backarc Basins: Tectonics and Magmatism, (Ed: B. Taylor), Plenum Press. pp. 451-495.

Ishibashi, J. I., H. Wakita, Y. Nojiri, D. Grimaud, P. Jeanbaptiste, T. Gamo, J. M. Auzende, and T. Urabe (1994) Helium and carbon geochemistry of hydrothermal fluids from the North 
Fiji Basin spreading ridge (Southwest Pacific). Earth and Planetary Science Letters 128(3-4), 183-197.

Iwasaki, I. and O. Takejiro (1960) Genesis of sulfate in acid hot spring. Bulletin of the Chemical Society of Japan 33(7), 1018-1019.

Javoy, M., F. Pineau, and J. T. Iiyama (1978) Experimental determination of the isotopic fractionation between gaseous $\mathrm{CO}_{2}$ and carbon dissolved in the tholeiitic magma: a preliminary study. Contributions to Mineralogy and Petrology 67, 35-39.

Kamenetsky, V. S., R. A. Binns, J. B. Gemmell, A. J. Crawford, T. P. Mernagh, R. Maas, and D. Steele (2001) Parental basaltic melts and fluids in eastern Manus backarc Basin: implications for hydrothermal mineralisation. Earth and Planetary Science Letters 184(34), 685-702.

Kamenetsky, V. S., P. Davidson, T. P. Mernagh, A. J. Crawford, J. B. Gemmell, M. V. Portnyagin, and R. Shinjo (2002) Fluid bubbles in melt inclusions and pillow-rim glasses: high-temperature precursors to hydrothermal fluids? Chemical Geology 183(1-4), 349364.

Karl, D. M., G. M. McMurtry, A. Malahoff, and M. O. Garcia (1988) Loihi-Seamount, Hawaii: a mid-plate volcano with a distinctive hydrothermal system. Nature 335(6190), 532-535.

Kelley, D. S. and G. Früh-Green (2000) Volatiles in mid-ocean ridge environments. In: Ophiolites and Ocean Crust: Insights from Field Studies and the Ocean Drilling Program., (Ed: Y. Dilek, E. M. Moores, D. Elthon, and A. Nicholas), Geological Society of America Special Paper 349. pp. 237-260.

Kelley, D. S., M. D. Lilley, and G. L. Früh-Green (2004) Volatiles in submarine environments: food for life. In: The Subseafloor Biosphere at Mid-Ocean Ridges, (Ed: W. S. D. Wilcock, 
E. F. DeLong, D. S. Kelley, J. A. Baross, and S. C. Cary), AGU Monograph, 144, American Geophysical Union. pp. 167-189.

Kendall, C. and T. B. Coplen (1985) Multisample conversion of water to hydrogen by zinc for stable isotope determination. Analytical Chemistry 57(7), 1437-1440.

Kusakabe, M., Y. Komoda, B. Takano, and T. Abiko (2000) Sulfur isotopic effects in the disproportionation reaction of sulfur dioxide in hydrothermal fluids: implications for the $\delta^{34} \mathrm{~S}$ variations of dissolved bisulfate and elemental sulfur from active crater lakes. Journal of Volcanology and Geothermal Research 97(1-4), 287-307.

Lackschewitz, K. S., C. W. Devey, P. Stoffers, R. Botz, A. Eisenhauer, M. Kummetz, M. Schmidt, and A. Singer (2004) Mineralogical, geochemical and isotopic characteristics of hydrothermal alteration processes in the active, submarine, felsic-hosted PACMANUS field, Manus Basin, Papua New Guinea. Geochimica et Cosmochimica Acta 68(21), $4405-4427$.

Lee, S. M. (2003) Multidisciplinary investigation of the Western Pacific I (2000-2001). Ocean Polar Res. 24(3), 131-135.

Lee, S. M. and E. Ruellan (2006) Tectonic and magmatic evolution of the Bismarck Sea, Papua New Guinea: Review and New Synthesis. In: Back-Arc Spreading Systems: Geological, Biological, Chemical, and Physical Interactions, (Ed: D. M. Christie, C. R. Fisher, S.-M. Lee, and S. Givens), AGU Monograph, 166, American Geophysical Union. pp. 263-286.

Lilley, M. D., D. A. Butterfield, J. E. Lupton, and E. J. Olson (2003) Magmatic events can produce rapid changes in hydrothermal vent chemistry. Nature 422(6934), 878-881.

Lisitsyn, A. P., K. Crook, Y. A. Bogdanov, L. P. Zonenshain, K. G. Murav'yev, W. Tufar, Y. G. Gurvich, V. V. Gordeyev, and G. V. Ivanov (1993) A hydrothermal field in the rift zone of the Manus Basin, Bismarck Sea. International Geology Review 35(2), 105-126. 
Lowenstern, J. B. (2000) A review of the contrasting behavior of two magmatic volatiles: chlorine and carbon dioxide. Journal of Geochemical Exploration 69, 287-290.

Lupton, J., D. Butterfield, M. Lilley, L. Evans, K. I. Nakamura, W. Chadwick, J. Resing, R. Embley, E. Olson, G. Proskurowski et al. (2006) Submarine venting of liquid carbon dioxide on a Mariana Arc volcano. Geochemistry Geophysics Geosystems 7(8), 1-20.

Lupton, J., M. Lilley, D. Butterfield, L. Evans, R. Embley, G. Massoth, B. Christenson, K. Nakamura, and M. Schmidt (2008) Venting of a separate $\mathrm{CO}_{2}$-rich gas phase from submarine arc volcanoes: Examples from the Mariana and Tonga-Kermadec arcs. Journal of Geophysical Research-Solid Earth 113(B8).

Maris, C. R. P., M. L. Bender, P. N. Froelich, R. Barnes, and N. A. Luedtke (1984) Chemical evidence for advection of hydrothermal solutions in the sediments of the galapagos mounds hydrothermal field. Geochimica et Cosmochimica Acta 48(11), 2331-2346.

Martinez, F. and B. Taylor (1996) Backarc spreading, rifting, and microplate rotation, between transform faults in the Manus basin. Marine Geophysical Researches 18(2-4), 203-224.

Marty, B., Y. Sano, and C. France-Lanord (2001) Water-saturated oceanic lavas from the Manus Basin: volatile behaviour during assimilation-fractional crystallisation-degassing (AFCD). Journal of Volcanology and Geothermal Research 108(1-4), 1-10.

Massoth, G. J., D. A. Butterfield, J. E. Lupton, R. E. Mcduff, M. D. Lilley, and I. R. Jonasson (1989) Submarine venting of phase-separated hydrothermal fluids at Axial Volcano, Juan De Fuca Ridge. Nature 340(6236), 702-705.

Mattey, D. P. (1991) Carbon-dioxide solubility and carbon isotope fractionation in basaltic melt. Geochimica et Cosmochimica Acta 55(11), 3467-3473.

McCollom, T. M. and J. S. Seewald (2007) Abiotic synthesis of organic compounds in deep-sea hydrothermal environments. Chemical Reviews 107, 382-401. 
McDermott, J. M and Von Damm, K. L. (2008) On the re-dissolution of subsurface hydrothermal deposits at $9^{\circ} 50^{\prime} \mathrm{N}$ East Pacific Rise: Implications from geochemical studies of high- and low-temperature fluids. EOS Trans. AGU 89(53), Fall Meet. Suppl. B51D-0402 (abstr.).

McMurtry, G. M., P. N. Sedwick, P. Fryer, D. L. Vonderhaar, and H. W. Yeh (1993) Unusual geochemistry of hydrothermal vents on submarine arc volcanos - Kasuga Seamounts, Northern Mariana Arc. Earth and Planetary Science Letters 114(4), 517-528.

Michael, P. J. and W. C. Cornell (1998) Influence of spreading rate and magma supply on crystallization and assimilation beneath mid-ocean ridges: Evidence from chlorine and major element chemistry of mid-ocean ridge basalts. Journal of Geophysical ResearchSolid Earth 103(B8), 18325-18356.

Michael, P. J. and J. G. Schilling (1989) Chlorine in mid-ocean ridge magmas: Evidence for assimilation of seawater-influenced components. Geochimica et Cosmochimica Acta 53(12), 3131-3143.

Michard, G., F. Albarède, A. Michard, J. F. Minster, J. L. Charlou, and N. Tan (1984) Chemistry of solutions from the $13^{\circ} \mathrm{N}$ East Pacific Rise hydrothermal site. Earth and Planetary Science Letters 67(3), 297-307.

Mills, R. A. and M. Tivey (1999) Seawater entrainment and fluid evolution within the TAG hydrothermal mound: evidence from analyses of anhydrite. In: Mid-Ocean Ridges: Dynamics of processes associated with creation of new ocean crust, (Ed: J. R. Cann, H. Elderfield, and A. Laughton), Cambridge University Press. pp. 225-248.

Monecke, T., G. Giorgetti, O. Scholtysek, R. Kleeberg, J. Gotze, M. D. Hannington, and S. Petersen (2007) Textural and mineralogical changes associated with the incipient hydrothermal alteration of glassy dacite at the submarine PACMANUS hydrothermal 
system, eastern Manus Basin. Journal of Volcanology and Geothermal Research 160(12), 23-41.

Moss, R. and S. D. Scott (2001) Geochemistry and mineralogy of gold-rich hydrothermal precipitates from the eastern Manus Basin, Papua New Guinea. Canadian Mineralogist 39, 957-978.

Mottl, M. J. and H. D. Holland (1978) Chemical exchange during hydrothermal alteration of basalt by seawater-I. Experimental results for major and minor components of seawater. Geochimica et Cosmochimica Acta 42(8), 1103-1115.

Mottl, M. J., H. D. Holland, and R. F. Corr (1979) Chemical exchange during hydrothermal alteration of basalt by seawater-II. Experimental results for Fe, Mn, and sulfur species. Geochimica et Cosmochimica Acta 43(6), 869-884.

Nakagawa, T., K. Takai, Y. Suzuki, H. Hirayama, U. Konno, U. Tsunogai, and K. Horikoshi (2006) Geomicrobiological exploration and characterization of a novel deep-sea hydrothermal system at the TOTO caldera in the Mariana Volcanic Arc. Environmental Microbiology 8(1), 37-49.

Nilsson, K. and C. L. Peach (1993) Sulfur speciation, oxidation state, and sulfur concentration in backarc magmas. Geochimica et Cosmochimica Acta 57(15), 3807-3813.

Ogawa, Y., N. Shikazono, D. Ishiyama, H. Sato, and T. Mizuta (2005) An experimental study on felsic rock-artificial seawater interaction: implications for hydrothermal alteration and sulfate formation in the Kuroko mining area of Japan. Mineralium Deposita 39(8), 813821.

Ohmoto, H. (1986) Stable isotope geochemistry of ore deposits. In: Stable Isotopes in High Temperature Geological Processes, (Ed: J. W. Valley, H. P. Taylor, and J. R. O'Neil), Reviews in Mineralogy, 16, Mineralogical Society of America. pp. 491-559. 
Ohmoto, H. and M. B. Goldhaber (1997) Sulfur and carbon isotopes. In: Geochemistry of Hydrothermal Ore Deposits, (Ed: H. L. Barnes), Wiley. pp. 517-612.

Ohmoto, H. and A. C. Lasaga (1982) Kinetics of reactions between aqueous sulfates and sulfides in hydrothermal systems. Geochimica et Cosmochimica Acta 46(10), 1727-1745.

Ohmoto, H. and R. Rye (1979) Isotopes of Sulfur and Carbon. In: Geochemistry of Hydrothermal Ore Deposits, (Ed: H. L. Barnes), Wiley. pp. 509-567.

Park, S. H., S.-M. Lee, G. D. Kamenov, S.-T. Kwon, and K.-Y. Lee (in press) Tracing the origin of subduction components beneath the South East rift in the Manus Basin, Papua New Guinea. Chemical Geology (doi:10.1016/j.chemgeo.2009.10.008).

Paulick, H. and W. Bach (2006) Phyllosilicate alteration mineral assemblages in the active subsea-floor Pacmanus hydrothermal system, Papua New Guinea, ODP Leg 193. Economic Geology 101(3), 633-650.

Paulick, H., D. A. Vanko, and C. J. Yeats (2004) Drill core-based facies reconstruction of a deepmarine felsic volcano hosting an active hydrothermal system (Pual Ridge, Papau New Guinea, ODP Leg 193). Journal of Volcanology and Geothermal Research 130(1-2), 3150.

Pearce, J. A. and R. J. Stern (2006) Origin of back-arc basin magmas: trace element and isotope perspectives. In: Back-Arc Spreading Systems: Geological, Biological, Chemical, and Physical Interactions, (Ed: D. M. Christie, C. R. Fisher, S.-M. Lee, and S. Givens), AGU Monograph, 166, American Geophysical Union. pp. 63-86.

Pineau, F., M. Javoy, and Y. Bottinga $(1976){ }^{13} \mathrm{C} /{ }^{12} \mathrm{C}$ ratios of rocks and inclusions in popping rocks of the mid-atlantic ridge and their bearing on the problem of isotopic composition of deep-seated carbon. Earth and Planetary Science Letters 29, 413-421. 
Pineau, F., S. Shilobreeva, A. Kadik, and M. Javoy (1998) Water solubility and D/H fractionation in the system basaltic andesite- $\mathrm{H}_{2} \mathrm{O}$ at $1250^{\circ} \mathrm{C}$ and between 0.5 and 3 kbars. Chemical Geology 147(1-2), 173-184.

Proskurowski, G., J. S. Seewald, E. Reeves, M. McCollom Thomas, J. Lupton, S. P. Sylva, and M. K. Tivey (2007) Volatile chemistry at Lau Basin hydrothermal sites: Basin-wide trends of slab carbonate influence and suggestions of abiotic methane oxidation at the Mariner vent

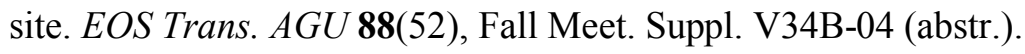

Redfield, A. C. and I. Friedman (1965) Factors affecting the distribution of deuterium in the ocean. In: Symposium on Marine Geochemistry, (Ed: D. R. Schink and J. T. Corless), Occasional Publication no. 3, Narragansett Marine Laboratory, University of Rhode Island. pp. 149-168.

Rees, C. E., W. J. Jenkins, and J. Monster (1978) Sulfur isotopic composition of ocean water sulfate. Geochimica et Cosmochimica Acta 42(4), 377-381.

Resing, J. A., G. Lebon, E. T. Baker, J. E. Lupton, R. W. Embley, G. J. Massoth, W. W. Chadwick, and C. E. J. de Ronde (2007) Venting of acid-sulfate fluids in a highsulfidation setting at NW Rota-1 submarine volcano on the Mariana Arc. Economic Geology 102(6), 1047-1061.

Roberts, S., W. Bach, R. A. Binns, D. A. Vanko, C. J. Yeats, D. A. H. Teagle, K. Blacklock, J. S. Blusztajn, A. J. Boyce, M. J. Cooper et al. (2003) Contrasting evolution of hydrothermal fluids in the PACMANUS system, Manus Basin: The Sr and S isotope evidence. Geology 31(9), 805-808.

Rosenbauer, R. J. and J. L. Bischoff (1983) Uptake and transport of heavy metals by heated seawater: a summary of experimental results. In: Hydrothermal Processes at Seafloor 
Spreading Centers, NATO Conference Series, (Ed: P. Rona, K. Bostrom, L. Laubier, and K. Smith), IV:12, Plenum Press.

Ryan, J. G. and C. H. Langmuir (1993) The systematics of boron abundances in young volcanic rocks. Geochimica et Cosmochimica Acta 57(7), 1489-1498.

Sakai, H., T. Gamo, E. S. Kim, K. Shitashima, F. Yanagisawa, M. Tsutsumi, J. Ishibashi, Y. Sano, H. Wakita, T. Tanaka et al. (1990a) Unique chemistry of the hydrothermal solution in the Mid-Okinawa Trough Backarc Basin. Geophysical Research Letters 17(12), 2133-2136.

Sakai, H., T. Gamo, E. S. Kim, M. Tsutsumi, T. Tanaka, J. Ishibashi, H. Wakita, M. Yamano, and T. Oomori (1990b) Venting of carbon dioxide-rich fluid and hydrate formation in MidOkinawa Trough Backarc Basin. Science 248(4959), 1093-1096.

Sarmiento, J. L. and N. Gruber (2006) Ocean Biogeochemical Dynamics. Princeton University Press.

Scaillet, B. and M. Pichavant (2003) Experimental constraints on volatile abundances in arc magmas and their implications for degassing processes. Geological Society, London, Special Publications 213, 23-52.

Schoofs, S. and U. Hansen (2000) Depletion of a brine layer at the base of ridge-crest hydrothermal systems. Earth and Planetary Science Letters 180(3-4), 341-353.

Sedwick, P. N., G. M. McMurtry, and J. D. Macdougall (1992) Chemistry of hydrothermal solutions from Pele Vents, Loihi Seamount, Hawaii. Geochimica et Cosmochimica Acta 56(10), 3643-3667.

Seewald, J. S. and W. E. Seyfried (1990) The effect of temperature on metal mobility in subseafloor hydrothermal systems: constraints from basalt alteration experiments. Earth and Planetary Science Letters 101(2-4), 388-403. 
Seewald, J., A. Cruse, and P. Saccocia (2003) Aqueous volatiles in hydrothermal fluids from the Main Endeavour Field, northern Juan de Fuca Ridge: temporal variability following earthquake activity. Earth and Planetary Science Letters 216(4), 575-590.

Seewald, J. S., K. W. Doherty, T. R. Hammar, and S. P. Liberatore (2002) A new gas-tight isobaric sampler for hydrothermal fluids. Deep-Sea Research Part I-Oceanographic Research Papers 49(1), 189-196.

Seewald, J., T. Mccollum, G. Proskurowski, E. Reeves, M. Mottl, J. Sharkey, G. Wheat, and M. K. Tivey (2005) Aqueous volatiles in Lau Basin hydrothermal fluids. EOS Trans. $A G U$ 86(52), Fall Meet. Suppl. T31A-0478 (abstr.).

Seyfried, W. E. (1987) Experimental and theoretical constraints on hydrothermal alteration processes at mid-ocean ridges. Annual Review of Earth and Planetary Sciences 15, 317 335.

Seyfried, W. E. and J. L. Bischoff (1981) Experimental seawater-basalt interaction at $300^{\circ} \mathrm{C}, 500$ bars, chemical exchange, secondary mineral formation and implications for the transport of heavy-metals. Geochimica et Cosmochimica Acta 45(2), 135-147.

Seyfried, W. E. and K. Ding (1995a) The hydrothermal chemistry of fluoride in seawater. Geochimica et Cosmochimica Acta 59(6), 1063-1071.

Seyfried, W. E. and K. Ding (1995b) Phase equilibria in subseafloor hydrothermal systems: a review of the role of redox, temperature, $\mathrm{pH}$ and dissolved $\mathrm{Cl}$ on the chemistry of hot spring fluids at mid-ocean ridges. In: Seafloor Hydrothermal Systems: Physical, Chemical, Biological, and Geological Interactions, (Ed: S. E. Humphris, R. A. Zierenberg, L. S. Mullineaux, and R. E. Thomson), AGU Monograph, 91, American Geophysical Union. pp. 248-272. 
Seyfried, W. E. and D. R. Janecky (1985) Heavy metal and sulfur transport during subcritical and supercritical hydrothermal alteration of basalt: Influence of fluid pressure and basalt composition and crystallinity. Geochimica et Cosmochimica Acta 49(12), 2545-2560.

Seyfried, W. E. and M. J. Mottl (1982) Hydrothermal alteration of basalt by seawater under seawater-dominated conditions. Geochimica et Cosmochimica Acta 46(6), 985-1002.

Seyfried, W. E., D. R. Janecky, and M. J. Mottl (1984) Alteration of the oceanic crust: Implications for geochemical cycles of lithium and boron. Geochimica et Cosmochimica Acta 48(3), 557-569.

Shanks, W. C. (2001) Stable isotopes in seafloor hydrothermal systems: Vent fluids, hydrothermal deposits, hydrothermal alteration, and microbial processes. In: Stable Isotope Geochemistry, (Ed: J. W. Valley and D. R. Cole), Reviews in Mineralogy \& Geochemistry, 43, Mineralogical Society of America. pp. 469-525.

Shanks, W. C. and W. E. Seyfried (1987) Stable isotope studies of vent fluids and chimney minerals, Southern Juan De Fuca Ridge: Sodium metasomatism and seawater sulfate reduction. Journal of Geophysical Research-Solid Earth and Planets 92(B11), 1138711399.

Shanks, W. C., J. K. Böhlke, and R. R. Seal (1995) Stable isotopes in mid-ocean ridge hydrothermal systems: interactions between fluids, minerals, and organisms. In: Seafloor Hydrothermal Systems: Physical, Chemical, Biological, and Geological Interactions, (Ed: S. E. Humphris, R. A. Zierenberg, L. S. Mullineaux, and R. E. Thomson), AGU Monograph, 91, American Geophysical Union. pp. 194-221.

Shaw, A. M., D. R. Hilton, C. G. Macpherson, and J. M. Sinton (2004) The $\mathrm{CO}_{2}-\mathrm{He}-\mathrm{Ar}^{-} \mathrm{H}_{2} \mathrm{O}$ systematics of the Manus back-arc basin: Resolving source composition from degassing and contamination effects. Geochimica et Cosmochimica Acta 68(8), 1837-1856. 
Shaw, A. M., E. H. Hauri, T. P. Fischer, D. R. Hilton, and K. A. Kelley (2008) Hydrogen isotopes in Mariana arc melt inclusions: Implications for subduction dehydration and the deepEarth water cycle. Earth and Planetary Science Letters 275(1-2), 138-145.

Shikazono, N. and H. D. Holland (1983) The partitioning of Sr between anhydrite and aqueous solutions from 150 to $250^{\circ} \mathrm{C}$, The Kuroko and Related Volcanogenic Massive Sulfide Deposits. Economic Geology Monograph 5, 320-328.

Shinohara, H. (1994) Exsolution of immiscible vapor and liquid phases from a crystallizing silicate melt: Implications for chlorine and metal transport. Geochimica et Cosmochimica Acta 58(23), 5215-5221.

Shiraki, R., H. Sakai, M. Endoh, and N. Kishima (1987) Experimental studies on rhyoliteseawater and andesite-seawater interactions at $300^{\circ} \mathrm{C}$ and 1000 bars. Geochemical Journal 21(4), 139-148.

Shmulovich, K. I., D. Landwehr, K. Simon, and W. Heinrich (1999) Stable isotope fractionation between liquid and vapour in water-salt systems up to $600^{\circ} \mathrm{C}$. Chemical Geology 157(34), 343-354.

Simmons, S. F. and K. L. Brown (2006) Gold in magmatic hydrothermal solutions and the rapid formation of a giant ore deposit. Science 314(5797), 288-291.

Sinton, J. M., L. L. Ford, B. Chappell, and M. T. Mcculloch (2003) Magma genesis and mantle heterogeneity in the Manus back-arc basin, Papua New Guinea. Journal of Petrology 44(1), 159-195.

Snyder, G. T., U. Fehn, and R. Goff (2002) Iodine isotope ratios and halide concentrations in fluids of the Satsuma-Iwojima volcano, Japan. Earth Planets and Space 54(3), 265-273. 
Spencer, D. W., D. E. Robertson, K. K. Turekian, and T. R. Folsom (1970) Trace element calibrations and profiles at the GEOSECS test station in the Northeast Pacific Ocean. Journal of Geophysical Research 75(36), 7688-7696.

Spivack, A. J. and J. M. Edmond (1987) Boron isotope exchange between seawater and the oceanic crust. Geochimica et Cosmochimica Acta 51(5), 1033-1043.

Stoffers, P., T. J. Worthington, U. Schwarz-Schampera, M. D. Hannington, G. J. Massoth, R. Hekinian, M. Schmidt, L. J. Lundsten, L. J. Evans, R. Vaiomo'unga et al. (2006) Submarine volcanoes and high-temperature hydrothermal venting on the Tonga arc, southwest Pacific. Geology 34(6), 453-456.

Sun, W. D., R. J. Arculus, V. S. Kamenetsky, and R. A. Binns (2004) Release of gold-bearing fluids in convergent margin magmas prompted by magnetite crystallization. Nature 431(7011), 975-978.

Sun, W. D., R. A. Binns, A. C. Fan, V. S. Kamenetsky, R. Wysoczanski, G. J. Wei, Y. H. Hu, and R. J. Arculus (2007) Chlorine in submarine volcanic glasses from the eastern Manus basin. Geochimica et Cosmochimica Acta 71(6), 1542-1552.

Takai, K., T. Nunoura, J. I. Ishibashi, J. Lupton, R. Suzuki, H. Hamasaki, Y. Ueno, S. Kawagucci, T. Gamo, Y. Suzuki et al. (2008) Variability in the microbial communities and hydrothermal fluid chemistry at the newly discovered Mariner hydrothermal field, southern Lau Basin. Journal of Geophysical Research-Biogeosciences 113(G02031), doi:10.1029/2007JG000636.

Taylor, B. (1979a) Bismarck Sea: evolution of a back-arc basin. Geology 7(171-174).

Taylor, B. E. (1986) Magmatic volatiles: isotopic variation of C, H, and S. In: Stable isotopes in high temperature geological processes, (Ed: J. W. Valley, H. P. Taylor, and J. R. O'Neil), Reviews in Mineralogy, 16, Mineralogical Society of America. pp. 185-225. 
Taylor, H. P. (1979b) Oxygen and hydrogen isotope relationships in hydrothermal mineral deposits. In: Geochemistry of Hydrothermal Ore Deposits, (Ed: H. L. Barnes), Wiley. pp. 236-277.

Taylor, B., K. Crook, and J. Sinton (1994) Extensional transform zones and oblique spreading centers. Journal of Geophysical Research-Solid Earth 99(B10), 19707-19718.

Taylor, H. P. (1997) Oxygen and hydrogen isotope relationships in hydrothermal mineral deposits. In: Geochemistry of Hydrothermal Ore Deposits, (Ed: H. L. Barnes), Wiley. pp. 229-302.

Tivey, M., W. Bach, J. Seewald, M. K. Tivey, D. A. Vanko and the Shipboard Science Party (2006) Cruise Report for R/V Melville cruise MGLN06MV - Hydrothermal systems in the Eastern Manus Basin: Fluid Chemistry and Magnetic Structure as Guides to Subseafloor Processes. Woods Hole Oceanographic Institution (available upon request to authors).

Tivey, M. K., S. E. Humphris, G. Thompson, M. D. Hannington, and P. A. Rona (1995) Deducing patterns of fluid flow and mixing within the TAG active hydrothermal mound using mineralogical and geochemical data. Journal of Geophysical Research-Solid Earth 100(B7), 12527-12555.

Trefry, J. H., D. B. Butterfield, S. Metz, G. J. Massoth, R. P. Trocine, and R. A. Feely (1994) Trace metals in hydrothermal solutions from cleft segment on the southern Juan De Fuca Ridge. Journal of Geophysical Research-Solid Earth 99(B3), 4925-4935.

Tregoning, P. (2002) Plate kinematics in the western Pacific derived from geodetic observations. Journal of Geophysical Research-Solid Earth 107(B1).

Tsunogai, U., J. Ishibashi, H. Wakita, T. Gamo, K. Watanabe, T. Kajimura, S. Kanayama, and H. Sakai (1994) Peculiar features of Suiyo Seamount hydrothermal fluids, Izu-Bonin Arc: differences from subaerial volcanism. Earth and Planetary Science Letters 126(4), 289301. 
Tufar, W. (1990) Modern hydrothermal activity, formation of complex massive sulfide deposits and associated vent communities in the Manus Back-arc Basin (Bismarck Sea, Papua New Guinea). Mitteilung der Osterreichen Geologischen Gesellshaft 82, 183-210.

Von Damm, K. L. (1988) Systematics of and postulated controls on submarine hydrothermal solution chemistry. Journal of Geophysical Research-Solid Earth and Planets 93(B5), $4551-4561$.

Von Damm, K. L. (1990) Seafloor Hydrothermal Activity - Black Smoker Chemistry and Chimneys. Annual Review of Earth and Planetary Sciences 18, 173-204.

Von Damm, K. L. (1995) Controls on the chemistry and temporal variability of seafloor hydrothermal systems. In: Seafloor Hydrothermal Systems: Physical, Chemical, Biological, and Geological Interactions, (Ed: S. E. Humphris, R. A. Zierenberg, L. S. Mullineaux, and R. E. Thomson), AGU Monograph, 91, American Geophysical Union. pp. 222-247.

Von Damm, K. L. and J. L. Bischoff (1987) Chemistry of hydrothermal solutions from the Southern Juan De Fuca Ridge. Journal of Geophysical Research-Solid Earth and Planets 92(B11), 11334-11346.

Von Damm, K. L., J. M. Edmond, B. Grant, and C. I. Measures (1985) Chemistry of submarine hydrothermal solutions at $21^{\circ} \mathrm{N}$, East Pacific Rise. Geochimica et Cosmochimica Acta 49(11), 2197-2220.

Von Damm, K. L., J. L. Bischoff, and R. J. Rosenbauer (1991) Quartz solubility in hydrothermal seawater: an experimental study and equation describing quartz solubility for up to $0.5-\mathrm{M}$ $\mathrm{NaCl}$ solutions. American Journal of Science 291(10), 977-1007. 
Von Damm, K. L., A. M. Bray, L. G. Buttermore, and S. E. Oosting (1998) The geochemical controls on vent fluids from the Lucky Strike vent field, Mid-Atlantic Ridge. Earth and Planetary Science Letters 160(3-4), 521-536.

Von Damm, K. L., C. M. Parker, R. A. Zierenberg, M. D. Lilley, E. J. Olson, D. A. Clague, and J. S. Mcclain (2005) The Escanaba Trough, Gorda Ridge hydrothermal system: Temporal stability and subseafloor complexity. Geochimica et Cosmochimica Acta 69(21), 49714984.

Wallace, P. J. (2005) Volatiles in subduction zone magmas: concentrations and fluxes based on melt inclusion and volcanic gas data. Journal of Volcanology and Geothermal Research 140(1-3), 217-240.

Webster, J. D. (2004) The exsolution of magmatic hydrosaline chloride liquids. Chemical Geology 210(1-4), 33-48.

Welhan, J. A. (1988) Origins of methane in hydrothermal systems. Chemical Geology 71(1-3), 183-198.

Yang, K. H. and S. D. Scott (1996) Possible contribution of a metal-rich magmatic fluid to a seafloor hydrothermal system. Nature 383(6599), 420-423.

Yang, K. H. and S. D. Scott (2002) Magmatic degassing of volatiles and ore metals into a hydrothermal system on the modern sea floor of the eastern Manus back-arc basin, western Pacific. Economic Geology 97(5), 1079-1100.

Yang, K. H. and S. D. Scott (2005) Vigorous exsolution of volatiles in the magma chamber beneath a hydrothermal system on the modern sea floor of the eastern Manus back-arc basin, western Pacific: Evidence from melt inclusions. Economic Geology 100(6), 10851096. 
Yang, K. and S. D. Scott (2006) Magmatic fluids as a source of metals in seafloor hydrothermal systems. In: Back-Arc Spreading Systems: Geological, Biological, Chemical, and Physical Interactions, (Ed: D. M. Christie, C. R. Fisher, S.-M. Lee, and S. Givens), AGU Mongraph, 166, American Geophysical Union. pp. 163-184.

Zengqian, H., K. Zaw, L. Yahne, Z. Qiling, Z. Zhignag, and T. Urabe (2005) Contribution of magmatic fluid to the active hydrothermal system in the JADE Field, Okinawa Trough: Evidence from fluid inclusions, oxygen and helium isotopes. International Geology Review 47, 420-437. 


\section{CHAPTER 6}

\section{Comments and future research directions}

This section briefly outlines any criticisms of the previous four chapters as well as highlighting future directions of research each respective area should progress toward.

CHAPTER 2 demonstrates that $\mathrm{CO}_{2}$ reduction in the absence of mineral catalysis does proceed on timescales relevant to estimated fluid residence times in seafloor hydrothermal systems. Our understanding of the likelihood of $\mathrm{CH}_{4}$ formation via $\mathrm{CH}_{3} \mathrm{OH}$ in hydrothermal systems will be greatly improved if the distribution of the latter is characterized in vent fluids as a function of temperature and redox. A correlation of $\mathrm{CH}_{3} \mathrm{OH}$ abundance with aqueous $\mathrm{H}_{2}$ across the spectrum of redox states between basalt-hosted and ultramafic-hosted hydrothermal systems would provide compelling evidence of formation of $\mathrm{CH}_{3} \mathrm{OH}$ by a reductive process. Measured concentrations could be evaluated in a thermodynamic context and may provide an insight into subsurface conditions if temperatures of equilibration are higher than measured vent temperatures. Furthermore, additional experimental work aimed at constraining the carbon isotopic fractionations associated with $\mathrm{CH}_{4}$ formation via $\mathrm{CH}_{3} \mathrm{OH}$ may aid in understanding in the isotopic composition of $\mathrm{CH}_{4}$ in unsedimented hydrothermal systems.

By characterizing the distribution of $\mathrm{CH}_{3} \mathrm{SH}$ in present day vent fluids, CHAPTER 3 represents a first step in testing the assumptions inherent in the 'metabolism-first' model for the origin of chemoautotrophic life. However, further work is needed to constrain the origin of $\mathrm{CH}_{3} \mathrm{SH}$ observed in vent fluids. In particular, the possibility of $\mathrm{CH}_{3} \mathrm{SH}$ production by pyrolysis of biological materials in unsedimented hydrothermal systems must be thoroughly examined, both through experimental work and further characterization of $\mathrm{CH}_{3} \mathrm{SH}$ in low to moderate 
temperature fluids where this process may occur. The possibility of organic compound production via biomass pyrolysis is still in infancy as a research direction and no major studies have been conducted to examine this process. PROSKUROWSKI et al. (2008) speculated on the significance of this process for $\mathrm{CH}_{4}$ production but key questions still remain. Specifically, what is the lower temperature limit at which thermogenic alteration of vent biomass ceases to occur, and what is the temporal extent of biomass available for alteration? If biomass alteration is simply a transient process related to shifts in the hydrologic regime (e.g. passage of hotter fluids through conduits that previously experienced much cooler temperatures and more active biomass production), then temporal variations should be evident in the organic composition of low temperature/diffuse fluids. Clear demonstration of biomass pyrolysis as a source of organic compounds such as $\mathrm{CH}_{3} \mathrm{SH}$ to fluids will significantly complicate the identification of truly abiotic organic processes in bare rock systems. Isotopic analyses could provide useful information on the origin of $\mathrm{CH}_{3} \mathrm{SH}$, but will likely face analytically challenges given the trace quantities present and the labile nature of $\mathrm{CH}_{3} \mathrm{SH}$ with respect to oxidation in storage. Analysis of the radiocarbon content of $\mathrm{CH}_{3} \mathrm{SH}$ in vent fluids could provide definitive evidence for abiotic vs. thermogenic origins (PROSKUROWSKI et al., 2008) but this is simply not possible at the present time. The advent of compound-specific sulfur isotope analysis may provide some insight into the origin of $\mathrm{CH}_{3} \mathrm{SH}$ if issues of sample storage are addressed.

CHAPTER 4 presents compelling evidence for hydrogen isotope exchange between $n$ alkanes and water under hydrothermal conditions. Unfortunately, the experiments in CHAPTER 4 cannot be used to derive accurate estimates of alkane-water hydrogen isotope fractionation factors or rate constants for exchange at the conditions of the experiments. Both $\mathrm{k}$ and $\mathrm{F}_{\mathrm{eq}}$ in equation (7), CHAPTER 4, are unknown and because of the nature of these experiments it is difficult to derive their magnitudes accurately. The time series isotopic compositions in Experiments 1 and 2 
cannot be viewed as partial exchange scenarios (e.g. SUZUOKI and EPSTEIN, 1976; SACCOCIA et al., 2009) in order to derive $\mathrm{F}_{\mathrm{eq}}$ because the fundamental assumption of this technique (that equivalent fractions of exchange occur per unit time between parallel experiments) is likely to be invalid. This is due to differing hydrocarbon concentrations and concomitant effects on the observed rate of exchange which simply arise from the difficulties in loading the reaction cell contents accurately. Furthermore, differing $\mathrm{H}_{2}$ and alkene abundances between experiments will also likely influence the validity of that assumption. Alternatively, the use of non-linear least squares regression techniques (e.g. a Levenberg-Marquardt Method, BEVINGTON and RoBINSON, 2003 ) to fit equation (7) to the observed trends yields highly erratic values of $F_{\text {eq }}$ and $k_{\text {obs }}$ between the experiments due to excessive degrees of extrapolation and estimated values of $\mathrm{k}_{\text {obs }}$ would therefore have very weak predictive capabilities. Finally, because exchange occurred in the bulk molecule and not at specific carbon positions, it would not be possible to derive carbon-specific fractionation factors for alkane $\mathrm{H}$ and water based on such results.

While these drawbacks do not compromise the contribution of CHAPTER 4, estimates of fractionation factors above the $100^{\circ} \mathrm{C}$ limit of WANG et al. $(2009 \mathrm{a}, \mathrm{b})$ to temperatures encountered by dissolved hydrocarbons in hydrothermal systems $\left(\sim 400^{\circ} \mathrm{C}\right)$ would be useful in confirming the extents of exchange occurring in seafloor hydrothermal systems. The lack of substantial temperature dependency of $\alpha_{\mathrm{o} / \mathrm{w}}$ values below $100^{\circ} \mathrm{C}$ (CHAPTER 4, Figure 4.9; WANG et al., 2009b) could reasonably be extended to slightly higher temperatures, but it would be unwise to assume such insensitivity holds to $\sim 400^{\circ} \mathrm{C}$. Unfortunately, there are likely to be significant challenges in experimentally determining these values at such high temperatures. WANG et al. $(2009 \mathrm{a}, \mathrm{b})$ used a keto-enol tautomerization reaction mechanism to equilibrate water with $\mathrm{H}$ bound to individual carbon positions adjacent to carbonyl groups in a suite of aliphatic, branched and aromatic ketones. However, it is highly unlikely such a mechanism could be used to achieve the 
same result under hydrothermal conditions given the demonstrated potential for aqueous ketone oxidation at elevated temperatures (SEEWALD, 2001). An approach similar to HORIBE and CRAIG (1995), whereby gaseous mixtures of $\mathrm{CH}_{4}$ and $\mathrm{H}_{2}$ were isotopically equilibrated over a Ni-Thoria catalyst, might be possible for low molecular weight alkanes and water, but this is speculative and would not allow for carbon-specific $\mathrm{H}$ equilibration.

CHAPTER 5 illustrates that magmatic fluids and subsurface mixing processes can influence the chemistry of convectively circulating hydrothermal fluids in backarc environments. Figure 6.1 shows a cartoon of the proposed evolution of circulating fluids in a PACMANUS-type hydrothermal system. A key question arising from this study is on what temporal scales magmatic fluid inputs occur. YANG and SCOTT (2005) argue that the exsolution of magmatic volatiles from differentiating silicic magmas could proceed for extended periods of time (on the order of years to decades), thereby having the potential to influence hydrothermal fluid compositions for much of the typical lifetime of sites of hydrothermal activity. This remains to be demonstrated, but is important given the hypothesized role of magmatic fluids in contributing substantial quantities of economic metals to seafloor massive sulfide deposits in backarc hydrothermal systems (YANG and SCOTT, 1996, 2002, 2005, 2006). However, the data presented in CHAPTER 5 only represent a snapshot in time and considerable time series studies must be conducted before such hypotheses can be validated. Future expeditions to the Manus Basin, within the next few years will shed valuable light on the temporal evolution of magmatic inputs and mixing processes. Another potential avenue of research related to CHAPTER 5 involves an examination of the role of water/rock reactions in buffering $\mathrm{pH}$ to very low values. In some of the vent fluids at PACMANUS which lack substantial magmatic $\mathrm{CO}_{2}$ contents (e.g. Roman Ruins and Roger's Ruins), pH values are similar to fluids with substantial magmatic inputs (e.g. Satanic Mills and Snowcap). This strongly suggests some component of water/rock reaction in regulating 
fluid $\mathrm{pH}$. Whether this occurs by incomplete titration of magma-derived acidity following magmatic fluid input or by buffering induced by pre-existing acid-sulfate alteration assemblages could be examined both experimentally with water/rock reaction experiments and theoretically using reaction-path modeling. 


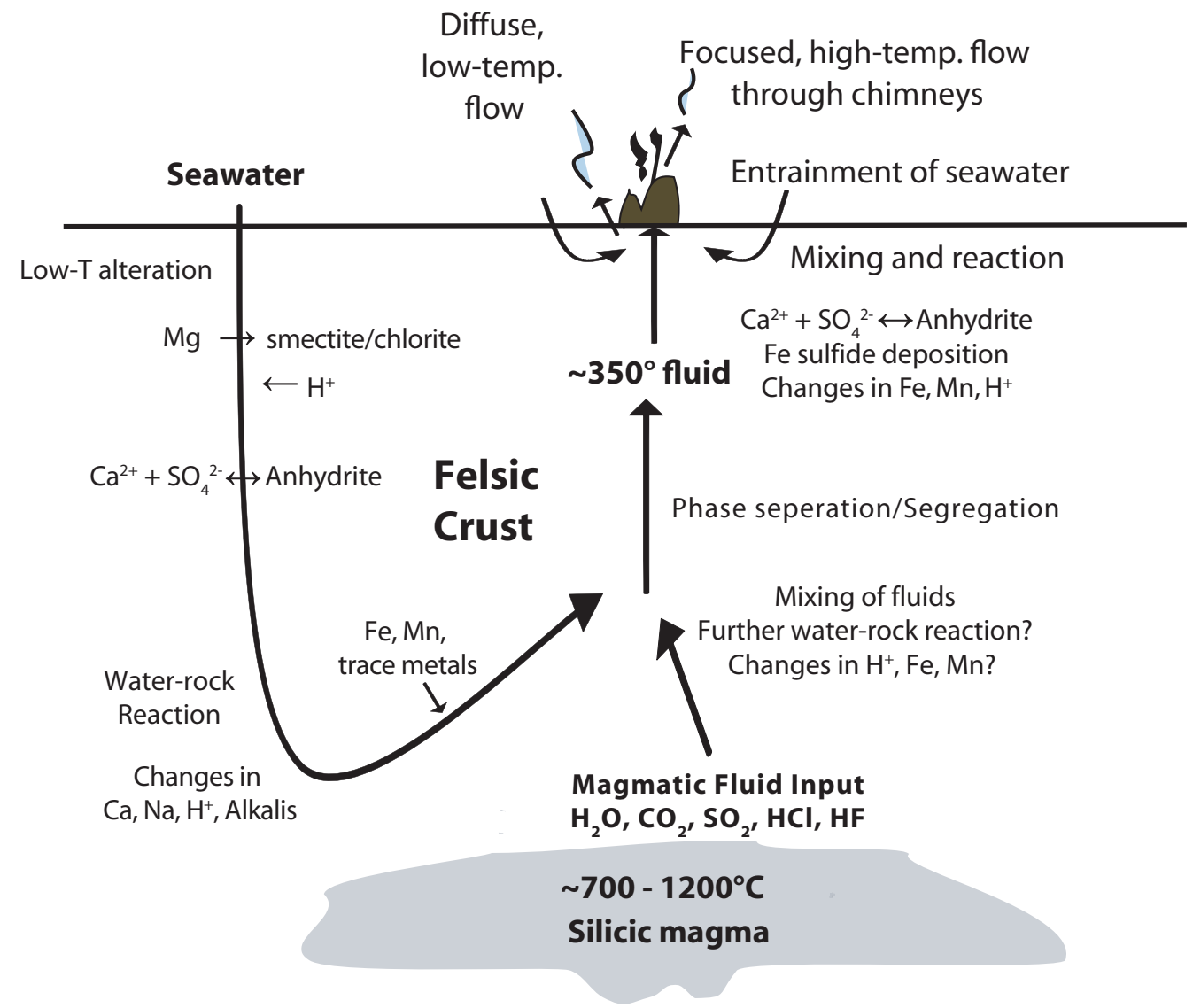

Figure 6.1. Cartoon showing the postulated evolution of fluids in a backarc hydrothermal system influenced by magmatic fluid inputs. The typical sequences of reactions taking place during 'recharge' in mid-ocean ridge systems occur, such as Mg-fixation and anhydrite deposition (ALT, 1995). Water/rock interactions in the 'reaction' zone will occur regardless of the presence of a magmatic fluid exsolved from silicic magma chambers. However, admixing of this fluid with evolved seawater-derived hydrothermal fluids complicates the history of fluid evolution if further water/rock interaction occurs. Phase separation can occur wherever the 2-phase boundary is intersected, either as a result of decompression during upflow or elsewhere in the system. Entrainment and admixing of seawater prior to venting of fluids at the seafloor further alters fluid compositions, leading to deposition of Fe sulfide minerals and admixed seawater-derived anhydrite. 


\section{REFERENCES}

ALT, J. C. (1995) Subseafloor processes in mid-ocean ridge hydrothermal systems. In: Seafloor Hydrothermal Systems: Physical, Chemical, Biological, and Geological Interactions, AGU Monograph, (Ed: S. E. Humphris, R. A. Zierenberg, L. S. Mullineaux, and R. E. Thomson), AGU Mongraph, 91, American Geophysical Union. pp. 85-114.

Bevington, P. R. and Robinson, D. K. (2003) Data Reduction and Error Analysis for the Physical Sciences. 3rd Ed. McGraw Hill.

HoriBE, Y. and CRAIG, H. (1995) D/H fractionation in the system methane-hydrogen-water. Geochimica Et Cosmochimica Acta 59(24), 5209-5217.

Proskurowski, G., Lilley, M. D., and Olson, E. J. (2008) Stable isotopic evidence in support of active microbial methane cycling in low-temperature diffuse flow vents at $9^{\circ} 50^{\prime} \mathrm{N}$ East Pacific Rise. Geochimica et Cosmochimica Acta 72(8), 2005-2023.

Proskurowski, G., Lilley, M. D., Seewald, J. S., Fruh-Green, G. L., Olson, E. J., LuPton, J. E., SYlVA, S. P., and Kelley, D. S. (2008) Abiogenic hydrocarbon production at Lost City hydrothermal field. Science 319(5863), 604-607.

Saccocia, P. J., Seewald, J. S., and ShanKs, W. C. (2009) Oxygen and hydrogen isotope fractionation in serpentine-water and talc-water systems from 250 to $450^{\circ} \mathrm{C}, 50 \mathrm{MPa}$. Geochimica et Cosmochimica Acta 73(22), 6789-6804.

SEEWALD, J. S. (2001) Aqueous geochemistry of low molecular weight hydrocarbons at elevated temperatures and pressures: Constraints from mineral buffered laboratory experiments. Geochimica Et Cosmochimica Acta 65(10), 1641-1664.

SuZUOKI, T. and EPSTEIN, S. (1976) Hydrogen isotope fractionation between OH-bearing minerals and water. Geochimica et Cosmochimica Acta 40, 1229-1240. 
WANG, Y., Sessions, A., NiElSEN, R. J., and GODDARD, W. A., III (2009a) Equilibrium ${ }^{2} \mathrm{H} /{ }^{1} \mathrm{H}$ fractionations in organic molecules: I. Experimental calibration of ab initio calculations. Geochimica et Cosmochimica Acta 73(23), 7060-7075.

WANG, Y., Sessions, A., NiElSEN, R. J., and GodDARD, W. A., III (2009b) Equilibrium ${ }^{2} \mathrm{H} /{ }^{1} \mathrm{H}$ fractionations in organic molecules. II: Linear alkanes, alkenes, ketones, carboxylic acids, esters, alcohols and ethers. Geochimica et Cosmochimica Acta 73(23), 7076-7086.

YANG, K. and SCOTT, S. D. (2006) Magmatic fluids as a source of metals in seafloor hydrothermal systems. In: Back-Arc Spreading Systems: Geological, Biological, Chemical, and Physical Interactions, (Ed: D. M. Christie, C. R. Fisher, S.-M. Lee, and S. Givens), AGU Monograph, 166, American Geophysical Union. pp. 163-184.

YANG, K. H. and SCOTT, S. D. (1996) Possible contribution of a metal-rich magmatic fluid to a sea-floor hydrothermal system. Nature 383(6599), 420-423.

YANG, K. H. and SCOTT, S. D. (2002) Magmatic degassing of volatiles and ore metals into a hydrothermal system on the modern sea floor of the eastern Manus back-arc basin, western Pacific. Economic Geology 97(5), 1079-1100.

YANG, K. H. and SCOTT, S. D. (2005) Vigorous exsolution of volatiles in the magma chamber beneath a hydrothermal system on the modern sea floor of the eastern Manus back-arc basin, western Pacific: Evidence from melt inclusions. Economic Geology 100(6), 10851096. 